

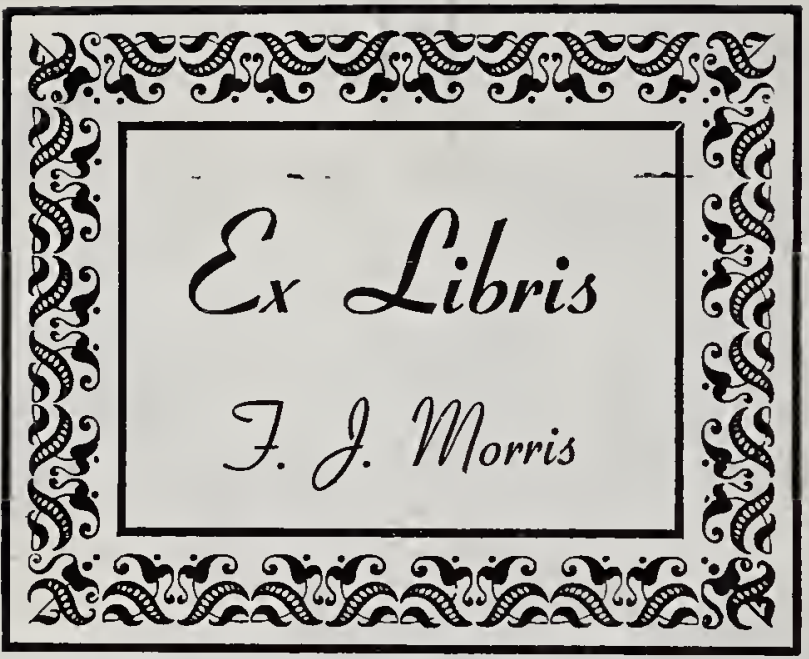


NUNC COGNOSCO EX PARTE

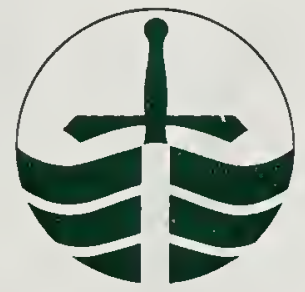

TRENT UNIVERSITY

LIBRARY

PRESENTED

IN MEMORY OF

F.J. Morris

by

Mrs. H.H. Graham 



\section{NATURAL HISTORY RAMBLES,}

\section{THE WOODLANDS.}

DY

M. C. COOKE, M.A. LL.D.

PUBLISIIED UNDER THE DIRECTION OF

TISE COMMITTEE OF GENERAL LITERATURE AND EDUCATION

AHPOINTED BY THE SOCIETY,FOR PROMOTING

CHRISTIAN KNOWLEUGE.

SOCIETY FOR PROMOTING CHRISTIAN KNOWLEDGE :

LONDON: 77, GELAT QUEEN ST., LINCOLN'S-INN FIELDS, W. . ;

4, ROTAL EXLHANGF, E.C. ; 48, PICCADILLY, W.

IND BY ALL BOOKSELLERS.

NEW YORK : POTT, YOUNG \& CO.

I879. 



\section{CONTENTS,}

CHAPTER.

PAGE.

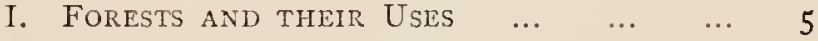

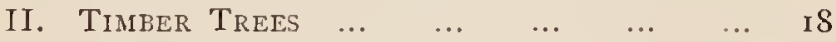

III. Smail Trees, Sitrubs, \&c. $\quad \ldots \quad$...

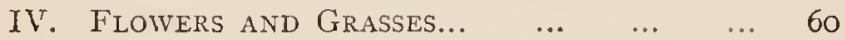

V. Ferns, Mosses, and Liverworts $\ldots$... 80

VI. FUNGI AND LICHENS $\ldots$...

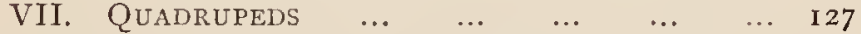

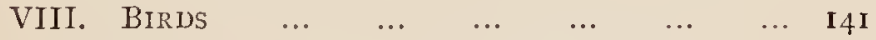

IX. BeEtles $\ldots$...

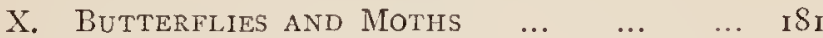

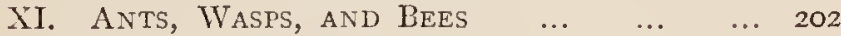

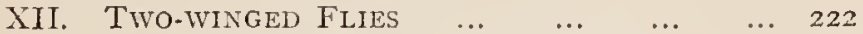

XiII. Plant.bugs, Aşphides, and Scale... ... 231

XIV. DRAgon-Flies AND Other. INSECtS ... ... $24 \mathrm{I}$

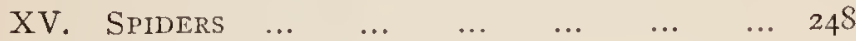

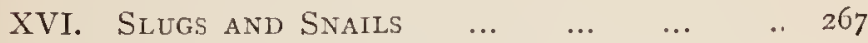

XVII. Galls and Parasites ... $\quad \ldots \quad \ldots \quad \ldots \quad \ldots \quad 276$ 
Digitized by the Internet Archive in 2019 with funding from Kahle/Austin Foundation 


\title{
THE WOODLANDS.
}

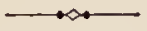 \\ CHAPTER I.
}

FORESTS AND THEIR USES.

Frow that remote period when Adam and his companion walked "amongst the trees of the garden," down to these latter days, men have exhïited their attachment to trees, woods, and forests. Some of the earliest rites of idolatry were performed under the shelter of trees. In all the worships of the world they have been an important adjunct. The sculptures of India, Assyria, and Egypt, represent trees as associated with religious rites; and the aisles of our own splendid cathedrals exhibit semblances of vistas of stately trunks hewn in stone, the branches of which meet in arches overhead.

Religiously, poetically, historically, man is associated with forests, his first home, his first temple; and even now his natural instincts lead him, whenever the cares and business of life permit of relaxation, to seek a ramble in the woods as a welcome relief. To know something of the multitudinous objects with which the woodlands teem is a reasonable desire that accompanies his wanderings, and such a silent com- 
panion as he longs for, it is the object of this little volume to supply. Together, the wanderer and his mentor, thus introduced, will henceforth gossip together over their favourite theme.

Going backwards to early English history we discover that these islands were noted for their woodland character; for their numerous forests, of which remains are still in existence. As cultivation has extended, population increased, and with it a greater demand for timber, the old forests have gradually diminished. We still retain the names and traditions of the New Forest, Dean Forest, Whittlebury, and Salcey Forests; Alice Holt, Woolmer, and Bere Forests ; Wychwood, Hainault, and Epping ; Windsor, Delamere, and Sherwood, in England ; not to mention the old pine forests of Scotland, and others, north and south, of which the names alone are left.

Cæsar says, "what the Britons call a town, is a tract of woody country, surrounded by a high bank and a ditch, for the security of themselves and cattle against the incursions of their enemies; " and Strabo remarks that "the forests of the Britons are their cities; for when they have inclosed a very large circuit with felled trees, they build within it houses for themselves, and hovels for their cattle." Thus the early records of the Briton associate him with a love for trees and woods.

Gradually, but continually, during the past thousand years, the original forests have diminished; partly to furnish timber for houses and ships, partly being enclosed and brought under cultivation, but chiefly to meet the wants of a rapidly increasing population. 
On the other hand, fruit-trees, in orchards and gardens, large parks with ornamental trees, young plantations, and other forms of vegetation, having to a large extent replaced the forests, less disastrous consequences have followed their diminution than have resulted in many other countries, as for example in Spain, as well as some portions of France.

Forests, which are distributed so universally over the surface of the globe, and are recklessly destroyed in newly-colonized countries, without regard to consequences, have important functions to perform in the economy of nature. It is only in most recent times that man has awakened to the consciousness, that in the wholesale destruction of forests the entire aspect of a country is changed, equilibrium disturbed, and the advent of desolation threatened. The destruction of forests in the Island of Cyprus, in order to furnish its celebrated timber to the Romans, Jews, and other nations, has reduced a paradise to a comparative wilderness; and the progress of similar destruction in India aroused the Government to adopt a complete system of forest conservancy in order to avert the threatened evil.

Humboldt, the great traveller, could not fail to observe the influence of forests on the climate of a country, and consequently we find him urging in lis. writings attention to this subject. "By felling the trees which cover the tops and the sides of mountains," he says, "men in every climate prepare at once two calamities for future generations; want of fuel and scarcity of water. Trees, by the nature of their perspiration, and the radiation from their leaves in a 
sky without clouds, surround themselves with an atmosphere constantly cold and misty. They affect the copiousness of springs, not, as was long believed, by a peculiar attraction for the vapours diffused through the air, but because, by sheltering the soil from the direct action of the sun, they diminish the evaporation of water produced by rain. When forests are destroyed, as they are everywhere in America by the European planters, with imprudent precipitancy, the springs are entirely dried up, or become less abundant. The beds of the rivers, remaining dry during a part of the year, are converted into torrents whenever great rains fall on the heights. As the sward and moss disappear with the brushwood from the sides of the mountains, the waters falling in rain are no longer impeded in their course; and instead of slowly augmenting the level of the rivers by progressive filtrations, they furrow, during heavy showers, the sides of the hills, bearing down the loosened soil, and forming sudden and destructive inundations. Hence it results, that the clearing of forests, the want of permanent springs, and the existence of torrents, are three phenomena closely connected together. Countries situated in opposite hemispheres, as, for example, Lombardy, bordered by the Alps, and Lower Peru, inclosed between the Pacific and the Cordillera of the Andes, afford striking proofs of the justness of this assertion."

"That this is not a mere sentimental complaint on the part of a great naturalist, grieving over the destruction of forests, may be proved by reference to India, and the famines which appear periodically in certain 
districts. Sir Richard Temple, reporting to the Government, in consequence of the famine of 1877 , laments the continued destruction of forests. "In the midst of cultivated tracts there are to be seen bare sterile hill-sides, said to have been forest-clad within living memory. In such localities the climate is supposed to have changed for the worst. Beyond the Ghat Mountains, in Bellary and Kurnool, the treeless, shrubless aspect of the country is as wonderful as it is melancholy. These are the very districts where famine has been occasionally epidemic, and where scarcity has been almost endemic. Any thoughtful spectator must perceive that, according to all meteorological experience, and to the almost certain teaching of proved facts, these fine districts were not destined by nature to be the prey and sport of famine and scarcity, but have been rendered subject to these calamities by the thoughtless action of man."

Not only does the destruction of forests alter the climate, diminish permanent springs, render inundations common, but it consequently reduces productive cultivation, and is the forerunner of scarcity and famine. These are not, by any means, all the disasters which may be traced to this source. Numerous instances are recorded in the Government records in support of the theory that cholera, one of the greatest scourges of the East, increases as trees diminish. The road to Sambalpoor runs for sixty or seventy miles through forest, sometimes very dense; nevertheless, on this route, traversed daily by hundreds of travellers, vehicles, and baggage trains, cholera rarely appears, and when it does appear it is of a mild form. 
But when we come to the road from Arang, which runs for about ninety miles through a barren treeless plain, cholera appears every year in its worst form, the dead and dying lying by the wayside, and trains of vehicles, half of whose conductors are dead. Similar testimony is given by medical officers of barracks surrounded by trees, in which the inmates were almost exempt from sickness, whilst in those exposed to the full influence of the wind, without any trees, cholera was prevalent. Dr. Bryden states that in the villages of the almost treeless district of Rajpoor sixty or seventy per cent. of the inhabitants are sometimes swept away by cholera in three or four days, while the wooded district of Sambalpoor is often free from it, or it is not there severe. These facts, it is true, relate to a tropical country, remote from home, but they serve to illustrate the theory here advanced that the presence of trees is important to the well-being of man, and that the destruction of forests is in many ways detrimental.

In connection with this subject it may be remarked that Ebermeyer has shown that the "temperature of the trees in a forest, and even in the tops of them, is always lower than the air in the forest. 'The shade of a single tree, therefore, cools, not only by intercepting the sun's rays, but also by the effect of gentle fanning. The shelter of a thick wood, however, is much more agreeable than that of a single tree. The air in a wood is cooler than that of an open space exposed to the sun. The air from outside is drawn into the wood, is cooled by it, and cools us again. And it is not only the air that cools us, but the trees them- 
selves. Observation has shown that the trunks of trees in a wood, breast high, even at the hottest time of the day, are five per cent. cooler than the air."

This is sufficient for the direct evidence of the influence of trees on climate, water, cultivation, famine, and disease, but there are also collateral aspects which present themselves to the naturalist, to which the economist pays little attention. He sees in the destruction of trees a great disturbance of the equilibrium of animal life; with the absence of woodlands he takes cognizance of the absence of all forms of life which depend upon trees for their existence. $\mathrm{He}$ contemplates a depauperized flora and fauna. Whole genera disappear, and sometimes the individuals of certain species increase to an enormous extent, until the artificial conditions, produced by an interference with the harmonjes of nature, become merged into a new equilibrium in accordance with the new conditions.

No other class of animals is connected so closely with the vegetable kingdom as insects; very many of them are not only destined to feed upon vegetables, but even upon certain definite species or genera of plants. "From this," writes Schouw, "it will readily be concluded that forests are of great inıportance to insects. Myriads of these little animals live upon and in the trunks of trees, upon their leaves, flowers, fruits, and upon their parasitical plants; myriads of others live upon the vegetable feeders. In temperate zones the number of insects is smaller than in the tropics, but nevertheless large enough, so that particular species of insects sometimes destroy great tracts of forest; 
for example, those which bore into the trunks of coniferous trees, or eat off their buds, as has been done by the larve of a little beetle (Bostricinus), and of a moth, in the Hartz Forests.

It is well known to entomologists of our own country how the great reduction or extirpation of a foodplant has resulted in the disappearance of the insect which fed upon it. In a similar manner that the reclamation of fenny districts has caused many insects almost entirely to disappear.

Next in importance to the insect world in the forests is the feathered tribe. The climbing-birds, especially fitted by the structure of their feet to live upon trees, are particularly numerous among the winged inhabitants of forests; in the tropics it is the parrots, in the temperate zone it is the woodpeckers, who are the chief of the climbers which inhabit the woods; the grubs, which they find in the trunks of the trees, forming their food; but very many of the family of the song-birds have their home here.

Reptiles are less abundant, and less connected with the forests. Just as the birds have a peculiar forestfamily in the parrots, so also the mammals have one in the monkeys. Among other animals in temperate countries are smaller beasts of prey. Lastly, the human race; we see that nations in the lowest stage of development are sometimes closely connected with forests. At length civilization comes into hostile contact with the forests, and thus, other conditions being equal, the country in which civilization is oldest possesses the fewest woods. Forests are more sparingly met with in the countries of the Mediterranean 
than northward of the Alps, and more sparingly in the centre than in the north of Europe. But enough of this.

A woodland ramble is an enjoyable recreation at

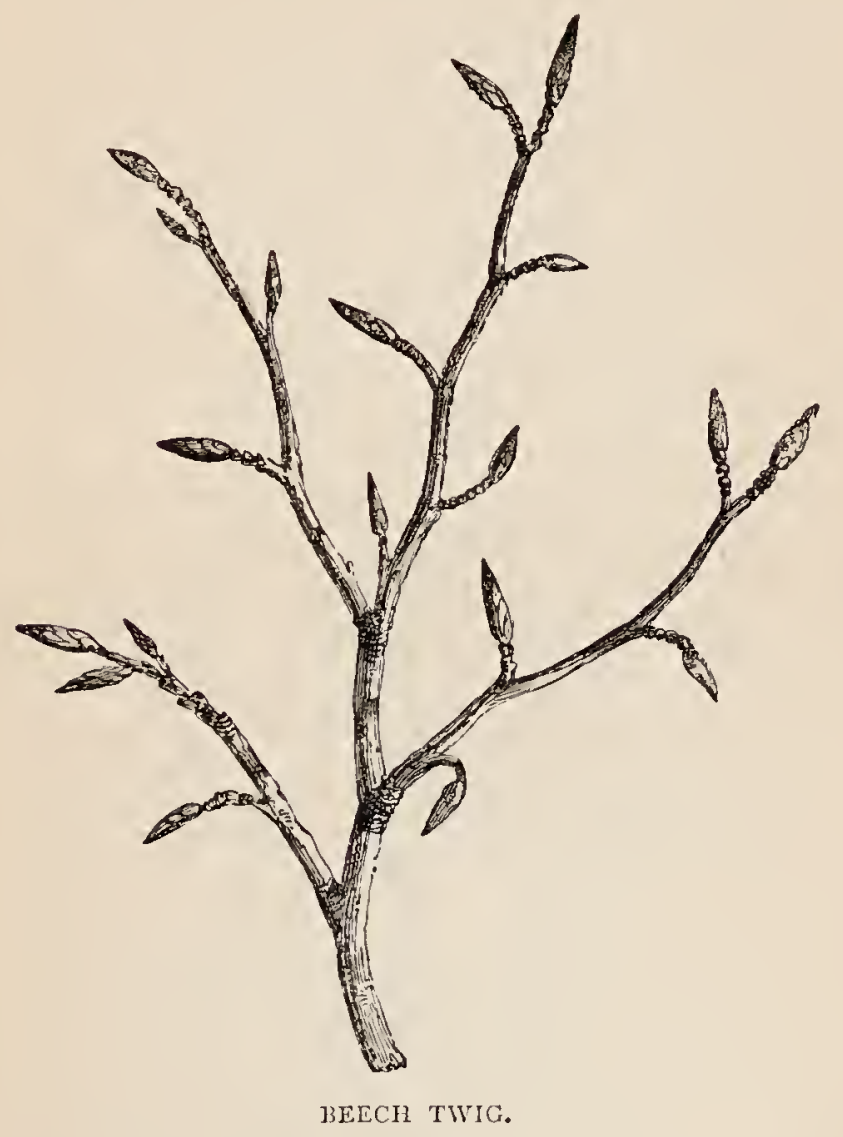

all periods of the year. There is a beauty and a charm which is peculiar to each season, and something new may be learnt at all times. It is comparatively casy, 
for instance, to determine every tree in summer and autumn when there are leaves to guide us, but in the winter new aspects are encountered, and then it becomes a good exercise to determine trees by their aspect, habit of growth, ramification, angular incidence of the branches; appearance of the bark ; and thus, as it were, determine its name from its skeleton. In the spring another exercise awaits us; it is the determination of trees from the form and arrangement of the young buds. Some are opposite to each other, some are alternate, some are much elongated, others are short and obtuse. A little study and practice will soon enable any one to determine one twig from another, and refer each to its proper tree.

The arrangement of the buds around a twig follows in each species a uniform plan. If we take a beech twig, for instance, we shall observe that the buds are produced in two opposite rows, so that they occur alternately on opposite sides of the twig. The first, third, and fifth being over each other on one side, and the second, fourth, and sixth on the other. If we draw a line from any given bud spirally round the twig, so as to pass through three consecutive buds, we shall find when it has reached the third bud it is directly over the point whence it started, has made one turn of a spiral passed from one bud, through a second, and ended at the third. This is a simple arrangement of alternate buds. Let us take the alder, and starting in the same manner from a given bud, draw a line spirally through all the buds above it until the line terminates at a bud directly over that from which the spiral started. In this instance the 
fourth bud will be over the first, and the spiral has made one revolution. Now, examine an oak twig in the same manner, and the sixth bud will be found directly over the first; but to reach this the spiral will make two revolutions instead of one; no bud within one revolution of a spiral occurring just over the starting point. In the same manner a willow twig being examined, it will be seen that the spiral makes three convolutions before a bud is reached which is directly over the first, and the number of buds included in the series is eight. Such an exercise will give zest to a winter or early spring walk in a wood, and at the same time become a source of instruction. In order to facilitate the recording of such observations a fractional method is adopted, the number of convolutions of the spiral representing the numerator, the number of buds encountered being the denominator. Thus, the beech is $\frac{1}{2}$, the alder $\frac{1}{3}$, the oak $\frac{2}{5}$, the willow $\frac{3}{8}$, \&c. The ash and horsechestnut, and some other trees, have the buds in pairs opposite to each other, and the arrangement is commonly that of the simple alternation of pairs. As a matter of course the leaves of the same trees will follow the same plan, and may be studied in the same manner.

Although it is difficult to find two leaves on the same tree so exactly alike that they cannot be distinguished from each other, yet the general outline, or contour, will always be found to follow a particular type, the veins will diverge at a given angle, and fallen leaves may, without any great difficulty, be referred, after a little practice, to the kind of tree to 
which they belong. This exercise will also furnish young persons with occupation during a winter walk, and one which may afterwards prove of considerable service should their tastes lead them to the study of the parasites of leaves.

A curious theory was once propounded, that the primary veins of a given leaf diverge from the mid-rib at the same angle as the branches of the parent tree diverge from the stem. That in all trees there is a coincidence of angle at which the primary veins, branches, and roots diverge. This was probably more fanciful than true, since the incidence is not often uniform in the same tree.

We do not doubt that all persons, but especially those who habitually reside in towns, enjoy an occasional ramble through the woods; without any specific object beyond the enjoyment of its scenery, its atmosphere, or its music, such an occasional ramble will afford pleasure; but, if we add to this inducement something which shall call forth the powers of observation, how much more enjoyable the ramble becomes. It matters little what the particular object may be which leads a person habitually to take a woodland ramble, so long as it is something which leads him to use his eyes, keeps his mental faculties in exercise, and furnishes some material for afterthought. A simple walk through a wood or a green lane, as an expedient for killing time, must always prove unsatisfactory, and yet the feat is acconplished every day. Iet those who would really and thoroughly enjoy a woodland stroll undertake it with some definite object, and they will find, not only that the 
time passes too rapidly away, but that weariness comes less speedily; and the subsequent reflections will, in a measure, repeat the enjoyment when the stroll cannot be repeated. One person will go through a wood who has a great love for birds; he will watch all their movements, study their notes, observe their habits, and return home on every occasion with some new experience, some pleasant reminiscence of his stroll. Another has a fancy for collecting galls, and rearing the insects they contain, for studying their economy, and seeking to unveil the mystery which enshrouds these curious productions. Yet another, deeming, perhaps, that a collection of moths or beetles would afford more instruction than a collection of postage-stamps, has this object in view during a woodland ramble. In each case there is some definite object for which the walk is projected, there is some purpose for which the powers of observation must be cultivated, and the result will be that additional knowledge will be gained, consequently additional material stored up for subsequent reflection.

In the following pages a brief outline, which some will think far too meagre, is given of the various objects, or classes of objects, which are to be encountered in woodlands. All that such a wor's can hope to accomplish is to arouse a desire to cultivate a better acquaintance with the objects to which a passing allusion is made. The moral of such a volume can only be, "Select your hobby and pursue it!" 


\section{CHAPTER II.}

TIMER TREES.

THE vegetation of woodlands may, for the sake of convenience, be arranged in four groups. The first group would consist of the large timber trees which constitute the wood or forest. These, in some instances, are chiefly of one or two kinds, as oak woods, beech woods, or fir woods; but in the majority of cases they are much more mixed, and consist of several species growing together. The second group consists of smaller trees which compose the undergrowth, and shrubs which never attain the dignity of trees. The third group will be the herbaceous vegetation, mixed with dwarf perennials. Whilst the fourth group will include what are botanically called cryptogams, such as the ferns, mosses, liverworts, lichens, and fungi. It will be advisable to treat of this vegetation under these four groups, giving examples of each, without attempting to enumerate all; and as the arrangement is purely an artificial one, at least in so far as the first three groups are concerned, it must not be subjected to too critical a 'est.

Much might have been written of the uses to which 
each kind of timber has been applied, the economic application of the bark and other portions, the trees of each species remarkable for their size, age, or historical associations; but all this has been so admirably done already in a volume entitled the "Forest Trees of Great Britain," I that it may be omitted with advantage.

The $\mathrm{OAK}^{2}$ is the "king of the forest," and is common in all our woodlands and parks. Some persons are of opinion that what we term the "oak" consists of two species, others that these are only well marked varieties. The distinctions are that in the pedunculate form the leaves have very short footstalks, and the stalks of the fruits are much elongated. The buds. on the young wood are not prominent. In the sessilefruited form the leaves have long footstalks, the fruit is seated close to the branch, and the buds on the young wood are prominent. What, however, is of still greater importance is, that the timber of the sessile-fruited form is very greatly inferior to that produced by the stalked-fruited or pedunculate form. In the days of wooden ships our "three-deckers" were built of oak; and a curious calculation is made in Brown's "Forester" as to the quantity of oak which was requisite to construct a first-class " man-ofwar." "It takes fully one hundred and fifty thousand cubic feet of timber to build a seventy-four-gun ship; and allowing upon an average that the trees in an oak forest, when arrived at maturity and ready for shipbuilding, stood at the distance of about thirty feet.

1 Published by the S. P. C. I.

2 Quercus robur.

C 2 
from each other, we could only have about fifty trees from an acre; and supposing that the same trees were from one hundred to one hundred and twenty years old, there would probably be about seventy feet of timber in each at an average: consequently, we see from this calculation, which is pretty near the truth, that no less than the matured crop of forty-four acres of woodland, or two thousand two hundred fullgrown trees, are required for one such ship." This relates, however, to the past, as iron and steel have superseded wood in naval construction.

A volume of gleanings might speedily be compiled of stories, legends, and wonderful trees of this species, for there is no other in which the Englishman has so great a pride. The Britons regarded it as a symbol of their god of thunder. 'The Yule-log, bumt at Christmas in honour of their deities, was always of oak. The Druids are said to have worshipped under an oak, and to have offered sacrifices in wicker baskets of oaken twigs. Criminals, we are told, were tried under an oak tree. The Saxons held their national meetings under an oak. The celebrated conference of the invading Saxons and the Britons was held under the oaks of Dartmoor. King Arthur's round table was made of its timber; so was the cradle of Edward III., in order to conciliate the Welsh. And it was considered unlucky to cut down a celebrated tree, for Evelyn gravely relates of two men who cut down the vicar's oak, that the one lost his eye, and the other broke his leg soon afterwards.

Remarkable oak trees are more numerous than 
those of any other species. Foremost is, or was, that of Herne the hunter, who, as Shakspeare says,

"Doth all the winter time, at still midnight,

Walk round about an oak, with great ragged horns, And there he blasts the tree."

Then we have King's oak, Abbot's oak, Pope's oak, Chenies oak, Flitton oak, Damory's oak, Fairlop oak, Merton oak, Chandos oak, Yardley oak, and we know not how many more, to all of which there "hangs a tale"; but we must leave all these,-

"Whose boughs are moss'd with age

And high top bald with dry antiquity," -

and pass from the monarch to his humbler courtiers, which are, in all respects, subsidiary, but not wholly unworthy companions.

The AsH ${ }^{1}$ is a native of Britain, and one of our most useful trees. The leaves are compound; that is, each leaf consists of five or six pairs of leaflets placed opposite to each other, along a central leafstalk. In habit the tree is disposed rather to grow tall than stout, so that in plantations and close woods the trunk is thin, but in parks and open lawns it becomes a large and imposing tree.

The duration of the ash is considerable, there being instances in Scotland of trees nearly three hundred years old, and many upwards of two hundred years retain their health and vigour.

It was well known to the ancients, for Homer celebrates the mighty ashen spear of Achilles, and Virgil,-

"The towering ash is fairest in the woods."

1 Fraxinus excelsior. 
In the Edda the council of the gods is said to be held beneath the sacred ash, whose branches cover the surface of the world,

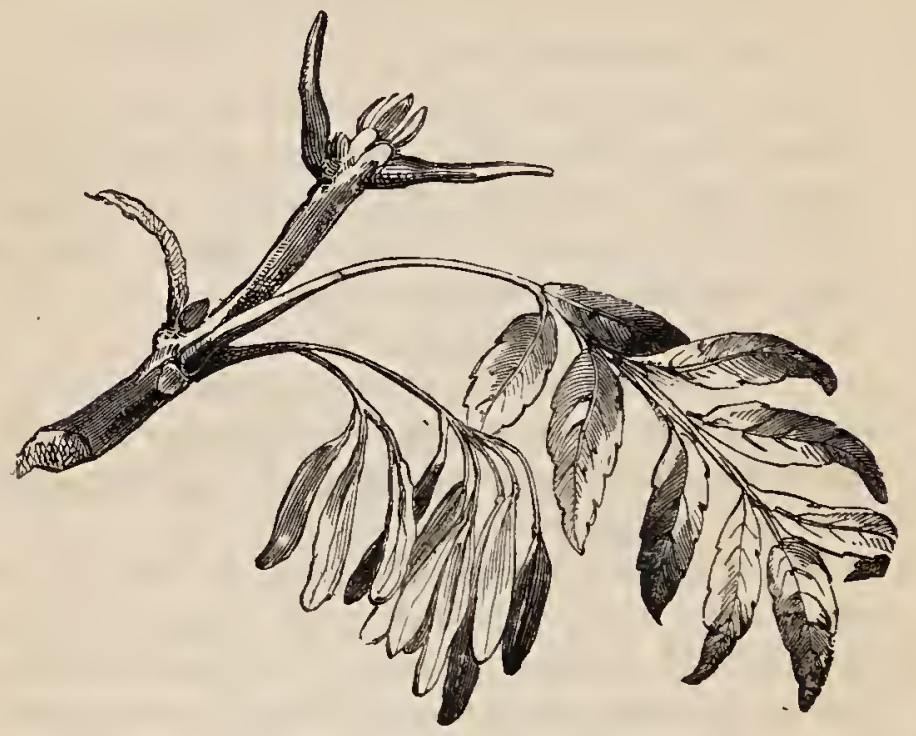

ASH SEED-VESSELS.

Large trees of this species have been recorded. Dr. Walker says that he measured the trunk of a dead ash in the churchyard of Lochaber which was fiftyeight feet in circumference at five feet from the ground; and at Domrey, near Clare, in Galway, an ash stood a few years since forty-two feet in circumference at four feet from the ground.

A curious circumstance is related by Dr. Plot of an ash key (or winged seed, so called) rooting itself on a decayed willow, and finding, as it increased, a deficiency of nourishment in the mother plant, it began to insinuate its fibres by degrees through the trunk 
of the willow into the earth. There receiving an additional sustenance it began to thrive, and expand itself to such a size that it burst the willow in pieces, which fell away from it on every side; and what was before the root of the ash being now exposed to the air became the solid trunk of a vigorous tree.

The ELM ${ }^{1}$ is a large timber tree, seen to perfection in the valley of the Severn. It is generally admitted to be one of the finest of our trees for park scenery. It grows tall and erect, without any great tendency to spread, and attains a height of eighty feet in as many years. The leaves are dark green, ovate, with a doublytoothed margin and a rough surface. At the base, where the lamina joins the short petiole, it is unsymmetrical, one side extending lower down, and being, more rounded than the other. The seeds are bordered by an oblong membraneous

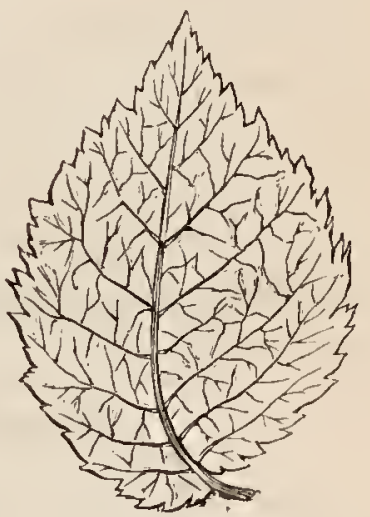

ELM LEAF. wing, which is deeply cleft at the apex, but they seldom ripen in England.

This tree is rarely cultivated in Scotland, where the wych elm is preferred, but in England it forms a prominent object in every landscape.

The elm was a funereal tree with the ancients, and it is a curious fact that the wood is still in much repute for coffins. The imperial city of UIm (Ger-

1 Ulmus campestris. 
many) derives its name from the number of elms which grow in its vicinity.

The large dimensions to which the elm will attain may be judged from one mentioned by Ray, which was felled in Staffordshire, one hundred and twenty feet in length, and seventeen feet in diameter. When sold its head produced forty-eight waggon loads of firewood ; and its trunk, besides sixteen blocks, furnished eight thousand six hundred and sixty feet of planks, the whole mass being estimated at ninetyseven tons.

The use which the Romans made of the elm as a support to the vine has given rise to numerous allusions by poets, ancient and modern; from Orid,-

"Or, if that vine without her elm should grow 'T would creep, a poor neglected shrub, below,"-

to Milton, describing the occupations of Adam and Eve,--

\section{"They led the vine}

To wed her elm." .

The Wrch Elml is a native of Scotland, where it supplies the place of the English elm. It is a much more spreading tree, with strong divergent limbs. The leaves are larger than in the English species, with a longer point, but like them are rough, and unequal-sided at the base.

In many parts of the country the wych elm, or witch hazel, is considered a preservative against witches. In some of the midland counties Loudon says that a little cavity is made in the churn to receive

1 Ulmus montana. 
a small portion of witch hazel, without which the dairymaids imagine that they would not be able to get the butter to come.

Gerard tells us that when long bows were in use there were very many made of the wood of this tree, for which purpose it is mentioned in the English statutes by the name of witch hasell.

The Tutbury wych elm, described and measured by Strutt, had a trunk sixteen feet nine inches in circumference at five feet from the ground. An elm called the Trysting Tree, at Roxburgh, in Teviotdale, was measured in r796, and its girth at four feet from the surface of the ground was thirty feet. There are still large trees of this species in Scotland, though not attaining the above recorded dimen-

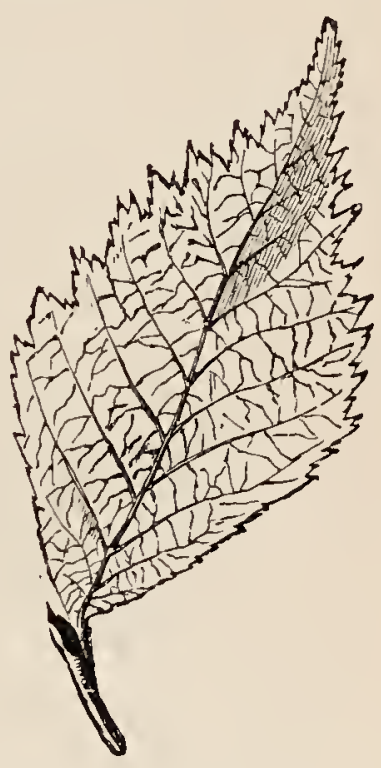

LEAF OF WYCH ELM. sions.

In a note to "Brand's Antiquities" the derivation(?) of "witch" is thus given. "Witch is derived from the Dutch 'witchelen,' which signifies whinnying and neighing like a horse; in a secondary sense, also, to foretell and prophesy; because the Germans, as 
Tacitus informs us, used to divine and foretell things to come by the whinnying and neighing of their horses."

The $\mathrm{BEECH}^{\mathrm{l}}$ is a very common English tree, and equally common in a dwarf condition for hedges. It is easily known from other trees in a park by its smooth bark, and light green leaves. The latter are ovate, and scarcely perceptibly toothed at the margin, smooth, with the veins parallel to each other, and proceeding direct to the edge of the leaf. When quite young a delicate silky fringe can be distinctly seen surrounding the margin, but this almost vanishes from old leaves. Very often the dead leaves of the beech may be seen still clinging to the branches in the depth of winter, and this is especially the case in beech hedges. Old trees do not exhibit this peculiarity. It may usually be observed that the ground beneath beeches is very bare, few herbs or grasses caring to grow under its shadow. The triangular, sharp-cornered nuts of the beech are enclosed within a hard, tough involucre, which divides into four spreading lobes, which diverge, and allow the seeds to escape.

The finest beeches in Britain are said to grow in Hampshire, and there is a curious legend of those in the Forest of St. Leonard. This forest, which was the abode of St. Leonard, abounds in noble beeches, and the saint was particularly fond of reposing under their shade,-

"Tityre, tu, patulæ recubans sub tegmine fagi." 
When he did so he was annoyed during the day by vipers, and at night by the singing of the nightingale. Accordingly he prayed that they might be removed, and such was the efficacy of his prayers, that since that time, in that forest,

"The viper has ne'er been linown to sting,

Or the nightingale e'er heard to sing."

The Sycamore ${ }^{\mathrm{l}}$ is generally known in Scotland as the plane, but the true plane-tree is not indigenous, having been introduced from the Levant. The sycamore grows to a considerable size, and attains a great age. The leaves are as broad as long, deeply divided into five lobes, and seated on long foot-stalks. The seeds are produced in what is termed a samara, two being united at the base, and the wings spreading like a V.
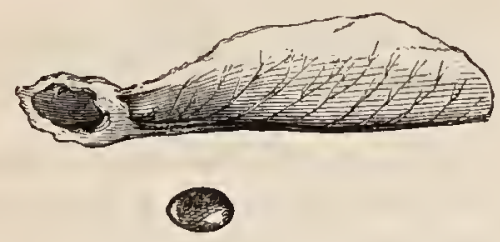

WINGED SEED-VESSEL OF SYCAMORE.

A sycamore in the park of Scone Palace, in Perthshire, is said to have been planted in the time of Mary Queen of Scots. Although three hundred years of age it is still in perfect health. Another at Arniston House, not more than sixty-five feet high, contains three hundred cubic feet of timber, and is said to be at least two hundred years of age. 
The sap of this tree contains sugar, and experiments have been made from time to time to obtain a kind of sugar by evaporation. Sometimes an ounce of sugar has been obtained from a quart of sap, but the proportion varies. This sap has also been converted into a kind of wine. In Scotland it is stated that the children amuse themselves by cutting openings in the bark, and sipping the sap that flows from the wounds.

The sycamore tree on which Zaccheus climbed to see Christ pass on his way to Jerusalem was not this tree, but the sycamore fig, which latter is the tree intended in all Scriptural references to the "sycamore." The bright autumnal tints which the leaves rapidly assume are alluded to by Cowper in the lines,-

"The sycamore, capricious in attire;

Now green, now tawny, and ere autumn yet

Has changed the woods, in scarlet honours bright."

The Planel is one of the most common trees in the parks and open spaces in London and its neighbourhood, and may easily be recognized in winter by its habit of shelling off the outer coating of the bark. The leaves somewhat resemble in form those of the sycamore, but the foot-stalks are shorter. The globose catkins, pendulous on long stalks, which are for some time persistent on the trees, are sufficient to distinguish the planes from the sycamore, or any of the maples. This tree grows to the height of seventy 
feet, or more, with wide-spreading branches, is highly ornamental, and fortunately seems to thrive well amidst the busy haunts of men.

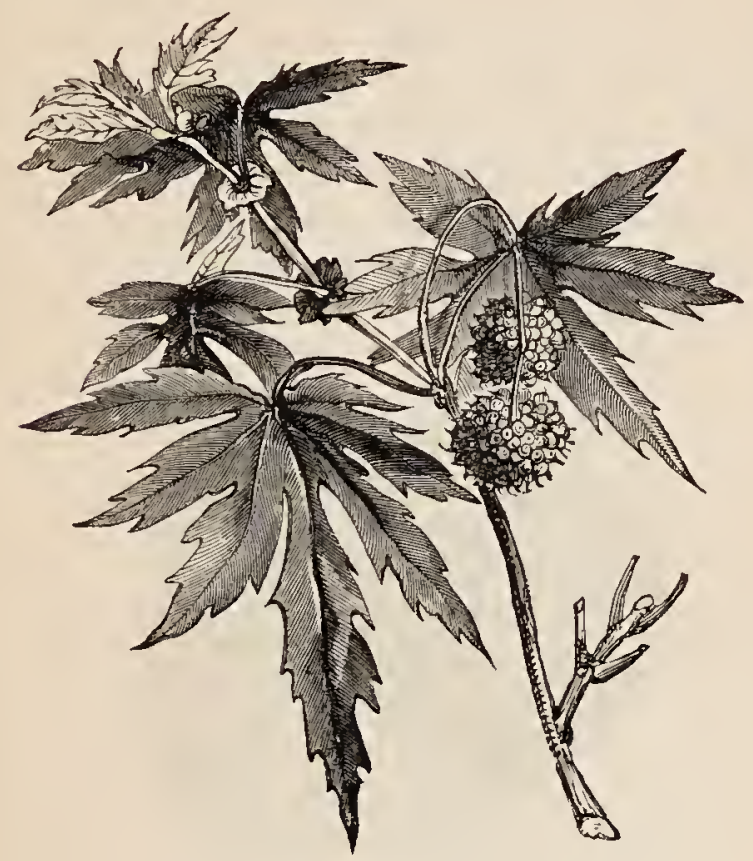

PLANE LEATES AND FLOWERS.

Herodotus says that Xerxes, when he invaded Greece was so enchanted with a beautiful plane tree which he found in Lycia that he encircled it with a collar of gold, and confided the charge of it to one of the ten thousand. Pliny relates that a governor of Lycia feasted eighteen persons in the hollow of a plane tree in that province.

The Oriental plane was introduced into England 
about the middle of the sixteenth century. One of the oldest trees was recently to be seen at Lee Court, in Kent; this tree was mentioned by Evelyn, in 1683 , as one of the oldest introduced into this country. It is one of the few trees which does not appear to be injuriously affected by the smoke of our large cities, hence it is one of the most common and healthy of the trees in and around London. The American plane $\mathrm{e}^{1}$ is less common in Britain, but is very similar in its general appearance.

The BLACK PoPLAR ${ }^{2}$ is a rapidly growing tree of

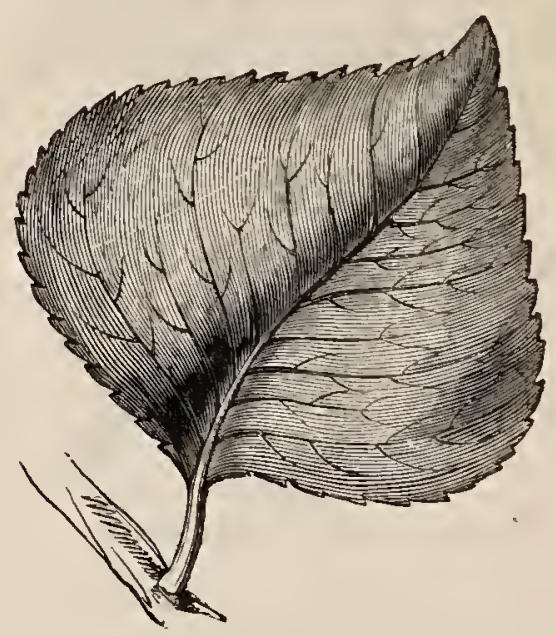

LEAF OF BLACK POPLAR.

very doubtful value. It will reach considerable dimensions in a very short time, and is supposed to attain its best condition in about fifty years. The

1 Platanus occidentalis.

2 Populus nigra. 
leaves are nearly triangular, with the lower angles rounded and the upper angle pointed, smooth on both sides, seated on rather long foot-stalks. The margin of the leaves is bluntly toothed.

According to Ovid, when Phaethon borrowed the chariot and horses of the sun, and by his heedless driving set half the world on fire, he was hurled from the chariot by Jupiter into the Po, where he was drowned; and his sisters, the Heliades, wandering on the banks of the river, were changed into trees. Some authors believe these to have been "black poplars," which are now abundant on the banks of that river.

"And eke those trees, in whose transform'd hue The Sun's sad daughters wail'd the rash decay Of Phaethon, whose limbs with lightnings rent, They gathering up, with sweet tears did lament."-

(Spenscr.)

The leaves of this, as well as the Aspen, and indeed most of the poplars, have long and slender footstalks, so that they wave and flutter with the slightest draught of wind. This has afforded many a happy allusion for the poets, from the time of Homer down to modern days; one Spanish poet compares the tree io his lady's hair,--

"Each wind that breathes, gallantly here and there Waves the fine gold of her disordered hair, As a green poplar leaf in wanton play Dances for joy at rosy break of day."-(Garcilasso.)

The ABELE, ${ }^{3}$ or white poplar, is generally a small 
tree, which may be known at a considerable distance by the whiteness of its foliage. The leaves are rather triangular, with irregular lobes and teeth, a difficult form of leaf to describe in writing within a few words. The under-side of the leaves is covered with a densy coating of matted white down. Like the black poplar, this tree loves a damp situation, where it grows rapidly, but is seldom seen of any great size.

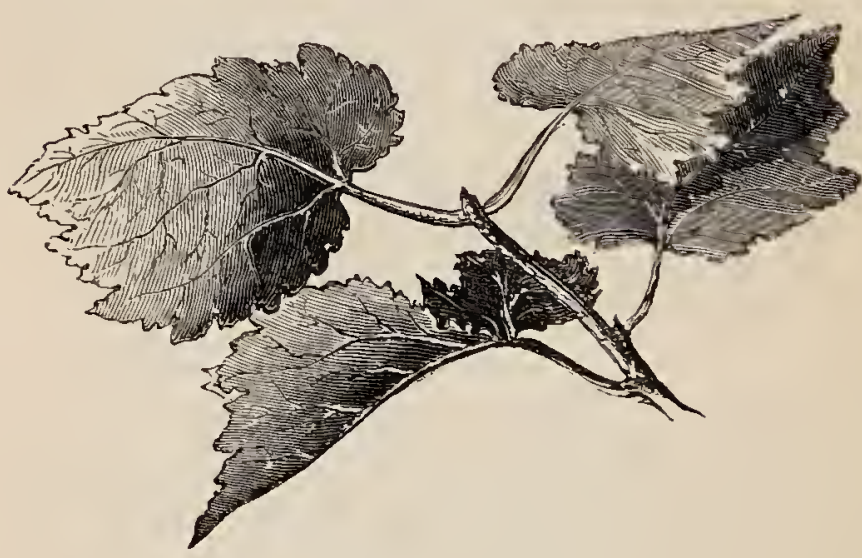

LEATES OF WHITE POPLAR.

It is generally supposed not to have been a native of Britain, but was introduced from Flanders. In a work published in 1659 it is stated that ten thousand abeles were at once sent over to England from Flanders, and transplanted into many counties. Evelyn mentions the "abeel" as "of late much transported out of Holland." This tree was known to the Romans and Greeks, and was consecrated to Hercules. It is 
also frequently mentioned by Homer and Horace. Simoisius, when killed by Ajax, is compared in the Iliad to the fall of a poplar :-

"So falls a poplar, that in watery ground

Raised high its head, with stately branches crown'd"

In France this tree is so abundant in some of the forests as to form the prevailing tree over large tracts of country, furnishing fuel to the neighbouring towns. It is stated that in Paris the bakers' ovens are almost entirely heated with the wood of this tree, under the name of "le bois blanc." In Germany it is one of the light woods which are extensively employed in the manufacture of children's toys.

It is said that the ancients consecrated this tree to "time," because the leaves are in constant agitation, and, being of a blackish green on one side and white on the other, they were supposed to indicate the alternation of day and night,-

"The poplar, that with silver lines his lenf."

The BIRCH ${ }^{1}$ is a native tree, and even now forms considerable forests in Scotland, yet it never attains any great size. This is one of the most graceful of trees from its slender delicate twigs, and drooping tendency of the branches, especially in some of its varieties. The leaves are small, somewhat triangular in shape, with the lower angles rounded, and the margin irregularly toothed. The chief position which

1 Betula alba. 
the birch occupies in our southern woods is as a coppice-wood, or mixed with firs as a cover for game.

The slender twigs of the birch are used for brooms and another purpose too obvious to juveniles to need

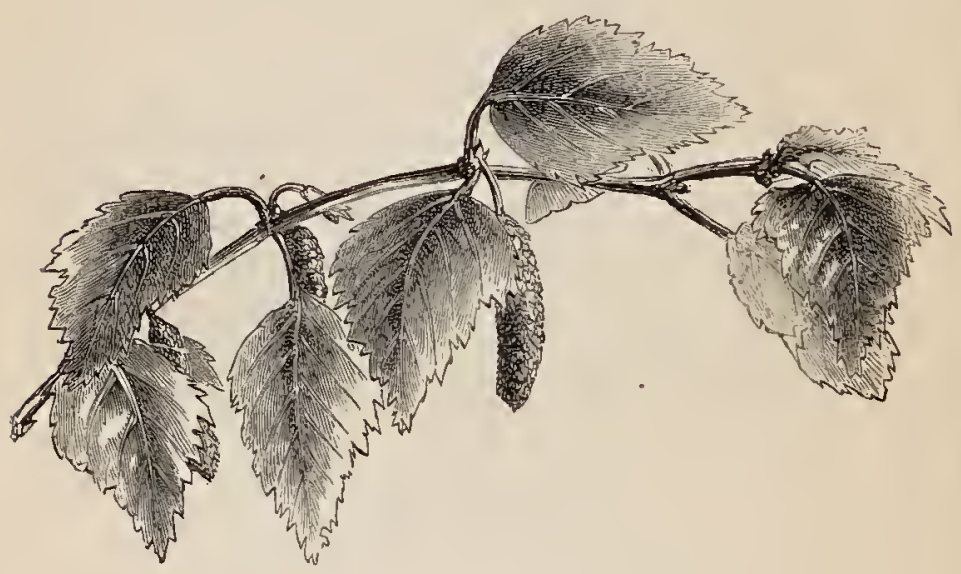

LEAF AND FLOWER OF THE BIRCII.

mention. In early Rome the lictors had their fasces made of the branches of this tree.

The bark of the birch readily separates into thin papery layers, so that in early times it was employed for writing upon. The books which Numa composed (700 B.C.) were written on birch bark.

The sugary sap of the birch as it rises in March is collected in some northern countries of Europe and converted into wine. Loudon states that a birch has been known to yield in the course of one season a quantity of sap equal to its own weight. During 
the siege of Hamburg by the Russians in I8I 4 almost all the birch trees in the neighbourhood were destroyed by the Boshkirs and other barbarian soldiers in the Russian service, by being tapped for their sap.

A considerable list might be compiled of the varied uses of different parts of the tree, which Coleridge calls the "Lady of the Woods"; and many quotations from the modern poets, in its praise and honour, not omitting Shenstone's school children watching a birchen tree,--

"For not a wind might curl the leaves that blew But their limbs shudder'd, and their pulse beat low; And, as they look'd, they found their horror grew And shaped it into rods, and tingled at the view."

The Chestnut ${ }^{1}$ is an Asiatic tree, which has for many centuries been cultivated in Europe. The leaves are lance-shaped, six or eight inches in length and two inches in width, with veins proceeding direct to the margin, and forming a tooth, so that the edges of the leaves are serrated with distant teeth. The fruit seldom attains any degree of perfection in this country, although in some seasons better than others.

In many woods the chestnut is only an under shrub, but in France we have traversed large woods composed entirely of this tree. In parks and open places it attains to a greater size than the oak, and will reach to a considerable age.

The chestnut tree is said to have been brought into

1 Castanca vesca.

D 2 
Europe by the Greeks from Asia Minor, about 504 B.C. Theophrastus says that in his time Mount Olympus was nearly covered with chestnut trees; and Pliny says that the nuts were ground into meal and made into bread by the poor. Etna is celebrated for the great age and colossal dimensions of its chestnut trees. The noted Castagno di Cento Cavalli has a circumference near the root of one hundred and eighty feet, the Castagno di Santa Agata seventy feet, and the Castagno della Nave sixty-four feet. The name of "Cento Cavalli" is said to have its origin in this wise. When Jean of Arragon visited Mount Etna, attended by her nobility, they were caught in a heavy shower; then the queen with a hundred cavaliers took shelter under the branches of this tree, which completely covered them from the rain.

Lovers of roasted chestnuts will remember that Martial says, -

"For chestnuts roasted by a gentle heat, No city can the learned Naples beat;"

and that Milton alludes to the hearth where

"Blackiening chestnuts start and crackle there."

The Horse-Chestnit ${ }^{1}$ is the only conspicuous flowered tree we have. The flowers in the majority of our large trees are small and greenish, so as scarcely to be seen; but in this tree they are pink and white, growing in pyramidal clusters; and when a number of trees are in full bloom, as they are annually in Bushy Park, it is a sight well worth a

1 Assculus hippocastanum. 
journey to see. The leaves are large, with seven lobes cut down to the base, or leaflets spreading like the fingers, at the end of long foot-stalks. This is not a native tree, but is acclimatized and bears the climate well, growing rapidly, and soon attaining a very large size.

The fruits are well known, especially to children, but they are unwholesome and dangerous. In France starch has been manufactured by washing from the rasped horse-chestnuts, which, like all other starch, is quite edible, though of little or no use as an article of diet.

In Lincolnshire is a tree said to be the largest in Britain, with immense branches extending over a space of three hundred and five feet in circumference; the branches are so large as to require props, so that at a little distance it looks like an Indian banyan tree. At Coombe Abbey, in Warwickshire, a tree little more than one hundred years old has a trunk seven feet three inches in diameter.

According to M. Sainte-Hilaire the horse-chestnut was brought from the mountains of Thibet to England in 1550 , and was afterwards taken to Vienna by Clusius, and thence to Paris. The earliest notice of it in England is in Gerard's Herbal, where, in I 579, he speaks of it as a rare foreign tree. From Vienna this tree also found its way into Germany, and was introduced into Baden towards the close of the sixteenth century. It is now generally cultivated in Furope and North America.

The LiME ${ }^{1}$ is a favourite tree for park avenues, and 
is common throughout Europe. It is the inner bark of this tree which is used in Russia for the manufacture of the "bast" matting so commonly used in this country by nurserymen and others. The leaves are heart-shaped, sharp-pointed at the apex, and seated upon a long foot-stalk. The perfume of lime trees about midsummer, when in full bloom, is powerful and agreeable. At that time they are very much frequented by bees. These trees attain to considerable dimensions, and will live and thrive for two hundred years. Eight miles from Worcester there is a wood of about five hundred acres, the undergrowth of which is principally lime. In the same county are trees estimated to be upwards of two hundred years of age. At Ditton Park, in Berkshire, there is a tree known to be upwards of two hundred years old, the trunk of which has a diameter of twenty-two feet ten inches at one foot from the ground. At Moor Park, in Herefordshire, is a lime, the trunk of which measures twenty-three feet three inches, and contains eight hundred and seventy-five feet of timber. In Worcestershire, between Horford and Ombersley, is a tree with a circumference of thirty feet at eight feet from the ground. The celebrated avenue of lime trees in Berlin is now historical.

The wood of the lime has been largely used for carving, many of the fine carvings at Windsor Castle and Chatsworth being of this wood; and it is said that the blocks employed by Holbein for wood engravings were of the same material. Lime-tree honey, which has obtained some repute, is said only to be obtained at a small town in Lithuania, which is 
surrounded by forests of limes, although it is imitated by the Polish Jews.

The HoRnBEAM ${ }^{1}$ is a very common tree in Epping Forest, but in some parts of the country it only appears as a hedge plant. It will attain a height of from sixty to seventy feet under favourable conditions. The leaves are about the size, and have somewhat the form of beech leaves, but are easily distinguished by the deeply serrated edges. The veins of the leaves proceed direct to the margin, with a corresponding depression or furrow on the upper surface, so that they have a plaited appearance. The seeds have a leafy three-lobed wing, and cannot be confounded with the seeds of any other British tree.

At the time when geometrical gardening was in vogue the hornbeam was much employed for fences, labyrinths, arched galleries, \&c. The remains of work of this kind were until lately to be seen near Ghent in a serpentine walk three hundred feet long, covered with hornbeam trained in vaults. At the same place is Pan's Theatre, wholly formed of hornbeam trees and bushes, which the shears have snipped and tortured into the appearance of a stage with side scenes, and of front and side boxes, and parterre or pit. The use of hornbeam as a hedge plant, and for "mazes,"-

"These many windings form a wilderness,

Which hornbeam hedges in trim neatness dress," -

seems to preponderate in all accounts of the trec, to

1 Carpinus betulus. 
the exclusion of all reference to it as a timber tree, which use is amply illustrated in Hainault and Epping Forests.

The $\mathrm{LARCH}^{1}$ is a native of the mountain regions of Germany, but has been introduced into this country for two hundred and fifty years and endures the climate well. It differs in one respect from other trees of the fir tribe in shedding its leaves in the autumn. These are thin, and about an inch in length, collected in bundles or tufts. The trees will attain a height of from eighty to one hundred feet, and produce a very useful timber.

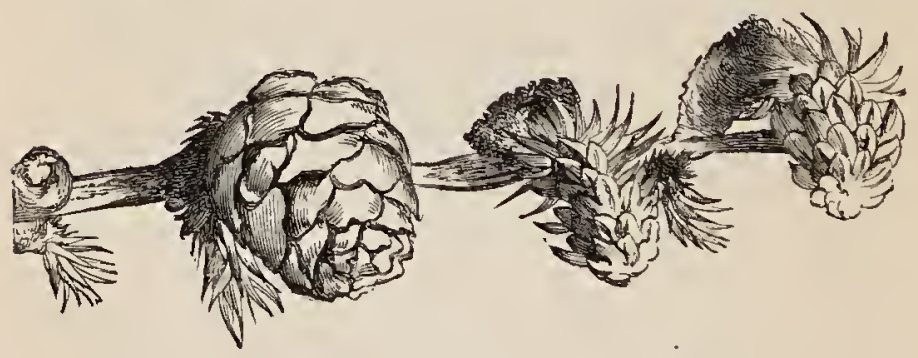

LARCH.

Amongst the timber brought to Rome for the purpose of building the bridge called Naumachiaria (about A.D. 20), was a larch which measured two feet square in thickness throughout from end to end, and was of the length of one hundred and twenty feet, so that the entire tree could not have been less than one hundred and fifty feet. Tiberius Cæsar would not allow it to be used for the erection, but 
commanded it to be placed where all could see it as a curiosity, and it remained for thirty years until Nero employed it in building his vast amphitheatre.

The first allusion to the larch in Britain is by Parkinson, in 1629 , as a rare curiosity; and in 1664 , Evelyn still writes of it as rare; but in 173 , Miller describes it as now pretty common in English gardens. It was about this time that it was first introduced into Scotland, and from that period to the present the Dukes of Athol have become famous for their patronage of the larch. Unfortunately it is subject to a disease, or rot, which baffles all cultivators either to comprehend or to cure.

Many other trees of this order of cone-bearing trees are in cultivation in this country, but chiefly as ornamental trees, such as the spruce, silver fir, cedar of Lebanon, cypress, and others.

The Scotch Pine 2 is common throughout the north of Europe, and the only tree of the tribe which is a genuine native. The leaves are in pairs, and from two to three inches in length. Some of the trees remaining in the old Scotch pine forests are of considerable dimensions. In the Duthal forests some have been measured with a girth of from six to twelve feet at a foot from the ground. In the forests of Abernethy are trees reputed to be from two hundred to two hundred and forty years old; and at Strathspey some which are said to exceed three hundred.

It is this tree which is represented so prominently in the foreground in many of Turner's pictures, and

1 Tliny, lib. xvi. cap. 40.

2 Pinus syluestris. 
the lines of Churchill are as appropriate to it in this situation as in others:-

"That pine of mountain race,

The fir, the Scotch fir, never out of place."

The indigenous pine forests of Scotland have lost their original magnitude and splendour. The sixteen square miles of Rothiemurchus, the wide expanse of Rannoch, are to a large extent dreams of the past, but much of their old glory still attaches to the forests of the Dee, where overhead,-

"At every impulse of the moving breeze,

The fir grove murmurs with a sea-like sound."

In Lapland and Norway it is customary in seasons of scarcity to kiln-dry the inner bark of the Scotch fir and grind it, mixed with oats, into meal. This meal is formed into flat cakes, "covering the bottom of a girdle or frying-pan, and thin as a sheet of paper, being put on the girdle in nearly a fluid state."

The Weymouth pine has been introduced into Britain for a century and a half, and stands the climate of England better than that of Scotland. The leaves ale in clusters of five, by which the tree may be distinguished. 


\section{CHAPTER III}

SMALL TREES, SHRUBS, AND COPPICE.

IN addition to the timber trees which adorn our parks, flourish in the remains of our ancient forests, or are cultivated in woods and plantations, there are numerous smaller trees, which seldom proceed beyond a shrubby undergrowth, but in this capacity often constitute a dense cover. These shrubs vary much in different localities as the soil varies, in some instances being almost composed of a single, or at most of two or three species, and in others consisting of a great variety. Oak, ash, chestnut, and some other large trees are not uncommonly employed as coppice, but beyond these there are a goodly number which seldom or never aspire to the dignity of trees. The character and extent of undergrowth has a considerable influence on the animal life of woodlands. It is useless expecting to find insects in woods which do not furnish the plants on which the larva feed; and birds which build in low shrubs may, in default of finding such shelter, resort to hedges, but are not likely to accept forest trees as a substitute. Herbaceous plants, and even fungi, have great dependence 
upon undergrowth. After a period of some years, when the woodcutter clears away acres of undergrowth, leaving the gaunt and bare trunks of the timber trees standing like spectre sentinels, the whole character of the herbaceous vegetation exhibits a marked change. Plants never seen under the shadow of bushes now appear in profusion, and in the autumn scores of fungi, which before were sought in vain, become plentiful. The following are the principal shrubs usually found as undergrowth :-

The HAZEL ${ }^{2}$ composes almost the entire under-

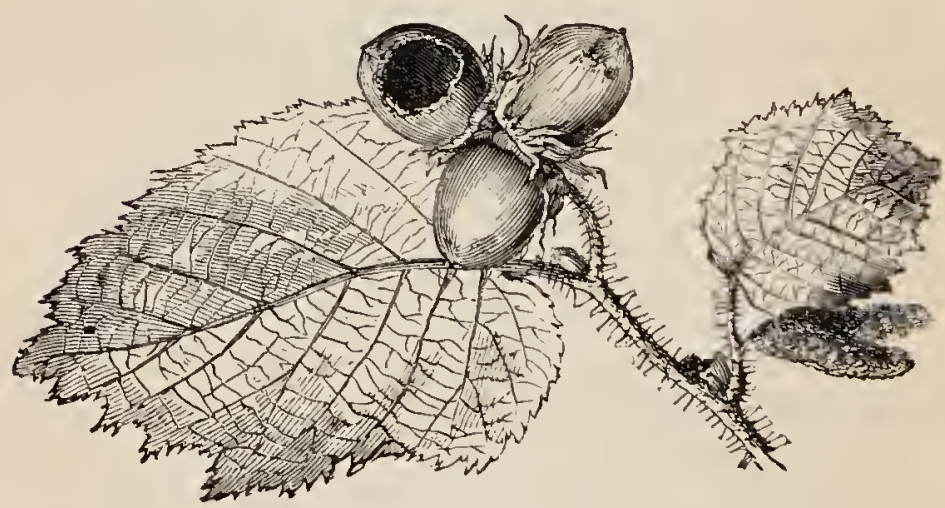

IIAZEL NUTS.

growth in some woodlands, where it is the delight of squirrels, and small boys, in the autumn, when its filberts are ripe. The prevalence of this shrub originated the names of several such places as Hazelbury in Wilts Hazelingfield in Cambridgeshire, and Hazel- 
mere in Surrey. In Kent it abounds in all the native woods.

In the dark ages the hazel was esteemed for its supposed divining powers. More recently magic powers were believed to be possessed by hazel-nuts burnt on All-Hallows eve, as described by Gray:-

"Two hazel nuts I threw into the flame, And to each nut I gave a sweetheart's name. This, with the loudest bounce me sore amazed, That with a flame of brightest colour blazed. As blazed the nut, so may thy passion grow, For 'twas thy nut that did so brightly glow."

The CoRnel or DoGwood ${ }^{1}$ claims a passing notice, although more of a hedge plant than an undergrowth. It is of ancient repute, for

"His cornel spear

Ulysses waved, to rousc the savage war."

This tree, which furnished the ancients with javelins, supplies the moderns with skewers. Parkinson says it was called dogwood because its fruit was not even fit for dogs. The young branches are of a beautiful reddish colour, which become very conspicuous in winter, when all the trees are bare; and in the autumn the leaves of the dogwood assume bright tints, which give a pleasing variety to the usual sombre brown. This shrub is confined chiefly to chalky soils, and is by no means uncommon in the south of England.

1 Cornus sanguina. 
The WrLlows are chiefly found in swampy situations; in marshes, beside rivers, and such places, where a plentiful moisture can be secured. One species, however, is common as an undergrowth in woods, and that is the goat willow or sallow, ${ }^{1}$ with its broad elliptical greyish-green leaves, downy and hoary on the under surface. It is chiefly the catkins of this species which are collected by children on Easter Sunday, and called "palm," a relic of the Catholic ceremony formerly performed in memory of our Saviour's entry into Jerusalem. The early flowering of this willow in spring is considered of importance to bees as furnishing them with food as their winter stores become exhausted. This is also the principal willow which propagates itself by seeds, the others, for the greater part, being propagated by cuttings The willows of Babylon were probably the "weeping willow." 2

The HoLly ${ }^{3}$ is a great favourite, with its spiny, glossy, evergreen leaves and red berries; and in most woods a few bushes will be found scattered amongst the undergrowth. This tree was formerly called Hulver in some parts of England, and is still known by it in Norfolk. It had the name of Holme in the southern counties, and gave its name to many places where it grew in plenty, as Holmwood, near Dorking; and Evelyn says that the vale near his house in Surrey was Holmesdale. The name of holly is an undoubted corruption of holy. Dr. Turner, one of

1 Salix capraa.

3 Ilex aquifolium.

${ }^{2}$ Salix Babylonica. 
our earliest writers on plants, calls it the "Holy tree." In Germany, Denmark, and Sweden it is "Christdorn," or a modified form of that name, evidently indicating its religious associations. Phillips says, "The great feast of Saturn (in ancient Britain) was held in December; and as the oaks of this country were then without leaves, the priests obliged the people to bring in boughs and sprigs of evergreens; and Christians, on the twenty-fifth of the same month, did the like; from whence originated the present custom of placing holly and other evergreens in our churches and houses, to show the feast of

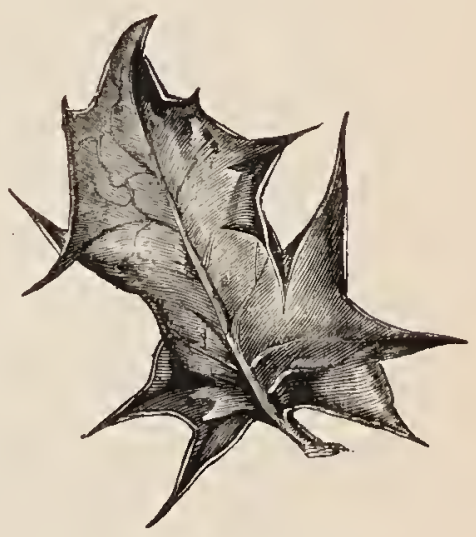

IHOLI.Y LEAF.

Christmas is arrived." No evergreen is so much esteemed for Christmas decoration as the holly, and the berries are in some places known as Christmas berries.

Pliny says that Tiburtus built the city of Tibur near three holly trees, and that these trees were standing in his own time, and must therefore have been one thousand two hundred years old. He also says that there was a holly tree then growing near the Vatican in Rome, on which was fixed a plate of brass with an inscription in Tuscan, and that this tree was older than Rome itself, which must have been more than eight hundred 
years. Undoubtedly the holly will obtain a great age and a considerable size. Withering mentions large holly trees growing on the north of the Wrekin, in Shropshire; and trees sixty feet in height are said to have grown near Frensham in Surrey. In the old forests, as at Needwood, and the New Forest, as well as in forests on the Dee and the Findhorn, in Scotland, holly abounds: in many instances the trees are of considerable size. It is narrated in an old book entitled "Paradise of Plants," that its author knew a holly tree which grew in an orchard, and the owner cut it down, caused it to be sawn into boards, and made himself thereof a coffin, and, if I mistake not, left enough to make his wife one also. Both the parties were very corpulent, and therefore we may imagine that the tree could not be small.

The belief that the leaves of the holly are always spiny below, and without spines on the upper branches, is more poetical than true.

The Mountain Ash, l sometimes called the "rowan," is a well-known, but small tree or shrub, which is conspicuous by its bunches of bright red berries in the autumn. The compound leaves are not unlike those of the ash, but it is more nearly related to the pear and apple-tree, although this would hardly be suspected by any except the botanist. Ancient poets state that the Amazons formed their spears of this wood, by which they boldly defended themselves against mortals. In Wales, Evelyn observes that in his time it was reputed so sacred

1 Pyrus iancuparia. 
that there was not a churchyard without one of them planted in it. It was one of the Druidical trees, and Lightfoot says that it has been observed to grow

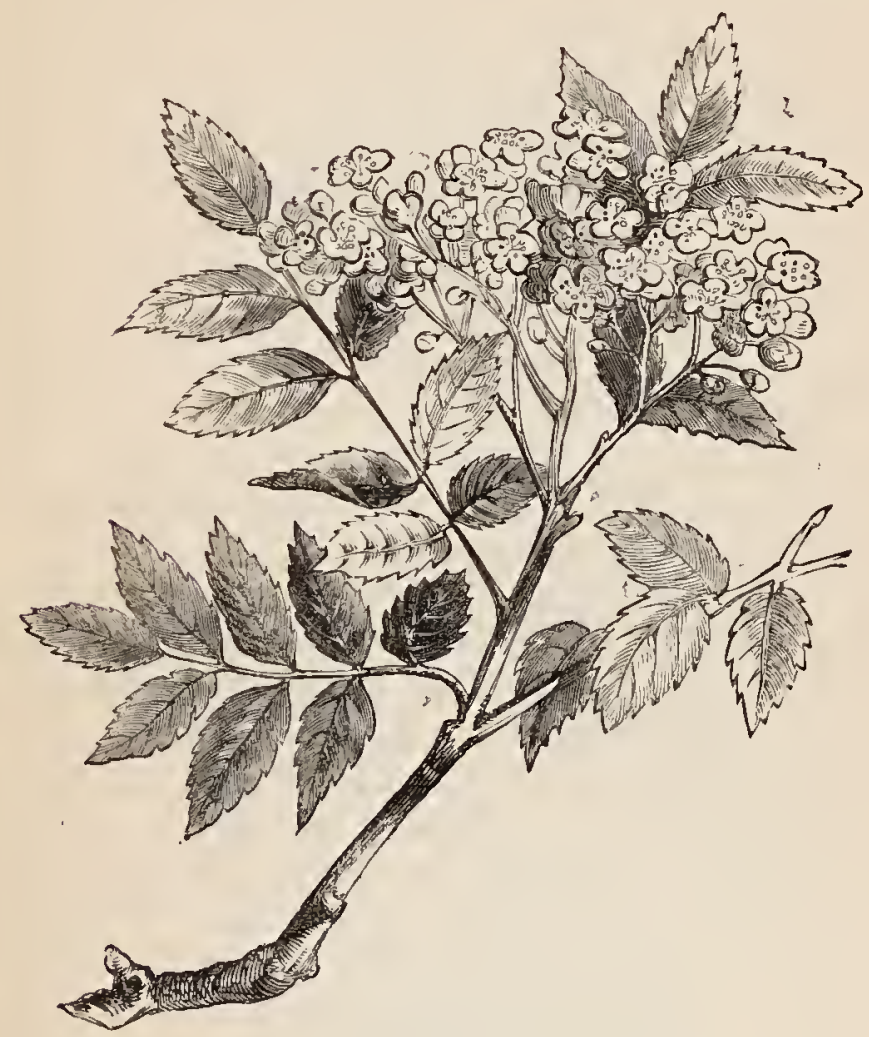

MOUNTAIN ASH.

more frequently than any in the neighbourhood of the ancient circles of stones so often seen in North Britain.

Tha BERBERRY is rather a hedge plant than a

'Berberis valgaris.

$\mathrm{E}$ 
woodland shrub, but sometimes it will be found as an undergrowth. The branches are armed with long straight sharp spines; and its drooping bunches of bright yellow flowers are succeeded by clusters of shining bright red fruit. There is in many localities a very strong prejudice against the berberry as a hedge plant, on account of the current opinion that it is in some way the cause of mildew in wheat.

Loudon says that this tree will live for two or three centuries without increasing much in size. It is found on Mount Etna, Mount Lebanon, and on the slopes of the Himalayas, so that it has a wide range. A medicinal extract is still made in India from the wood and root, apparently identical with that known to the ancients, derived from the same source, two thousand years ago.

The ELDER ${ }^{1}$ is much used in some places for hedges on account of its rapid growth, but beyond this it is thoroughly useless, if we except its juicy berries, which in many country localities still serve to produce a domestic wine, - an old-fashioned Christmas favourite. In woodlands this shrub, with its malodorous flowers, still lingers amongst the undergrowth. It is an antique belief that the strongsmelling flowers of the elder are injurious to health. Evelyn mentions a story of a certain house in Spain being seated amongst elder trees, which diseased and killed almost all the inhabitants, but when the trees were dug up, it became a wholesome place. The elder was considered by the ancients to be emblematical of 
death and sorrow, probably because it was said to produce a narcotic stupor in those who slept beneath

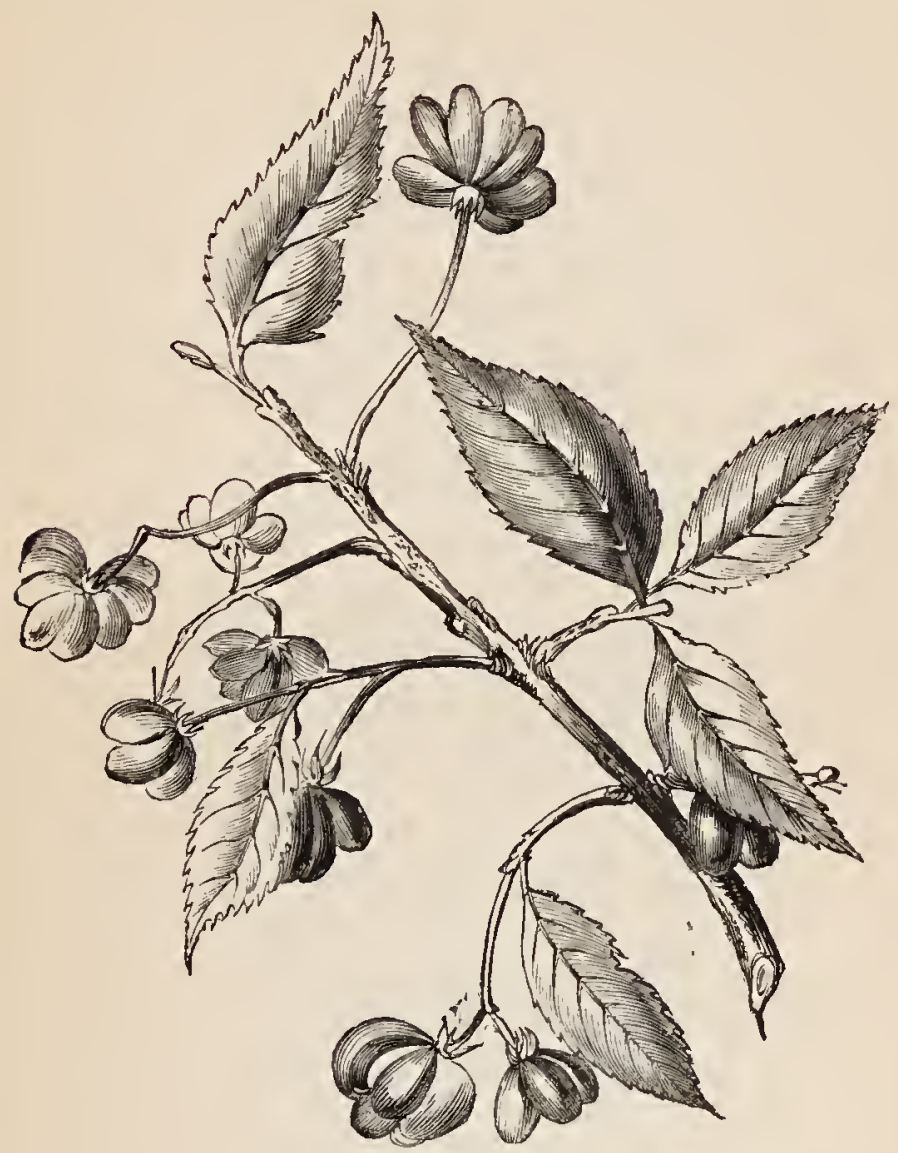

SPINDLE TREE.

its shade, and sometimes to occasion death. Hence all poetical allusions are of a mournful character.

The SPINDLE-TREE ${ }^{l}$ flourishes in woods upon a.

1 Enonymus Europaus. 
chalky soil, and is common in Kentish woods, although as a small straggling bush. The curious quadrangular fruits are rose-coloured or whitish, splitting at the top in a cruciate manner, and exhibiting the orange-coated seeds. The English name of Prick-wood alludes to the employment of the wood for toothpicks and skewers, which were formerly called "pricks." In some of the Scottish woods the trees abound, and are of a larger size than in England. In Forfarshire they may be seen from twenty-five to thirty-five feet in height, with trunks a foot and upwards in diameter. In Germany the wood is still said to be used for making spindles, whence originated the name of "spindelbaum," or spindle-tree; but, besides this, the sticks are bored, and used as shanks for the earthenware tobaccopipes so universally in use amongst the Germans.

The Guelder Rose, ${ }^{1}$ and its companion the Mealy Guelder Rose, ${ }^{2}$ mingle in the undergrowth of woods on the south side of London, apparently preferring a chalky soil. In its wild condition the former does not produce the round white clusters of abortive flowers, resembling a snowball, which are the ornament of the cultivated variety, but the smaller and irregular tufts really produced are fertile towards the centre. The mealy Guelder Rose is very conspicuous in the autumn and winter, when the large flat clusters of bright red berries are nodding and bending beneath their own weight. The young twigs and large elliptical leaves on the underside are

1 Viburnum Opulus.

2 Timumum Lantana. 
covered with a dense coating of stellate hairs, which give the shrub a hoary or mealy appearance. The Dutch are said to have named this the Geldersche Roose, because they had it from Guelderland.

The BucKTHORN ${ }^{1}$ is almost exclusively a hedge plant, but the Alder Buckthorn ${ }^{2}$ is not uncommon in some woods, although totally absent from others. It is certainly local in its distribution. There are several species of Rhamnus, or buckthorn, more or less cultivated, but the above are the only kinds we have seen in woods. All of these contain a large amount of colouring matter, both in the bark and the berries, so that both are employed in dyeing. The yellow berries, or Turkey berries, imported into this country from the Levant, as a dye, are produced by two kinds of Rhammus, which do not fruit here. The small, greenish-white flowers of this shrub are said to be particularly grateful to bees; the name of frangula is said to be applied to it because of the brittleness of its branches, but why it should be called the alder buckthorn is not so clear, as it does not resemble the alder in any feature.

The BOX-TREE ${ }^{3}$ was formerly much more common with us than now. In the time of Gerarde it was said to grow upon sundry waste and barren hills in England. And Parkinson states that in the time of Charles I. it was found with us in many woods. Boxwell, in Gloucestershire, was so named from the box; and Box-hill had its origin from the same plant.

\footnotetext{
1 Rhammus catharticus.

3 Buxus sempervirens.

2 Rhammus frangila.
} 
The neighbourhood of Dorking is still beautified by extensive shrubberies of box. In many parts of Asia the box, which is a slow-growing tree, attains a considerable size, and, as yet, its wood has been unequalled for wood-engraving, for which purpose it is very extensively employed. Virgil says,-

"Nor box, nor limes, without their use are made, Smooth-grain'd and proper for the turner's trade,

Which curious hands may carve, and steel with ease invade."

The BIRD-CHERrYl is not uncommon in the Scottish woods, although by no means common in England. Gerarde says that in 1596 it grew wild in the woods of Kent, where it was used as a stock to graft cherries on. It is still to be met with scattered over the Kentish woods. This is a native of most parts of Europe, and is plentiful in Northern Russia. Birds are very fond of its berries, hence its name of Bird-cherry, and its Latin name of padus was probably applied by the Romans after the river Padus, the ancient name of the Po.

The Service ${ }^{2}$ is sometimes found in woods; but this is not the true service-tree, which is very rare in Britain. The wild service is still to be seen in the woods on the north side of London, where it was noted as growing more than a century ago.

The WhITE BEAN-TREE ${ }^{3}$ is more common than the wild service, with its large ovate, doubly-toothed leaves, white and woolly on the under surface. It seems to prefer a chalky or limestone soil, but is

- Pyrus ariz.

3 Pyrus torminatis.

2 Promus padus. 
found scattered over a great portion of the country. This tree appears to have been known to the country people all over Europe, for in every nation it has its

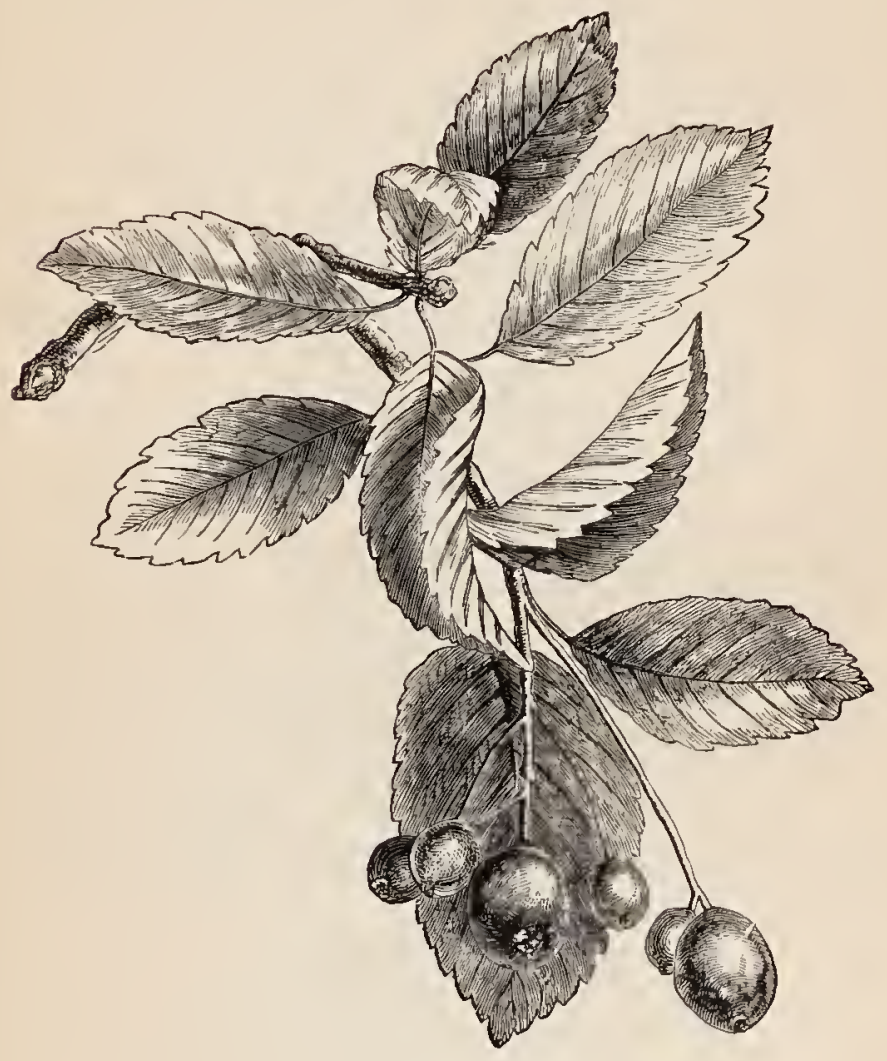

THE WHITE BEAN.

own popular name. The white beam is simply the "white tree," beam being the Saxon, as baum is now the German word for "tree." In Germany this is 
called the mealy tree (Mehlbaum), from the mealy appearance of the under-side of the leaves. The fruit is small, and rather acid, but not disagreeable when bletted, or in a state of incipient decay, as medlars are eaten. It is not usually eaten by man, but is much relished by birds, squirrels, \&c. The beer formerly made from it by fermentation, or the distilled spirit, does not seem to be now known.

The AsPeN ${ }^{1}$ is as often found in hedgerows as in woods, but chiefly in damp situations. The leaves are suspended on long flattened stalks, so that-

"When zephyrs wake

The aspen's trembling leaves must shake."

One of the most curious superstitions respecting this tree is that referred by Loudon to the Highlanders, who believe that the cross of Christ was made of it, and that, consequently, it can never rest. Old Gerarde in his quaint manner compares the leaves to women's tongues, for they "seldom cease wagging." Of course women have their revenge, and do not consider Gerarde's book as worthy to be read. Even Sir Walter Scott sinned in the same direction when he wrote-

'Oh, woman! in our hour's of ease

Uncertain, coy, and hard to please,

And variable as the shade

By the light quivering aspen made."

The ALDER ${ }^{2}$ is found in low swampy woods all over Europe. In such situations it sometimes becomes

1 Populus tremula.

2 Alnus slutivosa. 
a considerable tree, but in dry places and on mountain slopes it is but a dwarf shrub. Virgil says that the first boats were built of its wood; and Pliny calls the wood "eternal" for water-pipes and piles for buildings. Evelyn states that the bridge of the

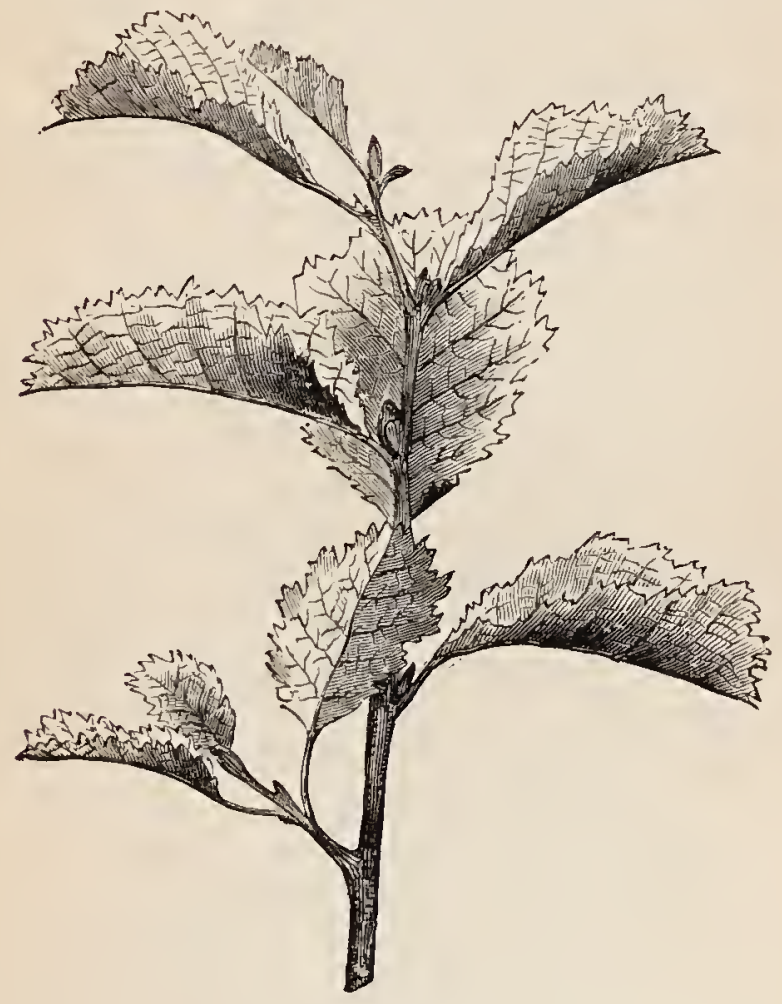

THE ALDER.

Rialto, in Venice, is built on piles of alder wood; and Vitruvius, that the city of Ravenna was erected on alder piles. The Dorset woodmen have a similar 
faith in its indestructibility for rafters, as expressed in their adage,-

\section{"Thatch me well, and keep me dry, Heart of oak I will defy."}

One of the reasons which have been alleged to account for the absence of large alder-trees is, that the wood is required for so many of the small uses of man, as oak is of the large ones, that they are not allowed to stand long enough to become large trees. It is, nevertheless, certain that the wood is a very useful one for many purposes. There is a little beetle which is very destructive to the wood, and for this reason the "sabots" made of it in France are smoked so as to preserve them. Sir Thomas Lander suggests, that if the logs be immersed in a large hole, dug in a peat-moss, impregnating the water of the hole with a quantity of lime, and left there for a few months, they will be safe from attack. Probably one of the chief uses for alder is the manufacture of charcoal for gunpowder manufactories, it being held in great esteem for that purpose, This use is in harmony with the poet's description-

"The rigid alder its stiff image throws

Gloomy and sad, as though it scorned to please :

Emblem of woe, too great to be expressed,

Which broods in silence, and corrodes the breast."

The Butcher's BROonl ${ }^{1}$ is a most insignificant little evergreen, often not half a yard in height, and seldom exceeding three feet, and yet it is to be found scattered through woods in different parts of the 
country, where it is known also as the knee-holly, or knee-hulver. The Greeks called it by a name which corresponds to "prickly myrtle," for it was known to Greeks and Romans. What are called its leaves are not in reality leaves, though assuming the form and size of myrtle leaves, except in being thicker, and terminating in a sharp prickle. The little, inconspicuous flowers grow from the sides of these leaves, and there the bright red berry is finally perfected. The plant was called butcher's-broom (so it is said) because of the custom of binding it into besoms for sweeping butchers' blocks, and defending their meat from flies.

We might allude also to the Privet and Broom, the Hawthorn, Sloe, and Hedge Maple, but these are more especially plants of the hedgerows. We might write of the beauties peculiar to spring which the delicate green hues of the fresh-opened leaves of the undergrowth impart to the woodlands; of the mellow tints of autumn with its purple and gold; and then conclude, as Longfellow has done-

"O what a glory doth this world put on For him who, with a fervent heart, goes forth Under the bright and glorious sky, and looks On duties well performed and days well spent. For him the wind, ay, and the yellow leaves Shall have a voice, and give him eloquent teachings. He sliall so hear the solemn hymn, that Death Has lifted up for all, that he shall go To his long resting-place without a tear." 
CHAPTER IV.

FLOWERS AND GRASSES.

As different plants blossom at different periods of the year, no one can expect to find all woodland flowers at the same time; but in order to become acquainted with them must make separate excursions during spring and summer. Similarly the odours which perfume a wood will vary, as one flower with strong odour will reign supreme over all the rest. When the little woodruff expands its little insignificant white blossoms, the wood will have that peculiar scent which resembles new-mown hay. Others not equally pleasant will predominate at times. Whether in flower or fruit there will ever be sufficient material at hand for study, if the inclinations tend in that direction.

One of the earliest of flowers is-

"The coy anemone, that ne'er uncloses

Her leaves until they're blown on by the wind."

The wind flower, or wood anemone, as it is called, is a very delicate little harbinger of spring. The true leaves do not make their appearance until after the flowering is past. The three leaf-like bodies 
which stand together, half way up the stalk, supporting the flower, are not the true leaves, which latter proceed direct from the root, but bracts, or false leaves. The curious little black root-stocks lie dormant in the ground during the winter, but begin to sprout as soon as the snow has passed away.

The Crowfoot is another early flower, or, as it is more commonly called, "Buttercup." There are several species, but all of them are only known to the majority of people as buttercups. Yet the true buttercup of the woods is a different plant from those of pastures or roadsides. There is another name. that of Goldilocks, which is sometimes applied to the wood buttercup. ${ }^{1}$ The yellow flowers of all the species are very similar in form, though differing in size, and hence the whole plant must be studied in order to distinguish one species from another. It is worthy of note that although other kinds of buttercup, if the leaves are tasted, will be found acrid and biting to the tongue, those of the wood crowfoot are mild.

All the violets more or less flourish in the reputation of the sweet-scented violet. It might be propounded that the scentless violets have assumed the form and colour of the scented species as a protection; or that the odorous violet has been evolved from the inodorous by natural selection, for some inscrutable purpose. Conjectures of this kind are by no means rare, and equally probable. All poets in all ages have sung in praise of this "lowly flower,"

1 Kanunculus auricomus. 
and miraculous virtues have been assigned to it which it never deserved. Homer wrote of-

"Meadows of softest verdure purpled o'er With viclets; it was a scene to fill

A god from heaven with wonder and delight."

In the autumn seed-vessels are often observed on plants of the sweet violet, when no flowers had been previously seen. These result from inconspicuous flowers, consisting of the essential parts, but deficient in the floral leaves, which are produced as a second crop. Cottagers will sometimes allude to this mysterious circumstance of seeds being produced without flowers, as they believe, which adds to the reverence with which they cherish the plant.

The only wild representative of the "Pink" of gardens, which is found in woodlands, is the Red Campion, ${ }^{1}$ although there are two or three stitchworts, which belong to the same order, common in such localities. Some of the plants of this family are very subject to the attacks of parasitic fungi. In some the centre of the flower, which is occupied by the stamens, is black with the soot-like powder of one of these parasites. In other cases the parasites are found on the leaves, those of the little three-veined chickweed being seldom exempt. The seeds of the red campion afford pretty objects for the microscope. They are somewhat kidney-shaped, and rough on the surface. A similar character prevails throughout the family. The petals in the chickweeds are notched at the apex, but it will be observed in the Wood 
Chickweed ${ }^{I}$ that this notch is so deep that the flowers seem to consist of twice as many petals as they really possess. Country children call the flowers of the stitchwort "Ladies' Thimbles." How these little white flowers come to be associated with thimbles and stitches those learned in folk-lore alone can tell.

Saint John's Wort indicates the dedication of a piant bearing that name to St. John. The true St. John's Wort ${ }^{2}$ is not a woodland species, but the Tutsan $^{3}$ is not uncornmon in the Kentish woods. The flowers are of a golden yellow in all the species, with a large number of radiating stamens in the centre. In the days of witchcraft the St. John's wort was a plant of importance, for it was considered a sovereign remedy for all diseases resulting from magical influences. That it had also other virtues is intimated in the lines-

"Thou silver glow-worm, oh lend me thy light, I must gather the mystic St. John's wort to-night ;

The wonderful herb whose leaf will decide If the coming year shall see me a bride."

In Lower Saxony there is a superstition that if the plant be gathered by maidens on Midsummer night and hung up in their bedchambers, its fresh or withered appearance in the morning will betoken whether they are to become brides during the ensuing year.

The Cranesbills (Geranium) are sometimes to be found in woods, but chiefly on hedgebanks and in

1 Stellaria nemonum.

3 Hypericum androsamam.

2 Hypericum perforatum. 
waste places. The name is derived from the long beak in the centre of the fruits.

The Wood Sorrel ${ }^{1}$ is a delicate little plant with three-lobed leaves, resembling those of the white clover. The flowers are pinkish-white, on slender peduncles, often concealed amongst the leaves, and are called in Wales "fairy-bells." It has been contended that this is the true "shamrock," whilst others

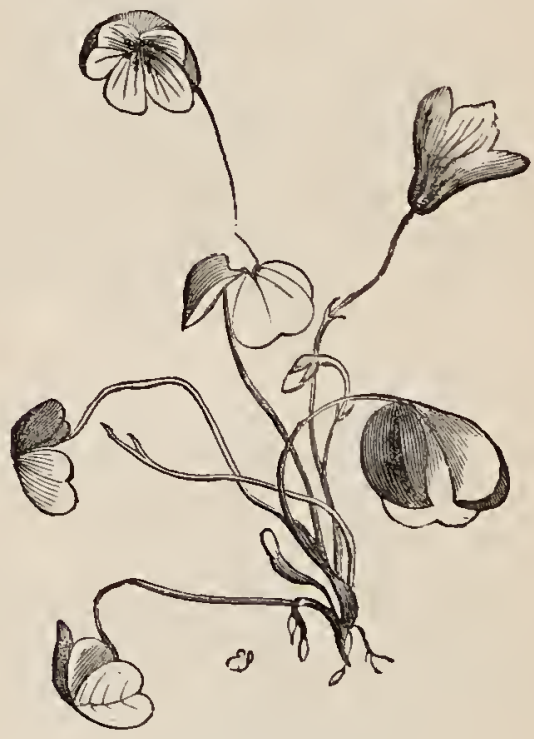

WOOD SDRREL.

hold that magical plant to be the white clover. The evidence is greatly in favour of the wood sorrel, whilst the Irish practice is in favour of clover. The ancient Druids held the wood sorrel in veneration,

1 Oxalis acctosclla. 
and the old monkish herbalists called it "Hallelujah." The taste of the leaves of this plant is a pleasant acid, and they have been eaten in Ireland from time immemorial as a spring salad. It is a plant very sensitive to the changes of the atmosphere, not only closing its flowers and folding its leaves at sunset, but also as the result of rude handling or blows.

Of the large number of plants belonging to the pea-flower family only a few are sylvan in their habits. Of these may be mentioned the Bush Vetch ${ }^{1}$ and the Wood Vetch, 2 the latter being the most rare of the two-
"And where profuse the wood vetch clings
Round ash and elm in verdant rings,
Its pale and azure pencilled flower
Should canopy Titania's bower."

The pretty little Grass-leaved Vetch, ${ }^{3}$ with its solitary crimson flowers, is one of the stray gems of southern woods. Before flowering the plants cannot be distinguished from the grass amongst which they grow, and it is only by the bright flowers that they are discovered; hence the plant is considered rare. The tuberous-rooted Bitter Vetch ${ }^{4}$ is the only other plant of the family which need be named of the whole number of nearly eighty that are British.

The little Barren Strawberry, ${ }^{5}$ so common on the ground in woods, is with difficulty distinguished by the uninitiated from the Wild Strawberry. ${ }^{6}$ So

1 Vicia sepium.

2 Vicia sylvatica.

3 Lathyrus nissolia.
4 Orobus tuberosus, L.

- Potentilla fragariastrum.

6 Fragaria v'essa. 
plentiful is the wild strawberry in the woods and forests around the city of Vienna, that during the season the fruit may be seen exposed for sale in the markets, and at all the fruit shops in profusion. The little wood strawberry is undoubtedly the parent of many of the varieties in cultivation. The Vienna wild strawberry is probably the "Hautbois," which is the

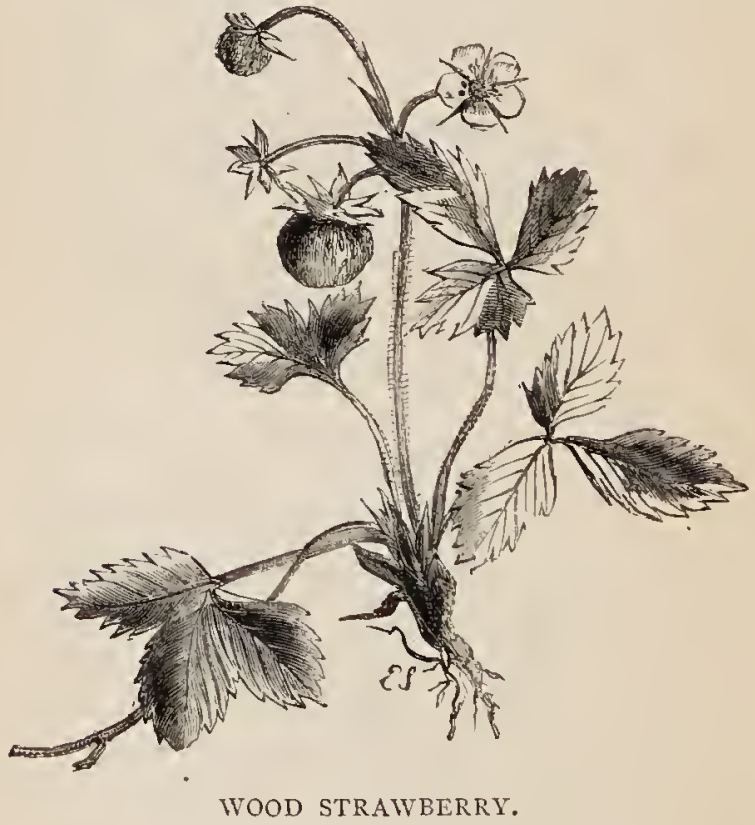

parent of another group of cultivated varieties. As to the origin of the name of "strawberry" no feasible explanation has yet been offered, though several have been attempted.

The wild raspberry, as found in woods, differs less from the commoner kinds of cultivated raspberry 
than do the strawberries. The fruit has the same flavour, although smaller, and the habit and foliage of the plants is almost the same. The raspberry plant is a "bramble" as well as the blackberry, but, of course, a different species. Indeed, some botanists recognize so many different species of bramble that it is extremely difficult to distinguish one from another, but of the difference between the raspberry and the blackberry there is no room for doubt. Out of the forty supposed species of bramble it would be fruitless to attempt to distinguish those commonly found in woods. Some of them have more pleasant fruits than others, and some are more thorny than others, but to us they must all remain as brambles, and nothing more.

The wild roses are almost as prolific in species as the brambles, and almost as difficult for the nonscientific to distinguish from each other, except, perhaps, in a few strongly-marked instances. There is, for instance, the sweet-briar, which is not a woodland species. Then there is the common dog-rose, many forms of which are found in thickets; but for more than twenty kinds of dog-rose, some say species, we shall simply refer our readers to some botanical manual in which they are fully described, declaring simply our own faith in the "dog-rose," and leaving the discovery of minor distinctions to those who have the taste and leisure to pursue the investigation.

According to old legends, the rose was created without thorns, which grew on the plant in consequence of the wickedness of man. Poetry and romance, in the East and the West, are rich in 
imagery, redolent with the odour of the rose. The red and white roses occupy a place in English history not soon to be forgotten.

Attention should be directed to a large family of plants, some of them very useful, in which the small flowers are usually produced at the apex of short pedicels which radiate from a common centre, and form a broad flat expanse of flowers, on the same level, as in the cultivated carrot and parsnip. of this family some are found in woods, and amongst them the Wood Sanicle, ${ }^{1}$ in former times so highly esteemed for its medicinal virtues that it was said "he who keeps sanicle has no business with a doctor." It has been supposed that this plant, being dedicated to Saint Nicholas, its present name is a corruption of Saint Nickel, as "sanicle."

The Pig-nut, or Ground-nut, of schoolboys, is the round tuberous root of a plant of this family, ${ }^{2}$ not at all uncommon in open places in woods, as well as churchyards, and other open places. These roots are about the size of a filbert, sweet and pleasant, much relished by pigs, and they easily find them out by their scent, and root them up.

The wild Angelica ${ }^{3}$ has much of the odour of the garden angelica, and some of its qualities. The tall hollow stems of this and the common Cow-parsnip ${ }^{4}$ are prominent objects in woods; especially in autumn and winter, when dead, withered, and dry, they stand, four or five feet in height, as monuments of their

1 Sanicula Europara.

3 Angelica syluestris.

2 Bunium flexuosum.

4 Heracleam spondylium. 
summer glory. The stems of a third species, in the hemlock, are common in the same localities.

The little Woodruff, with its whorls of bright green leaves and small white flowers, is a general favourite, on account of its hay-like odour, which increases with the drying of the plant, and is retained for years.

The wild Teazel ${ }^{l}$ is common enough in the Kentish woods, and was formerly in repute for the maggots in its head, which, being suspended from the neck of a person afflicted with ague, were said to work a marvellous cure. Gerarde confesses that, having "a grievous ague, and of long continuance, notwithstanding physicke charms, these worms hanged about my neck, spiders put into a walnut-shell, and divers such foolish stories, that I was constrained to take by fantasticke people's procurement ; notwithstanding, I say, my helpe came from God himself, for these medicines and all other such things did me no good at all."

Persons deficient in botanical knowledge, and not in the habit of close observation, consider the flowering heads of composite plants, such as the daisy and dandelion, as simple flowers, whereas, if they would sit down and pull one of these flowering heads in pieces, they would find a vast number of flowers, each more or less complete in itself, compactly seated upon a cushion-like expansion of the top of the stem, and thus constituting a dense head of miniature flowers. Usually those of the margin have one of the petals elongated, whilst those of the centre, or

1 Dipsacus sylvestri. 
disc, have the petals equal. A little study of these flowers by those unacquainted with their structure will amply repay the trouble.

Some of the plants which possess a structure of this kind are habitually found in woods. The

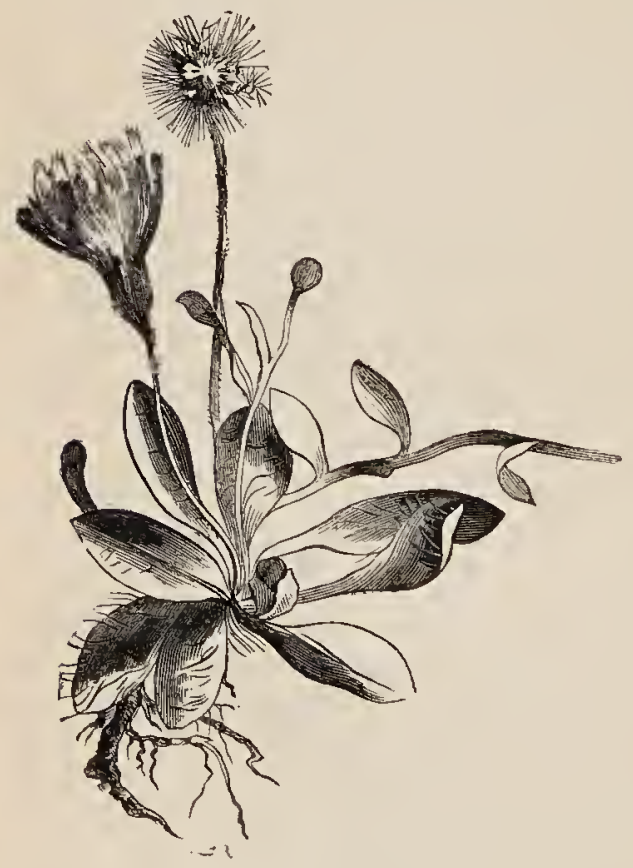

HAWIIWEED. purple-headed Saw - wort, 1 something like a small "knapweed ;" the tall erect "Goldenrod," 2 at one time called "woundwort" and enjoying a good repute as a vulnerary, for which a high price was paid as a foreign herb, until it was found growing wild near London, when Gerarde says it was neglected; some hawkweeds, ${ }^{3}$ more easily to be named than described, usually yellow; and perhaps a "groundsel" or two, with here and there a "sowthistle." 4 To the ordinary observer these are very
1 Siratizla.
2 Solidaso.
3 Hieracium.
${ }^{4}$ Sonchus. 
uninviting flowers, and even children seldom care to add them to their nosegays; but to the lovers of nature's marvels they will furnish much material for study and reflection.

When the flowers have faded and the seeds are ripened, these plants still furnish material for observation. Each seed, or fruit, is terminated at the apex with slender filaments supported on a long. pedicel; sometimes these are interlaced in an expanded disc, so that the appearance is not unlike a miniature parasol. These winged fruits are borne upon the wind to a very great distance; and the evident use of such appendages is to aid in the dispersion of the seeds. Let the dandelion, or any species of "ragwort," or thistle, be observed when the heads are ripe, and this mode of dispersion will at once be manifested. Perhaps one of the most perfect of "parachutes," in our common composite plants, will be found on the "goatsbeard," which springs up freely on railway banks. The manner in which the seeds of plants aid in their own dispersion by the means of wings, hooks, spines, \&c., or by some special contrivance of the capsule, is deserving of observation.

"Blue-bells" is a name often inaccurately given to the wild hyacinth, but the true "blue-bells" are undoubtedly species of Campanula. The erect large bell-flower, not uncommon in woods in the south of England, is sometimes called Canterbury-bells, ${ }^{1}$ from its supposed resemblance to the bells carried by the 
Canterbury pilgrims. The leaves are not unlike those of the nettle, excepting the stinging hairs. In

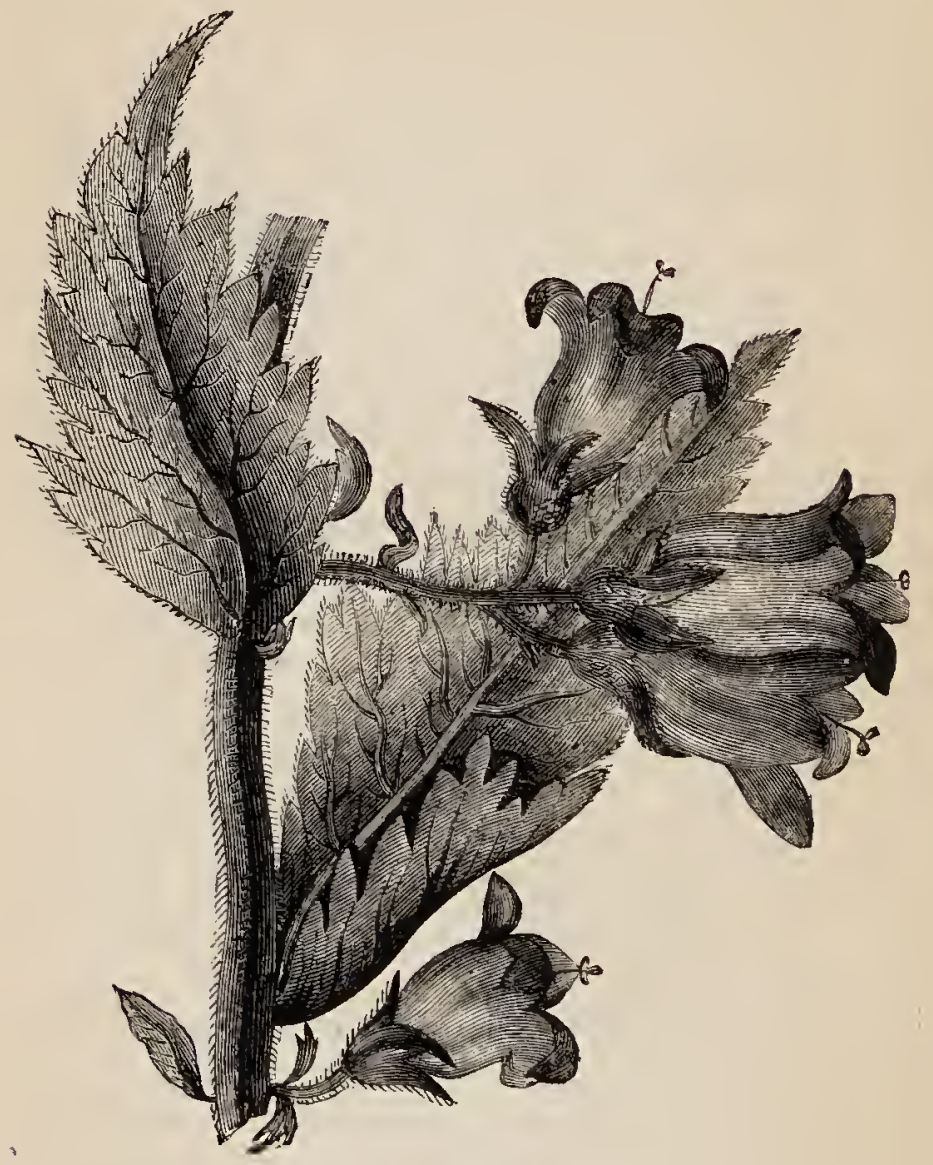

NETTLE-LEAVED BELL-FLOWER.

Scotland this plant is replaced by another species which is very rare in the south. The pretty little hare-bell, known to every village child, and often 
called "witches' thimbles," is a plant of heaths and open places, -

"The hare-bell that, for her stainless azure blue,

Claims to be worn of none but those who are true."

Heathy woods in the north are often sprinkled with patches of the spreading, tough, wiry stems and evergreen leaves of the red Whortleberry. ${ }^{1}$ The little pendant flowers, of a pale pink colour, grow in small clusters, and are succeeded by a shining succulent black berry, which may be made into tarts, and are said to be sometimes sold as cranberries. The bright green leaves of this plant somewhat resemble those of the box, and the flowers are not unlike those of some kinds of "heath." Another species is much more common in similar situations in the south. This is the Bilberry, ${ }^{2}$ often seen in large patches covering the ground in woods, as in the neighbourhood of Shere in Surrey, and other places. The flowers resemble those of the whortleberry, but grow singly, and the leaves are deciduous. The berries also are edible. These two are, properly speaking, miniature shrubs.

One of the most conspicuous plants in the Kentish woods, and not uncommon throughout the country, is the Foxglove, ${ }^{3}$ well known in gardens. The tall spikes of thimble-shaped purple flowers make it an imposing object wherever it

"Rears its pyramid of bells

Gloriously freckled, purple and white."

1 Vaccinium vitis $I$ doca.

3 Digitalis purpuraa.

2 Vuccinium myrtillus. 
Whether the name of "foxglove" is a corruption of folk's-glove, in allusion to the "little folks" or fairies, or whether it had any other origin, it would scarce be profitable to inquire. In Wales it is still believed that fairies lurk in the pendant bells of this flower. More prosaic persons hold with Wordsworth, that

"The foxglove now in crimson tresses rich

Depends, whose freckled bells to insect tribes

Afford a canopy of velvet bliss."

The "insect tribes" are the only "little folks" which inhabit the foxglove bells in modern times.

The Speedwells are sometimes erroneously called forget-me-not, but that name belongs to quite a different plant. Although we have several species of speedwell, they are not common in woods. The kinds most usually met with in such localities are the common Speedwell ${ }^{1}$ and the Germander Speedwell; ${ }^{2}$

"Flower whose hedge-side gaze is like an infant's,"

indicates that it is as common on hedge-banks. The closing of the flowers at night is alluded to by the Ettrick Shepherd in the lines-

"When the blewart bears a pearl, And the daisy turns a pea ;

When the bonnie lenken gowan Has fauldit up her e'e."

The Cow-wheat ${ }^{3}$ is one of those plants which annoy plant-collectors by its persistent habit of turning black in drying. Why it came to be called "Cow-wheat"

1 Veronica officinalis.

3 Melampyrum pratense.

2 Veronica chanedrys. 
has never been very satisfactorily explained. It is said that there was an old notion that the seeds falling to the ground were transformed into wheat, but this would only in part account for the name. It is a poor straggling plant, with little to recommend it to notice, except its being very common in every wood.

Two curious parasitical plants are now and then to be met with in woods. Neither of them has true leaves, but the stem is clothed with scales. One called "Bird's - nest," 1 at the roots of beeches and firs; the other "Toothwort," growing on the roots of hazel, oak, ash, elm, and other trees. These are such singular-looking plants, from their livid, pallid hue, absence of leaves, and coarse habit,

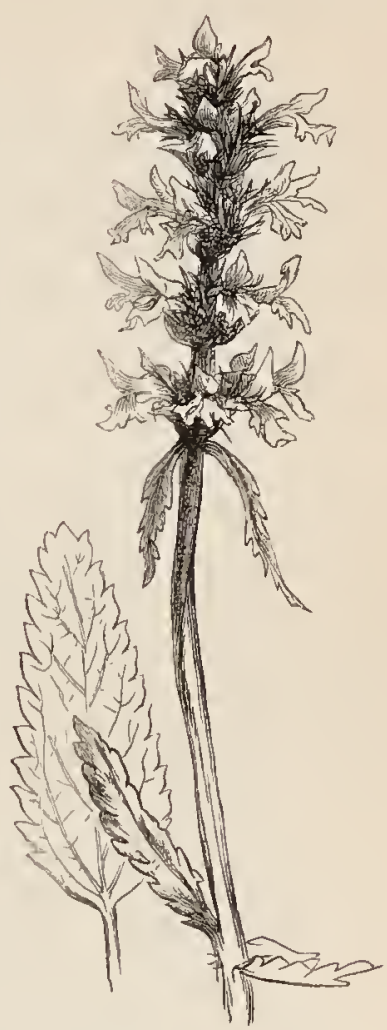

WOOD BETONY. that they are sure to be noted as curiosities by any one finding them.

"Sell your coat and buy betony" was an old 
proverb, intended to represent the great value of the Wood Betony, which was held in great repute, not only for its medicinal virtues, but as a charm against evil spirits. Unfortunately, its virtues are not equal to its repute, as it is a plant common enough in England, though rare in Scotland and Ireland. The Bugle $^{2}$ enjoyed similar repute, but is equally of little value. This is also common in woodlands, with here and there the "Hedge Woundwort," 3 and the pretty yellow Dead-nettle or yellow Archangel. ${ }^{4}$

Of all the plants in this family none are so profuse as the Wood Sage. ${ }^{5}$ The whole plant has a bitter taste, and is said to have been used as a substitute for hops in brewing; at any rate it was formerly employed as a tonic, and probably possesses useful properties in that direction. It is a very sombrelooking plant, with its green flowers and dull sagelike leaves. In some parts of France it is called Ambrosia.

The true Forget-me-not (Myosotis) is an aquatic species-

"By rivulet, or wet road-side,

That blue and bright-eyed flow'ret of the brook,

Hope's gentle gem, the sweet forget-me-not."

But there are similar plants in woods, such as the wood Forget-me-not, which is almost confined to Scotland, and the field Forget-me-not, ${ }^{6}$ which is occasionally met with in woods, but is a poor substitute

Stachys betorica.

2 Ajuga repians.

Stachys sylvatiza.
- Lamium galeobdolon.

5 Teucrium scorodonia.

6 Myosotis arvensis. 
for the flower of "the rivulet or wet roadside." The old story of the drowning knight who cast to his ladye-love a handful of these flowers, exclaiming, "Forget me not," as he was carried away by the stream, is cherished as the poetical origin of the name.

Scarcely less cherished is the Primrose, the memory of which haunts the exile from his native land. As an illustration of this, it is said that 2 living plant was carried over to Australia, where it was publicly exhibited in one of the large towns, and was visited by thousands. Many who saw it then thought little of it in their native land. They were like him of whom it is written-

"A primrose by the river's brim

Or by the cottage door,

A yellow primrose was to him, And it was nothing more."

In towns and villages there is a little plant much cherished by cottagers under the name of "Creeping Jenny," which grows wild by the side of ditches. A similar plant is common in woods, with rather smaller yellow flowers, but the same creeping habit. It is the "Yellow Pimpernel," with the form, but without the romance and poetry, of the scarlet pimpernel or "poor man's weather-glass."

Docks, of course, will assert themselves amongst trees as well as amongst corn, and, consequently, here we meet with the Red-veined Dock ${ }^{2}$ as well as in hedges, and sometimes one or other of the field-

1 Lysimachia nemorum.

2 Rumex sanguineus. 
loving docks, with the common Sorrel, ${ }^{1}$ in open spaces. Plants so universally common could scarce be absent anywhere. Old Culpepper says that all

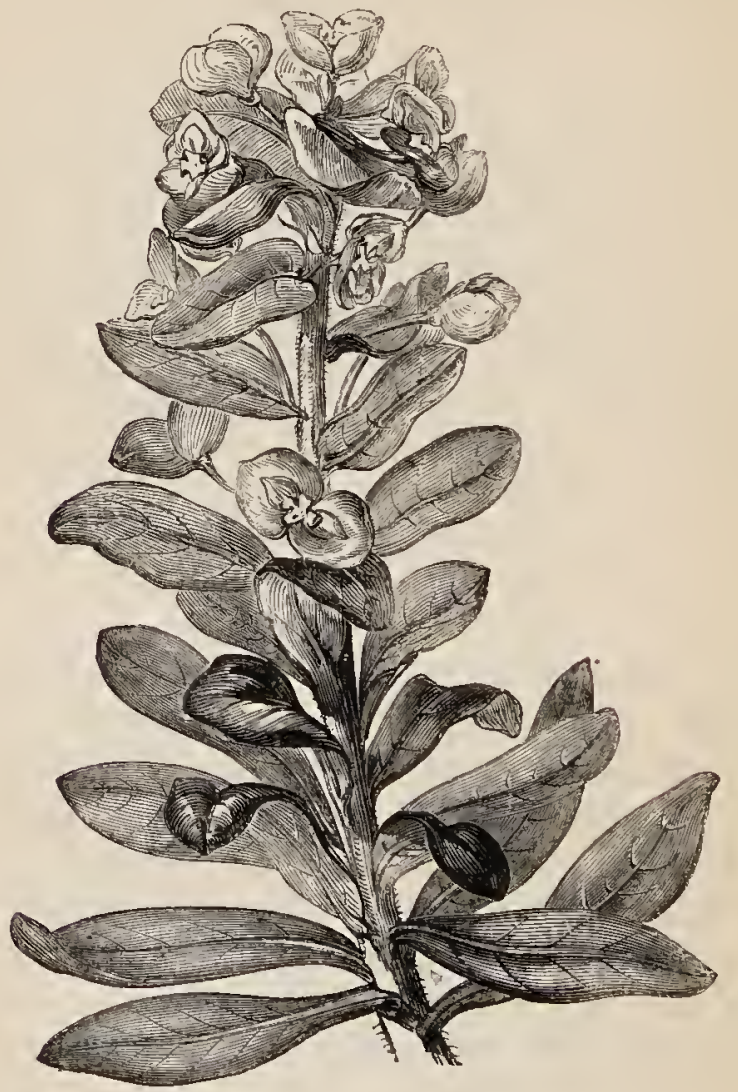

THE WOOD SPURGE.

docks boiled with meat make it boil the quicker. The sorrel appears plentifully during summer in the 
markets of Paris as a salad. It might prove beneficial to our healths, in this meat-loving country, if we acquired a little more of the Continental predilection for vegetables and salads.

The Wood Spurgel is the only spurge usually found in woods: other of the woodland species are all rare. These plants are so filled with a milky juice that wherever broken, or a leaf plucked, the white milk oozes from the wound. This juice is somewhat of the nature of caoutchouc or Indiarubber when evaporated. The dried juice of some of the large Indian spurges is employed to some extent as a substitute for gutta-percha. The milk of the spurges is acrid and poisonous.

The Herb Mercury ${ }^{2}$ often covers large patches several square yards in extent, about a foot high, and not altogether unlike young nettles. Some of the plants are males and others are females, but both grow harmoniously together. If the leaves are steeped in water, they are said to afford a blue colouring matter, somewhat like indigo, but very fugitive. Children gathering flowers may be reminded that nettles will grow in woods. The flowers in mercury and nettles are green, small, and very uninteresting to any except botanists, or those who desire to become such. There is, however, a suggestion of interest in the fact stated above, that in these plants there are separate male and female flowers, and these sometimes on different plants. How do the ovaries become fertilized under "such

1 Euphorbia anygdaloides.

${ }^{2}$ Mercurialis perennis. 
circumstances? Modern investigation has shown that this is accomplished largely by means of the agency of insects. Bees and flies entering certain flowers brush off the pollen and carry it away with them; they enter other flowers and the pollen is left behind, adhering to the stigma. An entire volume of considerable size, teeming with facts, has been written on this simple subject, especially with reference to one order of plants, the Orchids. It is impossible to summarize such a work in a few lines: the conclusion may be thus stated. Insects and other agencies are constantly at work, contributing to the fertilization of plants.

The orchids are plants which abound in damp tropical forests. The flowers have the most singular of forms, often resembling insects; and the structure of them is very peculiar, indeed, so much so, that external agencies are essential to achieve their fertilization. Some orchids are epiphytal, growing upon trees; others are terrestrial, growing on the ground. Terrestrial orchids are the only kinds represented in our flora, and of these several species occur in woods. The flowers are very irregular in form, sometimes with a swreet spicy odour, without any true stamens, but the pollen combined in two compact waxy masses, the roots in many cases furnished with a tuber, which is replaced by a new one every year.

One of the commonest of wood orchids is the Twayblade, ${ }^{1}$ with a pair of leaves, between which rises a spike of small green flowers. Another common 
species is the Spotted Orchis, ${ }^{1}$ with smooth shining spotted leaves, and a dense spike of pinkish flowers. There is also the Purple Orchis, ${ }^{2}$ the Bird's-nest Orchis, ${ }^{3}$ and the Helleborines, ${ }^{4}$ with occasionally one or two others. Many of the species prefer a calcareous soil, and some of the most attractive grow on open downs. They are all interesting and instructive when studied by the light of modern investigation.

The Stinking Iris ${ }^{5}$ is one of the wild representatives of the Garden Iris, or "Flag." It has sword-shaped leaves and purplish flowers. When ripe, the threelimbed capsule splits down each division and exposes the bright red seeds. It is by no means uncommon in the chalky woods of the South, but is rare in the North. The leaves when crushed have a strong odour, which is sickly and oppressive, but hardly foetid.

The curious "Herb Paris" 6 is very local, but it occurs generally in woods. It is one of the plants which, when once seen, will always afterwards be recognized, from its weird and singular appearance.

The sweet little "Lily of the Valley" 7 we have seen extending for a great distance over the ground in some of the Kentish woods and elsewhere.

"The lily-of-the-vale, whose virgin flower

Trembles at every breeze, beneath its leafy bower,"

is sometimes called "Jacob's Ladder" and is considered the type of humility. The fragrance of its fresh blossoms is universally admired, and it is by

1 Orchis maculata.

2 Orchis mascula.

3 Ncottia nidus-avis.

- Cephaianthera.
5 Iris fatidissima.

6 Paris quadrifolia.

7 Convallaria majalis. 
no means surprising that many poets have sung its praises. The larger, but less admired, and less common "Solomon's Seal,"l is sometimes found in woods.

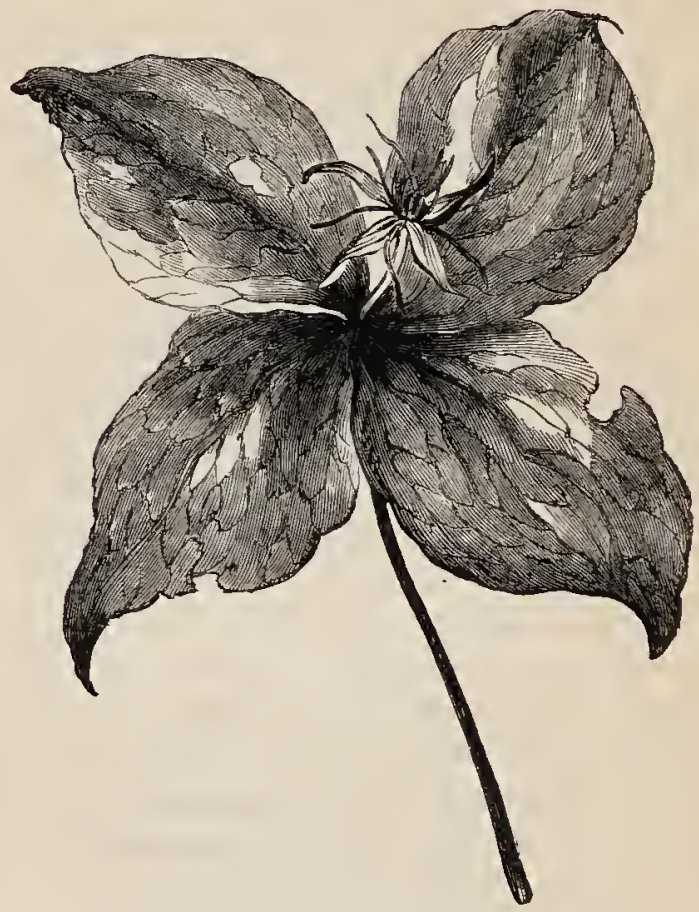

THE HERB PARIS.

The wild wood Hyacinth, ${ }^{2}$ with its drooping blue flowers, is so common and so great a favourite that a spring nosegay of wild flowers would seem imperfect without it. Children will always call them "bluebells," although the Campanula alone merits

1 Polygonatum multifornm.

2 Scilla nutans. 
that name. In spring some woods seem to be carpeted with green and blue from the profusion of these flowers, which deserve always to be associated with "buttercups and daisies" and primroses.

The only wild Garlic we have met with in woods is the Ramsons. ${ }^{1}$ It has a strong odour of garlic, and is said to be a great favourite with the Russians as a seasoning for their food:-

"Eat leeks in Tide, and ramsons in May,

And all the year after physicians may play."

After all these there still remain some plants which have flowers so insignificant that they are not popularly classed with flowers at all, but receive the general and vague designation of grasses. Not that they are all grasses which the popular application of the word includes, but they are grass-like in their appearance and in the character of their flowers. This group includes the rushes, the sedges, and the grasses. The rushes are associated in one's mind with marshes and swamps, but there are what are termed wood-rushes, which have leaves that resemble those of grasses and the flowers of rushes. Two of these may be named as the most common-they are the Hairy Wood-rush ${ }^{2}$ and the Great Wood-rush. ${ }^{3}$ The leaves are fringed with long soft hairs, unlike those of any grass; and when in flower the rigid, erect, branched flower-stalk, not to hint at botanical distinctions, more resembles a rush.

The sedges again resemble grasses in the form of their leaves, but they are more rigid, usually larger

${ }^{1}$ Allium ursinum. " Luzzlla pilosa. ${ }^{3}$ Lusula syluatica. 
and coarser, and more addicted to swamps. The wood Club-rush ${ }^{1}$ reaches the height of three feet in damp comers of woods; the great drooping serge, ${ }^{2}$ with its long pendulous "cat's-tail" spikes is easily recognized; as also the pendulous wood-sedge, ${ }^{3}$ with its looser, more straggling spikes. There are also a few smaller species commonly sylvan in their habits, but offering no special cause for mention.

The true grasses-some of them are the same as are found in lanes and by roadsides, such as the common Cock's-foot, and the sweet-scented vernal grass, ${ }^{4}$ which has the odour of melilot in drying, and, in fact, gives the odour to new-mown hay. Then there will be found the tall Brome-grass $;^{5}$ the rough Bromegrass $;^{6}$ the wood Couch-grass $;^{7}$ the Oat-grass $;^{8}$ the wood reed $; 9$ and the false Brome-grass. ${ }^{10}$ In addition to these will doubtless be the tufted Hair-grass, ${ }^{11}$ and the Soft-grass, ${ }^{12}$ which will not by any means exhaust the list.

Grasses are particularly subject to two kinds of parasites. One consists of a soot-like dust which smothers and destroys the flowering heads, and is known as smut, ${ }^{13}$ common to all the cultivated grains as well as the grasses. The other is a black, hard, horny body, which absorbs and takes the place of

1 Scirpus sylvaticus.

2 Carex pendula.

s Carex syluatica.

- Anthoxanthum odoratum.

5 Bromus giganteus.

6 Bromus asper.

7 Triticun caninum.
8 Arrhenatherum avenaceum.

9 Calamagrostis epigeios.

10 Brachypodiun syluaticum.

1 Aira caspitosa.

Is Holcus mollis.

13 Ustilago carbo. 
some of the seeds, standing out like a spur from the scales of the flower-heads, and is known as "Ergot." These are two of the most common diseases of the grass tribe, all the world over, except perhaps the "rust" and the "mildew," which are about equally common. As for the insectivorous pests of grasses these are almost multitudinous. We can only suggest that the vegetable and animal parasites of the grasses and rushes are so numerous that an entire volume of considerable size might be filled with mere descriptions of them. 


\section{CHAPTER V.}

FERNS, MOSSES, AND LIVERWORTS.

THE cultivation of ferns has of late years become so universal, that it has tended very much to spread a more accurate knowledge of these interesting plants, and at the same time not a little towards reducing the number of plants growing wild of our rarer species. The woodland ferns are in most instances widely distributed species, including the majority of the larger and more imposing kinds. The mountain species are small and comparatively rare. It is the latter which are most suitable for growing under shades and in Wardian cases, for which most of the woodland species are not fitted. Fern spores, analogous to seeds, are produced in capsules, collected in tufts on the underside of the fronds, or leaves. In olden times fern-seed was supposed to possess magical powers if gathered on Midsummer-eve. Grose says, "A person who went to gather it reported that the spirits whisked by his ears, and sometimes struck his hat and other parts of his body; and at length when he thought he had got a good quantity of it and. secured it in papers and a box, when he came home he found both empty." 
Brand narrates the experience of a man who in r793, told him that when young he was often present at the ceremony of catching the fern-seed at midnight on the eve of St. John Baptist. "The attempt," he said, "was often unsuccessful, for the seed was to fall into the plate of its own accord, and that too without shaking the plant." Our ancestors imagined that ferns produced seed which was invisible; hence they concluded that those who possessed the secret of wearing this seed about them would become invisible. Ben Jonson writes,-

\section{"I had}

No medicine, sir, to go invisible,

No fern-seed in my pocket."

No fern is better known than the "Brake," or "Bracken," l which is not only common on heaths and open places, but equally so in woods, so that it is difficult to say in which place it is most plentiful. It is a gaunt, ungainly plant, but when growing in large quantities is not without beauty. The name aquilina is from the Latin aquila, an eagle, because when the stem is cut across there is a dark mark shown on the section, which has been supposed to resemble a spread eagle. In an old English book printed in $155 \mathrm{r}$, this supposition is alluded to : "Peraventure they ymagyne the symylytude of a tode to be there, evyn as we suppose when we cutte the fearnestalke there to be an egle." It has been said that this plant is of no use whatever; but in the North it was formerly the custom to mow it green, and, burn-

1 Pteris aquitina. 
ing it to ashes, make those ashes up into balls with a little water, which they then dried in the sun and made use of to wash their linen instead of soap. It is also certain that they are, even nowadays, employed for packing fruit; and it has been stated on good authority, that apples stored for the winter, when laid upon and covered with bracken, are much better preserved than in any other way.

The male fern ${ }^{1}$ is almost as common, but the plants are less gregarious in their habit. Plants found in woods are seldom so luxurious as those met with in damp shaily lanes. In the latter situations fronds will be seen a yard in length, with a rootstock, formed by the remains of the fronds of previous years, standing up six inches above the ground, after the manner of tropical tree-ferns. Young plants transplanted from woods into gardens, speedily accommodate themselves to the change, and this requires scarcely any attention thereafter.

The female fern ${ }^{2}$ must be sought in damper situations.

"Search for her in the summer woods,

Where rills keep moist the ground."

We have seen it growing at the head of Bala Lake with fronds five feet in length, and thirty to forty in a single tuft proceeding from the same root. It is a much more delicately cut and graceful fern than the male fern, but does not always succeed so well when transplanted. Perhaps none is more given to variation under cultivation. Some of the cultivated varieties are wholly unlike the original. Poets have

1 Lastrea Filix-mas. ${ }^{2}$ Athyrium Filix-finina. 
shown special attention to this fern, and in addition to the beautiful lines of Calder Campbell, which are too long to quote entire, there is a happy allusion to its haunts by Sir Walter Scott :-

"Where the copse-wood is the greenest,

Where the fountain glistens sheenest,

Where the morning dew lies longest,

There the lady fern grows strongest."

Another fern with some external resemblance in its habit to the female fern, is found in damp woods.

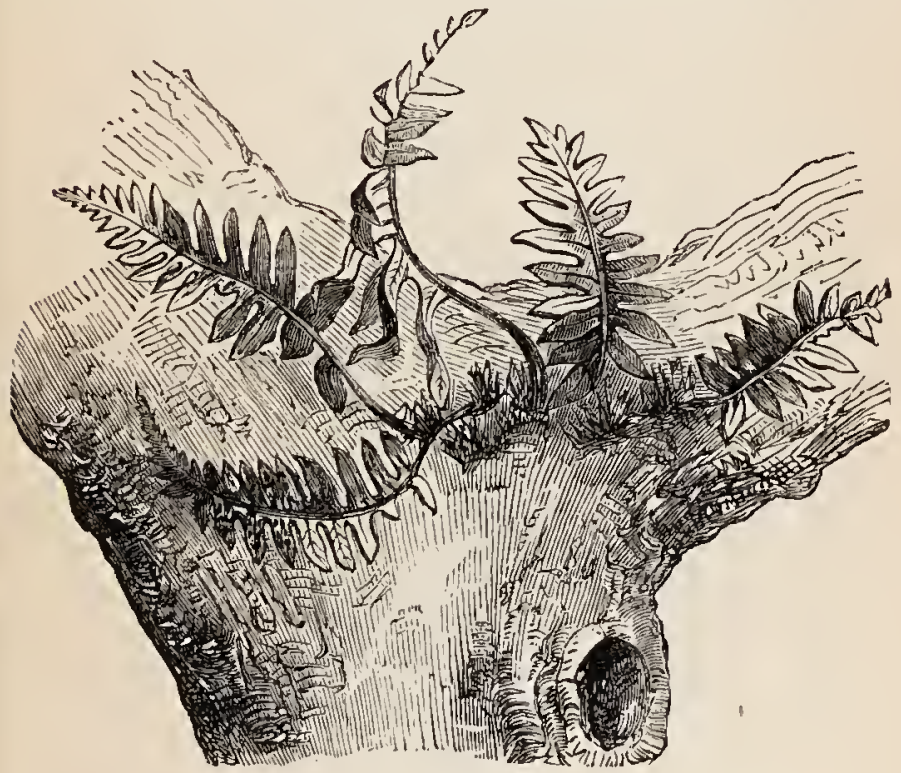

TIIE POLYPODY.

It has no good characteristic common name, but is known to botanists as Lastrea dilatata. It is often found with the male fern, and seems to affect similar localities. 
Less common than any of these is the Shield fern, ${ }^{1}$ both on hedge-banks and in woods. It is quite distinct in its habit of growth, and comparatively smaller.

Of course the common polypody will be seen in old forests and woods on pollard trunks.

The Hart's Tongue, ${ }^{2}$ with its glossy green, smooth fronds, like green ribbons, has sometimes been called the Seaweed fern. It loves moisture, combined with shade, but is very indiscriminate in its choice of locality. In some woods we have remarked it in great profusion, in others scarce a frond could be seen. Up an old wall, down a well, on a bank, under a rotten stump, it would be difficult to name all the possible places for this erratic fern.

The Hard fern, ${ }^{3}$ or Rough Spleenwort, as it was called in olden times, will often retain some of its fronds green throughout the winter. Damp situations in woods, as well as heaths, sometimes furnish this plant plentifully, but it is by no means so successfully transplanted as the Hart's-tongue, and will often die off under cultivation.

Those who would make a botanical collection of ferns must select clean perfect fronds which are fully mature, taking care that they are well in fruit, that is, that the clusters of spores are formed on the under surface. The entire length of the stipe, or foot-stalk, should also be secured down to its point of attachment. These fronds may be dried between sheets of bibulous paper in the same manner as other plants.

3 Polystichum angulare.

3 Blechnum spicant.

2 Scolopendrium vulgare. 
For cultivation, the small or seedling plants should be selected, as these are most likely to succeed; they should be dug up, and not pulled up, with a portion of the soil attached, forming a ball round the roots.

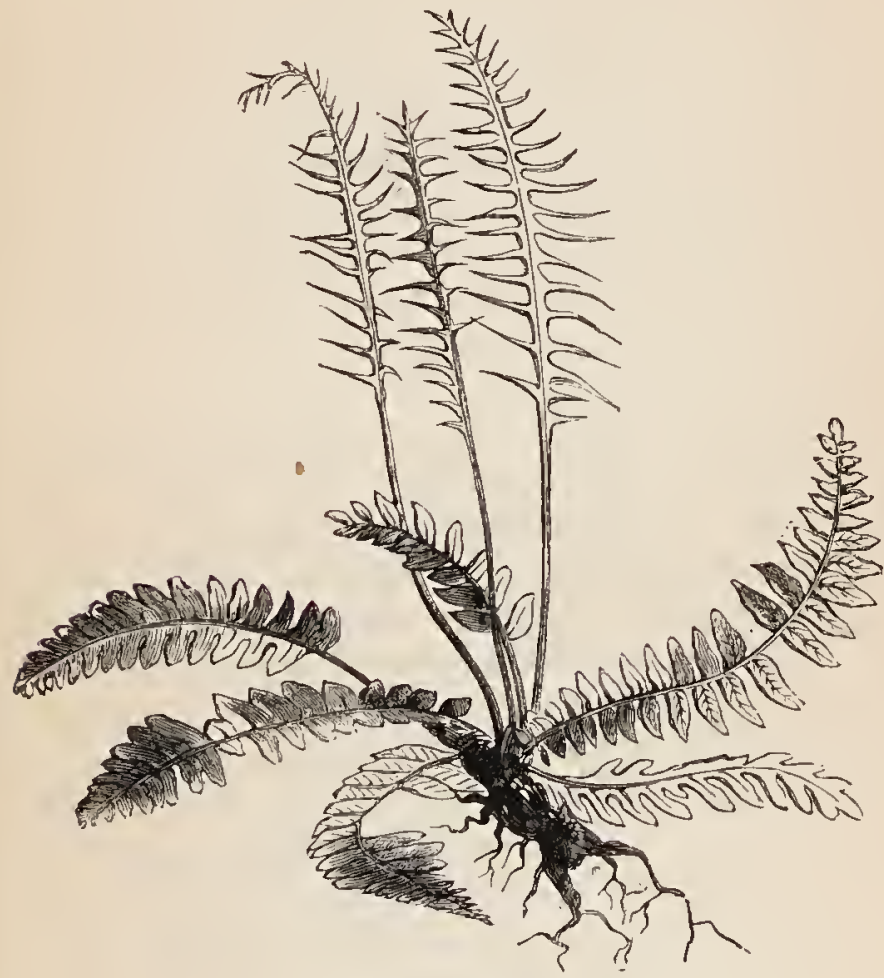

THE HARD FERN,

Lower in the scale of being, but not less beautiful, are the mosses. They may not have so many enthusiastic admirers as the ferns, perhaps because they are smaller, and rather more difficult to determine, 
principally because fashion, that tyrant of modern society, has not yet taken them under protection. Many of them may be cultivated in a similar manner to ferns, but-their time has not yet come.

The fruit of mosses is a capsule, borne at the top of a stalk or stem, which is sometimes almost suppressed, and surmounted by a lid or operculum, which falls away and allows the spores to be dispersed. Some species have a branched straggling habit, others are almost reduced to a rosette of miniature leaves, and these generally gregarious. For all the mysteries of growth, reproduction, and classification, we must refer the reader to the manuals which are specially devoted to this subject.

Hasselquist considers that the wise king of Israel was conversant with mosses, and that the hyssop on the wall of which he discoursed was a small moss still found growing on the walls of Jerusalem. Be this as it may, the smallest or the meanest thing is not beneath the consideration of the truly wise. Pascal observed that "man is placed in the middle between the two infinities-the infinitely great, and the infinitely little-both of which are incomprehensible to him." The microscope has helped him to some knowledge of the latter, but only sufficient to expose still more his ignorance, and convince him of how little it is he knows. The microscope may be requisite to understand the structure and minute characters of mosses, but very much may be accomplished in studying them by the aid of a simple lens.

That earnest lover of nature, John Ruskin, thus writes of mosses: "No words that I know of will say 
what these mosses are; none are delicate enough, none perfect enough, none rich enough-as the earth's first mercy, so they are its last gift to us. When all other service is vain from plant and tree, the soft mosses and gray lichen take up their watch by the head-stone. The woods, the blossoms, the giftbearing grasses have done their parts for a time, but these do service for ever. Trees for the builder's yard, flowers for the bride's chamber, corn for the granary, moss for the grave. Yet, as in one sense, the humblest, in another, they are the most honoured of the earth-children; unfading as motionless, the warm summer frets them not, and the autumn wastes not. Strong in lowliness, they neither blanch in heat, nor pine in frost. To them, slow - fingered, constant-headed, is entrusted the weaving of the dark eternal tapes-

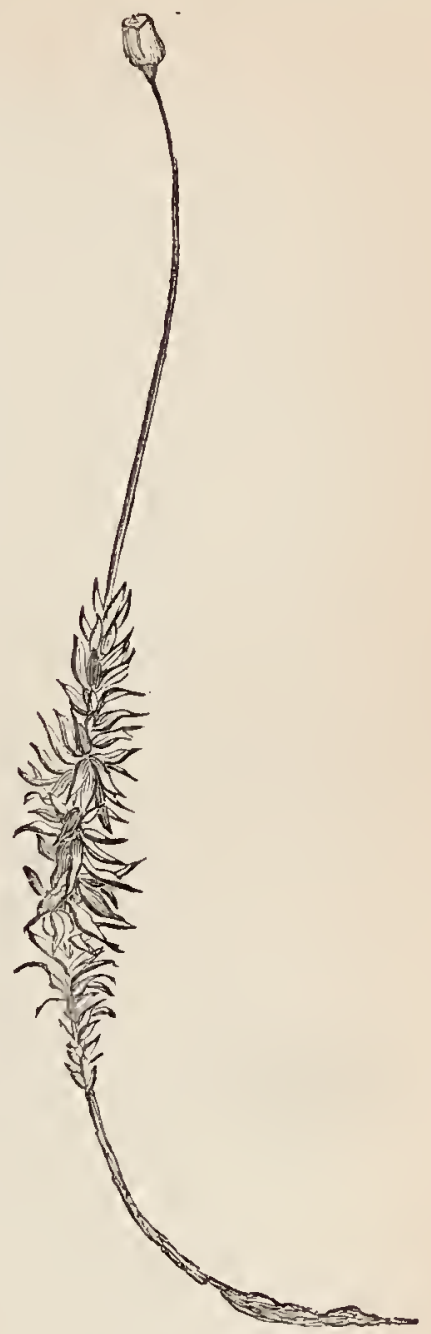

COMMON IIAIR-MOSS. 
tries of the hills; to them, slow-pencilled, iris-dyed, the tender framing of their endless imagery."

One of the first, as one of the largest, most common, and easily distinguished of mosses found growing on the ground in woods is the common Hair-moss. ${ }^{1}$ The simple stems are from a few inches to a foot in length, growing in large dense patches, of a deep green, with narrow sharp-pointed leaves; the prominent capsules standing erect on their long stalks and surmounted by a hood, sharppointed at the top, not unlike an extirguisher. It is much used by the Laplanders for beds ; brooms and dusters have been made of it. The tired wanderer will not despise it for a lounge.

A smaller species with similar general characters is also common in the same localities, which is sometimes called the dwarf Hair-moss. ${ }^{2}$ It does not occur in such large patches, and its botanical name is derived from its supposed resemblance to a miniature aloe.

In these mosses the tops of the stems will often be

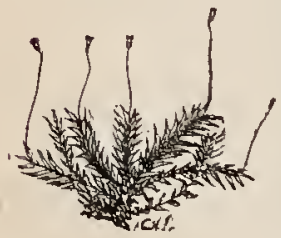
seen to present a beautiful starlike appearance, certain supplementary developments of gemmæ, here and there brightly coloured, which deserve attention and study, but it would take us into too wide a diDWARF HAIR-MOSS. gression to do more than suggest them.

Mungo Park and his moss has been so often alluded

1 Polytrichum commune.

2 Polytrichum aloides. 
FERNS, MOSSES, AND LIVERWORTS.

to, and the anecdote related so many times, that we need not repeat it.

" One tiny tuft of moss alone,

Mantling with freshest green a stone,

Fix'd his clelighted gaze ;

Through bursting tears of joy he smiled,

And while he raised the tendril wild,

His lips o'erflow'd with praise."

This little moss, with its small plume-shaped branches, "frequently of a deep metallic-green colour, are seen reviving under the influence of autumn's showers on almost every shaded clayey bank, as it seems to shun spots that are much exposed to the light. ${ }^{1}$ The interest is increased when, towards the close of winter, its dark green capsules throw off the protecting lid, and display the bright red peristome, closing or expanding according to the state of the atmosphere."

There is another moss, ${ }^{2}$ allied to this in some respects, which grows in extensive patches, but is more common in marshy places than woods. The stems are sometimes four inches in length, but the distinctive characters of these species would be too technical for our present purpose, and it is hardly possible without them to convey an accurate idea of their differences. Nevertheless, the "Broom Moss," 3 is one which is almost certain to attract attention. The dense tufts are yellowish green, and from two to four inches in height. The capsules are mature at the end of summer, chestnut-coloured, and slightly

1 Dicranum bryoides.

3 Dicranum scoparium.

\& Dicranum undulatum. 
curved, the lid being surmounted by a long beak. The long, narrow, pointed leaves are directed towards one side, so as to impart a peculiar appearance, which is readily recognized.

"How glorious are the summer woods,

Where the bright broom fork-moss grows;

With their gush of love-born melody,

And their world of verdant boughs."

The microscope has made many persons acquainted with the capsules of a moss, which are often exhibited to admiring friends by the possessors of that instrument. These capsules are so sensitive to moisture that when breathed upon, the teeth of the margin, called peristome, expand like the tentacles of a miniature sea anemone, and then, as the moisture evaporates, close again. It is sometimes called the "Cord Moss," but in this case it is, perhaps, better known by its scientific name of Funaria hygrometrica, or as the hygrometric moss.

Those scorched places in woods where charcoal has been burnt is a favourite locality for this little moss, which the French consequently call la Charbonnière. The orange-red capsules are pear-shaped, with the mouth turned over on one side, and may be found throughout the summer in such a locality.

The most common of the tufted mosses which grow on the trunks of trees are certain species of Orthotrichum. They grow in round, more or less compact tufts, are often of a dull deep green, and the leaves are very susceptible of moisture when dry, being often curved, twisted, and contorted, but as 
soon as moistened, becoming more or less expanded. In many of the species the capsule is closely seated amongst the leaves, in others it is shortly stalked. The capsules are marked downwards with eight coloured strix, rarely more, and are often very handsome. The most common species has erect flaccid leaves, ${ }^{l}$ rather pale capsules, and a pale green hairy hood at first covering them. In another species the long trumpet-shaped capsule, ${ }^{2}$ with its outer fringe of eight broad reflexed teeth, looks something like the flowers of a minute heath.

The Thyme-leaved moss ${ }^{3}$ is one of the commonest and most attractive of the terrestrial species in damp woods. 'The beautiful bright green of the delicate crisped leaves, its spreading habit, and peculiar appearance are sure to rivet the attention, although it is not common to find it bearing its lisse capsules in this country.

In all the examples hitherto cited the capsules are terminal, that is, produced at the end of the stem or its branches. There are, however, many species in which the capsules spring from the sides of the stems or branches, and these are mostly of a straggling habit, spreading and branching considerably, and consequently presenting quite a different appearance even to the untutored eye.

Two of these species are met with amongst grass in woods, the acute leaves of which are bent back so as to give a rough scaly appearance to the long wiry

1 Orthotrichum affine.

${ }^{3}$ Mnium undulatum.

2 Orthotrichum crispum. 
branches. Though in many respects they are very like each other, they are very different, on account of their rough squarrose habit, from other woodland species.

Others of this family are flattened, with the branches all on the same plane, one imitating on a reduced

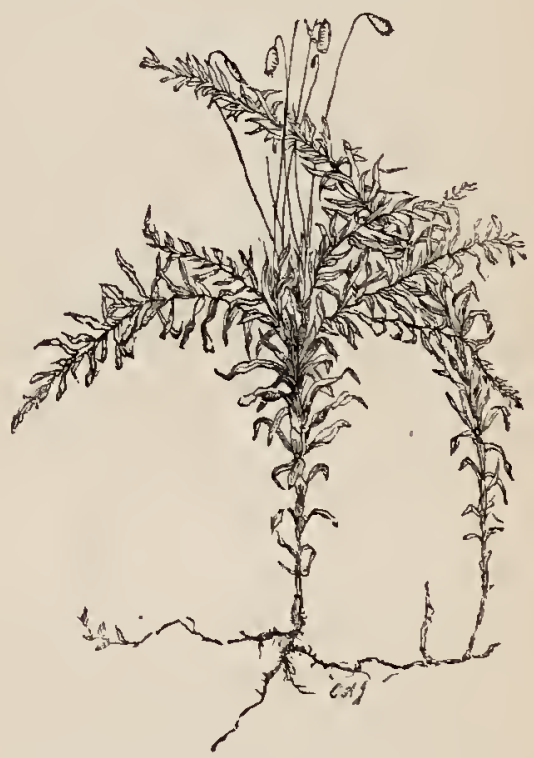

THE THYME-LEAVED MIOSS.

scale the branches of a cypress, another something like a delicate fern, with deeply-cut fronds; others, equally elaborate in their ramification, are glossy, silky, glittering, and are, as far as beauty of form is concerned, the princes of the mossy tribe.

How fruitless is it in a running commentary of this character to give any satisfactory idea of the variety of form, the diversity of character, and yet withal the 
harmony of design which prevail in these small and humble plants. They are without odour to attract, without gaudy flowers to allure, or luscious fruits to entice, not only the pleasure-seeking butterfly and the honey-seeking bee, but even the human lounger in the woods. They appeal not to any power of gratifying the taste or the smell as an apology for existence, but, humbly and without ostentation, perform the task allotted to them in the world. Thus silently, in their myriad forms, scattered from pole to pole, from the burning tropics nearly to the limits of eternal snow, preachers are they, to those whose ears are attuned to their accents, of the wondrous power, the infinite wisdom of the great Father of all.

Under the name of Liverworts, or Hepatica, ${ }^{1}$ a small group of plants, similar in some respects to the mosses, are distributed over similar stations. As with the mosses, so some of these are found on the ground, on the bark of trees, on rocks, beside springs and streams, in bogs, \&c. Some are sylvan in their habits, others belong to moors and open places. The number of species is small, and their omission would hardly be of importance were it not for the fact that the difference of structure in the fruit is such as even to attract the attention of the non-scientific.

Passing over the leaves, and the mode in which they are arranged on the stem, those of the family which occur in woods produce capsules which when matured split into four valves or segments, which fall back, and assume a stellate form. These capsules

1 Hypnum triquetrum and Hypuzm squarrosum. 
contain within them the spores, mixed with thread-like filaments called elaters. These elaters are subject to the influences of moisture and dryness, being formed of spirals, which uncoil or coil under hygrometric

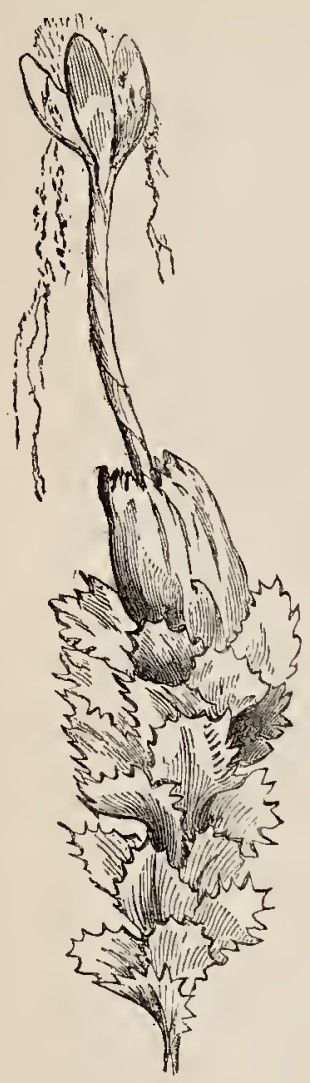

JUNGERMAN NIA. conditions. Their function is probably to aid in the dispersion of the spores.

Such as are found growing on the bark of trees creep along close to the surface, are very much branched, have very thin, delicate leaves, and are not of such lively green as the mosses, but often purplish, olive, and scarcely conspicuous when dry. A little experience will soon enable one to distinguish them from the mosses, even in a barren state, but when the capsules are present there will be no difficulty, for the habit of splitting into four valves is so decided a feature that it will determine the question at once.

There are some of the terrestrial species occasionally found on the ground in woods, but in damp situations, for most of the species are great lovers of moisture. The very singular Marchantia is not a sylvan plant, or we should be compelled to advert to it at some length. The same may be said of the forms known as Riccia and Anthoceros. 
What method may be followed with the mosses and Liverworts to gain instruction, as well as amusement, and convert a woodland visit to some better purpose than a mere idle stroll? What is applicable to the one is also to the other. Mosses should be collected when in fruit, that is, when they exhibit their capsules. In this condition they should be taken from the ground or trees, and each wrapped in thin paper by itself. The locality to be written outside in pencil, with the date. Arrived at home, all mould or extraneous matters should be removed, the specimens laid out flat between sheets of paper, and pressed by a heavy weight until dry. When dried they may be kept in envelopes, to be studied or named at any time. After years of rest, these specimens will not appear to differ from what they did on the day of their collection, except a slight fading of the bright greel colour. Not only will they prove souvenirs of many a pleasant ramble, but if the Iocalities and dates are attached, they will always afford interest to bryological friends, or they will furnish material for fireside study and intellectual amusement during the evenings of winter. 


\section{CHAPTER VI.}

\section{FUNGI AND LICHENS.}

ANY visitor of our woodlands in September and October will at once recognise a peculiar kind of vegetation not observable in spring and summer. This peculiarity consists in the large number of fungi with which the ground is sprinkled in all directions. Some people believe that fungi only make their appearance in autumn, because it is only then that they obtrude themselves upon the eye, by reason of the profusion in which they are produced. It is, nevertheless, a fact that the class of vegetables known as fungi are being developed all the year round, the larger and more conspicuous kinds being in a great measure autumnal. No one can pass through a moist wood in October without being impressed with the profusion and variety of what are commonly called "toadstools," growing upon the ground or on old stumps of trees. It is only the student of these obscure plants who really knows the immense variety which our woods produce; the hundreds of species which make their appearance, flourish for a few weeks, and then disappear, leaving behind scarcely a visible trace of their visitation. No plants depend so much on the character of the season as these; moisture, combined 
with a certain amount of warmth, is indispensable. In seasons wholly favourable their profusion is astonishing, and the artist will find ample work in portraying the diversities of form, and delicate gradations of colour which these organisms assume. In the majority of cases, indeed in all, with a few rare exceptions, the species which are found in woods may be sought in vain elsewhere. It is also a noteworthy fact that some kinds are found growing only in proximity to certain species of trees. Fir woods have fungi belonging to certain particular species; beech woods will produce other and distinct species, and oak woods others again different, whilst a few species will probably be common to all. It has been a popular notion that all fungi have the form of the common mushroom slightly modified, or rather that those only are fungi which have an upright stem surmounted by a cap, as in the Parasol Mushroom, of which our figure illustrates a young specimen. This is a very great mistake, as great as that of a country gentleman who gravely informed us on one occasion that there might probably be six kinds of fungi, but he did not believe there were more; there were the mushroom, the champillion (for champignon), the toadstool, the puff-ball, and the hard things which grow upon trees; he knew no more. Although they do not confess it so plainly, there are many persons whose knowledge of fungi is very little in advanice of this. To them it would seem incredulous that three thousand different species of fungi had been found in the British Isles, and that not less than twenty-five thousand species are scatiered over the face of the globe. 
It is not a very easy task to describe in a few plain words what constitutes a fungus, since with the minuter accuracy of scientific language no such definition yet attempted has been absolutely satisfactory. That they are plants of a low organization is undoubted, growing on the ground, or on other plants as parasites, and obtaining their support from the

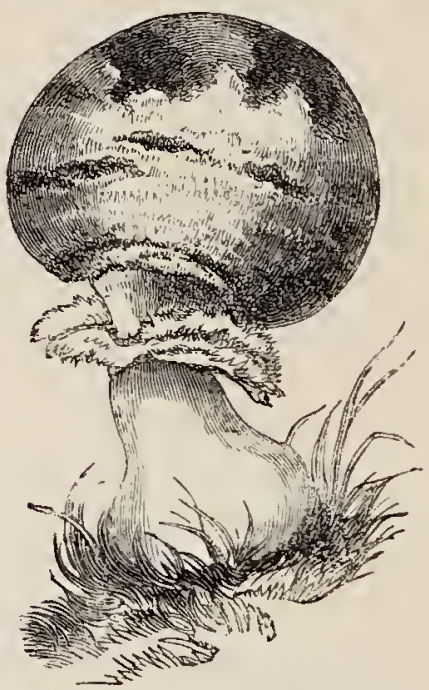

PARASOL MUSHROOM (young).

decay of animal and vegetable matter. It may be accepted as a general rule that wherever fungi are found growing they are in intimate association with, and as the result of, disease and decay. Dead leaves, rotten twigs, and putrid fruits are rapidly disintegrated by the growth of fungi. By this means trees manure their own soil, being assisted in that operation by fungi converting their rejectamenta into vegetable humus, and thus an obscure and little known class of 
plants perform their part in the circle of Nature, confirming good old George Herbert :-

"More servants wait on man

Than he"ll take notice of : in every path

He treads down that which doth befriend him

When sickness makes him pale and wan.

Oh, mighty love! Man is one world, and hath

Another to attend him."

One of the most imposing and attractive of fungi is the Fly Agaric, which grows on the ground in woods. It has a snow-white stem, swollen like an onion-bulb at the base, about six or eight inches high, with a spreading cap on the top, five or six inches in breadth, of the most beautiful and vivid crimson, often with a yellow tint at the edge, and sprinkled over the surface with dirty white or yellowish patches, or warts. Once seen this is never to be forgotten. Most beautiful to the eye, but to the taste one of the most poisonous species that grows; a small fragment being sufficient to produce a kind of intoxication, for which purpose it has long been in use in Kamtschatka, whilst in Southern and Western Europe its use as a poison for killing flies is said to have been the origin of its name of Agaricus muscarius, or Fly Agaric. During the past few years it has been discovered that this agaric, which had for so long a period been supposed to have no higher use than the poisoning of flies, is in reality a most valuable medicinal agent. The poison of the nightshade family and that of this agaric being found to be antidotes to each other, the one may be employed to counteract the other. In other words, the alkaloid amanitine, obtained from the fungus, neutralises atropine, and solanine, the 
poisonous alkaloids of belladonna and other plants of the nightshade family, and vice versâ.

Hunting through the woods in search of the red agaric just named it is exceedingly probable that another fungus will make its presence known by its odour long before it can anywhere be seen. This is well named the Stinkhorn, ${ }^{1}$ for its strong, peculiar, and offensive odour extends for some distance, twenty yards at least, from the object. This fungus grows to six or eight inches in height, and an inch or more in thickness, of an ivory whiteness, surmounted by a close conical cap of a dirty olive colour, or more accurately speaking, covered at the top with a dirty olive, slimy mass, attractive to flies, but with the odour of

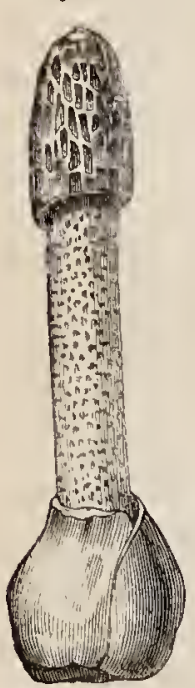

STINKIIORN (reduced). putrid flesh; when this falls away the cap is white like the stem, which latter is punctured throughout its whole length with little holes like a sponge, and is in itself quite devoid of odour. This is also a remarkable fungus; when first breaking through the ground it has just the appearance and size of a hen's egg, the upper end is fractured by the growing stem, which bursts through and grows to its full height during a single night, and soon fills the surrounding air with its fetid perfume. Occasionally this unwelcome visitor makes its appearance in highly-cultivated gardens, coming up near the same spot year by year. Like all very strong odours this is unpleasant

${ }^{1}$ Phallus impudicus. 
in its concentrated form, but when diluted or diffused it is much less unpleasant; indeed, we have heard it maintained that the odour is agreeable, having somewhat that of violets when inhaled at a distance from the centre of diffusion.

Amongst the grass and leaves, beside the narrow paths leading through damp mixed woods, one of the common fungi is the Chantarelle. ${ }^{1}$ It grows on the ground as the mushroom does, but is of a bright orange-yellow colour, like the yolk of an egg. In height it does not exceed two or three inches, and about the same in breadth, but the cap is depressed in the centre, and concave instead of convex, and the margin is lobed, twisted, and contorted, never being so round and regular as in the mushroom. Underneath the cap broad veins run upwards from the stem, in place of the flat gills of the mushroom. In most European countries this brightly-coloured fungus is cooked and eaten; some writers have been enthusiastic in its praise, whilst others deprecate its toughness; at the best it seems to us to be a poor substitute for the genuine mushroom, but it has a most attractive appearance, and should be better

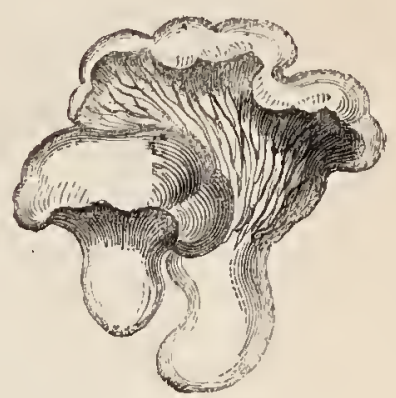
known.

In company with this last, or in similar situations, 
another fungus, usually somewhat larger and more irregular in form, may be found. It is of a dull pinkishwhite colour, of a rather peculiar tint, with a very short, thickish stem and brittle substance. This may be recognised at once by the under-side of the cap consisting not of gills or veins, but being covered with little pointed teeth or spines, packed close together, like the spines of a hedgehog, so that this has been called the "Hedgehog Mushroom." I It may be cooked and eaten, but the flavour is rather strong, which to some palates would be unpleasant. It is noteworthy that this fungus affords an example, in the spiny character of the under-side of the cap, of a group of fungi which botanists call Hydnum, represented by several other less common, or less important species which occur in this country.

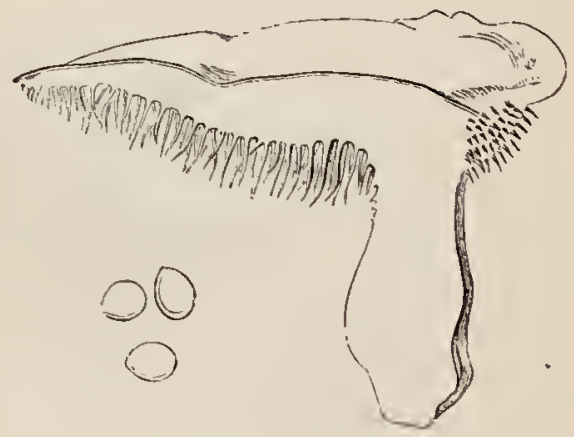

HEDGEHOG MUSITOOM.

It is not unusual in fir woods, or under clumps of fir-trees, to find a little dark brown "Hydnum" grow- 
ing on old fir cones, ${ }^{3}$ which have been for some time lying on the ground. The cap is not much over half an inch broad, placed obliquely on the top of a slender stem about two inches in length, and nearly black. Although it has no ascertained use, this fungus may be sought for as another illustration of that peculiar structure of the under-side of the cap in which the gill-plates of the mushroom tribe are replaced by spines.

It would scarcely be possible within the limits of this work to enumerate half the species of fungi to be found growing in woods in the autumn. All we can hope to do is to point out some of the commonest types of the most important groups, and thus give a general idea of the great variety of form and structure which these little-known vegetables assume. One of the largest of the pileate fungi, that is, such as have an erect stem surmounted by an expanded cap, after the manner of an open umbrella, is called by botanists Boletus edulis. It has no popular nanie with us because its good qualities have never been appreciated. The stem is from three to five inches in height, and from an inch to an inch and a half in thickness, of a dirty-whitish colour, reticulated near the top with minute darker-coloured veins. The cap is sometimes seven or eight inches broad, convex, and of a pleasant nut-brown colour, rather slimy to the touch when moist. Underneath, instead of gills or spines, the surface is even, of a greenish-yellow colour, punctured with myriads of little round holes, as if it had been pricked all over with a pin. To 
comprehend it properly the pocket-knife must be called into requisition, and the fungus divided into two halves, splitting down the stem through its entire length, and through the cap, so that each half shows the outline of its form. By this means it will be seen that the flesh of the cap is thick, through the whole not less than an inch, but whilst the upper half consists of the solid substance, the lower half will be'seen to be composed of little, slender tubes closely packed side by side and that the mouths of these tubes correspond to the pinholes which were observed covering the under surface before it was cut in two. Here, then, we have the gill plates of the mushroom replaced by slender tubes closely packed side by side in a compact mass.

The special interest which attaches to this fungus lies in the extensive use as an esculent which is made of it on the Continent. The tubes under the cap are scraped away, the fleshy substance is cut up into thin slices and dried in the air, and in this form it is sold for domestic use throughout the year. In Austria, and some parts of Germany and France, it is exposed for sale in all the shops where meal, haricots, and other comestibles are retailed. In Vienna it appears in all the smaller shops of the poor localities as one of the regular articles of trade, and its consumption must be enormous. In England it has never stood in high repute as an esculent, probably the most approved mode of cooking has not been adopted, at any rate hundreds and thousands of them flourish and decay year after year, and no one advocates their utilization. 
There are two or three kinds of Botetus less common in woods, with the under-side of the cap either of a blood-red colour, or of a lurid red colour, and these are dangerously poisonous. When one of them is cut down the centre, in the manner just suggested, the flesh almost instantly becomes of an intense blue when exposed to the air.

The habitual rambler in our woods cannot fail to have observed on old trees, certain hard, semicircular excrescences projecting from the trunks, which require some considerable force to remove. The upper side is more or less corrugated, sometimes smooth, sometimes woolly, according to the species, but always firm, except in the young state of a few

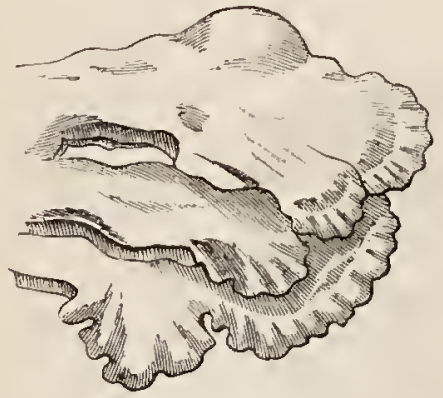

SLLPHURY POLYPORUS.

kinds. The under-surface is punctured with pores, like pinholes, in the same manner as in the Boletus. The substance of these fungi is hard and woody, usually brownish; if cut into slices and well beaten the texture resembles that of soft leather. In Germany two or three of these species of Polyporus are collected in the forests, cut into slices, and beaten 
until softened. In this condition they constitute what is called Amadou, or "German tinder." Warm and comfortable chest-protectors, caps, and other articles are made of this prepared fungus, which was at one time a more important article of trade than now. Not a single species, amongst the one hundred found in the British Islands, has been applied to any practical use.

Looking from the erect trunks to old stumps or prostrate trunks of fallen trees, and we shall be sure to find another fungus, of an ochry-orange colour, either extending in irregular flat patches for some inches, or with the edges projecting nearly an inch from the back, or with a series of these projections

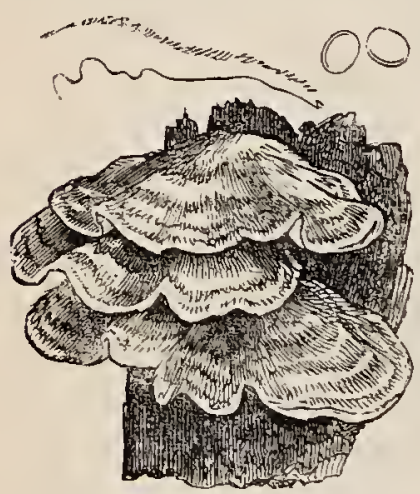

ORANGE STEREUM. one above another, at slight distances apart, for six inches or a foot upwards of the stump. When so reflexed, the upper surface is greyish-ochre and hairy, the under-surface smooth and orange, with a frost-like bloom. The chief interest which attaches to this Orange Stereum, ${ }^{1}$ besides its being really very beautiful and attractive when well grown, is that it is extremely common. It is one of the few fungi which is sure to be found on old stumps all the year round, but in its greatest beauty in the autumn. 
Another less brightly-coloured species is often found in company with it, but in this the under-surface has a tinge of purple. ${ }^{1}$

Turning from the dead stumps for a moment to the fallen branches of an oak, lying on the ground in a state of decay, we shall find that although but recently shaken down by the wind the branch has rotted upon the tree, and may be broken into fragments with the slightest effort. If the weather be moist we shall be sure to find on these fallen branches little black masses of a shaky, tremulous substance about an inch in diameter, with the under surface rough like black crape; but if the weather be dry these will have shrivelled into shining flat patches like blotches of pitch. Placed in water for half-an-hour these shrivelled specimens swell, and again assume the same dimensions and appearance as when in their fresh and growing condition. This is the "Witches' Butter," 2 one of the Tremelloid Fungi; of which several species will be found on dead branches, some in convolute masses as large as the fist, some not unlike mulberry fruit, and some as small as the head of a good-sized pin. They all contain a large amount of water in their composition, so that they shake and tremble like masses of jelly when moist and fresh; but as they become dry the water evaporates, and the fungus shrinks and shrivels almost to a mere film.

It is by no means uncommon to see dead branches lying on the ground, and bearing upon them a

1 Stereum purpureusin.

2 Exidia glandulosia. 
Tremella of a deep yellow colour, sometimes about the size of a filbert, at others as large as a walnut; the surface deeply furrowed, waved, and convoluted, when moist, but shrivelling when dry to one-tenth the original size, and scarcely recognisable. ${ }^{1}$

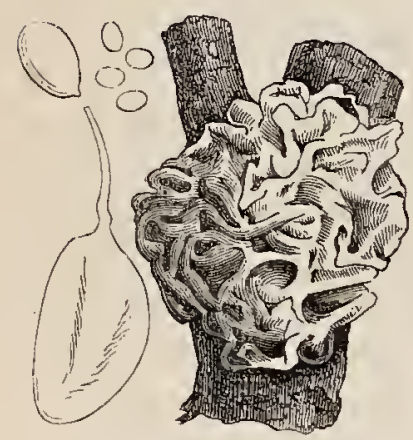

YELLOW TREMELLA.

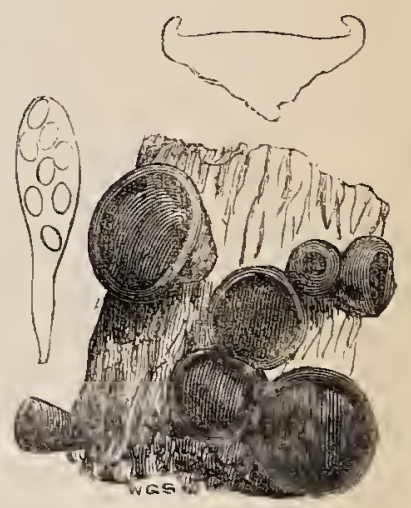

BULGARIA.

It is not unusual to see prostrate trunks of beech and oak when lying in damp situations sprinkled with hundreds of blackish fungi, soft and yielding to the touch, but much firmer than the Tremellas. These bodies range from less than half an inch to more than one inch in diameter, are regularly discoid, like large buttons with a thick stem. Externally they are of a bay brown colour, but the flat disc on the top is of a dull black, and usually in groups of two or three together. The name of black "Bulgaria," which is applied to them, is one which for various reasons is not likely to be forgotten. ${ }^{2}$

1 Tremella mesenterica.

2 Bulgariainquinans. 
On the ground, amongst grass, moss, and dead leaves some very delicate and often beautiful forms. of branched or club-shaped fungi will be observed. The species are numerous, but perhaps the finest and most attractive of common species is the Fusiform Clavaria, which grows in Epping Forest in clusters as large as one's fist; it is of a bright yellow colour, and consists of numerous erect, straight stems, not thicker than an ordinary slate pencil, pointed at the top and narrowed below, where they all spring from one common root. Each of these stems is from two to four inches in length, and brittle, so that if roughly handled they snap in two like threads of glass.

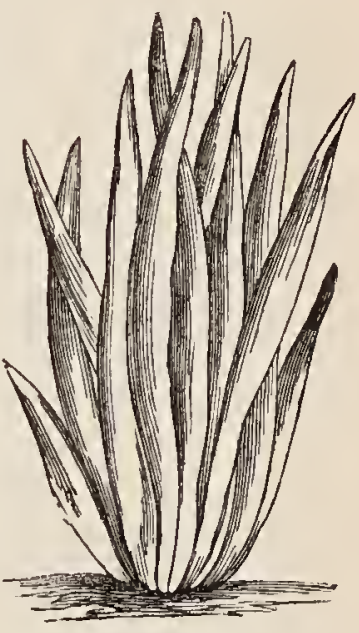

FUSIFORM CLAVARIA.

There are other species which have the stems. very much branched, and often united at the base into one thick trunk. Some are milky white, others the colour of yellow ochre, and others of a beautiful lilac or violet. They are all known by the name of Clavaria.

Whilst looking on the ground for these it is very probable that some curious little cups will be found which would never have been noticed but for close examination of the ground. These little cups will be found in clusters, sometimes a great number of them growing together, not more than from a quarter to. 
three-eighths of an inch in diameter, pale grey, almost white within, and containing three or four little roundish bodies clustered in the centre, like eggs in a bird's-nest. It has been called the "Bird's-nest Fungus" 1 from this resemblance. Each

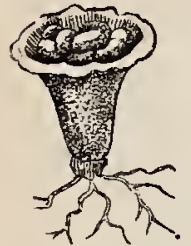
cup is little more than half an inch high, narrowed towards the bottom, and on the outside dark brown, covered with shaggy hair. More closely examined, it will be noticed that the little egg-like bodies are very firmly fixed in the nest, each one BIRD'S-NEST being attached un the under-side by a thin elastic thread. At the first the mouth of the cups is closed, but as they mature so they expand, and assume the bird's-nest appearance. Another species, equally common on dead twigs (Crucibulum vulgare), is smaller, and of a pale olive colour.

Searching for one thing may lead to the finding of another, and instead of the above, some little cups of quite another character may be found. As there are so many species, some not more than the onetenth of an inch in diameter, and others three or four inches, with all intermediate sizes, it is difficult to predict what particular one may be discovered. 'These are called by the general name of Peziza, and may be found, on the ground, amongst moss, upon dead wood, rotten branches, old bark, and even very much smaller ones on dead leaves and the dead stems of herbs and grasses. There is one very beautiful species, with cups spreading from one to two or three 
inches in diameter, of a bright, glowing orange colour, and often twenty or thirty of them growing together within a space of two or three yards. ${ }^{1}$ Watch them carefully, and if it is a bright day, ever and anon a little puff of delicate smoke will be jerked out from the disc; touch them gently with a piece of grass, and another and another puff will follow. These are the spores, or microscopical seeds, forced out in a little cloud, and so it is presumed the species increases its kind.

It would be easy to enumerate many others of the same kind. One dirty white species, not more than an inch in diameter, grows singly on the ground by the side of paths in woods. If scratched, a yellow juice oozes like blood from the wound.2 Another kind, not more than a quarter of an inch in diameter, grows on damp rotten wood and old stumps. The disc is of a beautiful crimson, surrounded by a margin of long, brown hairs. By the side of brooks, watercourses, swamps, gullies, and in the dampest places in the wood, some one or more of these Peziza will be found in spring or autumn, or through the summer, if not too dry. Fir woods invariably afford a neat little species not much larger than the head of a good-sized pin, but growing in companies on the little dead twigs or the larger branches of larch and pine. The disc is of a deep orange, but the margin and outside nearly white, and covered with downy hairs. When the weather is dry the cups will be closed, and the orange disc invisible; but with

1 Peziza succosa.

${ }^{2}$ Peziza aurantia. 
moisture the cups expand, and will be more easily detected.

There is one group of fungi which had well-nigh been forgotten, and these are the Puff-balls. All schoolboys know the "snuff-boxes," as they call them in some districts, and delight to puff them in each other's faces: a dangerous operation to eyes and throat, since swallowing a puff of this dust was nearly fatal to a gentleman in Edinburgh a year or two since. These Puff-balls grow upon the ground, or on old stumps; when young, nearly white and juicy, when old, brownish, and full of snuff-coloured spores.

The great Puff-ball, as large as a man's head, or larger, grows in fields and gardens, and on banks, and when young affords a most delicious meal, after being sliced and fried in butter or fat.

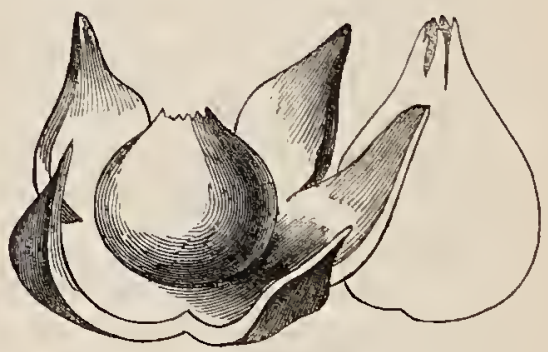

STARRY PUFF-BALL.

The most interesting of the Puff-ball family are the stellate puff-balls. We have collected a hundred of them sometimes in a few minutes, in a small grove of fir-trees. These balls have a double coat; the outer one is thick, and splits from the top in a radiating manner, each segment falling back 
so as to have a starlike appearance, with the little ball, covered with its inner tunic, standing in the centre. When quite ripe this ball is full of snuffcoloured spores, which are ejected from an opening at the top. If the weather proves dry the expanded segments of the outer coat close up again round the inner ball, and in this manner they are blown about and roll about, mingled with dead leaves. Some species are found in fir woods, others under hedges and by roadsides, and others again on sandy banks and hillocks by the sea-shore.

Besides all those larger and more conspicuous fungi which we have named, there are others, and of these a very large number, which the uneducated eye would fail to recognise as belonging to this order. Of this class are the black, pitchy blotches on the leaves of maple and sycamore. No one can have observed trees at all with an intelligent or appreciative eye and not noticed the large black spots, as large as sixpence, on the upper surface of the still green leaves of the maple. During the winter as these leaves lie on the ground and decay, so step by step the fungus matures itself, and in the spring arrives at its final stage. This is not the only fungus which attacks the leaves of trees, for if those of the poplar, birch, willow, goat-willow, and sometimes the oak, whilst still green or just fading, be examined on the under-surface, the yellow spores of a Uredo will be seen scattered over them like a golden dust.

After the leaves have fallen from the trees, and whilst lying on the ground undergoing decay, they will in this condition nourish almost innumerable 
species of fungi, some of them so minute that they cannot be seen by the naked eye,-species of Sphceria, of minute Peziza, or of Phacidium or Discosia, and many others,--fully to comprehend which the microscope must be employed, when it will not be impossible to detect as many as a thousand individual fungi, each complete and perfect in itself, and containing more than a hundred spores, and all growing upon a single dead oak-leaf. The more closely and more intimately we examine these minute species by the aid of a microscope, the more are we astonished at the wonderful work. A small Peziza no larger than a pin's point, with cup and stem covered with delicate hairs, has a perfect reproductive system, asci, sporidia, and all its organization as complete as in the large specimens we may have gathered from the soil, and measuring from three to four inches in diameter.

Not only the leaves, but nearly every dead twig, rotten stick, stem of herb, tuft of grass, has its parasite, its little fungus flourishing upon its decay. Whether in the garden, the orchard, or the wood, one is sure to see little twigs, covered with pink pustules, bursting through the bark, and standing up like little knobs, not so large as a grain of mustardseed. This is one of the most common of minute fungi, ${ }^{1}$ and its history is elaborate and instructive. Yet this is only one of hundreds of minute fungi furnished by the dead twigs of trees and shrubs of all kinds, so that we are justified in saying that for every large fungus which the unaided eye can detect

1 Tubercularia vulgare. 
and recognise, there are ten, nay, a hundred, of the minute microscopical forms which demand the use of the microscope for their investigation.

It may be added that, as a rule, fungi do not grow on the bark, branches, or twigs of living trees. It is only in very rare cases that fungi are developed in that condition, and it should be borne in mind when hunting for them in a wood that growing trees, and branches recently cut and sound, will not afford fungi, but they will furnish lichens, of which anon. Fungi are the consequences of decay and putrefaction. Wherever there is a close, damp atmosphere, which fosters decay, there will be found the mould and the mildew. In this instance we have death, decay, resurrection into a new life, illnstrated in the new forms and new species which succeed and flourish upon the disintegrated and crumbling remains of forms that have passed away.

There is still another kind of vegetation, of a humble character, but still different from anything to which we have referred, and sufficiently common all the world over not to permit of exclusion. These are called Lichens, and although some people may still be found who call them "a sort of moss," such errors are becoming comparatively rare. There is a crude sort of rhythmical description of them in the lines,-

"Some are reddish, some brown, some grey, and some black. And they're pucker'd, edged, button'd, or fringed, front and back ;

Some are lying like leather close under your feet, Some waving from trees in the forest you'll meet." 
The variety of form is so great as almost to baffle any general description. That which is applicable to one group is not applicable to another. Sometimes they so closely resemble forms of microscopical fungi as to puzzle botanists themselves. The fruiting organs are usually a kind of disc, or flattened cup, seated on a thin leathery substance, often corrugated, but without veins, and more like a piece of seaweed than a leaf or a moss, or sometimes without any apparent substratum.

For instance, "old man's beard," I or "beardmoss," is found on old forest trees, especially firs, of a greyish, or greenish-yellow colour, forming shaggy tufts. Each filament is branched, and these branches have secondary thread-like branches throughout their entire length. The cup, or fruit-bearer, is surrounded by a fringe of similar threads. In olden times its use was extolled in medicine; in modern times the birdstuffer uses it to decorate the stumps and twigs, on which his birds are perched.

The "Horse-tail Lichen,"2 hangs also in tufts on the branches of old fir-trees, but the filamentş are thinner than in the last, much divided, and interlaced, but without the bristling side-shoots of the "old man's beard." The cups are rarely met with, small, and not fringed. The common conditions of this lichen are rather. like tufts of hair when seen hanging from the boughs. With closer examination this resemblance vanishes.

The boughs of old ash-trees, ${ }^{3}$ as well as the trunks,

1 Usnea barbata.

- Cornicularia jubata.

${ }^{3}$ Ramalina fraxinea. 
and those also of the oak, nourish another tufted lichen. The filaments are broad and strap-like, flattened, notched, lobed, or slightly branched, and nearly of the colour of the bark. The cups are either scattered over the filaments, or at the tips of the lobes or branches. These are rather large, smooth, and darker coloured. This lichen varies considerably in its general appearance.

A much more mealy form, found on forest trees, ${ }^{1}$ has the filaments narrower, very much divided into pointed segments, with the cups much smaller, and rarely developed. It has been stated that this lichen is very palatable when eaten with salt : although one of our commonest species, no one seems to have been induced to try the experiment. Some lichens are edible, as, for instance, that called "Iceland moss," which is not a "moss," but a lichen; and during voyages to the north polar regions, explorers have had to eke out their food with such lichens as they could find, under the name of rock tripe. In Iceland, and other northern countries, lichens are frequently eaten in times of scarcity. The "Iceland moss" and "reindeer moss" (another lichen) are both found in the British isles.

The "ash-coloured Ground Lichen," 2 is even now sold by herbalists; it was formerly celebrated as a cure for hydrophobia. It has a membranaceous frond, or thallus, which spreads on the ground, of a greyish colour, whitish beneath, and giving off little fibrils resembling rootlets. The margin is rounded and
R. farinacea.
- Peltigera canina. 
lobed, bearing the brownish, flattened fruit-cups at the edge. This has quite a distinct appearance from the tree-loving species above cited. Instead of filaments, the vegetative portion consists of a broad leaflike expansion, lobed like an oak-leaf, and turned up at the edges. Most lichens have a peculiar odour, which this also possesses, and its texture is tough and leathery.

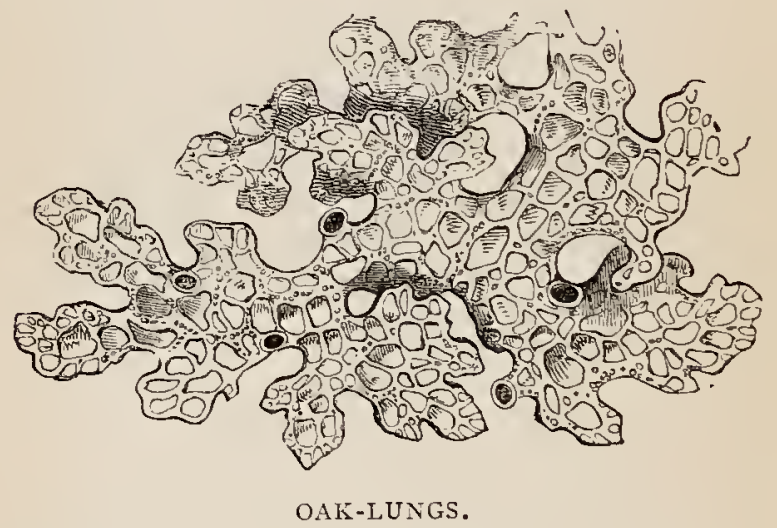

A larger foliaceous lichen growing on old trees is called "oak-lungs" 1 It is rather of an olive colour, very much reticulated, or veined in such a manner as to leave depressions or pits all over the surface. This was called "Lungwort," or "oak-lungs," on account partly of its supposed resemblance to lungs, and partly from its alleged virtues in lung diseases. It contains a bitter principle, which has been used as a substitute for hops. A Siberian monastery once acquired a celebrity for its beer, which was flavoured with the "bitters" of oak-lungs. In addition, it has

1 Sticta pulmonaria. 
been employed by the peasantry of Scotland and Ireland as a domestic dye-stuff for stockings and yarn.

We have lichens of still another form, which is represented by the somewhat rounded bright-yellow patches which adhere closely to barn-doors, old rails, appletrees, and the trunks of various forest trees. ${ }^{1}$ In this instance the thallus, or leaf-like stratum, is more or less rounded at first, but often confluent and irregular, adhering closely and firmly, with the surface raised in warts and folds. The cups are darker coloured, freely scattered over the surface. There are many lichens of this type; some are greenish-grey, some bluish-grey, some brownish. The cups, too, are different in colour, sometimes with very bright tints. Having made the acquaintance of the wall lichen, any of these forms will at once be recognized as lichens. Even at the present day some lichens are still marketable commodities as affording a dye, but the discovery of aniline dyes has much restricted their use.

The thallus, or substratum, is reduced in some lichens to merely a powdery white patch on the bark of trees, and upon this the fruit-cups are seated. These latter no longer retain the form of cups, but become elongated, and closed above, with a

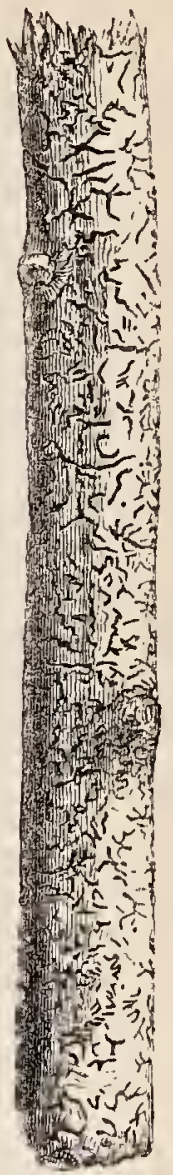

OPEGRAPHA SCRIP'IA. 
narrow slit down the centre. Two or three ${ }^{1}$ of the common species are found on oak, beech, elm, ash, birch, holly, \&c., and are a transition series to another group, in which the powdery stratum is so thin and delicate that, if present, it can scarcely be seen. The fruit-cups are entirely replaced by long, narrow, thin, and fantastically curved and branched raised lines, with a slit down the centre. ${ }^{2}$ These often resemble the characters of Oriental writing, and most of their names contain some allusion to this peculiarity.

There is only one other lichen to which we are able to allude. It is one which is found on dead wood, and the substratum is not distinguishable. It consists of little, erect, hair-like black stems, with a round black head at the top, and resembling small black pins thrust into the wood, with the heads exposed. These heads contain the spores, as in some other forms they are produced in cups, and altogether so small as scarcely to be seen by the naked eye. ${ }^{3}$

As we have now done with the plant-life of the woods, let us end with lines which but repeat in poetical language what we have urged in prose :-

"Not a plant, a leaf, a flower but contains

A folio volume. TVe may read, and read, And read again, and still find something new, Something to please, - something to instruct, Even in the noisome weed."

' Ofegrapha. $\quad{ }^{2}$ Graphis. $\quad{ }^{3}$ Calicium. 


\section{CHAPTER VII.}

\section{QUADRUPEDS.}

MANY generations have passed away since the larger carnivorous animals inhabited these islands. History gives us but slender information of the reign of the brown bear. Pennant says that there is proof of their infesting Scotland so late as the year 1057 , when a Gordon, in reward for his valour for killing a fierce bear, was directed by the king to carry three bears' heads on his banner. More recently the wolf flourished in Scotland, for Hollingshed states that it was noxious to the flocks until 1577 , and was not entirely extirpated till about $\mathbf{6} 680$. Ireland was not delivered from them for some time after this, since the last presentment for killing wolves was made in the county of Cork about the year I 7 Io. As to the wild boar, that also disappeared at a remote period. At the time when a vast forest grew on the north side of London, it was the retreat of stags, fallowdeer, wild boars, and bulls. Hunting the wild boar was a sport protected by the Norman kings; and Charles I. tried to restore the sport by the introduction of wild boars into the New Forest; but these were soon extirpated. Amongst the extinct British 
animals the beaver should also be mentioned. Giraldus Cambrensis, in his itinerary through Wales in I 88 , says that in his time they were only found in the river Teivi. Pennant saw two of their supposed haunts, "one in the stream that runs through Nant Frankon, the other in the Conway, a few miles above Llanrwst."

These records of the last of a savage race bring to mind many a romantic story and interesting legend in which they performed a part. Such stories linger about Wales, Scotland, and Ireland, more than England. The traveller in Wales will not fail to hear the narrative of Llewellyn and his dog, and the wolf still flourishes in the legends of Scotland. The last English wild boar's head smoked on the baron's Christmas table many centuries ago, and the last wolf was decapitated in times now remote, yet we are ever and anon reminded of them in our Christmas customs and nursery tales.

The largest of our indigenous wild animals, which frequent woodlands, is the Fox, and the protection which this creature has enjoyed for the sake of sport, has had much to do with its preservation. All other circumstances taken into consideration, exclusive of this, and "Reynard" would have been extirpated long ago. Its distribution is very variable in different counties; in some it is very rare, in others equally common, in proportion to the protection it enjoys. This well-known animal lives in woods and thickets, keeping itself concealed during the day, and sallies forth at night in search of prey. Its favourite food is partridges, grouse, rabbits, and leverets; the farmer 
knows, to his cost, its predilection for poultry; and smaller birds and quadrupeds fall victims to his hunger when the larger fail. The cunning of the fox is proverbial, and so also its odour; and Pennant says that it is a great admirer of its bushy tail, with which it frequently amuses and exercises itself by running in circles to catch it, and in cold weather wraps it round its nose.

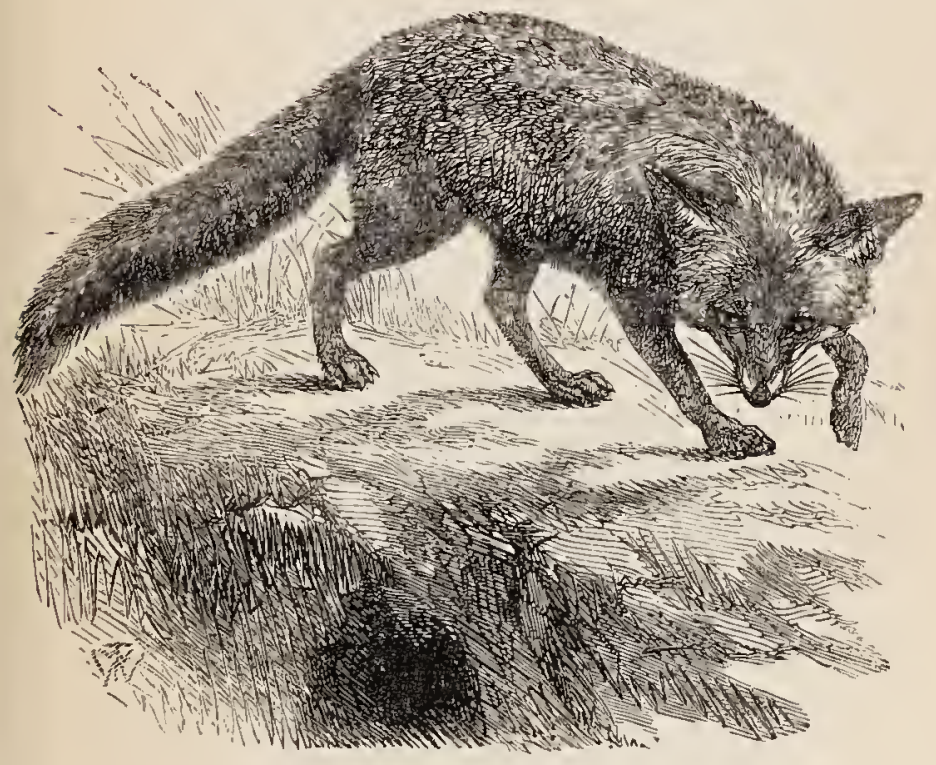

THE FOX.

Charles Waterton writes of this animal: "Common opinion seems to concur in attributing to the fox an extraordinary amount of cunning--' as cunning as a fox,'-still $I$ am not prepared to concede this prerogative to the fox alone, as I am acquainted with 
many other animals capable of disputing the prize with it. Once it so happened that Reynard (and possibly some members of his family) had made an excellent supper on an unprotected flock of fine young turkeys about half-grown, - eight of these were missing the next morning. It seems that, after the four-footed thief had satisfied his call of hunger, he naturally bethought himself that his wife and children would like a bit of turkey for supper on the following night ; so he buried five of the remaining victims in an open garden which was close by. Now, if the simpleton had covered them all over with the soil on the garden bed, I would have given him credit for superior sagacity, but he actually left one wing of each bird exposed to view, and it was this exposure which led to their discovery. An ass in such a case would have shown just as much talent and cunning as Reynard had here exhibited.

"In early youth I would often mount into a fine old oak-tree on a moonlight night to watch the foxes at their vesper pastime. Thus seated aloft I could see the cubs as playful as kittens, catching each other by their brushes, now standing on three legs as if in the act of listening, then performing somersets, sometimes snarling, sometimes barking, and often playing at a kind of hide-and-seek, as we used to do when I was a lad at school."

Much more rare is the Badger, which is equal to the Fox in size, but more clumsy and retiring in its habits. Badger-baiting was one of the cruel pastimes of a more barbarous age; but since its abolition we seldom hear of the badger except in association with 
the "badger hair-softeners" employed by artists. In a few more years this will probably become extinct as a British wild animal. It is a sluggish, indolent creature, which conceals itself during the day in a burrow excavated in some quiet corner of a wood or thicket, coming out in the evening to feed on roots, fruits. insects, or small animals. It is said, that if taken young it may easily be domesticated, but never become a very desirable companion, as it possesses an odour not entirely agreeable.

By far the most common, vivacious, and interesting of woodland quadrupeds is the Squirrel. From childhood it is familiar to us, whirling round in its little wire cage, and cracking nuts; but the poor little creatures we are accustomed to see under confinement are satires upon the free, uncaged squirrels leaping from bough to bough, scrambling along the branches, scampering up and down the trunks and gambolling in their native woods. The squirrel is very fond of nuts and acorns, yet there are many other things which compose its bill of fare when nuts and acorns are not to be found. It is entirely a vegetable-feeder, and the young succulent shoots of trees and shrubs furnish it with many a meal. Perched upon its haunches, its long bushy tail turned on its back, it sits erect, holding the filbert or acorn in its paws, cracking and divesting it of its shell in as leisurely and methodical a manner as monkeys perform the same operation. Its nest is usually built near the top of a high tree, and is nearly as large as a man's head, formed of moss, leaves, and twigs, with a hole at the side for ingress 
and egress. Naturalists say that squirrels are provident animals, never leaving their food to chance, but

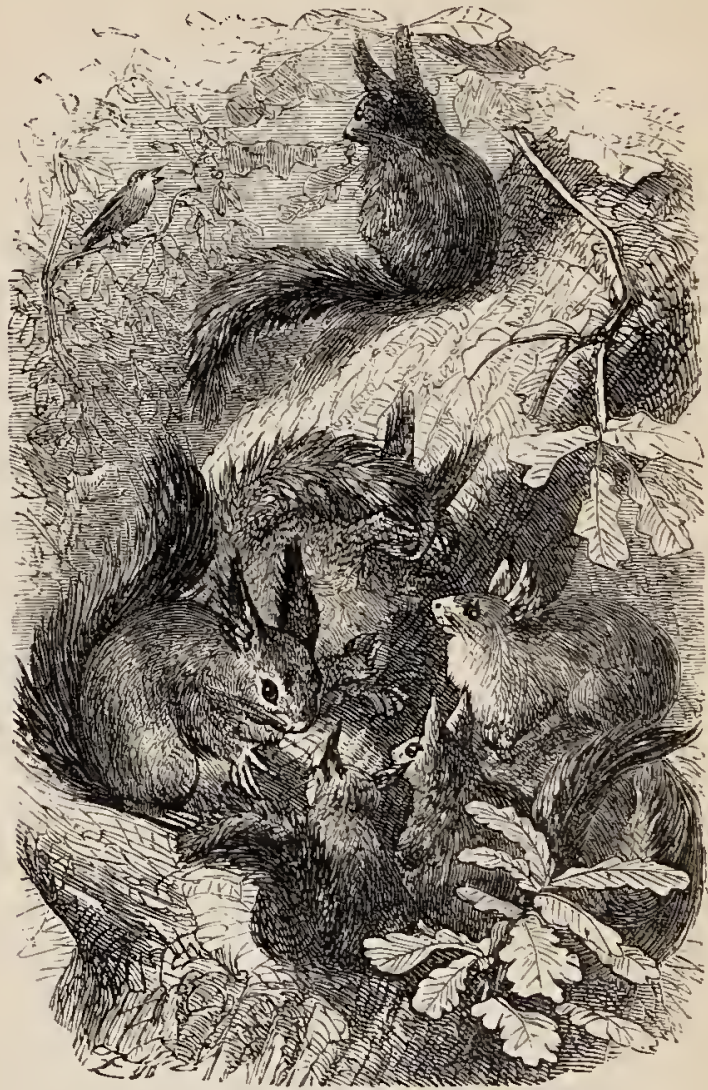

TIE SQUIRREL.

securing in some hollow tree a vast magazine of nuts for winter provision.

In some respects the little Dormouse ${ }^{1}$ resembles

1 Myoxus azellanarizs. 
the Squirrel, but it is very much smaller and not so nimble. Its aspirations are not so high, for it builds its nest in the hollow of a tree or in some shrub near the ground. This nest is nade of entwined grasses mixed with leaves, with an opening so contrived that it is difficult to be seen. This little animal retires to rest during the depth of the winter, but in the autumn it stores up in the vicinity of its nest a little magazine of nuts and seeds to await its wakening in the spring. The Dormouse is more common than

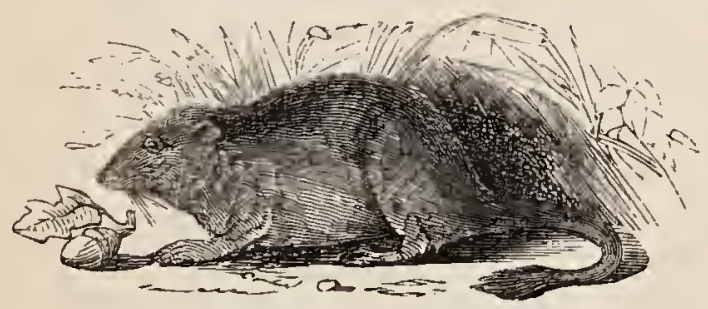

THE DORMOCSE.

many suppose because it is so seldom seen. The cause of this may be found in its being nocturnal in its habits, sleeping during the greater part of the day, and only issuing forth in the evening. For this reason it is rather an uninteresting animal in confinement, rolled up like a ball throughout the day, and hence remarkably sleepy and sluggish as compared with the squirrel. Under such circumstances its nest is much less artistic than when constructed in a state of nature; it seems to comprehend that in its changed condition less severe cold has to be provided against.

The Hedgehog is another nocturnal animal, of timid and retiring habits, not unusually domesticated in 
town kitchens, in order that it may war upon the profusion of cockroaches which flourish in those localities. Under such circumstances the Hedgehog is omnivorous. Insects of all kinds, scraps of meat, fragments of cheese, bread, fruits, worms, nothing seems to be refused. The Rev. Leonard Jenyns gives an interesting account of a hedgehog's meal :"I fell in with one," he says, "in a sheltered part of the garden, which I was enabled to watch unobserved, and which afforded me an opportunity of seeing a little into its habits and mode of feeding. It was creeping up and down a grass walk apparently in busy search for.worms. It carried its snout very low, insinuating it among the roots of the herbage, and snuffing about under the dead leaves which lay about. After a time it commenced scratching at a particular spot, to which it seemed directed by the scent, and drew out a very large worm from just beneath the surface of the ground. This it immediately began to devour, taking it into the mouth by one extremity, and gradually eating its way to the other, an operation which lasted some time, and was attended by an incessant action of the teeth, which grated upon one another with a peculiar noise. After the worm was. gone, as I thought, I was surprised to see the whole put out of the mouth again, and, from the appearance of the cast, I was led to believe that it had been only subjected to the action of the teeth, for the purpose of being bruised, and squeezing out the soft internal parts of the body, which alone were eaten in the first instance ; the skin itself, however, was shortly retaken: into the mouth and the whole clean devoured." 
This helpless little creature has no means of defending itself from its persecutors except by rolling itself in a ball, and thus presenting nothing but spines to their attacks. It runs rapidly, keeping up a peculiar low gurgling sound, but becomes silent at the slightest alarm, and prepares to make a ball of itself should the necessity arise. During the winter it envelops itself in leaves, and lies in a state of torpidity until the spring. In a state of captivity it exhibits some traits of domesticity. Our "Bobby" responds to a call by its peculiar gurgling sound, and makes its appearance at meal-times, especially at supper, in expectation of its customary bread and butter and draught of milk. During the day it sleeps, retiring from the light, and wrapping itself in any cloth or soft cushion under which it can hide, but scratching and remaining very restless unless some covering can be found.

The Mole is very common in woods; some naturalists believe that they are more common in such places than in open fields; still we can scarcely regard them as woodland animals.

There are, however, two or three animals of carnivorous propensities, which, from their savage predatory natures, are little better than miniature wolves. The first of these is the Polecat or Fitchet, a common inhabitant of woods and plantations in all parts of the country. It is a sleek dusky-brown animal of the Weasel kind, about eighteen inches in length, exclusive of the tail, and is possessed of an odour so disagreeable as to have passed into a proverb. Its favourite food is rabbits, leverets, poultry, and even 
eggs. Bewick says that it will attack eels, of which eleven were found in the retreat of one of these animals. When the Polecat finds its way into a poultry-yard, it commits great depredations; not content with killing as much as it requires for food, it slaughters everything within its reach, and is in

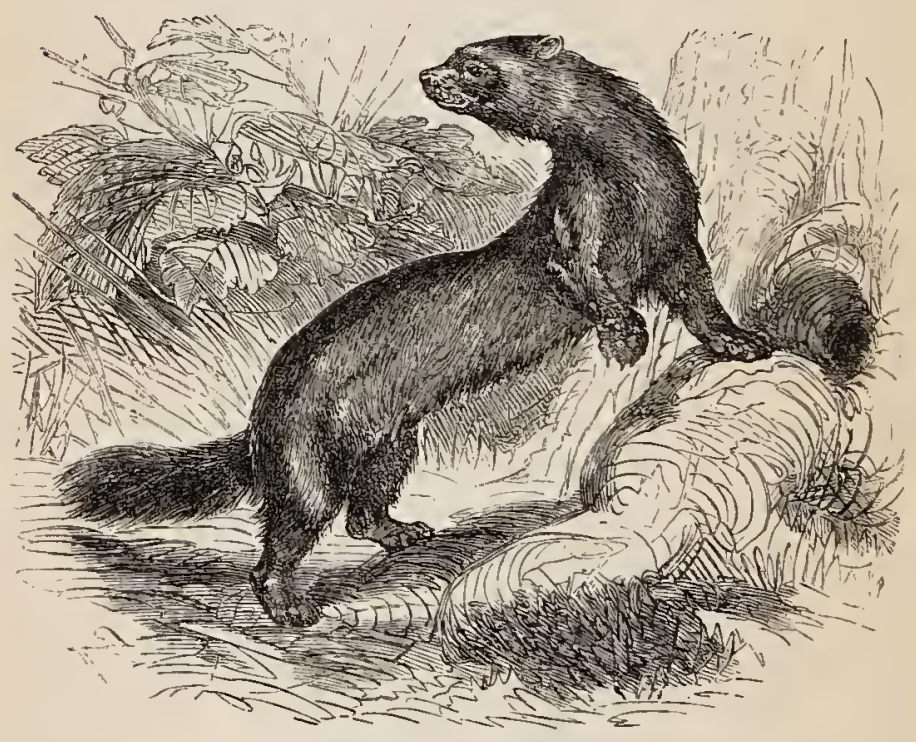

THE POLECAT.

reality the most bloodthirsty of all our indigenous animals. When attacked by man, and without chance of escape, it will fight most savagely for its life, and attack him in return unless promptly prevented. The one redeeming feature in the character of the Polecat is its enmity to rats and mice. Gamekeepers generally condemn it in unmeasured terms; and it is one of the animals which they delight to exhibit amongst 
their trophies nailed to a tree, or against a barndoor.

Smaller than the Polecat, but equally active and courageous, is the Stoat or Ermine, although less confined to thickets, and rather an animal of the heath or moor than of the woodland.

Similarly, the Weasel is found in woods in common with other places, such as hedges, stackyards, and the vicinity of human habitations. It is smaller than the Stoat, and preys principally on mice, moles, and small birds. Both the Stoat and the Weasel will climb trees in pursuit of birds. Many anecdotes are related of the boldness of these little creatures. One day in June, says a writer in the "Zoologist," as a lady was sitting in a room at Ilford, the window of which opened to the ground, she was very much surprised by the appearance of a weasel, which, after trying round the window for an entrance, stood up on its hind legs against one of the panes of glass, and remained there, notwithstanding the furious barking of a little terrier that was in the room, until the window was opened, when he started off very leisurely, but was overtaken and killed by the dog.

"One evening in summer," Charles Waterton tells us in one of his charming essays, "I sat down on a lonely bank near a plantation. A full-grown rabbit made its appearance. It took a circuit of nearly ten paces and re-entered the plantation. Scarcely had it disappeared from view when a weasel came out upon its track and followed scent with the sagacity of a hound. The rabbit soon came out of the wood again in violent agitation, and quickly returned to cover. Out came 
the weasel a second time, and followed up the track with surprising assiduity. The rabbit took cover once more, but it was for the last time; for scarcely had it proceeded a dozen yards ere I saw that all was over. It stopped short, and panted for breath, as though its heart would have burst through its ribs, and then it began to squeal most piteously. It never took another step to save its life, but sat down on the grass, still continuing its wailing. The weasel bolted from the bushes and jumped upon the rabbit's back, inflicting a death-wound on its prey by biting it just behind the ear. I was sitting still at the time, and could easily have despatched either the rabbit or the weasel, but I did not interfere until the affair was concluded, and then I took the rabbit for my share, and allowed the weasel to go in search of another supper when and where it might think fit."

In many parts of the country it is only necessary to sit down quietly by the roadside in the neighbourhood of a plantation, and remain there motionless for a time, to be rewarded by a sight of the rapid, but stealthy, movements of the Weasel.

The Marten is another of the same tribe, of which there are two kinds, the one with a white throat and breast, called the Beech Marten, and one with a yellow throat and breast, called the Pine Marten. Some consider them distinct species.

The Beech Marten is the most common of the two in the South, inhabiting woods, and making its home in hollow trees. The Pine Marten is the most common in Scotland, where it frequents the fir woods, and builds its nest in the tops of trees. In their 
habits and mode of life Martens greatly resemble the Stoat and Weasel. Sir William Jardine says: "It sometimes takes up its abode in ruined buildings and hollow trees, and it can ascend a wall or a tree with as much agility as the wild cat; but its arboreal habits are much exaggerated by authors, and its chief exploits are performed on the ground. In the north of

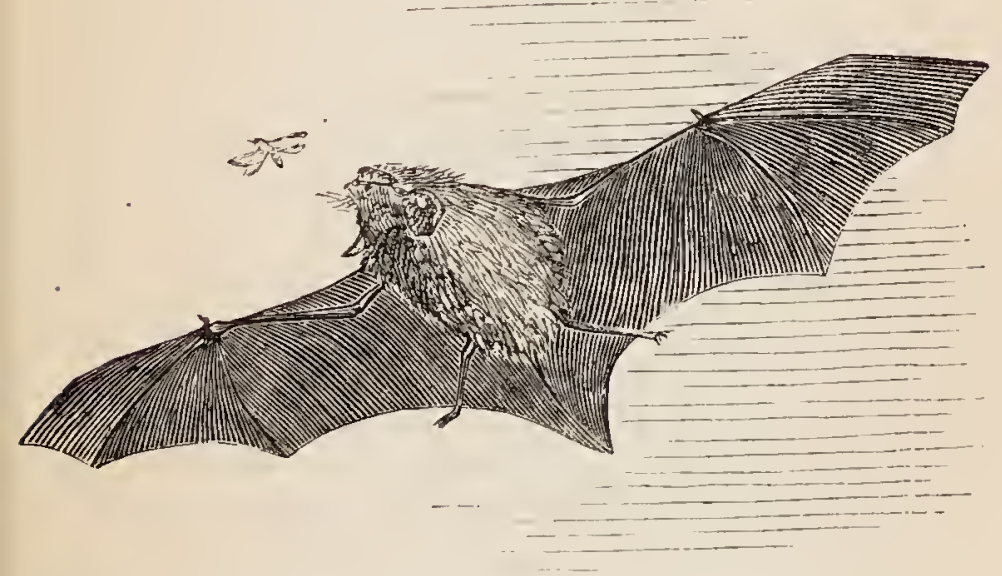

GREAT BAT.

Scotland, where it is named Taghan and Polecat, it has been known to destroy very young lambs, but scarcely ever ventures into the vicinity of human habitations at night, as it is said sometimes to do in England, where farmyards have been plundered by it. Whatever may be the case on the Continent, it cannot with truth be said that in Britain the Marten resides chiefly in trees, however admirably its structure may be supposed to be adapted to this mode of life." 
Only two kinds of bats are addicted to trees; these are the Noctule or Great Bat, and Natterer's Bat, but these are by no means confined to woods. Bats may often be seen flying about in woodlands in search of insects ; and so many other of our indigenous animals, not enumerated here, are occasionally to be met with in such situations,-shrews, rats, mice, rabbits, \&c.; but as they are not exclusively or chiefly sylvan species, it has not been considered necessary to notice them. No "hard-and-fast line" can be drawn, either with animals or plants, in many instances, because, in some conditions, and under some circumstances, they will be found in one locality, and at other times in another. There are animals, as well as plants, which have the faculty of accommodating themselves to varied conditions.

The total number of British quadrupeds is small, but after eliminating the aquatic species it will be observed that half of that number, and certainly those which possess the greatest interest, are sylvan in their habits. If the whole number be estimated at sixty species, there are not less than eighteen of these aquatic, and sixteen bats; so that there really remain only twenty-six to be accounted for, and of these onehalf are more or less sylvan in their habits, the residue including deer, hare, rabbit, rats, mice, shrews, otter, and arvicoles. 


\section{CHAPTER VIII.}

BIRDS.

OF all the inhabitants of the woods birds are the most universal favourites. The most poetical eulogy of them in prose is the volume entitled "The Bird," by Michelet ; the most enchanting histories, those of Wilson and Audubon. The former tells us that "Man could not have lived without the bird, which alone could save him from the insect and the reptile; but the bird had lived without man. Man or no. man, the eagle had reigned on his Alpine throne. The swallow would not the less have performed. her yearly migration. The frigate-bird, unseen by human eyes, had still hovered over the lonely ocean waters. Without waiting for human listeners, and with all the greater security, the nightingale had still chanted in the forest his sublime hymn. And for whom? For her whom he loves, for his offspring, for the woodlands, and, finally, for himself, his most fastidious auditor." Then again he writes forcibly of the services rendered to us by birds. "Many are the assiduous guardians of our herds. The heron gardebauf, making use of his bill as a lancet, cuts. the flesh of the ox to extract from it a parasitical worm which sucks the blood and life of the animal. 
The wagtails and the starlings render very similar services to our cattle. The swallows destroy myriads of winged insects which never rest, and which we see dancing in the sun's rays: gnats, midges, and flies. The goat-suckers and the martinets, twilight hunters, effect the disappearance of the cockchafers, the gnats, the moths, and a swarm of nibbling insects which work only by night. The magpie hunts after the insects which, concealed beneath the bark of trees, live upon its sap. The humming-bird, the flycatcher, in tropical countries purify the chalice of the flower. The bee-eater in all lands carries on a fierce hostility against the wasps which ruin our fruit. The goldfinch, partial to uncultivated soil and the seeds of the thistle, prevents the latter from spreading over the ground. Our garden birds-the chaffinches, blackcaps, blackbirds, tits-strip our fruit bushes and great trees of the grubs, caterpillars, and beetles, whose ravages would be incalculable. A large number of these insects remain during winter in the egg or the larva, waiting for spring to burst into life; but in this state they are diligently hunted up by the mavis, the wren, the troglodyte. The former turn over the leaves which strew the earth; the latter climb to the loftiest branches, or clear out the trunk. In wet meadows you may see the crows and storks boring the ground to seize on the white worm which for three years, before metamorphosing into a cockchafer, gnaws at the roots of grasses. Here we pause, not to weary our reader, and yet the list of useful birds is scarcely glanced at." 
We are thus introduced to the company of the feathered race, the liveliest and most ubiquitous of woodland denizens. Some of them come there only to breed, spending most of their time, when not so occupied, in the "open." This is the case with the

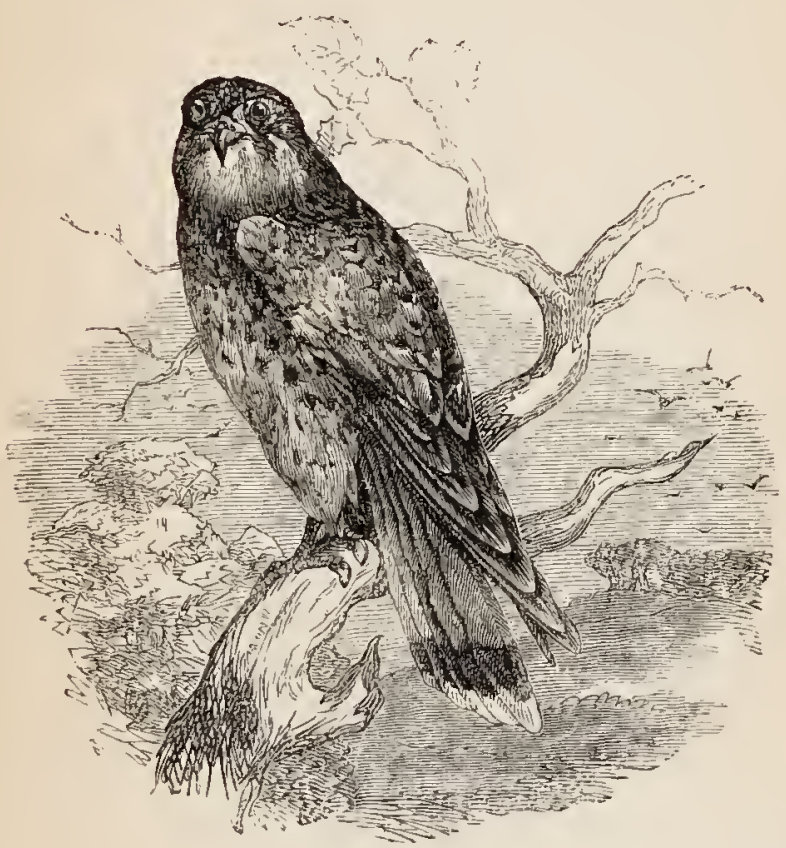

TIE KESTREL,

larger birds of prey, of which two only can claim to have their home in such places. One of these is the Kestrel, and the other the Sparrow-hawk. The Kestrell is sometimes called the Windhover, from the manner in which it hovers in the air when in search

1 Falco tinnunculis. 
of prey, which consists of smaller birds and small animals. Some deny that it attacks small birds at all, and that the whole of its prey consists of mice and shrews, and on the faith of this they contend that it is a very useful bird and should not be destroyed by gamekeepers, as often is the case. Unfortunately, the remains of birds have frequently been found in its stomach, and hence it cannot be acquitted. Kestrels breed in rocks as well as trees, so that even in the breeding season they are not wholly sylvan in their habits.

The Sparrow-hawk ${ }^{l}$ is one of the boldest of its tribe and the terror of small birds, which fly off, screaming, at its approach. "It comes," writes one, "silently and swiftly gliding, at the height of a few feet, over the grass field, now shooting along the hedge, now gliding over it to scan the other side, and again advancing with easy strokes of its halfexpanded wings. As if suspecting the concealment of something among the grass it now hovers awhile, balancing itself with rapid but gentle beats of its wings, and a vibratory motion of its expanded tail; but unable to discover any desirable object, away it speeds, bounds over the stone wall, and curving upwards alights on that stunted and solitary ash, and surveys the neighbourhood. From such a station it will sometimes dart suddenly on some unsuspecting bird not far off, but more frequently it proceeds to a distance before it finds its prey. So rapid is the descent of this plunderer that, to one who has unexpectedly witnessed it, nothing can be much more

1 Falco nisus. 
surprising. I have seen a sparrow-hawk rush headlong into the midst of a dense thicket, and suddenly emerge on the other side, carrying off a thrush in its talons." As an evidence of its audacity, Macgillivray says that while some sparrows were quietly enjoying the pickings of some horse-dung on one of the streets in Edinburgh, on which many persons, including himself, were passing, a sparrow-hawk glancing among them carried one off in a moment.

The predacious birds which hunt during the night are also represented by ordinary woodland species-the Long-horned Owl and the Tawny Owl. The silent flight of these birds is very peculiar, and is described by Shakespeare as the "night owl's lazy flight." The Long-eared $\mathrm{Owl}^{1}$ is common in fir woods in the North. If one of these birds appears in the face of day, the small birds surround him. "They buffet him, peck at and menace him on every side; while the owl turns his eyes from party to party, evading their blows as well as he can. The uproar is now great; each bird, in its mother tongue, venting execration on the poor owl. On such occasions one may get within a few. feet of it. At length he takes wing, generally flies a short distance, often pursued by a chaffinch or two." In Norfolk this "mobbing of the owl" by small birds is a circumstance well known to the country-folk.

The Tawny Owl 2 hides during the day in dense woods, coming out at dusk to feed on rats, mice, birds, and insects. This bird, as well as some other

- Otus vulgaris.

2 Syrnium aluco.

L 
owls, has been credited with a fishing propensity. Waterton was watching one of them carrying mice to its nest, when suddenly she dropped perpendicularly into the water. Thinking she had fallen down in an epilepsy, his first thought was to go and fetch the boat; but before he had got to the end of the bridge on which he was standing, he saw the owl rise out of the water with a fish in her claws, and take it to the nest.

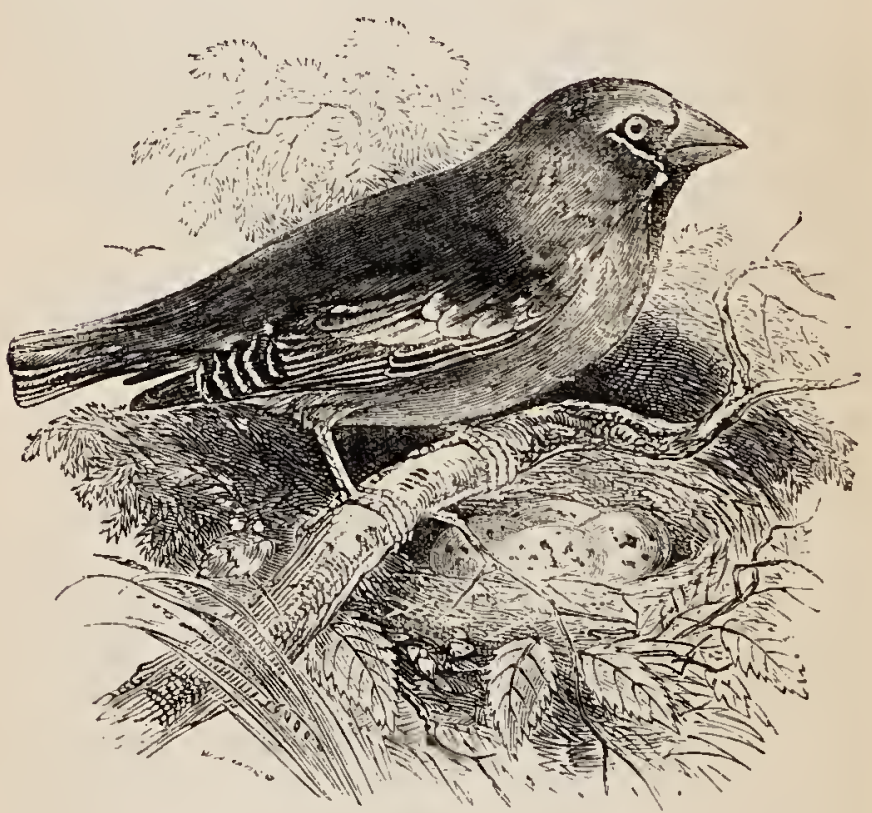

THE RED-BACKED SHRIKE.

A much smaller predatory bird than any of these is the Red-backed Shrike, ${ }^{1}$ a summer visitant found at 
the outskirts of woods and in hedges. It is sometimes called the Butcher-bird, from its habit of impaling its prey upon thorns in the vicinity of its nest. Mr. Hewitson says, "Seeing a Red-backed Shrike busy in a hedge, I found, upon approaching it, a small bird, upon which it had been operating, firmly fixed upon a blunt thorn; its head was torn off, and its body entirely plucked." This is a sufficient answer to those who assert that this bird does not "spike" its prey.

We might class together all our birds under three groups,-our permanent residents, another of summer visitors, and a third of winter visitors; or we might associate together the birds of prey and the insectivorous birds, and the granivorous birds; but for all the purposes of this work no elaborate system is essential, and they may be named in the usual order in which they are commonly classed.

The Blackbird and Thrush, although plentiful enough and well known, are not exclusively wood birds ; but this cannot be said of another :-

" 'Tis the merry Nightingale

That crowds, and hurries, and precipitates, With fast thick warble his delicious notes, As he were fearful that an April night Would be too short for him to utter forth His love chant, and disburthen his full soul Of all its music."

This "syren of the woods" is one of our visitors, and a welcome one, too, for its song is unsurpassed. Many a writer has pronounced eulogies on the music 
of the Nightingale, ${ }^{1}$ but none more flattering than that of old Izaak Walton. "He that at midnight, when the very labourer sleeps securely, should hear, as I have very often, the clear airs, the sweet descants, the natural rising and falling, the doubling and redoubling of her voice, might well be lifted above earth, and say, Lord, what music hast Thou provided for the saints in Heaven, when Thou affordest bad men such music on earth." It seems to be a refinement of cruelty to shut up such a songster in a cage, and a just revenge that the song obtained under such conditions is inferior to that chanted freely amongst the trees. Catching nightingales is a profitable employment around large towns. Mr. Harting tells of one adept at bird-catching near London, who at one time rented a cottage at $£$ io a year. "If there was what he called a good nightingale season, he made more than enough to pay his rent by the capture and sale of these birds! In one season alone he caught fifteen dozen, receiving eighteen shillings a dozen for them in London. He told me also that on one occasion he caught no less than nineteen nightingales before breakfast in the grounds of one gentleman, and in sight of the windows; for which, as I told him, he ought to have been transported."

The Blackcap ${ }^{2}$ is considered by some as a warbler second only to the Nightingale. It also is a summer visitor, and of very modest plumage. In song it is almost a "mocking bird," for it will seem to copy the notes of the Nightingale and other birds that it chances 
to hear sing. Sometimes it resembles the Thrush, then the Robin, and at another time the Lark; and yet those who study the language of birds declare it to be 110 imitator, but that its own natural melody combines the beauties of all into one harmonious strain.

The Garden Warbler, ${ }^{1}$ or Pettychaps, leads a quiet, retired life while it stays with us in the summer amongst thick brambles, and the undergrowth in woods and plantations, whence it rambles into the gardens which may be in the neighbourhood. It never seems to be so common as the Blackcap, but is widely dispersed.

Two of the commonest of ourwarblers are the Whitethroat, ${ }^{2}$ and the Lesser White-throat. ${ }^{3}$ The former is the most common of the two. Both are probably greater lovers of quiet lanes and hedgerows than woods. Their lively habits render them amusing objects. "If you happen to approach its nest, it comes up scolding vehemently, with a churring sort of voice, and flits about until you leave the place, attempting by short flights to induce you to pursue it, when it flies along the hedge before you. Its song is often heard very late at night, and is amongst the earliest that come on the ear in the fine summer mornings. If you be walking along a hedge in the early twilight, the little creature is sure to come up, announcing its presence by its song, and flitting in advance for, perhaps, a long way." Like most warblers, they are orily summer visitors.

There are only three other warblers to which it is

1 Sylvia hortensis.

${ }^{3}$ Sylvia curruca.

${ }^{2}$ Sylvia cinerea. 
necessary to allude here. These are the Wood Wren, ${ }^{1}$ the Willow Wren, ${ }^{2}$ and the Chiff-chaff. ${ }^{3}$ The last is the least commonly seen in woods of the three. The chief food of all of them consists of insects, of which they destroy a large number, and yet short-sighted man makes war upon all small birds, whilst they are his greatest friends. The Wood Wren, or Wood Warbler, has a "shrill, shaking sort of note, which may be heard at a great distance, and cannot be confounded with the song of any other bird." The song of the Willow Wren is very soft and pleasing, consisting of several plaintive notes in a descending scale. The latter becomes very tame in confinement, and one author states that a bird of this species became so familiar that it would take flies out of his hand.

Every one knows the Tits, all the family of the Tits-the Great Tit, the Blue Tit, the Long-tailed Tit, the Cole Tit, the Marsh Tits, and all the little Tits. They are the very mountebank of birds, head upwards, head downwards, creeping over the branches, now on one side, now on the other, twittering, and bobbing around on all sides, ever restless in their search for insects; now and then pecking away at the young buds, though not with mischievous intent, but because they know that an insect is concealed within. It is not the buds they eat, but the maggots which they contain. Immense numbers of oak-galls are robbed of their insects every year by these lively little Tits, and yet they are persecuted, whilst they should be

1 Sylvia sylvicola.

2 Sylvia trochulus.

3 Sylvia hippolais. 
assiduously protected. "If you happen to be sulky or moody, look on; you cannot fail to be cheered and soothed by the sight, so lively, merry, and frisky a creature must needs divert you. Tom-tit is no actor, but an original, and a very clever one withal."

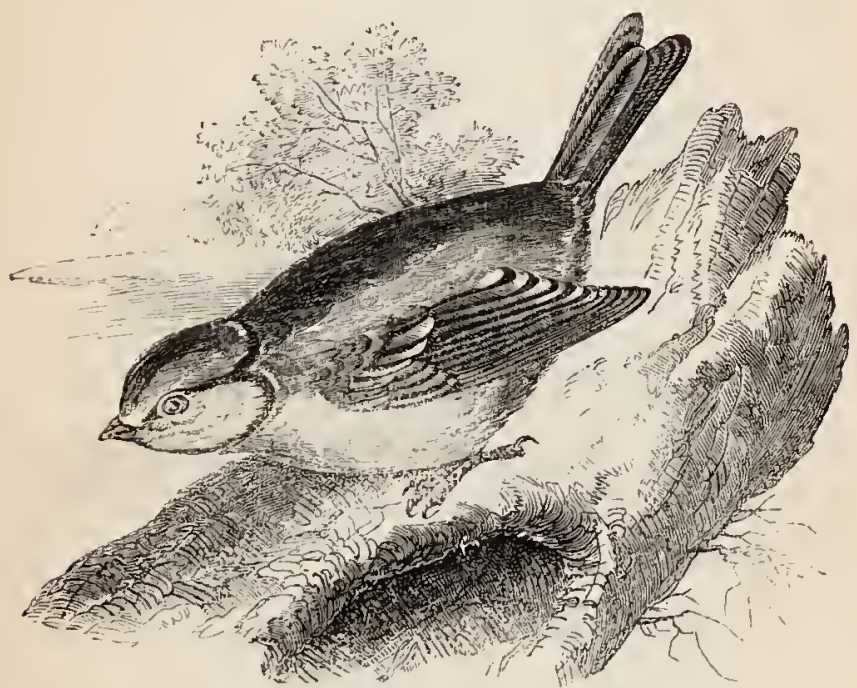

THE BLUE TITMOUSE.

The Pipits are something like larks in appearance. and yet not larks. There is one of them which falls in our circuit, and that is the Tree Pipit, ${ }^{1}$ which makes its appearance here in May, and goes at once to the woods. Perched on the tops of the highest trees, they twitter, but during descent to the ground they perform their song. "Few lovers of Nature can have failed to observe this small brown bird, perched on

1 Anthus arboreus. 
the topmost twig of an oak. Rising ten or twelve feet into the air with joyous song, it hovers for a few seconds over the tree, singing the while, and then, with wings expanded, and almost meeting over its back, and legs hanging straight, it drops perpendicularly upon the twig from whence it arose."

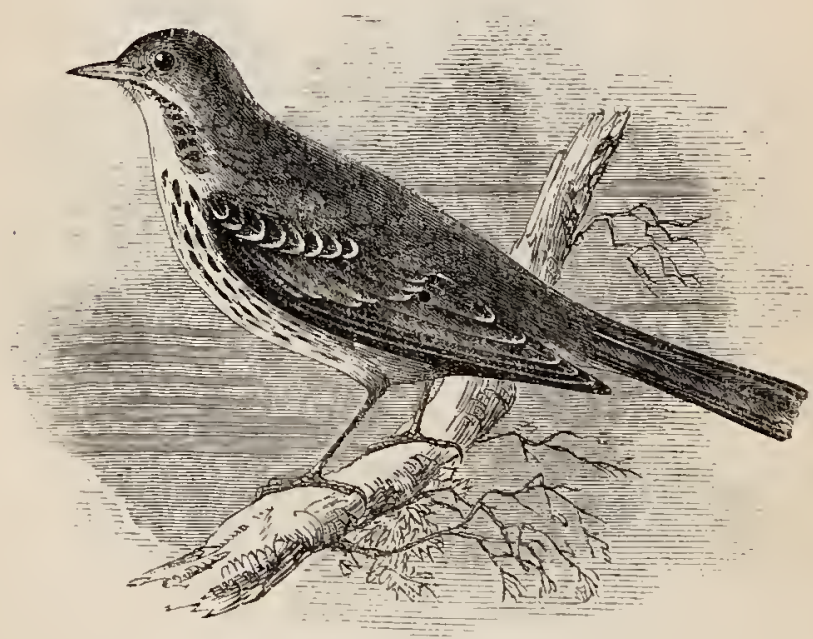

THE TREE HHIT.

Larks do not add much to the music of the woods, for the Wood Lark is scarcely common anywhere, and is seldom in the woods. The Buntings deserve a like report, for even the common Yellow-hammer must be sought in the green lanes.

Finches are numerous, both in species and individuals. Leaving the saucy Chaffinch to enjoy himself in gardens, and the House-sparrow to his predilection 
for human habitations, we have still others which hang: about the borders of woods. The Brambling is fond of beech mast, and hence may be seen in autumn and winter near beech-trees, but, being only a winter visitor, he will be sought in vain during the summer months. The Greenfinch, Linnet, Twite, and Goldfinch more or less congregate in companies, and frequent the waste places, where thistles, dandelions, groundsel, and other herbaceous plants fumish their

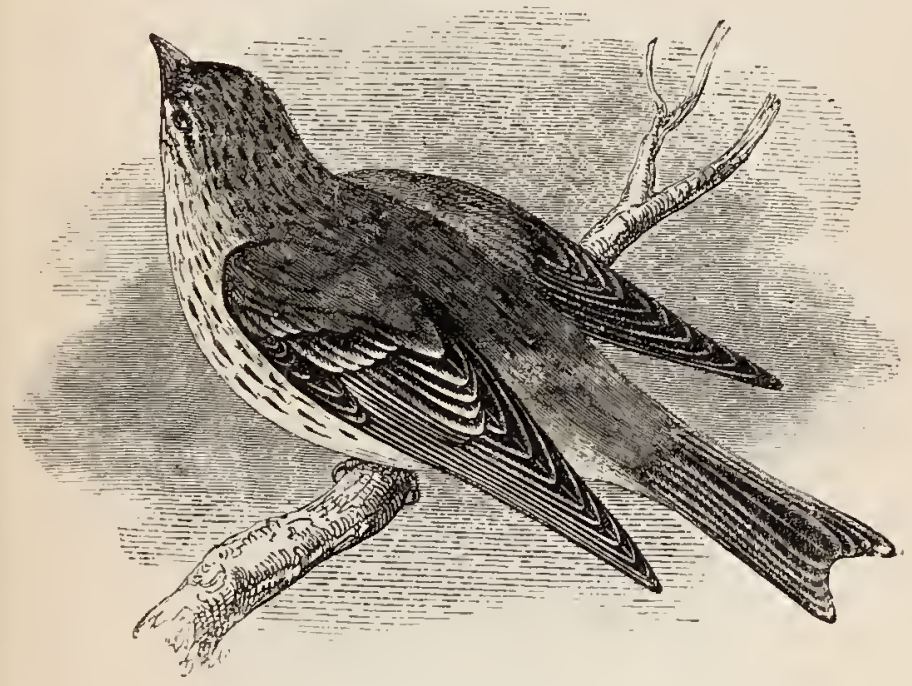

TIIE SISKIN.

favourite food. The Siskin and the Redpole are also sociable birds, but they have a tendency to hang about the margins of woods, and some individuals will be found penetrating into the interior. The Bullfinch, on the other hand, seems most at home in the woods, whence he strays now and then in search of seeds, 
or, perhaps, a flight into some neighbouring garden. One of the most singular and noticeable of the Finches is the Hawfinch. I It is not usually considered a common bird, and in some localities is certainly rare. Many of the Finches-almost all of them-are to be seen in the London bird-shops, but it is seldom that the Hawfinch is in their company. In Epping Forest this bird is to be seen throughout the year, feeding on

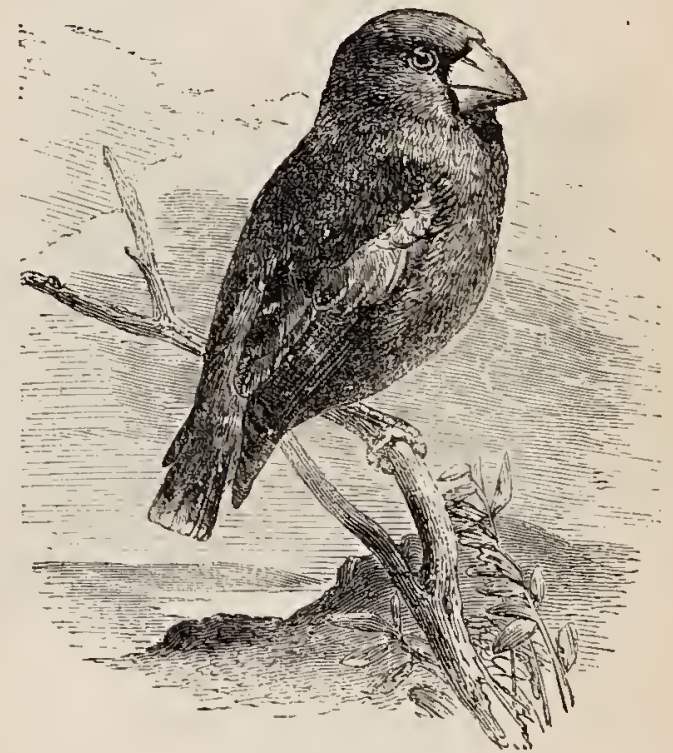

THE HAWFINCH.

the seeds of the hornbeam and other berries, and may be considered common. It is a poor songster, but a good nutcracker, for which its large, hard, powerful beak is admirably adapted.

' Fringilla coccothraustes. 
The Crossbills are such uncommon birds in the South, generally confining themselves to fir woods, and feeding on the seeds of the Scotch fir, larch, and other pines, that many persons well conversant with all our feathered friends have never seen one at large. They are sometimes met with in captivity, and are very amusing captives. Flocks of them in exceptional years make their appearance in the eastern and midland counties, and one fortunate observer says, "I have seen them, hundreds of times, when on the larch, cut the cone from the branch with their beak, and, holding it firmly in both claws, as a hawk would a bird, extract the seeds with the most surprising dexterity and quickness." These birds are called "Crossbills," because, when their beaks are closed, the curved extremities cross each other.

Although crows and rooks nest in high trees, they are much more birds of fields and open places; but the Magpie and Jay, especially the latter, are true wood birds. The mischievous propensities of the Magpie are proverbial, and belong to the whole of the Crow family. This, above all the rest, is convicted of egg-stealing, and hence a war of extermination is waged against it by gamekeepers, which reduces its numbers, so that now it is nowhere truly common. The Jay is a handsome, but a very noisy, unmusical screecher, and of a quarrelsome nature. One is almost certain to hear, if not to see jays, in most woods, for they get up a squabble amongst themselves incessantly, and in consequence are often shot for their trouble. Montague says that a jay "will at intervals imitate the bleating of a lamb, 
the mewing of a cat, the note of a kite or buzzard, hooting of an owl, and even the neighing of a horse. These imitations are so exact, even in a natural wild state, that we have frequently been deceived." Truly a happy combination, more melancholy than musical, the like of which we never heard, and certainly cherish no great desire to add to our experiences.

The Woodpecker, "tapping at the old oak-tree," is a bird of the South of Britain, but certainly prefers tapping at the elm to the oak. The Green Woodpecker is more common generally than the Spotted Woodpecker, and may occasionally be seen climbing up the old trunk of some tree, or resting midway and tapping the bark, catching up stray insects with its. long tongue. It is very fond of ants, and will perch itself on a hillock, and feast at leisure upon its inhabitants, never scratching, but turning over the soil with its strong bill.

There is some similarity between the habits of the Woodpeckers and the Wryneck. ${ }^{1}$ The latter is a smaller bird, with plumage of sober brown, with the same habit of climbing trees or walls in search of insects, and building its nest in the hole of a tree. When disturbed in its nest, it utters a hissing sound, which some compare to that of a turkey-cock, and others to that of a serpent. For this reason it has obtained the names of Snake-bird and Turkey-bird. "Cuckoo's mate" is another name which it has acquired, on account of arriving in this country about the same time as the Cuckoo. The Wryneck is 
remarkable for a habit of twisting the neck with a slow undulatory movement, like that of a snake, turning its head back and closing its eyes. In I 865 a pair of these birds built their nest in a hole in an apple-tree in an orchard near Burnham. The female was caught one day while sitting on her eggs and carried to Eton, where it was sold to a gentleman who set it at liberty. Its captor observed the bird on the apple-tree the next morning, and as he had marked it there could have been no mistake. Instinct had enabled this bird to find its way back again, after having been carried in the boy's pocket a distance of seven miles.

The little "Creeper" I is a still smaller bird, of rather livelier habits, often seen clinging to the rough bark of an old elm, and advancing by short jerks. As it climbs it searches every crevice, proceeding upwards, now on one side, and now on the other. At length it reaches the branches and moves along them, sometimes on the top, but as often beneath, hanging on meanwhile with its back tuwards the ground. Thus like a mouse it creeps over the tree, uttering at times a shrill and feeble cry, and then flies off to another, commencing again at the base.

The "Nuthatch" 2 is a rarer and more local bird, although it remains throughout the year. It has the same habit of creeping up the bark of trees, but differs in one respect from the other climbers in the readiness with which it passes downwards head foremost. Its food is not by any means confined to insects, but is varied with nuts and seeds. One writer says, 
"Its dexterity in opening nuts and the stones of fruits is curious; it fixes the nut in a crack on the top of a post, or on the bark of a tree, and placing itself above it, head downwards, strikes with great force and rapidity with its strong wedge-shaped bill on the edge of the shell till it splits it open. When the food of these birds is plentiful, they have a favourite crack for unshelling the kernels, as sometimes a peck of broken shells may be seen under this crack."

" Cuckoo! Cuckoo! O ! welcome, welcome notes !

Fields, woods, and waves rejoice

In that recovered voice,

As on the wind its fluty music floats."

We all welcome the Cuckoo, because it assures us that spring has commenced; and the sound by which its presence is announced is so familiar, and so unlike any other, that the little child and the gray-haired veteran recognise it alike and give it welcome. If the note of the Cuckoo is observed, it will be found to commence with the interval of a minor third, and during the season proceed upwards until it reaches the interval of a fifth. It is said never to attain a minor sixth. "Have you heard the Cuckoo?" is a common inquiry in early spring. And this perhaps leads to other inquiries, for there are superstitions and omens associated even with the Cuckoo. It is considered an unlucky omen if you have no money in your pocket when you hear the Cuckoo for the first time in a season. Those who hear the Cuckoo first are supposed to be the most fortunate, and those who hear the notes repeated the greatest number of times on the first occasion in the year have the advantage. 
It was considered a reproach to one to have heard the Cuckoo while hungry. The one feature in this bird's character which is justly charged upon it as disreputable, is that instead of building a nest and rearing its young, the female lays her egg in the nest of some other bird, and leaves to strangers all the labour of hatching and bringing up its progeny.

The "Fern Owl," or "Goatsucker," flies in the dusk round the borders of woods through the summer, and catches insects in its flight. Heathy places, and open downs, wherever insects most do congregate, are attractive, but its method of hunting cannot be pursued in a dense wood. This bird is also called the "Night-jar," and the "Moth-hawk," so that it is well furnished with popular names. There is, unfortunately a prejudice against this bird amongst gamekeepers, but without any reason; it is difficult to discover how such a prejudice originated, as its food consists of insects, which it catches on the wing. The name of "Goatsucker" is derived from the supposition that it sucks the udders of cows and goats, but this is entirely a vulgar error, as any one may become convinced by a little patient observation.

The Ring-dove, or Wood-Pigeon, is found in all the wooded districts of England and Scotland, where it prefers the highest trees. "No bird in the British dominions," writes Waterton, "seems to resort to so many trees and shrubs for the purpose of incubation as the Ring-dove. Not a tree, from the towering pine to the lowly thorn, ever comes amiss to it. There is something too peculiarly singular in the locality of some of the nests. While one is seen 
placed nearly on the topmost branches of the lofty sycamore, another may be found within four feet of the ground, in the humble shelter of the hedgerow bush." And again, "Ring-doves are exceedingly numerous here during summer; and when winter sets in many thousands come every evening to take up their quarters for the night. They retire early to roost, and never leave the trees till all the other birds are on the stir." There seems to be a mournfulness in the monotonous "Coo-Coo" of the Ring-dove when heard in the depths of a forest, a kind of fretful complaint of which the notes of songsters do not partake.

We are closing our gossip on the feathered tribes without scarcely a mention of those charming productions of their instinct and perseverance, "birds' nests." We have done so advisedly, so as not to stimulate the curiosity of our younger readers into a desire for birdsnesting, or give them an excuse for its pursuit. We have had interesting books written on "Bird Architecture," on "Homes without Hands," and kindred topics, which have almost exhausted the subject; whilst at the same time they have exhibited such marvellous examples of ingenuity, of instinct bordering on intelligence, that we are fain to believe would inspire their readers with such respect for the little architects as to leave their homes in peace.

There is as much of character in the nest and the eggs as in the birds themselves. It is not difficult to determine the bird from its nest, much less from its eggs. In some instances there is evidence of a refined architectural taste, if such a term may be applied; 
in others there is less care, less elaboration, less neatness, even amounting to slovenliness and carelessness. And the eggs too differ, not only in size, but also in colour and in ornamentation. The eggs of such birds as the Kestrel, and especially of the Guillemot (a water-bird), vary so much in their markings that two can rarely be found absolutely alike, and yet the general colour and the character of the markings are so decided that there is never any difficulty in determining the bird to which they belong. In our juvenile days we remember that schoolboys in the country were always ambitious to outnumber each other in the birds' eggs collected during a season. For this purpose the shells were threaded upon a string as they were plundered, and in many cottages a long trophy of birds' egg-shells hung suspended from the ceiling. This barbarous practice is now checked, and it is hoped that farmers and gardeners are beginning to learn that small birds are their greatest friends. 


\section{CHAPTER IX.}

\section{BEETLES.}

InSECTS abound wherever vegetable life is profuse. The green plant or the decaying plant furnishes food to myriads of minute insects; larger carnivorous insects find here the favourable conditions which their habits demand; hence they collect in such spots, and prey upon the smaller and weaker. Birds and reptiles follow the insects; quadrupeds in their turn follow the birds. The flesh-feeders thus depending one upon another for existence, have a primary dependence upon vegetable life. There are, of course, exceptions to this, in the case of the quadrupeds and birds which are direct vegetable-feeders. In all cases the original source of support to animal life lies in the vegetable; hence, wherever there is the greatest variety of plants there will naturally be the greatest variety of animals, whether quadrupeds, birds, reptiles, or insects. ${ }^{1}$

1 "Facts serve to show," writes C.V. Riley, "that, seek where we may, we cannot find a place or a substance in which or on which some insect does not feed. They people the atmosphere around us, swim at ease in the water, and penetrate the solid earth beneath our feet, while some of them inhabit indifferently all three of these elements at different epochs of their lives." 
Insects, unlike the higher animals, have three stages of existence-the caterpillar stage, the pupa or chrysalis stage, and the imago, or perfect insect. Through these stages they all pass, whether beetles, bugs, butterflies, moths, bees, flies, \&c. From each of the preliminary stages the entomologist can determine the ultimate order to which the mature insect will belong. The immense number of insects which spring into existence during every month of the year whereever there is vegetation, would startle those who have had no experience amongst them. "From such considerations," writes Schrank, "are we not alarmed for our forests, gardens, and groves? Do not these innumerable millions of insects which incessantly labour at their destruction confuse our understanding when we begin to reckon them, and terrify our imagination which magnifies them? And can I be believed if I assert that I discover beneficence in such unspeakable destruction, beauty in these devastations, wisdom in this disorder, and life in this manifold death ? Nevertheless it is so. Whatever many may say of nature growing old, the naturalist finds her always young and beautiful, always estimable, just as she came from the hand of her Creator, and as she, indeed, every moment issues afresh from the hand of the Almighty Being. In His hand the youth of nature is continually renewed, and under His all-ruling providence all the millions of apparently destructive beings only labour in preserving her existence and embellishment."

Insects are classed by those who study them in several groups or orders, each of which has some feature which is peculiar to all the genera and species 
which the order contains. Beetles have two membranous wings, which are folded up and concealed during repose beneath a pair of hard, homy, or leathery wing-cases. Butterflies and moths have four wings, covered with minute scales. Bees, wasps, \&c., have four clear, transparent wings, and flies (as they are usually termed), or Diptera, have two transparent wings. Thus through all the orders a general feature prevails, by means of which the insects of one order may be distinguished from those of another. Beetles are the first insects to which our attention must be directed, and they may best be illustrated by one of the most common and best known of our indigenous species.

The habits and transformations of the common Cockchafer have been carefully observed, and will serve to exemplify those of the other insects of this family, which, as far as they are known, seem to be nearly the same. This insect devours the leaves of trees and shrubs. Its duration in the perfect state is very short, each individual living only about a week, and the species entirely disappearing in the course of a month. After the sexes have paired, the males perish, and the females enter the earth to the depth of six inches or more, making their way by means of the strong teeth which arm the forelegs: here they deposit their eggs, amounting, according to some writers, to nearly one hundred, or, as others assert, to two hundred, from each female, which are abandoned by the parent, who generally ascends again to the surface, and perishes in a short time.

From the eggs are hatched, in the space of fourteen 
days, little whitish grubs, each provided with six legs near the head, and a mouth furnished with strong jaws. When in a state of rest, these grubs usually curl themselves in the shape of a crescent. They subsist on the tender roots of various plants, committing ravages among these vegetable substances on some occasions of the most deplorable kind, so as totally to disappoint the best-founded hopes of the husbandman. During the summer they live under the thin coat of vegetable mould near the surface, but as winter approaches they descend below the reach of frost, and remain torpid until the succeeding spring, at which time they change their skins, and reascend to the surface for food. At the close of their third summer (or as some say of their fourth or fifth), they cease eating, and penetrate about two feet deep into the earth; there each grub by its motions from side to side forms an oval cavity, which is lined by some glutinous substance thrown from its mouth. In this cavity it is changed to a pupa by casting off its skin. In this state the legs, antennæ, and wing-cases of the future beetle are visible through the transparent skin which envelops them, but appear of a yellowish-white colour, and thus the pupa remains till February, when the thin film which encloses the body is rent, and three months afterwards the perfected beetle digs its way to the surface, from which it finally emerges during the night. According to Kirby and Spence, the grubs of the cockchafer sometimes destroy whole acres of grass by feeding on its roots. They undermine the richest meadows, and so loosen the turf that it will roll up as if cut by a turfing-spade. They do 
not confine themselves to grass, but eat the roots of wheat, of other grains, and also those of young trees. About seventy years ago a farmer near Norwich suffered much by them, and, with his man, gathered eighty bushels of the beetles. In the year I 785 many provinces in France were so ravaged by them, that a premium was offered by Government for the best mode of destroying them. The Society of Arts in London during many years held forth a premium for the bes: account of this insect, and the means of checking its ravages, but without having produced one successful claimar.t. ${ }^{1}$

The largest beetle we possess is called the "StagBeetle," 2 because its large mandibles, projecting in front of the head, resemble the horns of a stag. If any one should find it crawling over the ground in a wood, he may test the strength and importance of these mandibles or horns, and discover that they have a considerable nipping power. Professor Bradley has given a remarkable instance of the strength of one of these creatures. He asserts that he saw the beetle carry a wand a foot and a half long, and half an inch thick, and even fly with it, to the distance of several yards. Linnæus observes that if the elephant was as strong in proportion as the stag-beetle, it would be able to tear up rocks and level mountains.

Such an insect would have a caterpillar of corresponding size, and it is the belief of some authors that the famous "Cossus," a caterpillar which was fatted and eaten by the ancient Romans, was the larva of

"Harris's "Injurious Insects."

${ }^{2}$ Lucanus cervus. 
this beetle, whilst others contend that it was the caterpillar of the Goat-moth.

Dung-beetles, as the name suggests, inhabit dung, or are to be found in its neighbourhood. They are not mentioned so much on account of some of them being occasionally found in woods, as from their historical interest. These insects are possessed of considerable strength, as may be tested by placing them under a book, and watching their movements. Dr. Birchell was supping one evening in a planter's house of North Carolina, when two or three beetles were placed without his knowledge under the candlestick. A few blows were struck on the table, when, to his great surprise, the candlestick began to move about, apparently without any agency, except that of a spiritual nature, and his surprise was not lessened when, on taking one of them up, he discovered that it was only a beetle that moved.

These beetles have a habit of enclosing their eggs in round pellets of dung resembling pills, and this habit is associated with the legends and stories of the Egyptians and others, who held the Dung-beetle in esteem, regarding it as sacred.

The Scarabæus was considered among the Hindoos as a symbol of the Creator. This association passed from them to the Egyptians, and the sacred beetle is figured extensively upon their monuments. From Egypt the legend of the sacred beetle passed into Scandinavia. Plutarch says that the Scarabæus was adopted as an emblem of the sun, because these insects cast the seed of generation into round balls of dung, as a genial nidus, and roll them backward with their feet, 
while they themselves look directly forward; and as the sun appears to proceed in the heavens in a course contrary to the signs, thus the Scarabai turn their balls toward the west, while they themselves continue creeping towards the east ; by the first of these motions exhibiting the diurnal, and by the second the annual motion of the earth and the planets.

As to the beetle-worship of Egypt, Pliny writes :"The greater part of Egypthonourall beetles, and adore them as gods, or, at least, having some divine power

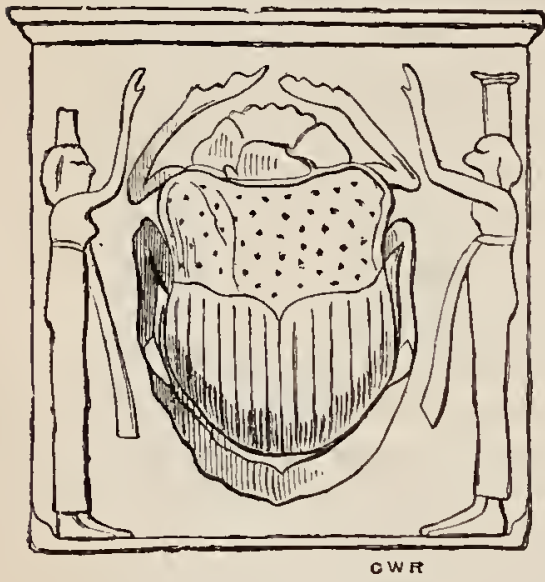

THE SCARAB EUS. in them." Not only were they venerated during life, but embalmed after death, in which state they are found at Thebes. A colossal Egyptian beetle in stone may be seen in the lower room of antiquities in the British $\mathrm{Mu}$ seum. Small images of the Scarabæus in baked earth, or other material, are found in great number with the mummies of Egypt. Placed over the stomach, it was deemed a talisman to shield the soul of its wearer against the evil spirits. Watching the Dung-beetle pursuing the same instinct which has guided its progenitors for thousands of years, we shall scarce fail to be reminded of its association with some of the oldest nations of the world. 
Whatever may have originated the stories of "Willo'-the-IWisp " luring travellers to destruction, it is certain that the glowworm has a real existence, and in most instances is the luminous female of a kind of beetle." "If you take one of these glowworms home with you for examination," writes Kirby, "you will find that in shape it somewhat resembles a caterpillar, only that it is much more depressed; and you will observe that the light proceeds from a pale-coloured patch that terminates the underside of the abdomen. It is not, however, the larva of an insect, but the perfect female of a winged beetle, from which it is altogether so different that nothing but actual observation could have inferred the fact of their being the sexes of the same insect."

The "little light" of our own glowworms is poor in comparison with that emitted by the fire-flies of the tropics :-

"One while they stream'd

A bright blue radiance upon flowers that closed

Their gorgeous colours from the eye of day ;

Now motionless and dark, eluded search,

Self-shrouded; and, anon, starring the sky,

Rose like a shower of fire."

Yet most of these fire-flies are beetles; and travellers tell not only of reading by their light, but of using them as candles in lighting the house, as torches to guide them when travelling by night, and, on festivals, of their being tied all over the garments of young people, who gallop through the streets on horses similarly ornamented, producing on a dark evening

1 Lampyris noctiluca, and other species. 
the effect of a large moving body of light. The Chinese lantern-fly is not a beetle; and even centipedes have the power of emitting light, as we have proved by experience.

The State Entomologist in a country speaking our own language, but in which the State encourages the pursuit of economic science much more than in our own, summarizes in a very compact manner the general features of the Snout Beetles, or Weevils, of which he remarks that there are not less than ten thousand good and distinct species known to be dispersed over the globe. He says they are at once distinguished from all other families by the front of the head being produced into a more or less elongated snout or rostrum, at the extremity of which the mouth is situated. The larvæ are whitish or yellowish fleshy grubs. Now there is hardly one of the one hundred families of insects from which so many injurious species can be enumerated, for, with the exception of one species, whose larva was found to destroy barklice, they are all vegetarians, the larvæ inhabiting either the roots, stems, leaves, or fruits of plants; and the beetles feeding on the same. So whenever you find an insect with the character just given, you may rest morally certain that it is injurious, and should be destroyed without mercy. This family is not only one of the most injurious, but, on account of the secretive habits of the larva, the insects comprising it are the most difficult to control. When a worm is openly and above-board denuding our trees, we at least readily become aware of the fact, and can, if we choose, apply the remedy; but when it surreptitiously, 
and always under cover, gnaws away at the heart of our grains and fruits, we become in a measure helpless to defend ourselves. But even here, where the enemy is so well ambushed and hidden, the proper tactics, based on thorough knowledge, will frequently enable us to penetrate the defences, and conquer the foe.

Some of these beetles are so minute as scarcely to exceed a good-sized flea. It is difficult to 'enumerate all the varied haunts to which these destroyers find their way. Suffice it to say that they are plentiful in woods, as well as gardens, granaries, and even houses. The habits of one of them are unfortunately those of a great number. This Weevil, 1 which attacks the Lime, Birch, Mountain Ash, and other trees, makes its ascent during the night and feeds on the foliage and bark both of young and old shoots, and during the day lodges at the foot of the tree, slightly concealed in the earth, from its great resemblance to which it is difficult to detect. They commence their depredations about the middle or the latter end of April, and continue them for several weeks.

The Pine Weevil ${ }^{2}$ is but too common in fir plantations, especially in the North, and is large for the family. They attack both the bark and buds, and not only the bark of the branches and twigs, but also the roots near the surface of the ground, wherein the female is believed to deposit her eggs. This beetle is more injurious in its perfect state than in the larva. Young slender trees are often so much gnawed, as to be easily broken by the wind. When a bud is once 
pierced, it unfolds with difficulty or remains stunted. So wily is this weevil, that as soon as it hears a footstep it withdraws to a secure situation, and when there is the smallest movement of the bushes, the

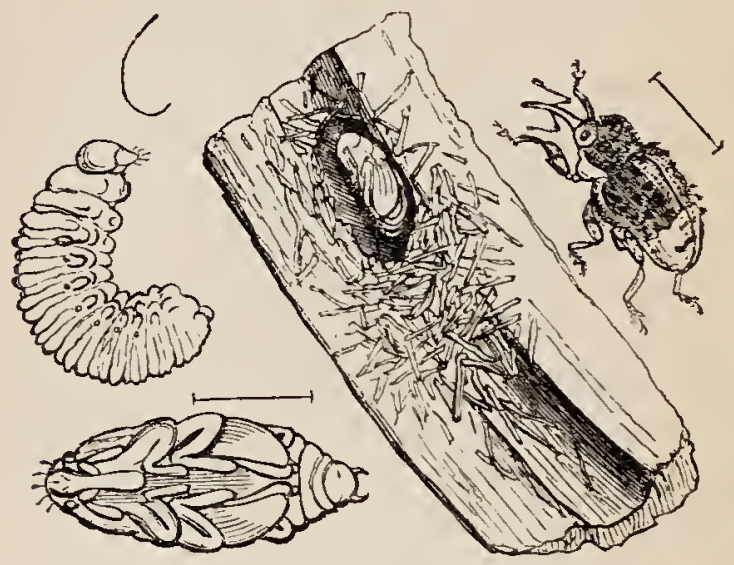

THE WILLOW BORING BEETLE.

whole brood fall into the grass below, so as not to be seen, and only a few stragglers can with difficulty be discovered on the ground.

Professor Westwood has given full particulars of one of these beetles which is very destructive to willows, although for a long time these injuries were attributed to another insect, which being attracted to the spot by the extravasated sap and rotten sawdust made by the larve of the Weevil, came to be considered as the cause of the mischief. The whole of the trunk in which these larvæ were found emitted a strong smell, somewhat like beer in a state of fermentation. The little white grub is very similar to that of the Nut-Weevil (another species not uncommon in 
hazel-nuts), and it is said that when they first attack a tree they eat through the bark and into the centre of the tree, sometimes not going so far as the centre, and sometimes eating for a considerable distance between the bark and the wood before entering the latter. They appear to attack the trees at or near the ground and eat their way from bottom to top of the main stem, occasionally eating through the outer bark. They begin their ascent by eating a round tubular hole several inches in length, occasionally winding off the first course at right angles. On looking amongst the trees so destroyed, at first sight they had every appearance of some one having wilfully taken a gimlet and bored holes for their own amusement. The perfect insect ${ }^{1}$ varies from one third to half an inch in length, of an opaque dirty-black colour, sprinkled with white scales, mixed with tufts of black ones. It feeds also on the alder. The beetle in its mature state may be found on the trunk or leaves of willowtrees during August and September. At an earlier period the grubs must be sought in their channels in the wood.

Allied to the Snout-beetles or Weevils, we may name a small beetle, ${ }^{2}$ with its body rather covered with hair, having a polished black thorax and brown wingcases, which may be seen in numbers running over the trunks of elms from the end of March to the first days of July, but principally about the end of May or commencement of June. It may then be seen entering into holes, with which the bark appears per-

1 Cryptorkynthus Lapathi.

2 Scolytus destructor. 
forated as though with a gimlet. It insinuates itself into these holes, or into the crevices of the bark, for the purpose of depositing its eggs. On stripping off a piece of the loose bark, we may easily understand how the barking of trees is effected by these minute animals, for the surface of the wood thus exposed presents to the view innumerable impressions, which

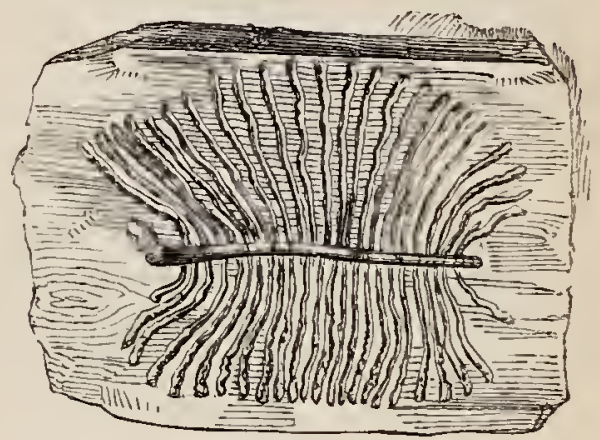

THE ELM-DESTROYING BEETLE.

may be compared to impressions or casts of large and broad Scolopendra. The middle or body of this singular impression marks the path of the perfect female insect while employed in laying her eggs, which is to her, as to most other winged insects, the immediate forerunner of death. From this tubular path, however, in which she deposits her eggs, the larva, which are hatched from these eggs in the shape of little white footless worms, proceed nearly at right angles, eating their way in parallel smaller tubes, which, lying close to each other, effectually serve to separate the bark from the tree. The larvæ remain feeding in the tree, generally between the bark and the 
wood, throughout the winter season. About the commencement of spring they assume the pupa state, and before the end of this season the bark of an infected tree begins to appear as if all its crevices were full of a very fine sawdust. The last change of the insect takes place, and being now winged, it tries to arrive at the external air for the purpose of propagating its species, and laying its eggs in other trees. Each hole, which now appears as if made with a gimlet, marks the exit of a perfect insect. In the first instance the voracity of the larvæ, and in the second, the endeavours of the perfect insects to liberate themselves from the wood, particularly when such attempts are made by almost infinite numbers, soon occasion the bark to fall in large pieces. The consequence is that the new leaves only make their appearance to wither, and the tree perishes. ${ }^{1}$

This is only one of several small beetles having nearly identical habits, similar in form and size, but with specific differences recognized by naturalists, living at the expense of growing trees. All over Europe they are recognized as the enemies of forest trees, and constantly efforts are being made to reduce the extent of their ravages. In $\mathrm{I}_{42}$ it was stated that there was scarcely a tree in the vicinity of Northwich which did not show symptoms of the decay in consequence of the depredations of the little "Ash Beetle." 2 This beetle pierces the bark, in the inner part of which it forms a horizontal passage, and at right angles to this passages on both sides of the

W. S. Macleay.

2 Iylceinus Fraxini. 
same the larva form other minute cavities nearly parallel to each other. The larvæ are small fleshy grubs with white bodies and chestnut heads.

In pine forests a similar little beetle is destructive in another wav. This beetlel burrows for one or several inches below the terminal bud on the youngest shoots of the Scotch fir, eating out the pith straight upwards, and gnawing out again near the bud or through it. It bores through the shoots of Spruce in like manner when there are none of the Scotch pine to be found. Its eggs are laid under the bark of sickly or felled pines. It would be useless to attempt to enumerate the minute beetles which revel in the vegetation of our woodlands, not only injuring the larger trees, but establishing themselves in the stems of herbaceous plants, taking possession of old fungi, and going down to the roots of grasses, in one or other of their stages.

Of all noteworthy beetles, none surpass in interest the prettylittle "Ladybirds," and fewinsects are more useful.

"I would not hurt it for the world;

Its prettiness says, Spare me ; and it bears

Armour so beautiful upon its back, I could not injure it to be a queen. 'Look, sir, its coat is scarlet dropp'd with jet, Its eyes pure ivory."

Throughout its whole career, this little insect is the determined foe of the Aphis, or Plant-louse, myriads of which it annually destroys. Immense swarms are sometimes seen in Kent and Sussex, where they feed 
on the hop-fly. In many places it is considered very unlucky to kill a ladybird. In Norfolk they are called Bishop Barnabee, and the children hold them in their open hands when caught, chanting meanwhile,-

" Bishop, Bishop Barnabee,

Tell me when my wedding be ;

If it be to-morrow day,

Take your wings and fly away;

Fly to the east, fly to the west,

Fly to him that I love best."

It cannot have escaped observation that the Ladybirds are a considerable family, some of which have the wing-cases scarlet, others yellow ; some are spotted with five, seven, or twenty-two black spots; others with ten, fourteen, or sixteen white spots ; and others, again, with white or black spots of some other number. These all vary a little in their habits and food, and, consequently, in the places where they should be sought. There is, nevertheless, a family likeness which will lead to their recognition, although ignorant persons have been known to capture them on suspicion of their being the terrible "Colorado Beetle."

The American enemy of the potato, which has had a bugbear season in this country, but not wholly without reason, belongs to a somewhat mischievous group. One, which might be called the "Willow Bug," except that it is a true beetle, ${ }^{1}$ is occasionally injurious to narrow-leaved fwillows. It is a pretty insect, of a shining blue or green colour, and of an

${ }^{1}$ Chrysonela vulgatissima. 
oblong-oval form, about one-sixth of an inch in length. It is found during winter months in great profusion under the loose bark of willows in damp localities. Its eggs are deposited on the young leaves, and, when hatched, the larvæ form little associations, feeding together in regular rows, the heads of the second row touching the tails of the first. In this manner they proceed from the base to the extremity of the leaf, which they soon strip of its parenchyma. Trey then attack the next leaf, and so on, until they are fullgrown, when they descend into the ground and assume the pupa state. After remaining a short time in this condition, they finally emerge in their full and perfect state. Some foreign species of this group are handsome bright-coloured little insects, which are strung as beads, or used in other ways for personal adornment by the ladies in the countries where they abound.

The Rove Beetles are very different from these last, and have long slender bodies, with very short wingcases, so that the tail portion of the body is exposed,an unusual circumstance with beetles. When a Rove Beetle is assaulted, or even at the approach of any one, this little creature's anger and courage are instantly manifested; he assumes a most formidable attitude, and is ready to defy even man himself: with his broad head erected and his terrific jaws widely expanded, his six legs spread out, and his tail curled up, he becomes at once an object of terror to the young and ignorant, and, indeed, to those who have unhappily neglected to make themselves acquainted with the habits of the insect world. How- 
ever; in the common affairs of life we must not be carried away altogether by outside appearances; and vicious as this little animal may be, despised or feared by all, and trampled upon by every one as an odious being not fit to live, it has, nevertheless, its virtues, which counterbalance its repulsive appearance. The larvæ of these beetles feed entirely upon animal matter, and therefore are not destructive to trees or plants ; and the mature insect is one of the deadliest enemies of the Earwig, which it attacks and at once kills with a nip from its formidable jaws, afterwards. sucking out the contents of its body. This insect is. not uncommon in gardens, and is known to children and gardeners as the "Devil's Coach-horse."1 Some of its representatives may be found in woods, and may, at first, even be mistaken for earwigs. At the least intimation of danger, up goes the tail portion, and by this, as well as the naked extremities, the "Staphs" may be known from others of the great commonwealth of beetles.

We might write of the Cetoniida, or Rose-chafers, of the Gold Beetles, of the family which includes the mysterious insects of which it is written:-

"And chambermaids christen this worm a Death-watch, Because, like a watch, it always cries click.

Then woe be to those in the house that are sick !"-

Of the Oil Beetles and Blister Flies, of Mealworms and Musk Beetles until we filled the volume with beetle lore, to the disadvantage of other insects. Nor is it necessary, for every one who desires to know

1 Staphylinus olens. 
more of these marvellous creatures, and this wonderful world, will discover for himself more than we could teach him. His experience will then be akin to that of the Rev. Charles Kingsley when he wrote, "I have so long enjoyed the wonders of nature; never, I can honestly say, alone, because when man was not with me I had companions in every bee, and flower, and pebble; and never idle, because I could not pass a swamp or a tuft of heather without finding in it a fairy tale of which I could but decipher here and there a line or two, and yet found them more interesting than all the books, save one, which were ever written upon earth." 


\section{CHAPTER X.}

\section{BUTTERFLIES AND MOTHS.}

THE most attractive of all insects are the Lepidoptera, especially those which from their habit of flying about during the day are called diurnal Lepidoptera or Butterflies. As other perfect insects, so these pass through three stages of existence,--caterpillar, chrysalis, and imago, or winged insect. The most beautiful, as well as pleasing, emblem among the Egyptians was exhibited under the character of Psyche-the soul. This was originally no other than a butterfly, but it afterwards was represented as a lovely female child with the beautiful wings of that insect. The butterfly, after its first and second stages as an egg and larva, lies for a season in a manner dead, and is enclosed in a sort of coffin. In this state it remains a shorter or longer period; but at last, bursting its bonds, it comes out with new life, and in the most beautiful attire. The Egyptians thought this a very proper picture of the soul of man, and of the immortality to which it aspired. But they made it more particularly an emblem of Osiris, who having been confined in an ark or coffin, and in a state of death, at last quitted his prison, and enjoyed a renewal of 
life. This symbol passed over to the Greeks and Romans, who also considered the butterfly as the symbol of Zephyr.

The day-flying butterflies are neither so large, so numerous, nor so brightly coloured in our northern climate as in the Tropics, yet we have two or three which, both for size and colouring, compare favourably with those of more sunny lands.

The first of all our British butterfles, entitled fully to its name, is the "Emperor"; and although it hovers over the tops of the highest oaks, and is considered a habitant of woods, he may consider himself

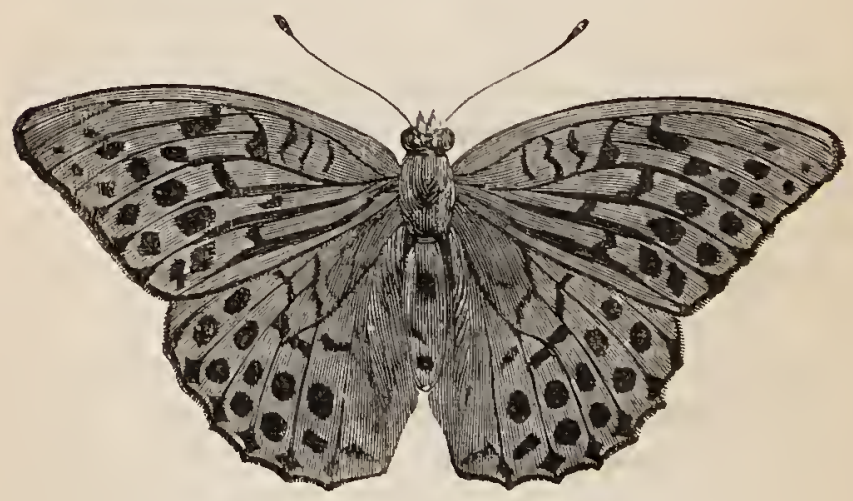

THE SILVER-WASIEED FRITILLARY.

fortunate who succeeds once during his life to capture a specimen for himself. Entomologists delight to recount their adventures in quest of this royal game, and some have achieved great success. It is a but- 
terfly of rather depraved tastes, as proved by the fact that swine's dung, dead stoats, and such unsavoury odours have proved the best means of luring them to their destruction.

The White Admiral, although a woodland species, is certainly local, and is confined to the southern portion of England. The tortoiseshells, and allied species, are usually met with outside the woods, and not in the woods themselves.

Perhaps the most decidedly woodland species are the Fritillaries. The large Silver-washed Fritillary ${ }^{1}$ is to be seen in extensive woods, and seems to be fond of hovering about the blossoms of the bramble. The Pearl-bordered Fritillary, or Euphrosyne, is not an uncommon woodland butterfly, and in some woods is found in considerable numbers in May and June. The small pearl-bordered (Selene) is much less common, although it affects similar localities. Finally, the Heath Fritillary occurs in open places in woods, as well as on heaths, especially if heather be found there.

But wherefore "Fritillaries"? This group of butterflies is distinguished by the silvery spots and streaks with which the under side of the hind wings is adornẹd; while the upper surface is marked or chequered with black on a ground colour of goldenbrown, and in this device they obscurely resemble the old-fashioned liliaceous flowers called "Fritillary," whence it is conjectured that the name of the insects has been derived. The caterpillars are cylindrical 
and spiny, feeding chiefly on some species of violet. The chrysalis is humpy and irregular, suspended by the tail. Spiny caterpillars and suspended chrysalids are not confined to the Fritillaries.

The Ringlets are usually very modestly attired in brown of various shades, with a pair or more of round black spots on the wings not unlike an eye, hence called oscelli. The "Speckled Wood" is sometimes called the Wood Argus, ${ }^{3}$ or many-eyed, from the rows of black spots, resembling eyes, which adorn the wings. Its scientific name is Egeria, after a nymph celebrated by the Romans as the wife of Numa, who became so disconsolate at his death that she melted into tears. The caterpillars are warted, and not spiny, feeding on different kinds of grasses.

The Wall Butterfly is a lover of the sunlight, and is most addicted to lakes and sunny banks. But the most common of the family is the Meadow Brown, fluttering in sunshine and in shade over pastures and hill-sides, along the road, and occasionally straying into woods. One of the ancient deities of classical authors is said to have had fifty daughters called Nereides, and one of these was "Janica," whose name this butterfly bears.

The Ringlet ${ }^{2}$ has its upper surface almost entirely of a uniform sepia brown, with slight eye-spots. These are very distinct on the lighter brown under surface, surrounded by a very pale ring. The greenish caterpillar feeds on grasses during the night, and for that reason is seldom seen, unless sought after with a 
lantern amongst the long grass on the borders of woods.

The smallest of these brown insects is the small Heath, ${ }^{1}$ a little tawny-coloured butterfly with a single

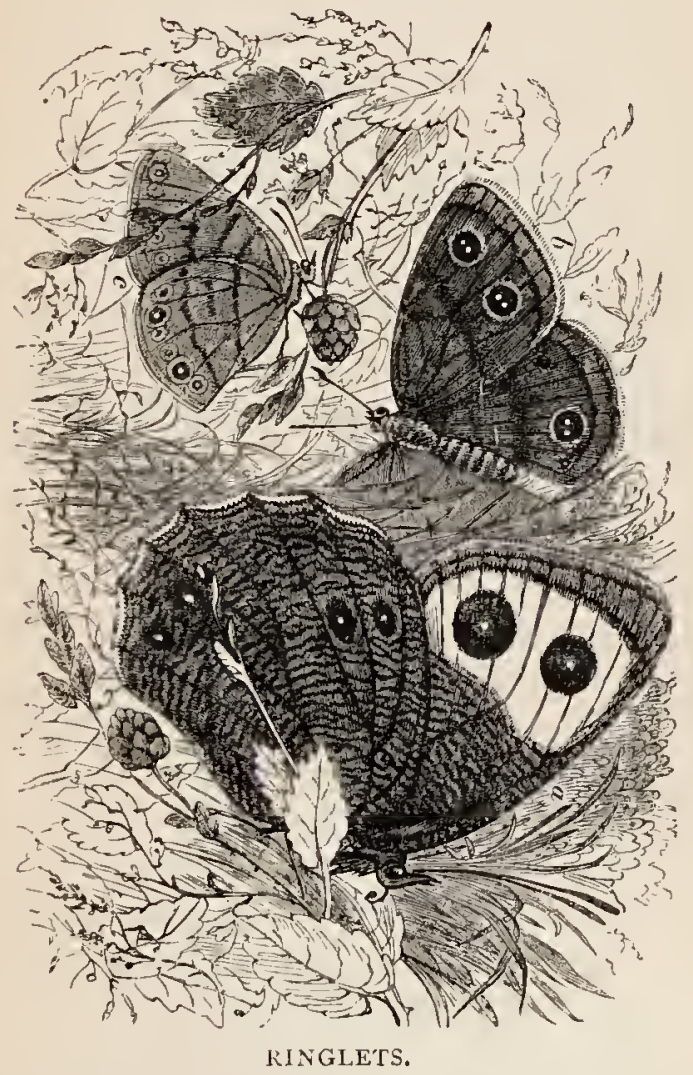

eye-spot on the outer angle of each fore wing. It flutters about heaths and rough places in company

1 Crnonympha Pamphilus. 
with little "Blues," and is not uncommon in open places in woods. Probably this modest little insect obtained its scientific name from a celebrated Macedonian painter named Pamphilus, who originated a law that only the children of noble parents should be permitted to learn painting. The relationship between an ancient Greek artist and a modest little brown butterfly is rather obscure.

When we were boys, and insect-hunters, the capture of a Hairstreak was considered an achievement worthy of note. The Hairstreaks ${ }^{1}$ are rather plaincoloured little butterflies, lovers of trees, true nymphs of the forest, distinguished by a small tail-like projection on the lower edge of the hind wings, which is sometimes reduced to a small tooth. The caterpillar is short and thick, shaped something like a woodlouse. That of the Green Hairstreak feeds on the bramble, that of the Purple Hairstreak on the oak, of the Black Hairstreak on the elm, and of the Dark Hairstreak and the Brown Hairstreak on the blackthorn. The whole of them are rather solitary in their habits, and local. One entomologist states that he saw on one occasion thousands of one species in a wood, but that he visited the same spot annually for thirteen years, and never saw a single specimen. It is unusual, nevertheless, to see many together, and in some seasons they are rarely seen at all.

The pretty little butterflies called the "Blues" are not all blue, sometimes only one sex is blue, and occasionally neither. They are jerky little insects,

1 Thecia. 
common in lanes and on heaths and downs at midsummer, especially in chalky districts. The under surface of the wings is very prettily spotted and marked, with scarcely a tint of blue, that colour being reserved for the upper surface. There is only one really woodland species, called the "Azure Blue,"1 and that is chiefly confined to the South of England and Ireland. The caterpillar feeds upon the flowers of the holly and ivy.

A little copper-coloured butterfly ${ }^{2}$ is often seen in company with the commoner blue ones, and sometimes without them, since it is found almost everywhere. It is scarcely more than an inch in expanse of wing, but often compensates in numbers for what is wanting in size.

A large, sluggish butterfly is sometimes to be seen flying about even whilst the snow is on the ground. It is of a bright, sulphur colour, and of solitary habits. This is the Brimstone, ${ }^{3}$ and the caterpillar feeds on the buckthorn. As the food plants are as often to be seen as an undergrowth in woods, in some counties, as in the hedgerows, it would be anticipated also that the mature insect is not uncommon in woods. It is scarcely possible to mistake this insect on the wing, although it is more lively during warm weather; but generally it has a lazy kind of flight, and juvenile insect-hunters find it sure game.

White butterflies-sometimes all of them are called cabbage butterflies-are lovers of gardens, fields, and

1 Lycana argiolus.

3 Gonepteryx rhanni.

2 Chrysophanus phlaas. 
lanes, and only stray into woods by accident, except one, which is called the Wood White, ${ }^{1}$ of a much more slender and delicate form, but by no means so common. Mr. Newman writes, "I have often watched its characteristic flight; one specimen will make its appearance, approach as it were on wearied wing, and if unmolested, pass by and go on out of sight; in a few minutes another will appear at the same spot, will follow the exact course of the first, and press onward in the same direction; and so on during the whole of a summer's morning, each seemingly bent on the performance of some inexorable duty, in which, however, despatch or hurry was totally out of the question."

The last of the butterflies are the "skippers," and these in some respects resemble moths, in others, butterflies. One of the most noteworthy differences, beyond structure, is that the "skippers" spin a cocoon in which to enclose themselves in the chrysalis stage, whereas the chrysalis of all the other butterflies remains naked, or exposed. These are little, modest coloured insects, with thick bodies, flying short distances at a time. The "grizzled skipper" ? frequents the borders of woods, and lays its eggs on the bramble and raspberry. The "large skipper" 3 frequents grassy places in and around woods. The caterpillar feeds on grasses. The remaining species are either local, or they occur in open places, and hence do not come within our limits. The number

- Leucophasia sinapis.

${ }^{3}$ Pamphila sylarunus.

2 Thymele alveolus. 
of different species of British butterflies is very small as compared with the moths, but they are much more generally known and recognized by the nonscientific, principally on account of their diurnal habits, and partly by reason of their brighter colours.

In a popular volume on British moths there occurs the following summary of the differences between moths and butterflies:-_." In the first place, moths fly by night instead of by day; in the second place, their bodies are not nipped at the middle, or waist, like those of butterflies; in the third place, their feelers, or antenna, have no knobs at the end like those of butterflies; and, in the fourth and last place, when a moth is at rest its wings are either laid on its body or folded round its sides, whilst those of a butterfly stand up straight, quite upright,

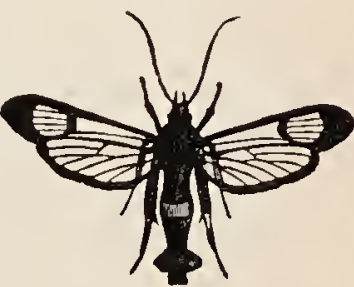

CLEARWING. and back to back." Bearing these four distinctions in mind, no difficulty need be experienced.

The Hawk-moths, or Sphinxes, have long, very thick bodies, and long, narrow wings. Once seen, never to be forgotten. We have taken the privet hawk-moth, and the lime hawk-moth, in woods, but they are not lovers of such localities; gardens are generally more productive. Caterpillars as large as the little finger, often of a pea-green colour, with a prominent horn near the tail, should be preserved and fed. By this means one may make the acquaintance of a hawk-moth. 
Moths with clear, transparent wings and striped bodies, not unlike wasps, may be seen flying about in the sunshine, unlike other moths. For these reasons none but an entomologist would dream of their being moths. The caterpillars, like white maggots, live in the solid wood of trees. Some prefer poplars, others willows, \&c.; and they change to a chrysalis in the galleries they excavate. We have heard of sixty or seventy being found in one piece of wood not more than three inches in length. These and two or three others which follow, cause great injury to trees.

The Goat-moth is one of the largest of our nocturnal Lepidoptera. The name of Cossus ${ }^{1}$ has been applied to it on the supposition that it is identical with the cossus of the Romans. The perfect insect is from two and three-quarters to three and a half inches in the expansion of its fore wings, which are ashy brown, clouded with brown, and marked with a number of transverse black, irregular streaks, forming reticulations. The hind wings are brown, with less distinct reticulations. The caterpillar is dull yellowish, with dark chestnut scales on the back of each wing, and when full-grown, as large as a man's forefinger. It feeds on willows and poplars, but will attack other trees. It bores into the solid wood, forming large, cylindrical channels, and does great damage, inasmuch as it is three years before it becomes full grown. Young trees are often rendered so weak by the channelling as to be blown down by the first gale. The cocoon is formed of chips of wood fastened together by a 
glutinous secretion, and lined with silk. It is constructed near the mouth of the burrow, a hole being cut through the bark to the surface, so as to enable the emerging moth to escape. This takes place in June and July. The moth is a heavy, lazy creature, and will sit all day long on the trunk of a tree which it has brought to destruction. In summer the presence of the invader is readily indicated by the exuvice of the chrysalis sticking out of the trunk or branch.

Pliny, alluding to the cossus of the Romans, says, "These worms even have now begun to be looked upon as delicacies by epicures, and the large ones found in the oak are held in high esteem; they are known to us by the name of 'cossis,' and are even fed with meal, in order to fatten them." Some think that these grubs were the larvæ of the stag beetles, others that they were the caterpillar of the goatmoth. Caterpillars are not now esteemed a delicacy in Europe.

The Wood Leopard ${ }^{1}$ is a smaller insect than the goat-moth, which it resembles in its habits. The caterpillar is only about an inch and a half long, of a yellowish colour, with four or five black spots on each side of the segments. It lives on various trees, ash, elm, oak, holly, beech, \&c. The males are evolved from the pupa in June, and the females a month later. The female measures a little over two inches across. The wings are rather transparent, and spotted with black. The males are active and lively in the evening, but the females are sluggish. The 
latter deposits as many as three hundred eggs in a mass. The young caterpillars when first hatched feed upon the bark, but they afterwards enter the solid wood. The tunnels ultimately constructed are as large as a swan's quill, and the presence of the excavator may often be detected by the sawdust outside.

The Buff Tip, ${ }^{1}$ when its wings are expanded, measures from two and a half to three inches wide; the wings are of a light ash grey with a large, nearly round spot at the tip. When this moth appears in May or June it sits with its wings close to its body, and in this condition it resembles a stick, the cut end represented by the terminal spots. The caterpillar feeds on the lime, and is dark brown with longitudinal yellow stripes. Other trees often come in for a share of its favours, and as it attains two inclies in length when full-grown, the quantity of food it requires is considerable. We have given a more explicit description of these insects than space will permit us to do for others, because they are so common, so destructive, so thoroughly woodland insects, and of such a size that they cannot well be overlooked.

It may be remarked here that some insects when at rest so greatly resemble the vegetation amongst which they are found as to be scarcely distinguishable from it. We do not allude alone to the remarkable "leaf insects" and "stick insects" of tropical countries, of which specimens may be seen in the India Museum at South Kensington, but to the less pretentious insects of our own lands. Out of fifty- 
two autumn flying moths it has been noticed that a large proportion are of various tints of yellow and brown, so as exactly to match with the "sere and yellow leaf"; while in winter they are of grey and silvery tints like the washed-out leaves and grass, the fog and the hoar-frost which give a tone to every landscape at this season. One of the most curious of these resemblances, pointed out by Mr. Alfred Wallace when writing of the "Disguises of Insects," is that of the Buff-tip moth. This insect closes its wings so as almost to form a cylinder, and on the tip of each wing is an oval yellowish spot, edged with a dark brown double line. The wings are greyish and hoary, and the head again is much contracted beneath the large thorax, which is also of a buff colour, with a double brown marginal line. The result of this arrangement is that the insect looks at first sight like a piece of stick, one end being broken off nearly square, the other end more obliquely, and as it often rests on the ground among grass or on leaves, it may easily be mistaken for a piece of a broken branch which has fallen to the ground.

The Lappet Moth when at rest resembles very closely a small bunch of dead leaves, and at a little distance could hardly be taken to be a moth, so curiously does it spread out its hind wings so as to project beyond the others. Many such instances have been indicated, and many others probably remain to be observed even amongst our commonest insects.

Readers need scarcely be reminded that the beautiful silken fabrics which are the pride of manufacturers 
are produced by a moth, or at least by the caterpillar of a moth, called a silkworm, which feeds on mulberry-leaves. This is not a British insect, but we have others which have a like habit of spinning a silky cocoon in which the transformation takes place. The silk of which these cocoons are composed is not of the beautiful texture of that of the true silk-moth. In other countries the silk of wild moths is turned to a useful purpose, but we have none capable of being successfully cultivated for their cocoons.

The moth called the Oak-Eggar ${ }^{1}$ is one of the silkspinning moths, which forms an egg-shaped brown cocoon. The moth is from two to three inches in expanse of wing, the male chocolate-brown, and the cemale tawny, with a large woolly body. This is a very common insect, and is developed from a large densely hairy caterpillar which rolls itself up when touched. Another cocoon-spinning moth is the FoxMoth, ${ }^{2}$ which is similar in appearance, and has also a large hairy caterpillar, which feeds on the bramble.

The Drinker ${ }^{3}$ belongs to the same family, and is said to have derived its name from its hairy caterpillar sucking up drops of moisture from the leaves on which it feeds. Larger than this is the Lappet, ${ }^{4}$ but not so common. The caterpillar feeds on the sloe and willow. The Kentish Glory ${ }^{5}$ is certainly a splendid moth; it is rather given to flying in the daylight, but is not very easily caught. It spins a brown cocoon of rather a loose texture, amongst fallen lenves.

1 Lasiocampa quercus.

2 Lasiocampa rubi.

3 Odonestes potatoria.
4 Gastropacha quercifolia.

5 Endromis versicolora. 
The insect which approaches nearest to the wild silk-moths of India is our "Emperor Moth," " with a large eye-spot near the centre of each wing. It is much more abundant than the Kentish Glory. The caterpillar is green, and feeds upon willow, blackthorn, and other plants. Its cocoon is pear-shaped, with an opening at one end.

Observers of insect life will have observed a snowwhite moth hanging about hedges, and even the undergrowth in woods, which is very sluggish in its habits; so lazy that it may be caught with the fingers. If it falls down in a clumsy attempt to take it, then it gathers up its legs and lies still, as if to simulate deatl. There are two or three species of these sluggish white moths, and one of them has a tuft of brown hairs at the tail, ${ }^{2}$ and another much more common has a tuft of yellow hairs at the tail. ${ }^{3}$ 'These, and some others, spin a slight web, on which their eggs are laid, and the chrysalis is hairy. Of the former of these moths it is recorded that in 1783 the caterpillars were so numerous and destructive in the neighbourhood of London, that "subscriptions were opened to employ the poor in cutting off and collecting the webs; and it is said that not less than eighty bushels were collected and burnt in one day in the parish of Clapham. And even in some places prayers were offered up in the churches to avert the calamities of which they were supposed by the ignorant to be the forerunner." We transcribe this account as it is

1 Salurnia pavonia minor.

${ }^{3} P$. auriflua.

2 Porthesia chrysorrhara. 
recorded. In times past there was undoubtedly a prevalent belief that an unusually large number of insects making their appearance was a presage of coming evil.

Insect-hunters, like anglers, adopt manœuvres to beguile their prey, and of these the most universal is called "sugaring." It consists in smearing the trunks of trees on the borders of woods with a mixture of coarse sugar dissolved in beer and flavoured with a spoonful of rum. This is done at dusk, and shortly afterwards the trees are visited in turn with a "bull'seye" lantern, when moths will be found busy at the sugar, and are then transferred deftly into pill-boxes. The moths caught by this method in the greatest number are the sombre-coloured, thick-bodied "Noctuas," which are almost exclusively night-fliers. Some few are more brightly coloured, but the rule is in favour of funereal tints. As a rule, the fore-wings entirely cover and hide the hind-wings when the insect is at rest. The tracery of the fore-wings is rarely continued on the hind-wings, which latter are commonly of a uniform colour, except a marginal band or line.

One of the most common of these moths is the Grey-dagger, with dagger-like marks conspicuous amongst the delicate tracery of the fore-wings. The caterpillar is a tree-feeder, and the chrysalis is found in the cracks of the bark. The Wainscots are all very deficient in characteristic markings. The large and small yellow underwings are common everywhere at midsummer, and are favourites with young entomologists because they are large, shorry, and readily 
distinguished. None are more ubiquitous than the "Silver Y," with a bright silvery mark on the forewings not unlike a " $y$," or a Greek gamma $(\gamma)$. It is difficult to fix the limits of these common species; gardens or woods, they seem to be equally at home everywhere. Our space compels us to be content with a few suggestions, and then to hurry on.

Caterpillars are in themselves a study, and a very interesting one. Some are hairy, and some smooth. Of the hairy kinds, some have the hairs rather equally distributed, others have them collected in tufts. Almost every large group of moths exhibits some peculiarity in the caterpillars; hence the practical entomologist will be able to determine the group to which the moth resulting from any given caterpillar belongs. One large group of caterpillars have this peculiarity, that the legs are confined to the two extremities, so that in walking they proceed by a series of loops, projecting their heads forward, then drawing up their tails they form a loop, and for this reason they are called "loopers." The insects developed from these caterpillars have slender bodies and large wings, the latter usually remaining expanded when the moth is at rest. One of the largest of these moths is the pale, sulphurcoloured swallow-tail moth, ${ }^{1}$ which flies along hedges at dusk. Probably the commonest is the "Yellow Shell," 2 which will be found in every bush. Nearly as common is the large black and white "Magpie," especially in gardens on gooseberry and currant

1 Oxtapteryx sambucaria.

${ }^{2}$ Camptogamma bilineata. 
bushes. These common examples will illustrate the general appearance of the moths developed from looping caterpillars. We have in Britain more than two hundred and fifty species belonging to this group. The caterpillars of many of them feed on the leaves of forest trees and shrubs, as well as the herbaceous plants which grow beneath them. Some of the moths are called "Pugs," others are "Carpets," others again are called "Waves" and "Thorns." To recognize them and their differences must be a work of time and experience.

By striking the branches of an oak in autumn we shall certainly disturb a small pea-green moth which flutters a little while on the wing, and then settles again, perhaps in some position in which we can gaze upon it leisurely, admire its uniform colour, so nearly like that of the leaves on which it feeds, its peculiar form when the wings are closed, and thus obtain some rude idea of the variety of three hundred different species which inhabit the British Islands. These are called Tortrices, and the larve of some of them are very destructive. The one to which allusion has just been made sometimes entirely strips an oak of its leaves in June. Others attack fruit-trees, and in France one is destructive to vines.

It is not unusual to observe two neighbouring leaves on a shrub fastened together, one over the other, by means of silky threads as fine almost as a spider's web. If these are separated, the small larvæ of one of these Tortrices will probably be found busy between them. In the decaying fungi which are found adhering to stumps, larvæ like maggots will be 
seen in numbers. Of these some will belong to beetles, but others will, in many instances, develop into Tortrices. It is difficult for the unpractișed eye of a person who is not an entomologist to determine at once whether any one of these larvæ belongs to beetles or moths; but there are characters which enable the practised eye to detect the difference at once. If we look down a list of the British species of the Tortrices, we shall be surprised to see how variable are the homes and haunts of these diminutive creatures, and what widespread injury they must inflict on vegetation if there were not also natural checks to their increase in insectivorous insects and birds, continually at work reducing their numbers.

There exists a very strong prejudice, in domestic circles at least, against all the small moths, the little, sombre-coloured insects which flutter about everywhere in the summer-time, and, when fully expanded, are not larger than one's finger nail. All of these are called Clothes Moths, and a war of extermination is ever going on against them in all wellregulated families. It must be admitted that the caterpillars of some of the Tineina, as they are called, feed on clothes, sofa linings, and other articles of personal use; but of the six or seven hundred British species this number is comparatively few. Many of them are in this stage leaf-miners, that is, the caterpillars, or maggots, eat a gallery under the cuticle of living leaves, ornamenting the leaf in a manner peculiar to each species. These are the woodland species, which appertain to our subject. 
Our best authority thus writes: "Sometimes the same leaf will be mined by two or three species, each of which imparts to the leaf a mark, recognisable by the initiated, indicating what species has fed on the leaf long after the larva has itself departed. A mined leaf is hence inscribed with hieroglyphic characters, and the key wherewith to decipher these is obtainable by patient and continued observation.

"Bramble-leaves may frequently be found with two different kinds of mines; in one, the leaf remains perfectly flat, and a long, slender, serpentine gallery winds its way across the leaf, and generally attains a length of from two to three inches. This mine, which is scarcely visible whilst the larva is still at work, the discoloration being then so slight, becomes very conspicuous after it has been long deserted, the dry, loosened upper skin eventually becoming almost white, and contrasting strongly with the dark green colour of the leaf. The creature that makes this mine is a small, pale umber, semi-transparent larva, with no real legs, and when full fed it crawls out of its mine, and proceeds to some convenient corner, in which it spins a small, flat, brownish-green silken cocoon, from which, at the end of two or three weeks, there emerges a brilliant little moth, ${ }^{1}$ about a quarter of an inch in expanse of the wings, of which the fore-wings are of a rich golden brown, tinged with purple beyond the middle, and with a nearly straight, pale, golden band beyond the middle."

One of the Tineina, called the "Apple-tree Moth," 2 attacks apple-trees and hawthorns in spring. The

1 Nepticula aurella.

2 IJj, 
whole tree soon appears to be covered with a mass of web, which swarms with little caterpillars. In a short time every green leaf on the tree is consumed. The caterpillars reign supreme. In a Journal of Arts, published in 1827 , we read of an effort made in Bavaria to turn these little weaving caterpillars to practical account. "The larvæ of Tinea padella have been directed by M. Habenstreet, of Munich, so as to work on a paper model suspended from a ceiling of a room. To this model he can give any form and dimensions, and he has thus been enabled to obtain square shawls, an air balloon four feet high, and a woman's complete robe, with the sleeves, but without seams. One or two larvæ can weave a square inch of cloth. A great number are of course employed, and their motions are interdicted from the parts of the model not to be covered, by oiling them. The cloth exceeds in fineness the lightest gauze, and has been worn, as a robe over her court dress, by the Queen of Bavaria." 


\section{CHAPTER XI.}

ANTS, WASPS, AND BEES.

ONE of the orders of British insects is called by naturalists Hymenoptera. This is characterized by the possession of two pairs of clear, membrane-like wings and a peculiar instrument at the posterior extremity of the females, which in the saw-flies is a saw, in the gall-flies bristles, in the ruby wasps a tube, and in the ants, bees, wasps, and sand wasps it is a sting. The gall-flies will receive notice in connection with the galls which they cause; the ants, bees, and wasps being the most interesting of the remaining groups demand attention here. The other groups are of more interest to the scientific entomologist.

Ants have been a favourite theme for authors, and from Solomon to the present time have been appealed to as furnishing lessons for the human race. Unfortunately in some instances facts have not entirely supported the elevated views which have prevailed concerning them; yet, notwithstanding this, they are an interesting and instructive group of insects, well worthy of minute study. Some species prefer woods, whilst others affect gardens, and even houses, but their habits and domestic economy are similar in all.

It is reported of the celebrated Timour, that being 
once forced to take shelter from his enemies in a ruined building, he sat alone many hours, and, desirous of diverting his mind from his hopeless condition, at length fixed his observation upon an ant, which was carrying a grain of corn (probably a pupa, which somewhat resembles a grain of corn in shape and size) larger than itself, up a high wall. Numbering the efforts it made to accomplish this object, he found that the grain fell sixty-nine times to the ground, but the seventieth time it reached the top of the wall. "This sight," said Timour, "gave me courage at the moment, and I have never forgotten the lesson it conveyed."

Huber narrates the results of his watching the labours of an ant on a rainy day. The insect began by scooping out a groove of earth about a quarter of an inch in depth, kneading the earth which it removed into little pellets, and placing them on each side of the groove, so as to form a kind of wall. The interior of the groove was beautifully smooth and regular, and when completed it looked very like a railway-cutting, and performed a similar office. After completing this task, it looked about and found that there was another opening in the nest, to which a road must be made, and straightway set to work upon a second sunken path of a similar character, parallel to the first, and being separated from it by a wall a third of an inch in height. After relating this, the Rev. J. G. IVood compares the labour of this ant with what would be an equal amount of work for a man. He must have excavated two parallel trenches, each of seventy-two feet in length, and four feet six inches in depth. He 
must have made bricks from the clay he dug out, and with them built a wall along each side of the trenches from two to three feet in height, and fourteen or fifteen inches in thickness; and, lastly, he must have gone over the whole of his work again, and smoothed the interior until it was exactly true, straight, and level. All this work must also have been done without the least assistance, and the ground must be supposed to be filled with huge boulders, and covered with tree trunks, broken logs, and other impediments.

That ants are industrious, persevering, and ingenious there can be no doubt, but the recent careful observations and experiments of Sir John Lubbock prove that these traits have been overrated. He has shown that they would not raise a mound of earth half an inch to reach an object which they desired. That they would take a long and circuitous route rather than drop or leap the length of their own bodies; that if a straw were misplaced along which they had travelled for food, they did not attempt to replace it; that, in fact, they did not in these things exhibit as much intelligence as is shown by many other creatures.

Franklin believed that ants could communicate their thoughts or desires to one another, and confirmed his opinion by experinent. In like manner Sir John Lubbock has demonstrated that ants do communicate with each other, that they recognize each other, and their mystic signs consist in the rubbing together of their antennæ. He has shown that ants will return to their nests and bring with them other ants to share the food they have found, but that they were unable to direct them, except by accompanying them; that 
they pursued their course partly by sight, and partly by scent. Ants will communicate with each other, but no evidence has been obtained by recent experiments that they can direct their companions to food except by accompanying them.

It has been shown that ants are affected by different coloured lights and media; that they are very sensitive to violet, and would not go under glass of that colour if it could be avoided, for whilst during an experiment 890 ants went under glass of a red colour, only five were found under violet. It is also demonstrated that wasps, as well as bees, are capable of distinguishing colour.

Ants belonging to different nests are generally enemies, but M. Forel says that when they first quit the pupal stage they do not distinguish friends from foes, though three or four days are sufficient for them to do so. He is convinced that ants recognized their companions after a separation of four months, but believes they would not do so for more than one season. Lubbock proved that for more than a year ants remembered their old companions, and received them amicably whilst they attacked strangers. That old acquaintances were evidently recognized is clear, because they were never attacked, while any ant from a different nest, even of the same species, would be set upon and killed if she did not succeed in escaping from the nest. In one case the ants had not seen one another for more than a year.

Forel asserts that if an ant is a little ill, or slightly wounded, she is carefully tended by her companions, while those dangerously ill or wounded are carried 
out of the nest to die. This is an interesting trait in ant-character if true; but although there may be "good Samaritans" amongst ants, the conclusions from Lubbock's experiments are against its truth. On one occasion a wounded ant was placed on her back, near some syrup, soon a companion came up, and recognized her, then went to feed at the syrup. Three other ants did the same, none of them taking any further notice of her. One ant was left in water till to all appearances drowned; she lay exposed for half an hour before she recovered, but during this time an ant from the same nest passed her eighteen times without taking any notice of her.

This experiment being again repeated, one ant passed thirty times, and another twenty-eight times without taking any notice. On one occasion an ant lost the terminal portion of both antennæ, and seemed to have lost her wits. She was put into her nest, but the others took no notice of her; she then retired into a solitary place, where she remained for five hours without moving. She came out, and remained out all day; on the following morning she was dead.

Huber states that the Amazon ants are so dependent upon their slaves as to perish in two or three days if separated from them. That this is the case has been shown by subsequent observers. It is of no use giving them food; they will not touch it, or rather they walk carelessly over it, smear their legs, and die if a slave is not put in to clean and dry them. Lubbock found that he could keep even a single Polyergus alive for more than three months by giving her a slave for about an hour a day to attend upon and feed her. 
To show how persistently Sir John Lubbock has studied the history and mystery of ant-life, he has stated that he possesses ants which are five years old. It may safely be asserted that no insects so amply repay study and afford so much interest as those which compose the order to which ants belong, including as it does the bees and wasps. We have only hinted at some of the remarkable facts which are to be collected from the elaborate details of recent experiments. ${ }^{3}$ These form but a small portion of the domestic economy of these minute but extraordinary insects.

In all that concerns British bees the works of Mr. W. E. Shuckard contain such a fund of information that we must at once admit the source whence much of our information has been derived. It is confessedly a section of entomology in which there are but few active workers, and the life and powers of man are too circumscribed to permit of any one individual becoming more than superficially acquainted with many of the elaborate leaves in the Book of Nature. The bees and wasps are ratler lovers of sandy and open spots than woods and forests, nevertheless many of them will often be found there, and it would be considered a grave omission if we were wholly to exclude them from our generalizations.

A pretty little bee, called Ceratina, on account of its bearing a small horn between its antennæ, is rare, but has been found plentifully in some localities. It

1 Recorded in the "Journal of the Linnean Society" from 1874 to 1878 . 
excavates the pith of bramble or briar sticks, in which its eggs are laid. The prevalent colour of the bee is black or brown, with a metallic tinge. The only flower it has been known to frequent is the Viper's Bugloss.

The bees of the genus Nomada have been called Wasp-bees, because of their general resemblance to wasps in colour. They may be found hovering about hedgerows or banks. The colours are red or yellow, mixed with black in bands or spots. It is curious that these are really parasitic bees, each species having its peculiar object of attack.

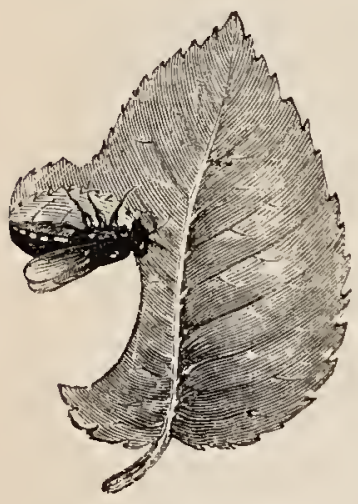

THE LEAF-CUT'TER BEE.

Amongst the most interesting are the Leaf-cutter Bees, of the genus Megachile. 'They are so called from the habit they have of cutting pieces from the leaves of various shrubs and trees, for the purpose of lining their nests. One species burrows in decaying wood, and makes use of the cuttings of rose-leaves and the leaves of the Mercury. Another species bores into sound oak and mountain ash, as well as rotten elm, and uses cuttings of elm-leaves to line the nests. This last is the largest of indigenous species, and is found abundantly round London on the flowers of the thistle. The proceedings of these bees are curious. After preparing a cylindrical tube in wood or the ground, the insect starts in search of material 
for its lining. Having fixed upon the preferred plant, rose, or willow, or whatever else it may be, it alights upon the leaf, and fixing itself upon the edge, it holds it with three legs on each side, then, using its mandibles as a cutter would his scissors, this ingenious little creature plies the tools it is furnished with by nature. The oval, or semicircular cutting being thus speedily dispatched, with the legs still clinging to the surfaces, the insect biting its way backwards, the piece cut off necessarily remains within the clutch of the legs, and when about falling, the rejoicing labourer expands her wings, and flies off with it, with a hum of delighted triumph, the cutting being carried perpendicularly to her body. When she reaches the mouth of the burrow, she rolls the cutting to its requisite tubular form, and thrusts it forward to the bottom of the cavity. She withdraws backwards, again flies off to the same plant as before, makes fresh cuttings, and so continues until the lining of the burrow is complete. Another duty has now to be performed, for which all the previous labours have been undertaken,--provision for its young. Honey and pollen are gathered from different kinds of thistles, and the nest is filled with it to within a line of its top; the egg is then deposited, and the coating of leaves which surrounds the cell secures the store from lateral absorption, although the mixture is rather more fluid than usual. The cell has now to be closed, and the artificer, knowing the section of the cylinder is circular, again flies forth, and cuts the leaf again in that form, and this process is repeated three or four to five or six times. The separation between the cells is consolidated, and the whole pro- 
cess is repeated until the completion of five or six cells necessary to fill the tube, when another is constructed with the same routine, until her store of eggs is exhausted. The outer cell, after being closed in the usual way, is filled up with earth.

Another wild bee makes provision for its progeny in a similar manner, but with different materials. The Anthidium, instead of making its own burrow, takes one already made by the boring larvæ of other insects. This it lines to a suitable depth with the cottony down which it scrapes from the leaves of woolly-leaved plants. This down is collected by aid of its mandibles, is rolled up in a little ball, and then carried off to the nest. This operation is continued until sufficient is accumulated for the purpose. She then forms cells in it in succession, gluing the material together to resist the escape of the pollen and honey with which it is to be filled. The cell is closed after the deposit of the egg, and another similar cell is proceeded with until the cavity is filled, or the store of eggs exhausted.

The Carpenter Bees belong to the genus Chelostoma, and are abundant in some localities. They have strong mandibles, which cross each other when at rest. Sometimes they appropriate burrows already formed, at others they construct tubes for themselves. When they drill their own cylinders they are extremely persevering in their execution, and in the process, the fine sawdust which they make is drawn from the bottom of the cavity, passed beneath them, and thrown out of the cavity by means of their hinder-legs, for they cannot turn round in the cavities they 
excavate. Having drilled a cavity, they collect a store of provender for their prospective young, on which they deposit the egg. They then collect a small quantity of clay mixed with sand, which they knead together by the aid of a viscous secretion which they disgorge, and this forms a concrete that hardens rapidly and firmly. With this substance rolled up in a ball within their mandibles they fly back to their cavity and close the cell, separating it securely from the next store of provision which is placed upon it and upon which another egg is laid. Thus a second and a third cell are formed and sealed up, and so on, until the cavity is filled.

Two beautiful little Hymenopterous insects (Chrysis ignita and Chrysis cyanea) are parasites, bred at the expense of these Carpenter Bees.

The Mason Bees, of the genus Osmia, domicile themselves in old walls, sandbanks, and decaying willow stumps. They have been called Masons from the habit they have of agglutinating particles of sand or earth, mixed with minute pebbles scarcely larger than grains of sand, or raspings of wood combined in the same manner with a secretion which they emit, and of which they form their cells. These cells are rather rough externally, according to the nature of the material of which they are composed, but they are very smooth within. Where the cavity is restricted, they place them end to end, but where it is more roomy they affix them side by side, adapting themselves to the circumstances in which they may be placed. The insects may be found frequenting many linds of flowers, especially those which are abundant 
around the locality they inhabit, especially the flowers of composite plants, such as the Hawkweeds.

One other group of bees, and we have done with them. These are the largest of British species, and are called by the generic name of Bombus; perhaps "Bumble-bees" is a corruption of this name. There are nearly twenty species in this genus, which, except the Honey-bee, are our only social bees. The most interesting part of their history is that which concerns the structure of their nests. This is particularly the case with those called "Carder bees," which felt and plait the filaments of moss to form their home. Such species select a spot close to an abundant supply of material, which they make pellets of. To these nests a long arched passage is formed of the same material, large enough to permit the free passage of the bees to and fro. To construct this the bees form a chain one behind the other from the growing material to the entrance of the passage, all their heads being turned towards the moss and their backs to the nest. The first bites off the raw material, rolls and twists it, passes it to the second, by whom, and by the succeeding ones it undergoes further manipulation, and at the termination of the chain and commencement of the passage another bee receives it and conveys it along to the interior, and then either applies it herself, or passes it to others to be applied where required. A vaulted covering and sides are thus formed within the cavity, by plaiting or twining together these sprigs of moss, and the inside is further strengthened by being plastered with a coating of false wax, which smells very much like true wax, and 
with which the loose filaments of the moss are combined, so that one cannot be separated from another without tearing the whole in pieces. In this way some of the species build. In all the communities, which vary in size, the domestic arrangements are the same; the females and neuters are the labourers, performing all the building, and rearing the young. The function of the males is restricted to the perpetuation of the species.

There is scarcely a more industrious or instructive group of insects to be found than the bees, even exclusive of the hive-bee, which has ever been indicated as the pattern of industry and ingenuity. Even the brief observations which the limits of this work permit us to make must be sufficient to establish this fact. Let us hope that it may induce some who have never paid any attention to their habits hitherto, to exercise an observant eye on the economy of these humble creatures, which may furnish them with silent and simple lessons for their guidance through life.

Wasps are generally grouped, for the purposes of study, in two groups, the solitary wasps, and the social wasps. The solitary wasps divell apart by themselves, and the social wasps in communities. The former very much resemble the latter to the untrained eye, and may be seen in summer flying about flowers, preparing for the great operation of their lives, the perpetuation of their species.

The social wasps are in part builders in the ground, as in sandy banks, and part on trees or externally. The tree wasps found in this country consist of but three species, and of these one is very rare, so that 
practically there are but two social wasps which are arboreal in their habits. These construct nests upon a similar plan, and with a like material, which is manipulated with care and ingenuity.

Wasp-paper, or the substance of which the nests are composed, is made up of various substances; sich as fragments of wood or bark, paper-cuttings, vegetable filaments, \&c. To a certain extent the cohesion of these filaments is mechanical, for a kind of felting or interlacing may be traced; but the materials are for the most part held together by the mucous secretion with which they are worked up into pulp. Wasps may be watched at a row of palings on a summer morning scraping off fibrils with which to construct their nests, forming them into pellets, and conveying them to the place where the nest is being constructed. Dr. Ormerod says that when a wasp comes home laden with the building materials, she does not immediately apply them, but enters the nest, and then, after about half a minute, she emerges and sets to work. Mounted astride on the edge of one of the covering sheets, she presses her pellet firmly down with her forelegs till it adheres to the edge, and, walking backwards, continues the same process of pressing and kneading till the pellet is used up, and her track is marked by a short, dark cord lying along the thin edge to which she has fastened it. Then she runs forwards, and as she returns again backwards over the same ground, she draws the cord through her mandibles, repeating this process two or three times till it is flattened out into a little strip or ribbon of paper, which only needs 
drying to be undistinguishable from the rest of the sheet to which it is attached.

The outer walls, or shell of the nest, are first constructed, so that it is difficult to watch the processes by which the cells are formed. The material appears to be the same as the external shell, but thicker and more compact, and the nests are often more irregular than the comb constructed by the hive bee.

The Hedge Wasp ${ }^{1}$ generally builds in low bushes or hedgerows, but sometimes in trees. The outline of the nest is pear-shaped. The opening is on one side, and often, instead of a simple hole, there is a kind of porch, in which the sentinel, whom it is the habit of this wasp to post, mounts guard.

The Wood Wasp ${ }^{2}$ makes a nest of quite a distinct character. It is, from the first, of a ball or bell shape. At the bottom is a round hole, with the edges slightly turned out. Over this are laid one or more separate hoods of the same slight, graceful construction, but not reaching so far down as the mouth of the bell in which the second coat terminates. The resemblance of this nest to a toy bell led to this insect receiving the name of the Bell Wasp. Finally, this nest assumes a pear-shape with a central aperture.

The social life of wasps is a subject of interest, inasmuch as it differs in some points, whilst it resembles in others, that of ants and bees. Quoting again from Dr. Ormerod, he says, "When a wasp 
appears with her crop full of fluid, she becomes immediately a centre of attraction. Two or three gather round her, and take up the fluid as she gradually lets it drop out on the upper surface of the comb. Then the larvæ are visited in their cells, and take their food in the most sisterly way, from mouth to mouth, till the supply is exhausted, and the nurse is at liberty to go away and replenish her crop. The solid food which is brought in cannot be so easily distributed, but, however it is portioned out, there is never any quarrelling. Strong as the instinct is in wasps to snatch and hold their own against all the rest of the world, yet no feeling of resentment seems to be aroused by the loss of their prey. Once gone, whether to friend or foe, it is lost, and they make no angry attempts to recover it.

A butcher often revenged himself on the wasps which stole his meat, by clipping their wings. Long practice, with a sharp pair of scissors, had made him so dexterous that he could snip off a wing without interrupting the wasp at her work. When the wasp had cut off a piece of meat she tried to fly away with it, but finding she could not fly, thought the piece was too large to carry, and cut it in half; and so she went on, cutting the meat smaller and smaller, as long as the butcher would let her, attributing her inability to fly to the size of her burden, not to the mutilation of her wings. ${ }^{1}$

Although, in their popular aspect, the ants, bees,

' Ormerod's "Natural History of Wasps," p. 253. 
and wasps are the most generally interesting of all those termed Hymenopterous insects, yet they are only a portion of the order to which they belong. There are, for instance, the Ichneumons, most strange-looking flies, with thin, attenuated waists, and tails furnished with long and strong ovipositors. They are veritable cuckoos amongst insects, for they have a habit of puncturing other living insects, and depositing eggs in their bodies; these, when hatched, live at the expense of, and ultimately devour, their host. We should be afraid to venture a guess at the number of species of the smaller Hymenopterous insects which are true parasites. In this we recognize one provision for keeping in check the enormous production of flies of all kinds, which otherwise might so swarm as to devour every green thing. There is scarcely a gall insect which produces galls upon plants but has its peculiar parasite, generally of these four-winged flies, and thus they become parasites of each other, for a great number of galls are the production of this kind of insect. Bees and wasps have their parasites, in what might be termed. "cousins," of the same family. In fact, parasitism is carried to an extreme amongst insects just laudecl for sociable qualities, and for the possession of a large share of instinct almost bordering upon intelligence.

Another group consists of "Saw-Flies." Some of these are very destructive in pine woods, and one ${ }^{1}$ is often very troublesome in our plantations. After 
pairing, the female looks out for a place where she can safely deposit her eggs, from eighty to one hundred and twenty, and where she thinks they may find suitable nourishment when hatched into caterpillars. This food is either the foliage of the end of the last year's shoot, or that of the shoot not quite expanded. When prepared, she makes an incision the whole length of the leaf, with her ovipositor, and hollows out the leaf from the edge towards the middle, so that one or two eggs can lie in the narrow space; the eggs are then laid in it, and closely covered up with a tough, resinous material, mixed with the substance scraped from the leaf. Thus she proceeds until all the eggs are deposited on several leaves. After from sixteen to twenty-four days the caterpillars appear from the eggs, about a line long. In this condition the insect is a great glutton. A full-grown caterpillar requires from six to twelve strong, healthy leaves daily, which it consumes from the point to the sheath. According to Müller ${ }^{1}$ these caterpillars were so numerous in $\mathbf{1} 819$, in some of the pine forests of Franconia, that none of the foliage could be seen for them. They fell in thousands from the trees, collected themselves in heaps, not unfrequently of the size of a man's head, and marched in dense flocks from those trees which they had stripped to those that were still green. According to the calculations of this writer, a pair of these insects would, in ten years, if unchecked, produce an offspring of nearly two hundred thousand

1 "Gard. Chron.," I852, p. 708. 
billions, a number for the support of which all the German forests would not be sufficient.

The Saw-flies are so numerous and so common that it would be easy to quote many examples, but one or two instances must suffice. During the winter months certain oval brown cocoons will be found adhering to the twigs of the whitethorn. These are the cocoons of an insect somewhat resembling a bee, but with a longer body and legs. ${ }^{2}$ It is of a blackish colour, with ashy, orange hairs. By means of their curious saw-like apparatus the females form small channels in the tender branches where they deposit their eggs, the larvæ being hatched in August, when they are of a pale dull-green colour. When alarmed they discharge a clear, greenish, watery fluid from the lateral pores, placed above the spiracles, to a considerable distance. The object of this is evidently to drive off parasitical enemies, in which it is not always successful, for it is common to find the inside of the cocoons filled with the small cocoons of an ichneumon, sometimes of two different species, which have flourished at the expense of their host.

Another species with a black body and black legs, frequents not only the plum and cherry, but also the oak. ${ }^{2}$ The slimy grub, after feeding to the full on the leaves of these trees, descends into the ground to undergo the change into the pupa state, and the perfect fly makes its appearance at the end of July.

In association with these may be named another

1 Tenthredo (Trichiosoma) lucorum.

- Selandria alra. 
small black sawfly which lays its eggs upon roses in gardens, from which the grubs are hatched in May. These larvæ devour the upper cuticle of the leaves, so as to impart to them a blighted appearance. ${ }^{1}$ They are little, yellowish-green caterpillars, about half an inch long, with an orange-coloured head. 'When these have changed their skins several times and arrived at their full size, they descend into the ground and rest in little cells during the winter as pupæ, making their final appearance as perfect flies in the spring.

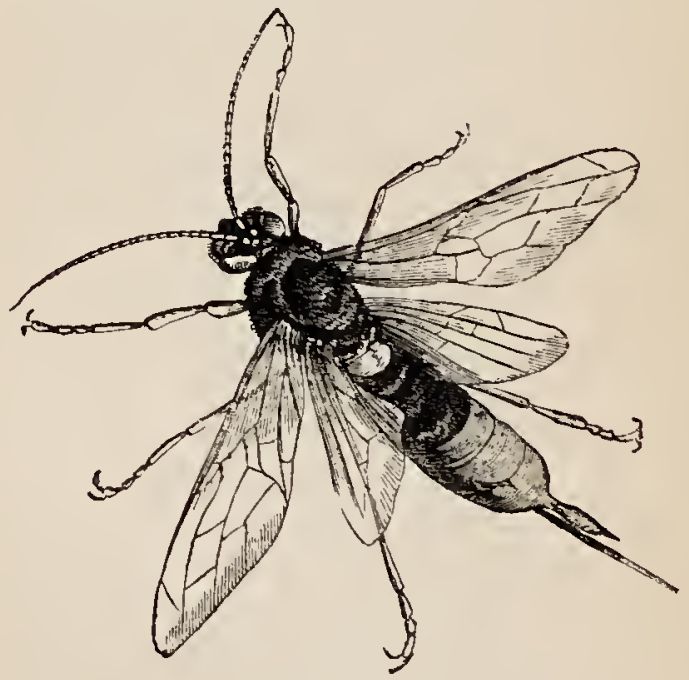

SIREX.

A most formidable-looking insect, mistaken by some people for a "hornet," occasionally even finds its way into our houses, the larvæ being brought in with the wood it inhabits. ${ }^{2}$ The larva is like a large maggot from an inch and a half to two inches in ' Selandria Atthiops. 2 Sirer gigas. 
length. The female insect bores a hole with its strong ovipositor in the bark of the fir, in which a single egg is deposited. After seven weeks the larva has attained its full size, when it is usually buried six inches deep in the wood; here it remains a long time in a pupa state, and as the eggs are usually deposited in cut trees in preference to growing one, the pupæ are often found in squared and cut timber. The yellow body of the female insect is terminated by the sheath of the ovipositor, which the uninitiated are prone to regard as its sting; and hence the insect always inspires dread. As the female will lay some hundreds of eggs during the season, it is by no means a rare insect, but must be sought amongst pine-trees. Larch posts and palings are subject to its attacks. Strange stories have been told of this insect, but they bear so little of the impress of veracity that it were better not to repeat them.

There is one feature of the wings in many of these insects which will interest the microscopist. This consists in the row of hooks with which the upper edges of the hind wings are furnished. Not alone one feature but many await the investigator of their minute structure; the saws of the "sawflies," the ovipositors of the ichneumons, the stings of wasps and bees, the eyes of all, it would be long ere all the wonders are exhausted which the microscope would reveal in the minute anatomy of these four-winged flies. 


\section{CHAPTER XII.}

\section{TW O-W I N G ED F L I E S.}

Two-winged Flies, or Diptera, as they are called by entomologists, are exceedingly numerous. There are said to be not less than ten thousand species in Europe distributed through six hundred and eighty genera, but in this country their study is exceedingly limited, yet the number must be very large. Their habits are very variable. The greater number act as scavengers in the water and on the land, and thus become sanitary agents. They are the earliest to appear in spring, and the latest to depart in autumn. Active at all times, by night and by day, in rain or in sunshine, most of them prefer the latter. This book has no pretension to being a guide to species, or the task here would be a formidable one, and therefore we shall rest content with brief allusions to some of the most important groups. Of these the Gnat family need not detain us; for although some of them fly in woods, they are more associated with the ponds and ditches in which the larvæ are reared. The twowinged gall-flies are termed Cecidomyida, and these on the contrary are addicted to vegetation of all 
kinds, whether in gardens, woods, or cultivated fields, where they inflict considerable injury. They are mostly very small, and are sometimes called "Midges," indeed many of them are quite microscopic; such as the wheat-midges, so destructive to wheat. These insects are usually studied in association with the galls, distortions, and deformations of the plants which they inhabit. They are in themselves so tiny and delicate, and so difficult to preserve, that it is fortunate for the entomologist that he obtains so much assistance in the prosecution of his studies from the malformation of the foster-plants. The larvæ live in preference on living plants, nevertheless some species have occurred in rotten wood, and some dwell beneath the bark of trees, or in the cones of firs. Most of the larva confine themselves to one species of plant, whilst some inhabit the galls of other species as parasites. Those found under the bark of trees live for the most part in company with other larvæ. It is probable that the little orange-larvæ which are found so commonly living on the orange Uredinous fungi belong to this group. These little creatures, which resemble small maggots, will be seen crawling over the under surface of the leaves of coltsfoot, when it is infested with its habitual orange rust. All the larvæ have fourteen joints, which is an apparent exception from all other larvæ, which as a general rule have thirteen.

Every part of a plant, from the root to the flower and fruit, is subject to their attacks, but each species usually attacks the same part of the plant, and deforms it in the same way. These deformations are 
very numerous; at one extreme of the series is the true gall, a growth of constant and definite form, attached to the plant by a very small portion of its surface, and at the other extreme a simple deformation, as for instance the folding of a leaf, the swelling of the veins of a leaf, or the arrest of the growth of a bud or a stalk. Several attempts have been made to classify the insects according to the nature and shape of these malformations.

The injury which these minute insects inflict is out of all proportion to their size. One little fly not a line in length, and with a larva scarce half the size of a caraway-seed, attacks the twigs of osier willows, ${ }^{1}$ and perforate them to such an extent as to render them wholly unfit for basket-making. The little flies when on the wing swarm about the low boggy places where osiers are cultivated. It is very customary for country people to call all the little two-winged fies "midges," which congregate in flocks, but these are much more commonly Ephemera.

Another of the "midges" attacks the larger willows, and this is a little larger than the preceding species. $^{2}$ The bark flakes off, or is bored so as to be easily removed, and then the surface of the rood is found to be burrowed into a number of elongated cells, in each of which a minute orange maggot will be found. This little pest is scarcely so large as a caraway-seed, which it resembles in shape, being entirely destitute of legs. From this condition it passes into the pupa stage. When ready to emerge as a perfect

- Cecidonyia viminalis.

${ }^{2}$ Cecidomyia saliciperda. 
insect, these pupæ thrust themselves halfway out of the circular hole in which they have been resident, and even after the insects have escaped, the empty cases may be seen protruding from the holes in the bark and wood. The fly is something like a small gnat, with a dark grey body, terminated, in the case of the female, by a long borer, which enables the insect to introduce its eggs in the crevices of bark.

A similar midge has been known to attack poplars, but those already named will be sufficient illustrations of a numerous group of destructive little insects.

Daddy Long-legs and Old Father Long-legs are the trivial names given to the large gnats, which in autumn are swarming in our pasture-lands, fields, and pleasure-grounds, and in some gardens bordering on low lands they are frequently abundant. In the United States it is the spider-like creature called Harvestman which is called Daddy Long-legs. Familiar as every child is with Daddy Long-legs, its transformations and history are but imperfectly known, and even cultivators seldom suspect that the surface grubs, or Leather Jackets, as the dirty-looking larva are called which do so much mischief in marketgardens, are the offspring of our old and familiar acyuaintance. It is impossible to glance along palings, rails, and even on tree-trunks near parks and grassy 1)laces, in September or early in October, without observing these gnats, especially in the morning, with legs extended and wings half-spread, under the shade of thorns and trees, five-sixths of these insects being females. Even later in chill and frosty mornings they are often abundant, hanging by their fore-feet, cheer- 
less and stupefied with cold, their wings covered with dew, and lying closed on their backs. As the day advances they become reanimated, and at every step through the grass multitudes of these flies rise, dragging their long legs after them. The females not unfrequently lay as many as three hundred eggs. The grubs often become as much as an inch in length, and as thick as a small goose-quill, of a dirty earthcolour. It was the opinion of Réaumur that they fed upon earth, but they really feed upon the roots of soft herbaceous plants, frequently causing considerable mischief in gardens. There are many species of these flies, but one of the most common is Tipula oleracea.

There are also other Dipterous flies which feed very largely upon decaying fungi, and these are classed together under a name which means "fungilovers." They do not possess any particular features which would be easily recognized by the unscientific, nevertheless they are very numerous in woodland districts, where the fungi which furnish them with their natural food abound. The larvæ of one of these flies live in society, and move in files in a soldierlike manner. First goes one, next follow two, then three, \&c., so as to present a singular appearance. In Germany it is said that the people regard these grubs with dread, because they consider them ominous of war.

A plague of flies means much more in warmer climates than in our own. So numerous are they in the East that a custom is said to prevail of passing wine and other liquors through a strainer, so that no 
flies can pass into the cup. The passage which is usually read as "strain at a gnat and swallow a camel" is said to refer to this custom, the correct reading of which would be, "Strain out a gnat." To this rendering Biblical critics have offered no objection, since it is conformable to the sense of the passage.

Flies, so called distinctively, are termed by entomologists Muscida, of which the most popular types are the House-fly and the Blow-fly. Although these are regarded as household companions, there are many similar flies to be observed, "far from the busy haunts of men," which belong to the same family. These are most annoying insects when occurring in great numbers, and yet flies as well as beetles have had their portion of human worship. In Purchas's "Pilgrims" it is said that "at Accaron was worshipped Baalzebub, that is, the Lord of Flies, either of contempt of his idolatric, so called, or rather of the multitude of flies which attended the multitude of his sacrifices, when, from the sacrifices at the Temple of Jerusalem, as some say, they were wholly free; or for that hee was their Larder-god, to drive away flies, or for that from a forme of a flie in which he was worshipped." Josephus has a rendering of 2 Kings i. 2, which seems to be an allusion to this worship: "Now it happened that Ahaziah, as he was coming down from the top of his house, fell down from it, and in his sickness sent to the Fly (Baalzebub), which was the god of Ekron, for that was his god's name, to inquire about his recovery." It has been conjectured that the fly under which 
Baalzebub was represented was the Dung Beetle, or Scarabeus, already referred to.

Many instances are on record of flies making their appearance in immense numbers, and also of the popular belief that their coming was a presage of evil. "In the summer of 1834 , which season was remarkable in England for its swarms and shoals of insects, the air was constantly filled," says a writer in the "Mirror," "with millions of small, delicate flies; and the sea, in many places, particularly on the Norfolk coasts, was perfectly blackened by the amazing shoals. The length of these masses was not ascertained, but they were, it is asserted, at least a league broad."

There is a much older record of a similar occurrence given by Southey:- "In I699, at Kerton, in Lincolnshire, the sky seemed to darken north-westward at a little distance from the town, as though it had been a shower of hailstones or snow ; but when it came near the town it appeared to be a prodigious swarm of flies, which went with such a force toward the south-east, that persons were forced to turn their backs of them."

Amongst the games and plays of the ancient Greeks was one called the Brazen Fly, a kind of Blind Man's Buff, in which a boy, having his eyes bound with a fillet, went groping round, calling out, "I am seeking the Brazen Fly." His companions replied, "You may seek, but you will not find it," at the same time striking him with cords made of the inner bark of the papyrus, and thus they proceeded till one of them was taken. 
The superstitions associated with flies are now very much things of the past, yet a few of them still linger in rural districts, such as - when flies bite more pertinaciously than usual, it forebodes rain or wet weather. If flies die in great numbers in a house, it is a sure sign of death to some of the family. To drean of flies denotes enemies of all sorts. If a fly falls into a glass from which one is about to drink, it is a sure omen of good luck.

Many people speak of the House-fly and the Gnat as if there were but two species of these insects common to our habitations, whereas, as an excellent naturalist observes, there are at least fifty, perhaps a hundred, different sorts of gnats and flies which annually visit our apartments ; that is, regular domestics, for, if casual visitors be included, the numbers would be quadrupled.

The economy of all the flies of the House-fly type is very similar: they lay eggs in dunghills, amongst putrefying vegetables, and in other places, from which are hatched minute maggots of a yellowish-white colour, and these feed and grow until they attain maturity. When full-fed the larvæ lie dormant a few hours, during which time the skin hardens until it becomes a horny case, darkening to a chestnut brown, and within this transformation to the perfect insect takes place. At length the fly creeps out of its case by means of a lid-covered opening at one end, and is then as large as at any subsequent period of its existence. The abdomen is often larger than afterwards, for it is distended with fluid, which ultimately is discharged. When the fly 
issues forth, the wings alone have to grow. These two little crumpled-up objects lie on each side of the body, as the newly-escaped fly crawls up a straw or a stick, where the wrinkles expand, and the wings at length take their proper form, covered with a delicate iridescent membrane; and when this is dried in the air, the fly is ready to take its first flight. The popular notion that the small flies which abound, in company with the larger ones, are the young of the same species, is of course an error.

One of the most noteworthy of two-winged flies is a representative of a group of some sixteen species found in this country, some of which have a buzzing flight, and a form and colouring not unlike that of the hive-bee. The most common is an insect which may often be seen hovering about thistle-heads, and the flowers of dandelion and other composite plants. ${ }^{1}$ The larvæ are aquatic, and are very peculiar, from their long flexible tails. The change into a pupa stage takes place out of the water, in which state they may be found in crevices with the tail still adhering. There is nothing very extraordinary in the appearance of the mature insect, and only an entomologist would appreciate a full description of it. The males frequently hover in the air, vibrating their strong wings with a rapidity which renders them invisible; and the body of the insect appears to be immovable and suspended in the air until it darts off in pursuit of a female, and not unusually returns to the same spot. 


\section{CHAPTER XIII.}

PLANT BUGS, APHIDES, AND SCALE.

SHOULd any of our readers cherish a favourite rose in his garden or greenhouse, he will be well enough acquainted with the "green-fly." Not that this insect, or its congeners, is confined to roses, but if one kind of them should be known, it will be easy to recognize others. The most prolific, and in some points extraordinary, of all the insect tribe are the Aphides, or "green flies." When they are seen at all, it is in very large numbers, and we pity the poorest observer of nature who has not seen them. Little, juicy-looking insects, not larger than the head of a pin, often green, with long, thin, wiry legs, clustering about the young and juicy parts of growing plants. Some call them "blight," gardeners know them as "green-fly," and entomologists as aphides, or "plant lice."

They usually show a preference to the sunny side of a wood, writes Mr. Buckton, rather than to its northern or eastern aspects. A secluded valley, a ravine with its brook of water, a light thicket on a hanging hill, or the warm side of a hillock, with its rank herbage, may be advantageously sought as being the favourite haunts of these insects. The number 
of species inhabiting a district is found to be governed, as might be supposed, by the varied character of its flora. Some aphides affect timber-trees exclusively, others feed on soft, succulent vegetables and low herbs; others again infest the roots of grasses, or hide under stones and the rotten mortar of old walls, \&c.

Although certain trees, as the lime, \&c., appear to be attacked exclusively by their particular aphis, other trees give shelter indiscriminately to numerous species. Thus, the oak is infested by at least six, the birch and willow by eight, the elm by four, the fir tribe by eight, and the currant bush by three different species.

In times past much has been conjectured and written about "honeydew," a sweet secretion, which is found in summer freely sprinkled over the upper surface of the leaves of various trees, notably of the lime and the sycamore. Some held it to be an exudation from the plant, others as a secretion exuded by aphides, and, more ancient still, that it was nectar distilled from the skies. It is now generally conceded that the honeydew as found upon leaves is derived from these insects, which is strengthened by the following memorandum from the note-book of an observer :"Bright, sunny morning; the under-sides of the oaktrees well tenanted by winged and apterous females of an oak aphis. The upper surfaces of the leaves of the Portugal laurels, growing under the oaks, are freely sprinkled with shining spots of honeydew. On gently touching one of the winged females, the abdomen was raised, and a bright particle, easily seen in the sunshine, was projected from the summit of one 
of the short cornicles. The garden seats on the open lawn are also sprinkled with the same spots."

That the aphides also cause transformations and distortions of parts of plants, resembling galls, sometimes termed pseudo-galls, will be shown when we come to write of gails and gall insects.

A casual observation of a colony of these insects will prove that they are not all alike, some being winged and others not; more minute investigation will reveal other and less evident differences.

The males are either winged, or without wings, the former being the most common. In this sex the abdomen is smaller, and the colour usually brighter. The females are also winged, or wingless in some allied genera, but in the true aphides those females which deposit eggs are uniformly without wings. Late in the season winged females bring forth their young alive, as well as some without wings. Hence we have wingless males and winged males, wingless oviparous females and, late in the year, both winged and wingless females, which bring forth their young alive.

The multiplication of aphides is enormous; some species probably are confined to one brood, while others reach to twenty, or, it is stated, to as many as ninety. Latreille says one female during summer will produce young at the rate of about twenty-five a day. Réaumur calculates that one aphis may be the mother of the enormous number of $5,904,900,000$ individuals during the month or six weeks of her existence. Professor Huxley has made a calculation which affords an approximate idea of what these immense numbers mean. Assuming that an aphis weighs as little as one- 
thousandth part of a grain, and that it requires a man to be very stout to weigh more than two million grains, he shows that the tenth brood of aphides alone, without adding the products of all the generations which precede the tenth, if all the members survive the perils to which they are exposed, contains more ponderable substance than five hundred millions of stout men; that is, more than the whole population of China. Enormous as this calculation may seem, it is clearly below the mark, for subsequent calculations, based on ascertained facts given in Buckton's "Monograph of Aphides," throws the one above given into the shade.

If this reproductive power really exist, then it will be asked, how is it that the world is not all aphides? This may be as readily accounted for in the fact that the persistent destruction almost keeps pace with their production. Ladybirds, both in their larval and mature condition, devour myriads of plantlice. For this purpose they swarm around the hopgardens of Kent and Sussex. The larvæ of these little beetles are voracious enemies of the "Hop-fly" and its kindred. This, however, is but one out of many foes. Take, as an example, the aphis which attacks wheat-ears, when in the pupa state it is attacked by a small black fly called Ephedrus, which deposits an egg in its interior. This egg soon develops a small maggot, which flourishes within, and at the expense of the aphis. Later in the season another small fly visits the wheat, and deposits its egg within the already infected pupa. This egg in the course of time is hatched, and now preys upon the 
maggot of the Ephedrus, so that not only is the young aphis destroyed, but its destroyer also meets with its. retribution, for in turn it becomes the prey of Ceraphron. The aphis is a parasite upon the wheat, the Ephedrus a parasite on the aphis, and the Ceraphron a parasite on the Ephedrus. Parasite destroys parasite, and the wheat is freed. By such means the otherwise overwhelming numbers of the plant-lice are kept in check.

Some of the most pernicious of insect pests are to be found amongst this fraternity. 'Foremost of all in the excitement and panic it has created is the Phylloxera, which has attacked the vines on the Continent, and even made its appearance in England. We have long suffered in our hop-gardens from the devastations of the Hop-fly. The white, woolly substance so common on apple-trees, and known as "American blight," is another of these insects. So, also, is a similar appearance which may be observed on larch. We are not deficient in the number of those which cause direct injury, but can recognize none which confer direct benefits, or at least any benefits which we can appreciate.

As an instance of the injurious effects of the "fly" in hop-gardens, it has been stated that in the year 1802 the excise duty on hops, which in the previous year was $\delta_{100,000}$, fell to $\mathcal{E}_{\mathrm{I}}, 000$, and that the deterioration in value was entirely ascribed to the ravages of the "fly."

Passing from these minute insects, we have another group known as Plant Bugs, of a much larger size, but not capable of inflicting such widespread injury. 
We have seen these insects in woods and forests on the Continent in much larger numbers than in our own islands; except, indeed, some aquatic species, they would seem to be rather rare with us. The Hemipterous insects, as they are termed, have four wings, two of which form hard coverings, with membranous ends, and the mouth-organs are formed of bristles, which compose a sucker, inclosed in an articulated sheath, forming a projecting beak.

These might appropriately be called sucking insects; and those who divide and group them for scientific purposes, recognise the Bugs-viz., House Bugs, Tree Bugs, and Water Bugs-as one family; the noisy Cicadas, or Harvest-flies, as another ; then the Frog-hoppers, the Plant Lice (Aphides), and Scale insects, as other families. Tree Bugs, or rather Plant Bugs, for they are not confined to trees, are insects of a retiring habit ; hence they are seldom seen except when sought after. They are often very angularly-shaped insects, and, as we should say of individuals, broad in the shoulders, so that it is often easy to recognize a plant bug at a glance. Sometimes a number will congregate together in the cracks of the bark of trees, and may be easily caught; others must be sought in flowers. The majority of species are predacious, feeding upon other insects, sucking out their juices; but some few perform the same operation on plants.

Any one who has taken up a United States journal, even of a popular science character, will have observed that many insects are called "Bugs" which have no right or title to the name. Thus 
the Colorado Beetle was, and perhaps still is, called the Potato Bug; and others which are in reality beetles are degraded into bugs. This would be of very little importance to those who know and recognize the value of the scientific names; but it serves to illustrate the fact that the use of popular names alone will be found of but little service to those who desire to step over the threshold which separates popular knowledge (or popular ignorance) from practical knowledge.

The common Froth-fly (Tettigonia spumaria) may be seen in spring in small patches of white, frothy matter on the young shoots of herbaceous plants. This froth is termed Cuckoo Spittle by country people, from its being conspicuous about the time when the cuckoo arrives in this country. On removing the froth, one or two small green larve will be found concealed in the midst, which are able to skip away when disturbed. About the middle of June they become pupæ. When the perfect insect escapes, it leaves amongst the froth a transparent, horny case attached to the stem by its feet. Formerly they were called Cicadas, but they are not true Cicadas. The perfect insect is of a dirty yellowish-white, thickly clothed with short hairs. The head is triangular and broad, with an eye on each side at the base, and two small ones on the crown. The face has a black stripe down the centre, with several horizontal lines, radiating on each side like a comb. The wing-covers are brown, more or less mottled with olive, with four large whitish patches on the margin; the wings are transparent 
and iridescent. There is, however, considerable variation in the colour and markings of the perfect insects, and they may be seen, resting upon flowers, as late as September and October. These, too, have their enemies, which aid in keeping their numbers in check, for a species of Sand Wasp ${ }^{1}$ has been seen carrying away the pupæ into its cells in neighbouring banks, in order to feed its young. ${ }^{2}$

Scale insects, sometimes called Bark Lice, are very troublesome in hothouses, where they attach thenselves to exotic plants; but there are other species than these, and as common in woods and hedges. The females may be seen adhering to the bark of pear and apple-trees in gardens, to the sloe in hedgerows, and to the beech and other trees in woods. These females are gregarious in considerable numbers, and resemble miniature mussel and oyster shells, which adhere firmly to the bark. Remove one of these scales with the point of a penknife, and beneath the hollow shell and shrivelled remains of the old insect a cluster of eggs will probably be found, waiting their time to reproduce the species. The males are winged, and thus afford a singular contrast to the females. These are important insects commercially, although the native species are regarded as pests. One species furnishes the wellknown cochineal dye, and is a native of Mexico, where it feeds upon a cactus. Another, common in India on the twigs of various trees, secretes a

1 Gorytes campestris.

2 “Gardener's Chronicle," p. 508. I $8_{42}$. 
resinous substance which also contains a colouring matter known as lac-dye, and the resinous portion, being melted down after the colour is extracted, is shell-lac, or seed-lac, according to the manner in which it is prepared. Yet another species was found in the neighbourhood of Mount Sinai feeding on the tamarisk, on which it produced a sweet secretion resembling manna. And in China a beautiful white wax is due to insects of this family. If the oranges which are imported into this country are carefully examined, a few female caci will often be found adhering to the rind; and any gardener will furnish specimens of a "scale" which persistently adheres to the fronds of cultivated palms and other plants.,

If a gardener be asked his experience of these insects in hothouse cultivation, he will furnish plenty of material for judgment on their capacity for mischief in what he may have to tell of the Mealy Bug, and the Pineapple Scale, and the Orange Scale, and unfortunately many others. Some of the herbaceous plants in lanes and woods are often densely covered about the stems with little scale insects; but they so little resemble insects in appearance, that they are liable to be mistaken for some unhealthy condition of the plant.

There are two ways in which these and all other insects may be made objects of study. The one and most common method, is to collect the insects wherever they can be found, kill them, and expand and arrange their wings and legs, attach to them the names by which they are scientifically known, and arrange them in boxes, in an orderly manner, 
in accordance with their relationship, the one with the other. There is another method which limits the student to a few species; these he seeks to comprehend as individuals, to trace their life-history, their modes of existence, transformations, and, above all, their entire structure. The microscope, of course, is fully employed in such researches; and, as may be expected, this is the method which will best satisfy those who seek to become acquainted with the mysteries of life as exhibited in the minute creatures which abound everywhere, - to comprehend

"How He who makes and peoples worlds still works In secrecy, behind a veil of light;

Yet through that hiding of his power, such glimpses

Of glory break as strike presumption blind,

But humble and exalt the humbled soul,

Whose faith the things invisible discerns, And God informing, guiding, ruling all." 


\section{CHAPTER XIV.}

\section{DRAGON-FLIES AND OTHER INSECTS.}

Most dwellers in towns have had some experience of the disagreeable process of "removing." Such being the case, they will understand what we mean when we allude to the "last load," as a heterogeneous medley coming from all parts of the old house, defying classification, and more troublesome in their disposal than all the rest. With this chapter we are almost in the same position as the householder with the last load. We have a miscellaneous collection of insects, none of them of very great importance or interest, belonging to different orders, and without any other excuse for coming together than that which prevails in the "last load."

Foremost amongst these is the Earwig (Forficula auricularia), an old acquaintance in gardens, but as common in woods and many places beside. It is not every one who is aware that earvigs can fly; but they have wings amply sufficient for this purpose, and when at rest these are folded and hidden so as not to be suspected. These insects belong to the Orthoptera, which have all delicate wings, and are 
nocturnal in their habits. The female earwig broods over her eggs after the manner of a hen. De Geer, having found an earwig so occupied, placed her in a box with some earth, scattering her eggs in all directions; these she soon collected in a heap, and then sat upon them as before. When the young are hatched, they creep, like a brood of chickens, under the belly of the mother, who suffers them to push between her feet, and will often, as De Geer found, sit over them in this posture for hours.

The Cockroach (often called the Black Beetle) and the Cricket are both members of this same order; and so also are the Mole Cricket, Field Cricket, Grasshopper, and Locust. Fortunately, the latter causes us very little inconvenience in our island home, but in the Orient it is very destructive. Stick insects and leaf insects, so called from their resemblance to sticks and leaves, and the Praying Mantis, all belong to this order.

It is doubtful, even if locusts were common with us, if we should revenge ourselves upon them exactly in the same way as Jackson relates of them in Barbary, where he says, that dishes of locusts were generally served up at the principal tables, and esteemed a great delicacy. "They are," he says, "preferred by the Moors to pigeons, and a person may eat a plateful of two or three hundred without feeling any ill-effects." To what extent cockroaches are eaten by the Turkish ladies we cannot affirm, but they are said to promote obesity, one attribute of beauty.

That crickets and grasshoppers when in con- 
finement will eat raw meat, and even harder substances, approaching to leather, if not leather itself, has been demonstrated. This becomes less surprising when a knowledge of their minute anatomy is obtained; for they possess gizzards furnished with an elaborate arrangement of gastric teeth, as most microscopists are aware, the gizzard of a cricket being quite a "stock object."

Jaeger says that the youth of Germany are extremely fond of field crickets, so much so, that there is scarcely a boy to be seen who has not several small boxes made expressly for keeping these insects in. So much delighted are they, too, with their music, that they carry these boxes of crickets into their bedrooms at night, and are soothed to sleep with their chirping lullaby.

Minute Neuropterous insects which might be mistaken for aphides are not uncommon. These are called the Psocida. In all their states they probably feed on dry vegetable substances and lichens. They are universally common, living more or less in societies on tree trunks and palings and amongst the herbage of trees, especially firs, larches, and yews; and some species in houses and warehouses. The eggs are laid in patches on leaves, bark, or other objects, and the females cover them with a web. Mr. McLachlan believes that both sexes possess the power of spinning a web, not distinguishable from that of spiders. The larvæ and pupæ greatly resemble the perfect insects. One of these little insects which is found running over books and collections of preserved insects in cabinets, has been supposed to be one of the "death watches," 
about which superstition has much to relate. Entomologists generally do not believe that the little Atropos divinatorius, with its soft body, is capable of producing the ticking sounds which have been attributed to it. Whoever has the misfortune to possess a large herbarium of dried plants will soon become conscious of the presence of little soft-bodied insects, not much

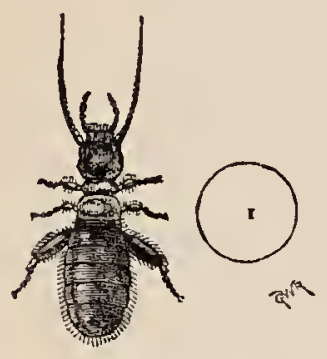

ATROPOS.

larger than mites, but members of this family, which are very liable to make themselves at home in such places.

The Day-flies ${ }^{2}$ or May-flies appear in swarms in the neighbourhood of rivers, and sometimes these swarms are so large that they inspire dread in country districts. Réaumur once saw them descend so fast that the step on which he stood by the river's bank was covered by a thick layer in a few minutes. He compares their falling to that of snow with the largest flakes. Being aquatic in their habits, they are only alluded to in passing.

The Aphis lion is one of the names which have been applied to the larvæ of what is also termed the Lace-wing fly, ${ }^{2}$ one of a group of Neuropterous insects with small slender bodies, four large transparent net-like wings, and prominent golden eyes. The wings have a greenish tint and reflect delicate prismatic colours. The insects fly in the twilight, remaining

1 Ephemera.

2 Hemerobius perla. 
inactive during the day, and when touched emit an offensive odour. The females deposit their eggs upon plants, especially those infested with aphides, attaching them at the ends of long, slender, rigid footstalks, the base of which is attached to the leaf. These stalked eggs have somewhat the appearance of minute fungi, and it is a fact that an excellent mycologist once described and figured them as the type of a new genus of microscopic fungi. The larvæ which are produced from these eggs are the ant-lions, which Professor Westwood has graphically described. In the month of May, he says, a singular-looking object may be occasionally seen walking over plants, having very little of the appearance of an insect, resembling rather a moving mass of cottony or other materials : on carefully examining the mass with a magnifying glass, we perceive a head furnished with two long and slender curved jaws, followed by three pairs of legs protruded from the mass, which being removed we find an active fleshy larva, something like that of the ladybird, covered with scattered hairs. This larva feeds upon aphides, and is extremely voracious, seizing them with its jaws and sucking their juices. These jaws are moreover used by the insects for the further purpose of forming the covering which it carries upon its back, and which often consists of the skins of the dead bodies of its victims. When full grown this larva spins a cocoon, within which it is transformed into a pupa. In this state it often remains through the winter. There are several of these aphis-lions, differing from each other somewhat in form.

During a woodland ramble in summer-time one is 
certain to encounter the great Dragon-fly restlessly darting about the avenues. Yet, from their associations, we should rather be disposed to regard them as insects belonging to rivers and marshes. Their larvæ are aquatic, but the mature insects may be seen skimming about almost everywhere. Dr. Packard says: "Were we to select from among the insects a type of all that is savage, relentless, and bloodthirsty, the Dragon-fly would be our choice. From the moment of its birth until its death, nearly a twelvemonth, it riots in bloodshed and carnage. Living beneath the waters perhaps eleven months of its life, in the larva and pupa states, it is literally a walking pitfall for luckless aquatic insects; but when transformed into a fly, ever on the wing in pursuit of its prey, it throws off all concealment, and reveals the more unblushingly its rapacious character. Not only does its horrid visage and ferocious bearing frighten children, who call it the Devil's darning-needle, but it even distresses older persons, so that its name has become a by-word. Could we understand the language of insects, what tales of horror would be revealed! What traditions, sagas, fables, and myths must adorn the annals of animal life regarding this dragon amongst insects."

The Springtails are little insects generally found on the ground in damp places, under stones, old bark, rotten wood, and dead leaves. Some kinds frequent damp cellars and dark cupboards. On being disturbed, most species skip off like fleas to a great distance, by means of a forked apparatus which is pressed under and close to the belly. By striking this 
out backwards with considerable force, the insect is thrown forwards with a spring. Dark lead-coloured infividuals of this group may be sometimes seen in immense numbers in roadside puddles, or by the margin of ponds, like grains of gunpowder. Other species are found but few together and almost solitary. Some controversy has of late years been carried on as to the true interpretation of the marking on the scales with which many of the species are furnished, and in these communications they are spoken of as Podura scales, although that general term includes two or three different genera. It is sufficient for our purpose to call them Podurida. They appear to be very partial to mites as food.

The "world of insects" is not a mere phrase, it is a reality, of which we have taken but the poorest glimpse. To know all the inhabitants of this world, even by name, is the work of a lifetime, but what of their structure, their economy, their loves, their lives, their instincts? These are mysteries of which we have as yet learnt but little, compared with what remains to be known. If any man be vain of his knowledge, thinking himself wise, let him but visit the "world of insects," and question himself which is the greatest, his knowledge or his ignorance. 


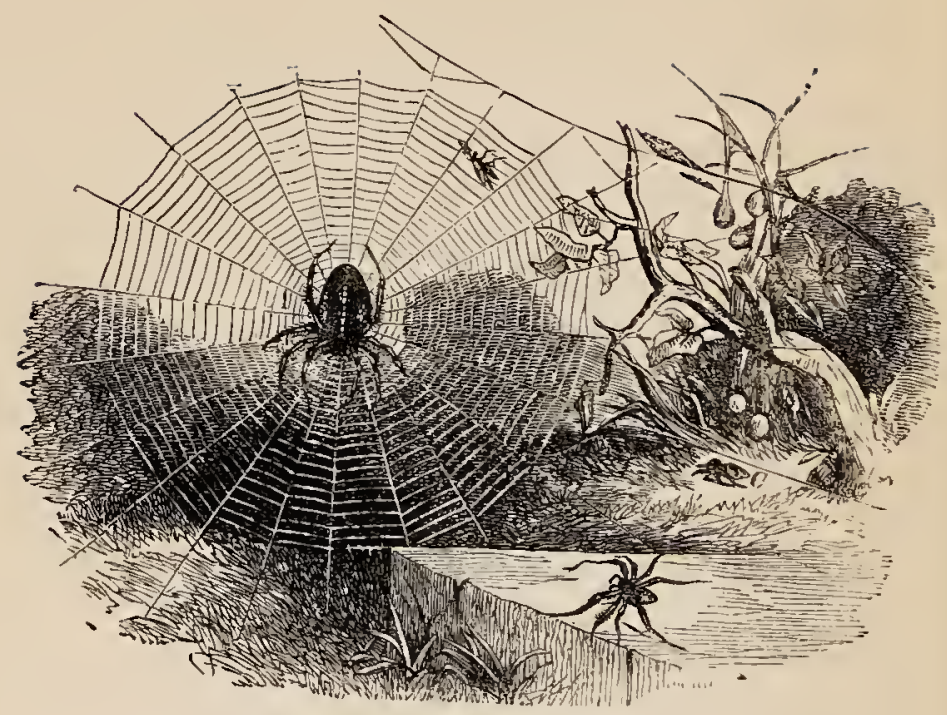

\section{CHAPTER XV.}

SPIDERS.

As we look from our windows at the shrubs outside during the autumn, it is a very common occurrence to see two or three large geometric spiders' webs constructed from branch to branch. A large, full-bodied, plump spider is in the centre, motionless, and ready for business. He remains there with his head downwards, and if we approach, it is evident that on the back of his plump carcase there is a distinct white cross. This is one of our finest, as it is one of our commonest species, and it is not confined either to gardens or conservatories, but will be seen also in woods and forests. 
He will serve as a good introduction for us to the Spider tribe, and the Diadem Spider ${ }^{1}$ may be taken as a type of spiders.

At one time spiders were included with insects in the same class, and so now many people speak of them as insects, but they are more nearly allied to the crustacea, or crabs and lobsters, than to butterflies and beetles. They have, as a rule, four pairs of legs, and in this respect the minute Acari or mites agree with them, and are included in the same class.

Some persons have a great dislike to spiders, and it is said that both Turenne and Gustavus Adolphus, notwithstanding their general courage, would shudder at the sight of these little creatures. They have their place in history from the time of Domitian to that of Robert Bruce. The story of the latter is too well known to need repetition, and a similar anecdote is related of Mahomet, that when himself and a companion were fleeing from their enemies, they hid for three days in a cave, over the mouth of which a spider spread its web, and a pigeon laid two eggs there, the sight of which made their pursuers pass on, and not enter in search of them.

When Pelisson was confined in the Bastile in company with a Basque, who played on the bagpipe, a spider was accustomed to make its appearance at the window on hearing the music, and on these occasions was fed by the prisoners, so that it became a regular visitor to solace their captivity. The governor of the Bastile, it is added, hearing: 
that the unfortunate prisoner had found a solace in the society of a spider, paid Pelisson a visit, desiring to see the manœuvres of the little creature. The Basque struck up his music, the spider instantly came to be fed by his friend, but the moment it appeared on the floor of the cell the governor placed his foot on its body, and crushed it to death.

When Lauzun was captive, lie was consoled by the visits of a friendly spider; but a still more interesting narrative of Quatremer Disjonval, and how he obtained his release from prison, through watching spiders, is recorded in the Quarterly Revieze (January, I 844). Hereafter let no one shudder at the presence of a spider.

One of the things not generally known is the peculiarity in the eyes of spiders. In the majority of species they have eight eyes, in some only six, and in a very few only two. The eight eyes are placed in different positions relatively in different genera of spiders; in insects the eyes are generally compound, but in the Spider all the eyes are simple.

When spiders are about to deposit their eggs they usually spin silken cocoons for them, which are placed in various situations. Many species abandon their cocoons as soon as they are completed; others show the greatest attachment to them, and watch them with solicitude, and some carry them about with them wherever they go. Before the young spiders reach maturity, they moult several times. One species has been known to moult five times, another nine times. Mutilated limbs are reproduced at the time of changing the integument, or moulting. It is uncertain to 
what age spiders will attain; some have been known to live four years.

"Under the guidance of their respective instincts," says Mr. Blackwell, "a high degree of skill and industry is displayed in the construction of their retreats. Many species occupy holes formed by themselves beneath the surface of the earth, some of which, of a cylindrical shape, are lined with a compact tissue of silk, and have the entrance closed by a valve, provided with a hinge, which can be opened and shut at pleasure. Other species fabricate in the crevices of walls, the crannies of rocks, beneath stones, on the leaves of vegetables, and under the exfoliating bark of trees, - tubes, cells, or domes of silk, on whose exterior surface-soil minute pebbles and other heterogeneous materials are frequently distributed. A Theridion fabricates a slender conical tube of silk, of a very slight texture, measuring from one and a half to two and a half inches in length, and about half an inch in diameter at its lower extremity. It is closed above, open below, thickly covered externally with bits of indurated earth, small stones, and withered leaves and flowers, which are incorporated with it, and is suspended perpendicularly by lines attached to its sides and apex, in the irregular snare constructed by this species. In the upper part of this singular domicile the female spins several globular cocoons of yellowishwhite silk, of a slight texture, whose mean diameter is about one-eighth of an inch, in each of which she deposits from twenty to sixty small spherical eggs, of a pale yellowish-white colour, not agglutinated together. The young remain with the mother for a 
long period after quitting the cocoons, and are provided by her with food, which consists chiefly of ants."

This little spider called Theridion riparium is not more than one-seventh of an inch in length, and is found about banks in woods, its domicile being formed in August. Two other allied but more common species are found in the same localities. One of these incloses its cocoon in a tissue of white silk on the under surface of leaves of trees and shrubs; ${ }^{1}$ the margins of the leaves are drawn in around the nidus, and held in that position by silken lines. The other constructs a cocoon of dull green silk amongst foliage, and placed beneath a dome-shaped canopy of silk, around which withered leaves are accumulated. In both these instances the young continue to live with their mother until they are old enough to take care of themselves. The web, or snare, of the species in this genus consists of crossed lines, which intersect each other at various angles, and without any apparent regular plan.

Returning again to the Diadem Spider, ${ }^{2}$ with which we started, we have a great contrast to the Theridion last named in the regular geometrical webs which all the species of Epeira construct. Radiating lines are united by a spiral thread, thickly studded with minute globules of liquid gum; but the central convolutions. are devoid of globules, so that its owner may rest there and watch for prey without being incommoded by its own snare. It has been stated that all these 
species of Epeira place themselves in the centre of their net, with their heads directed downwards.

The Melon Spider ${ }^{1}$ is not more than a quarter of an inch in length, and its conspicuous oval abdomen is of a melon-green colour, with a red spot at the outer extremity. Its geometrical net is often horizontal, but sometimes inclined, attached to shrubs, to which also its cocoon, of bright yellow silk, is affixed. Another, ${ }^{2}$ even more common, species constructs a geometrical net in woods, with a vacant space in the centre, which it usually occupies. Whenever disturbed, it drops suddenly, as if falling to the ground, but really remains suspended by a thread, along which it regains its position in the centre of its snare when all danger is past. Most of the species in this group have the abdomen beautifully variegated with white and black spots and lines.

Mr. Blackwell has calculated the number of viscid globules which would be distributed over a geometric web of a medium size. He says that "The mean distance between two adjacent radii is about seven-tenths of an inch: if, therefore, the number seven be multiplied by 20 , the mean number of globules which occur on one-tenth of an inch of the elastic spiral line at the ordinary degree of tension, the product will be 140 , the mean number of globules deposited on seven-tenths of an inch of the elastic spiral line. This product multiplied by 24 , the mean number of circumvolutions described by the elastic spiral line, gives 3,360 , the mean number of globules contained between

1 Epeira cucurbitina.

2 Epcira inclinata. 
two radii, which multiplied by 26 , the mean number of radii, produces 87,360 , the total number of viscid globules in a finished net of average dimensions. A large net, fourteen or sixteen inches in diameter, will be found by a similar calculation to contain upwards of 120,000 viscid globules, and yet an Epeira will complete its snare in about forty minutes, if it meets with no interruption."

There is a family of spiders called the Linyphizda, which are allied to the family to which the Diadem Spider belongs, and which usually inhabit the branches and foliage of trees and shrubs. In general appearance the body is proportionately longer and narrower than in the Epeirida. They are rather small, often mottled, and fabricate a thin sheet of web of variable extent, on the under surface of which they take their station in an inverted position. Some of the species are rare, but there are two or three which are sufficiently common to be met with in a stroll in the woods.

"It is really remarkable," observes the Rev. J. G. Wood, "that considering the great number of species which inhabit England so very few should have been sufficiently distinguished to receive popular names. Owing in all probability to the foolish dislike towards spiders entertained by most persons, a dislike which has been instilled into their minds at a very early age, these wonderful and interesting creatures are seldom watched, and there are very few persons who really know one spider from another, or who have any idea of their exceeding usefulness when in the places which they were intended to inhabit." The 
species of Linyphia just alluded to have no popular names, as indeed is the case with nearly all the species. to which we shall have occasion to refer.

One species, not uncommon, belongs to a small group having a peculiar modification of structure to suit its condition of life. This is called Ciniflo atrox. The modification consists in each hind leg being furnished towards the extremity with two parallel rows of movable spines, which are used as a curling apparatus. The snare is composed of silky threads, some of which are elaborately curled by means of the curling-spines just alluded to. The entire length of the spider is about three-eighths of an inch, and amongst other places it is found under the bark of old trees. It is worthy of note that this spider has an additional, or fourth pair of spinners.

The hunting spiders are very pretty little creatures, rather elaborately coloured and marked, and often singular in form. One of the species is well known, at least to microscopists, and this is perhaps the most common. ${ }^{1}$ It is not more than a quarter of an inch in length, and is generally to be found hunting for insects on the trunks of trees. It is said to be a very pugnacious little marauder, capturing its prey by leaping upon it unawares, at the same time spinning a thread which is attached to the place whence it takes its spring, in order to be provided against a fall. The legs are modified for leaping, at which it is expert. Indeed this is a very Nimrod amongst the spiders. As we have seventeen or eighteen species

\section{${ }^{1}$ Salticus scenicus.}


of these hunting spiders in Britain, it should not be difficult to become acquainted with some of them. Although from their habits of life they can dispense with a snare, the female constructs a cocoon of white silk for her eggs, and this is concealed under the bark of old trees or in crevices of walls and rocks.

There is another family of spiders called Thomisida, which hunt their prey in a similar manner, but they are not so attractive in appearance. The Drassida construct for themselves little cells amongst leaves, and in these they lie in wait for their prey, leaping upon unwary insects that may pass their dens.

It is worthy of remembrance that some spiders are quite nocturnal in their habits. They do not make their appearance at all in the daytime; and hence many kinds may seldom or never be seen except by those who know where to search for them, and then only rarely. Night in the woods is not absolutely a period of quiet and repose. Birds, quadrupeds, insects, spiders, molluscs, have all their nocturnal species, and these retire to rest during the day.

The "Gossamer Spider" is a term which has been often used in a manner which would lead to the conclusion that there is one particular spider which performs the aërial flights so often alluded to or described. Whereas it is probably the young as well as the mature of several species which are concerned in these evolutions. As in most phenomena which did not receive immediate elucidation, this became entangled with a little romance.

Lister says that one day in autumn, when the air was full of wefts, he mounted to the top of the highest 
steeple of York Minster, from whence he could discern the floating webs still very high above him. Some spiders that fell and were entangled upon the pinnacle he took. They were of a kind that never enter houses, and therefore could not be supposed to take their flight from the steeple. From his observations it is clear that he did not consider this faculty to be confined to one species of spider, but common to several, though only in their half-grown state. Of one, he says, certainly this is an excellent rope-dancer, and is wonderfully delighted with darting its threads; nor is it only carried in the air, but it effects itself its ascent and sailing; for by means of its legs closely applied to each other it as it were balances itself, and promotes and directs its course no otherwise than as if nature had furnished it with wings or oars.

Mr. Blackwell gives a summary of the facts as far as they are known :- "Although spiders," he says, "are not provided with wings, and consequently are incapable of flying in the strict sense of the word, yet by the aid of their silken filaments numerous species belonging to various genera are enabled to accomplish distant journeys through the atmosphere. These aërial excursions, which appear to result from an instinctive desire to migrate, are undertaken when the weather is bright and serene, particularly in autumn, both by adult and immature individuals, and are effected in the following manner. After climbing to the summits of different objects, they raise themselves still higher by straightening the limbs; then elevating the abdomen by bringing it from the usual horizontal position into one almost perpendicular, they 
emit from the spinners a small quantity of viscid fluid, which is drawn out into fine lines by the ascending current occasioned by the rarefaction of the air contiguous to the heated ground. Against these lines the current of rarefied air impinges, till the animals, feeling themselves acted upon with sufficient force, quit their hold of the objects on which they stand and mount aloft."

Spiders do not always ascend into the atmosphere by a vertical movement, but are observed to sail through it in various directions; and the fact admits of an easy explanation when the disturbing causes by which that subtle medium is liable to be affected are taken into consideration. A direction parallel to the horizon will be given by a current of air moving in that plane; a perpendicular one by the ascent of the air rarefied; and directions intermediate between these will in general depend upon the composition of forces. When the horizontal and vertical currents are equal in force, the line of direction will describe an angle of $45^{\circ}$. nearly with the plane of the horizon; but when their forces are unequal, the angle formed with that plane will be greater or less as one current or the other predominates.

The manner in which the lines are carried out from the spinners by a current of air appears to be this. As a preparatory measure, the spinning mammula are brought into close contact, and viscid matter is emitted from the papillæ; they are then separated by a lateral motion, which extends the viscid matter into fine filaments connecting the papillæ; on these filaments the current impinges, drawing them out to a length 
which is regulated by the will of the animal, and on the mamillæ being again brought together, the filaments coalesce and form a compound line.

This author believes that spiders are unable to dart lines from their spinners, and proposes certain experiments by which this can be proved. There is one curious notion suggested by Robert Hook, one of the earliest fellows of the Royal Society, which shows to what an extent theorizing may go. Writing of these gossamer webs he says, "they were of the same weight, or very little heavier than the air, and 'tis not unlikely but that those great white clouds, that appear all the summer time may be of the same substance."

Gilbert White describes a shower of these webs which occurred in I 74I :- "About nine an appearance very unusual began to demand our attention, a shower of cobwebs falling from very elevated regions, and continuing, without any interruption, till the close of the day. These webs were not single filmy threads floating in the air in all directions, but perfect flakes of rags; some near an inch broad, and five or six long. On every side, as the observer turned his eyes, might he behold a continual succession of fresh flakes falling into his sight, and twinkling like stars."

The Times of Oct. 9, 1826 , relates a similar occurrence at Wigan:- "The fields and roads were covered with a light filmy substance, which by many persons was mistaken for cotton. In walking in the fields the shoes were completely covered with it, and its floating fibres came in contact with the face in all directions. Every tree, lamp-post, or other projecting body had arrested a portion of it. It profusely descended at 
Wigan like a sheet, and in such quantities as to affect the appearance of the atmosphere. On examination it was found to contain small flies, some of which were so diminutive as to require a magnifying glass to render them perceptible. The substance so abundant in quantity was the gossamer of the garden or field spider, often met with in fine weather in the country, and of which, according to Buffon, it would take $663,55^{2}$ spiders to produce a single pound."

A far more ancient shower is recorded by Pliny, for he says : "In the year that L. Paulus and C. Marcellus were consuls it rained wool about the castle Carissa, near to which a year after T. Annius Milo was slain."

The question of spider poison, and of the power of spiders to eject venom into the wounds which it causes, need not be entered upon in detail here. The fact is undoubted that the falces terminate in a hard, sharp, curved fang, with a slit or fissure near the point. That a secretory gland exists near its base with a channel from it to the orifice. And that a poisonous fluid can be emitted from the fang, at least a fluid which renders insensible the small insects which are wounded by it, although probably not sufficiently poisonous to incommode higher animals.

Long-legged, spider-like animals, called Harvestmen or Harvest-spiders, appear to live equally well about houses or in the most lonely forests. They seem to be most active in the early morning or evening, preferring twilight to the glare of the sun. Unlike the true spiders, they have only one pair of eyes, but their legs are extravagantly long. They are carnivorous, feeding on small insects, with a partiality for aphides. 
The spiders are content with sucking the juices of their victims, but the Harvestmen devour them bodily. When walking the body is raised but little from the ground, so that it is upon a level with its prey. They spring and pounce upon their victim as a cat upon a mouse, and hold it with their palpi as if with hands. Mr. Fulk writes: "I have repeatedly seen individuals of Phalangizum when in confinement pursue each other with the utmost pertinacity, the larger generally pouncing upon the smaller, and having brought them within reach of their palpi by grappling them with their long legs, proceed to devour the body, leaving the extremities untouched. They use one of their legs occasionally to support the food to their mouth. Towards the close of summer all the females are full of eggs. These are laid in protected crevices, under dry stones, \&c., and are hatched out in the spring." The name of Harvestmen has been given to these spiders, it is said, on account of a prevalent superstitious belief that if killed there will be a bad harvest. Be this as it may, there is certainly a prejudice in their favour amongst country people which protects them against being wantonly destroyed. In the United States they are called Daddy Long-legs.

Closely allied to the spiders are those small but almost innumerable little creatures, the Acari or Mites, such as are found in coarse sugar, old cheese, stale meal, and various other articles of domestic utility. They abound in woods, but are so minute that they cannot be distinguished except by the aid of a lens. Birds have their own particular species which is parasitic upon them. Beetles may be seen running about, 
bearing them upon their bodies. Dead leaves and decaying fungi swarm with them. The rotting bark of old stumps incloses them, and they may be seen even on the bark of living trees. Wherever there is putrefaction and decay they are sure to be found, and in many other places where there is no evidence of either. Some of them live in large colonies, weaving webs almost in the manner of spiders. Others are aquatic and float in ponds like tadpoles. Some are black as a fragment of jet, others white as snow, others again of the most vivid scarlet, crimson, or green. In their mature condition they have four pairs of legs like spiders, and, like them, they moult or change their skins before they arrive at maturity. If there are any animals which can be described as ubiquitous, they are the mites, for it would be exceedingly difficult to name bodies organic or inorganic on which they have never been found. The historian of these minute creatures would require a large volume to record their names and detail their characteristic distinctions. From us they can only receive this general allusion as we pass on to larger and more visible objects.

When a strip of bark is torn from an old stump, or from a tree trunk which has lain for a long time on the ground, a medley of animated creatures will be seen scampering off in all directions to hide themselves. Doubtless there will be myriapods, or millepedes, for that is just the kind of locality suited to their propensities, and there will be wood-lice, rolling themselves into shining balls like pills, for protection, mites, springtails, small beetles, a spider or two, and probably some cocoons of spiders' eggs. It is more 
particularly the strange creatures with a great number of legs on each side of their body, called Myriapods, or manyfooted, which must for a short time detain us. They are curious creatures, with very few friends, although comparatively harmless, some of them even being useful; it will be sufficient to notice them under three types, the Wood-lice, the Millepedes, and the Centipedes.

The Wood-lice consist of several species, and these are known locally as Sow-bugs, Old sows, Pig-lice, Carpenters, and Slaters. Some of them, as the Armadillo (Oniscus armadillo, L.), roll themselves in a ball when touched, others (as Oniscus asellues) do not habitually roll up. They are covered with horny plates like coats of mail, and have seven pairs of legs. The two species above named are found in gardens and amongst rubbish, but similar species are to be met with in woods, and sometimes the same. They walk slowly unless disturbed, when they run away fast. They shun the light and the heat of the sun, and hence are seldom to be seen during the day, unless disturbed in their hiding-places. The food of this group is undoubtedly vegetable, and they are the most destructive of all, being troublesome in gardens.

The Millepedes, or Snake Millepedes, are several kinds of Julus, from half an inch to nearly two inches in length, with rounded cylindrical bodies covered with horny plates, and about a hundred pairs of short legs. When touched or disturbed they coil themselves up spirally into a compact coil. They all walk slowly, or rather glide along in a peculiar kind of way, from the immense number of legs they possess, and which, 
when in motion, look like a fringe of hairs. Several species of them are found in England, delighting in loose bark and old stumps, feeding on decayed vegetable matter, on decomposing animal substances, and acting as a kind of scavenger. Some of them delight in Acari, but it is doubtful if any of them feed at all upon living plants. The most common species ${ }^{1}$ has from $I 60$ to 200 legs, and is from an inch to an inch and a half in length.

Still more interesting, but equally common, is at least one species of centipede, ${ }^{2}$ found under stones or fallen timber. It is from two to three inches long, and has from fifty-one to fifty-five pairs of legs. The female lays from thirty to fifty eggs in a cell in the ground, and coils herself round them, in which position she remains for two or three weeks, until the young brood is hatched. Both sexes are luminous, shining almost as brightly as the glow-worm. Whatever the luminous substance may be, it certainly adheres to the fingers like phosphorus when the animals are handled. We have several times collected in the dark, luminous creatures under the impression that they were glow-worms, and when brought to the light discovered that they were centipedes. Another small centipede $^{3}$ is common in hop-gardens, hybernating in clusters of six or eight, rolled up like a ball, but whether luminous or not we cannot affirm.

Although only partially related to our locality, we cannot forbear a parting word with the Worms. It is

1 Fulus terrestris.

'Arthronomalus longicornis. 
customary to say the common Earth-worm, but there are several which the naturalist knows how to distinguish the one from the other. Montpellier has determined thirty-five species, in Britain the number has been fixed at eleven. The late Dr. Baird gave some interesting details of the habits of worms. He says, "The Earth-worm " moves along the surface, or in the soil, by alternate elongations and contractions of a determinate portion of the body. It can move backwards or forwards with nearly equal facility, and when seized in its progress it wriggles and twists itself into many coiled knots and circles. This it does also when wounded, and its writhings surely indicate a severe degree of suffering in the poor worm, which is too often wantonly trodden upon. The movements of the earth-worm in its burrow are performed with much greater rapidity than on the surface, a superiority which results from the disposition of the bristles along the sides; for in a cir cular tube alone can they all be brought into action and made to act as fulcra, the animal having the power of protruding them to a slight extent. Hence we find that the hole of the worm is of the same figure as its body, and nearly of the same calibre; that the ascent and descent may be retarded neither by over straightness, nor by a wideness which would render the contact of the bristles against its walls impossible. The holes are in general sinuous, and worked in an oblique direction, and lined with the slimy juice which exudes from the skin. They vary 
in depth from a few inches to upwards of four feet, and have two, or occasionally several, apertures, of which one is the vent, whence they eject those vermicular pellets of earth that have passed through the intestine, and are in fact moulded and fashioned within it."

Wishing to burrow, and having selected a soft, moist earth, the worm stretches forward the anterior portion of its body and stiffens it. It now pouts out the upper lip, and rendering it, too, tense and elastic, the worm pushes it under the soil or clod, raises it and casts it aside; then again it digs and loosens another portion of the earth, until, by many repetitions and much patience, the tumnel is insensibly yet speedily completed. As the worm swallows the greater proportion of the soil raised in the progress of the work, nature has furnished it with no instruments for the removal of the obstacle, such as have been given to many other boring insects.

Their favourite residence is a recent vegetable mould heap, the under side of a flat stone in damp situations, and the earth immediately below half-dried cow-dung. It deposits its eggs in capsules at a considerable depth in the soil.

Gardeners and farmers express their detestation of worms, and yet even worms have a mission which gardeners and farmers fail to comprehend. 


\section{CHAPTER XVI.}

\section{SLUGS AND SNAILS.}

We almost despair of exciting any sympathy in the attempt to develop an interest in "Slugs and Snails." Every one has for himself arrived at the conclusion that they are nasty, slimy things, which could not possibly exhibit any redeeming feature. Prejudice is a very powerful enemy, still we are bound to ignore it in dealing with natural objects, affirming meanwhile that nothing which has been created is without fitness for the station it is designed to fill, or without use in the great economy of which it forms a part. We possess no privilege to despise the meanest thing which crawls, and undoubtedly we know least of the objects we dislike the most. We should rather distrust ourselves in regarding any living thing as beneath our notice, because, accurately interpreted, it only means an expression of our own ignorance. It may be taken for granted, that those who estimate most highly the Creator's works, even the humblest, are those who investigate them most and know them best.

Snails and slugs, especially the former, have few personal attractions for strangers, yet they improve upon acquaintance; and we venture to think that 
whoever will take upon himself the task of investigating them, comprehending their history, and unveiling the mysteries of their existence, will ultimately cease to despise them, and even become their champions.

Slugs are not all alike. The little Grey Slug, so common in gardens, is very different from the two kinds usually found in woods. One of these is a large, black creature, which when contracted into a quiescent attitude has longitudinal grooves, or wrinkles, down its body. It is abundant in wet weather, and when in motion is often three or four inches in length, sometimes more. The snail carries his shell on his back, and so does the slug, but in the latter case it is only a small plate imbedded beneath the skin. Like the snail, the slug has four tentacles, called horns by juveniles, which are retractile, and two of them have eyes at their extremities. The natural food of the black slug is green vegetables, and of these it will consume a considerable quantity; hence all cultivators, whether farmers or gardeners, treat them with slight respect.

The other wood slug is sometimes called the Tree Slug, because it is usually found under decayed wood, on which it is said to subsist. It much more nearly resembles the common garden slug, is of a tawnygrey colour, and is narrowed towards the tail. These are the only two common slugs that we are privileged to mention, and these are by no means confined to. woods, whilst others resort by preference to gardens, yet are by no means rare in woods. It requires some little practical knowledge to distinguish the different 
kinds of grey slugs from each other, but this is soon acquired. Snails and slugs should be sought early in the morning whilst the grass is still wet with dew, or after a shower.

The ancient Romans, and some modern nations, held the larger snails in esteem as a great delicacy. They fattened them for the table until they are said to have attained an enormous size. The largest British snail, called the Apple Snail, ${ }^{1}$ is reported to have been a great favourite with the Romans. Some assert that it was brought to this country first by the Roman conquerors, and is only now found in the south, where the shells are discov-

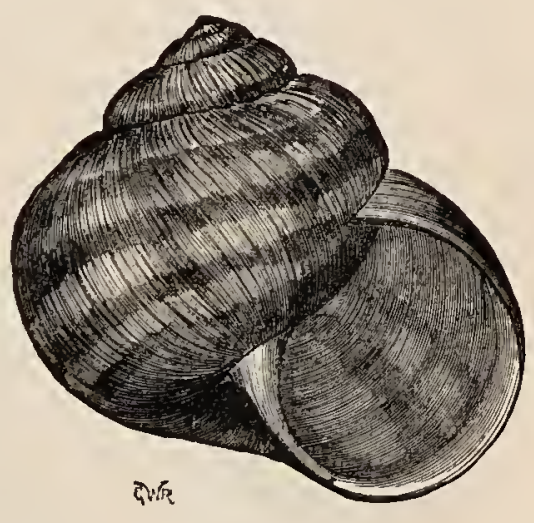

APPLE SNAIL. ered buried in the vicinity of old Roman encampments. Others say that Sir Kenelm Digby introduced them for medicinal purposes. Others, again, that they were brought to Albury, in Surrey, by Mr. Howard, in the sixteenth century. Whichever account be true, it is admitted that they are not indigenous, and even now are only found in chalky districts. Several Continental nations retain snails as a fashionable delicacy. In France

1 Helix pomatia. 
they abound in the vineyards, and are consumed regularly in the restaurants of Paris. The proprietor of one snailery near Dijon is affirmed to clear annually three hundred pounds by his snails. In Switzerland there are established gardens for their cultivation. In Austria and some parts of Italy they are consumed regularly as a matter of course. About sixty thousand pounds of snails are annually exported from the island of Crete for consumption. The taste for this delicacy has also extended to North America. That they were eaten in Spain is evident from a picture by Murillo, in the collection of the Duke of Devonshire, of a beggar boy eating a snail-pie. A writer, passing through the markets of Rome in March, states that he saw exposed for sale "baskets of frogs and shell snails; these were crawling about,
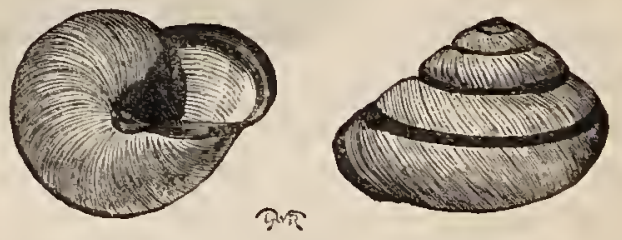

WOOD SNAIL.

and were pushed back by the boys." Why may these not be as good food as the sea-snails, called whelks and periwinkles, which are consumed in enormous quantities, even in England, where the land-snail is despised ?

If it should be conceded that living snails are not the most agreeable creatures to collect and study, the same objection will not hold against their shells; 
and therefore we may excuse ourselves for enumerating some "land-shells," which should be sought in woodlands.

As we have commenced with the large apple snail, we will proceed first with the snails which have a shell similar in form, but considerably smaller. The common garden snail may be omitted; but we have a still smaller snail, scarcely an inch in diameter, often less, of a brown colour, mottled, and marked by a single band, with a white lip, found in moist woods. It is sometimes called the Orchard Snail. ${ }^{\text {I }}$
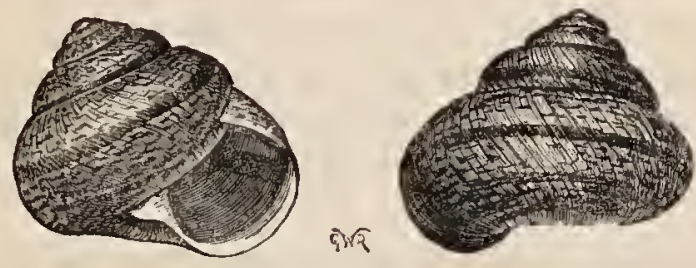

ORCHARD SNAIL.

The Wood Snail ${ }^{2}$ is very variable in colour, often yellow, with a brown band running through the spiral, but with a dark brown lip. A less common and smaller snail has often several bands, but sometimes none. ${ }^{3}$ It may be distinguished by having the lip white. These two shells may be confounded by the novice unless the different colour of the lip be regarded. Both may also be found in hedgerows, and we pity the taste of those who!fail to

1 Helix arbustorum.

3 Helix hortensis.

2 Helix nenoralis. 
recognize the beauty of their form and colouring, which latter has at times a delicate tinge of pink or peach blossom.

Still smaller, less conspicuous, of a horny-brown colour, sometimes hairy, sometimes silky, and sometimes smooth, is the Bristly Snail, ${ }^{1}$ scarcely more than a quarter of an inch in diameter. It must be sought under stones, climbing up herbaceous plants, or amongst leaves.

We might name several other small shells with a somewhat similar contour which are to be found amongst fallen leaves or amongst grass. The most abundant of these is a much more flattened shell than any yet enumerated, of a rufous colour, but most readily distinguished by deep radiating lines. ${ }^{2}$ It is a shell which when once seen can never be mistaken.

Hitherto the shells we have named may be characterized as shorter from the apex of the spiral to the mouth than across at right-angles to it, or about equal in length, whilst those remaining to be noticed are longer in the direction of the spiral than their broadest diameter. One of these is found amongst leaves and upon trunks; it is of a brownish horn-colour, but the animal has a singular habit of rolling its shell in mud, apparently to render it less easy of detection, so that it needs a practised eye to find it, for the coating of mud on the shell closely resembles the bark.

Some small shells are named $P u p a$, because of their resemblance in form to the pupæ of certain

'Helix hisfida.

${ }^{2}$ Helix rotundata. 
insects. The most common of these has a chocolatecoloured shell, with a white lip, and a single tooth at the mouth. ${ }^{1}$ It is a very minute shell, scarce more than one-eighth of an inch long, and half as thick, found amongst leaves and in the fissures of oak bark, often clustered together in considerable numbers.

The last group of shells with which we need trouble our reader are termed in science Clausilia, because the throat of the shell is closed over the retreating animal by a palate, or kind of lid, called a clausium, which is thus described by Gray :- "It consists of a spirally-twisted shelly plate, inclosed in the last whorl of the shell. When the animal is retracted within its shell this shelly plate nearly covers the aperture at a little distance within the mouth, and coming in contact with a transverse plait on the outer lip, leaves only a small canal formed between the outer plait and the posterior angle of the mouth, and sometimes an elongated longitudinal plait on the inner lip. When the animal wishes to protrude itself, it pushes the plate on one side into a groove, situated between the inner plait and the columella, where it is detained by the pressure of the bociy of the animal, leaving the aperture free; and when the animal withdraws itself, the plate springs forward by the elasticity of the pedicel, and closes the aperture."

The first of these is the largest, often three-quarters of an inch long, found amongst decaying beech-leaves, especially in the south. ${ }^{3}$ It is generally of a brownish

1 Bulimus obscurus.

${ }^{3}$ Clausilia laminata.

2 Pupa umbilicata. 
colour, and the spiral consists of ten whorls. In form it is not unlike the buds of the beech-tree, on the trunks of which it is also sometimes found.

Another is less common, being confined chiefly to chalky districts, inhabiting woods and hedges, and is of a dark greyish-brown colour. ${ }^{1}$ It consists of ten or twelve whorls in the spiral, is rather smaller than the last, and is marked with regular longitudinal striæ or lines.

There are other small shells found in the woodlands, but to describe them we must enter into too minute detail, and should our woodland companion have so far overcome his repugnance to snails as to desire their better acquaintance, he will experience no difficulty in obtaining a small handbook, which will teach him better than we can hope to do with so wide a field to scamper over, and thus make good our omissions. Those who would find the small and delicate shells, the tenants of which inhabit dead leaves and moss, must not be afraid to go down upon their knees in the wood, and search diligently if they would be successful.

It may be desirable to add a hint or two on manipulation. When a trip has been successful, and a number of living snails collected and brought home, they should at once be thrown into boiling water, in order to kill the animal and preserve the brightness of the shells. They should then be at once taken out of the hot, and thrown into cold water. The dead animals may then easily be turned out by means

\section{Clàusilia biplicata.}


of a needle or a pin, in the same way that periwinkles are treated for a similar purpose. The shells may be preserved, with a little cotton-wool to keep them from shaking, in small pill-boxes, or glued down upon cardboard.

There has never been much that is romantic associated with snails, neither have they been great favourites with poets. Nevertheless, in the Eastern Counties, where they are called "Dodmans," we have seen children holding them in their fingers, chanting to them meanwhile as prognosticators of the weather-

Dodman, dodman, pull out your horn

And show 'twill be a good day i' the morn.

In addition to this, we read of snails being used as a kind of love divination, when they were set to crawl on the hearth, and were thought to mark in the ashes the initials of the lover's name. As these divinations were usually associated with some particular day, so the snail divination was only effectual when performed on May-day. Gay refers to the practice in the followng lines :-

Last May-day fair I search'd to find a snail, That might my secret lover's name reveal : Upon a gooseberry-bush a snail I found, For always snails near sweetest fruit abound. I seized the vermin; home I quickly sped, And on the hearth the mill-white embers spread: Slow crawled the snail, and, if I right can spell, In the soft ashes marked a curious L. Oh, may this wondrous omen lucky prove ! For $\mathrm{L}$ is found in Lubberkin and Love. 


\section{CHAPTER XVII.}

\section{GALLS AND PARASITES.}

Certain plants are liable to be punctured in their soft parts by insects, for the purpose of depositing their eggs under such conditions that when hatched they may procure food. The violation caused by the insertion of this foreign substance results in the accumulation of an abnormal quantity of tissue in the neighbourhood of the puncture, and a swollen body, termed a "gall," is formed. These galls, therefore, indicate the presence of some insect parasite upon the plant so affected. Some plants are more subject than others to these parasites, as, for instance, the family of Oaks. We have a catalogue of no less than forty-one kinds of gall, which are found upon different species of oak, and this is probably now below the real number known. Amongst herbaceous plants those of the composite family seem to be peculiarly liable to such excrescences.

Not only have we insects parasitic upon plants, but also some plants are parasitic upon others; as the mistletoe and dodder, not to mention many species of fungi.

Then, again, animals are parasitic upon each other: many gall insects have their special parasites; 
bees have their parasites; beetles often carry about with them a parasitic mite; nearly every bird has one or more kind of parasite; quadrupeds have their fleas, and some bipeds, too, unfortunately; whilst even fish and reptiles are not without them. As most intimately connected with our subject, galls deserve more than the rest a special enumeration.

OAK-APPLES.-These galls are known to every schoolboy old enough to put one in his cap on the 29 th of May. They are softer and more spongy in texture than the majority of oak-galls, and are produced plentifully in the spring. A writer in an old book, dated r660, says, "If you take an oak-apple from an oak-tree, and upon the same you shall find a little worm therein, which if it doth flye away it signifies wars; if it creeps, it betokens scarceness of corn; if it runs about, then it foreshows the plague. This is the countryman's astrology, which they have long observed for truth."

Another method which we would recommend to be adopted in preference is to collect some of these galls when they appear to be fully matured, and confine them in a box, or, still better, in a wide-mouthed glass jar, and watch for the insects when they make their escape. Under these conditions they may betoken an addition to the observer's stock of knowledge, provided he is so minded.

There are, of course, general features in which all these gall-fies, called Cynips, ${ }^{1}$ agree with each other, but there will be no better method of cultivating the

1 Cynips torminalis. 
faculty of observation than that of comparing similar insects, one with another, and thus ascertaining wherein they differ, and wherein they agree. It must always be remembered that gall insects are particularly subject to parasitism, and it is very probable that, mixed with the true gall-flies, other insects will be found which from their different general appearance will at once be recognized as intruders.

ArTichoke GaLis, so called because they bear a miniature resemblance to the scaly calyx of the artichoke, are transformed buds, which are stunted and rendered abortive by the puncture of an insect, and thus converted into a kind of scaly gall. These galls are consequently produced upon the young twigs, and remain persistent upon the trees even till the winter. If they are cut through the centre, the grub will be found inclosed within the cell. So common are they that it is almost certain that many specimens may be collected in any oak wood, on the young undergrowth where the oak is coppiced.

Another kind of gall has been found on the young twigs of oak, which are presumably caused by an earlier puncture of the buds than the preceding, and by a different insect. In this instance the exterior of the gall does not become scaly, but they retain the appearance of swollen buds, and might be mistaken for such, only that their growth proceeds no further, so that they never attain one-fourth of the diameter of the artichoke galls. These are not so readily distinguished as the above, from their smaller size and their resemblance to buds, neither are they so common. They are, of course, produced by a different insect, as 
the galls of the same insect are always of the same character.

Common Oak Galls were at first called Devonshire Galls, because they were first observed upon oaks in Devonshire, but have since spread all over the kingdom. They are very different from the soft, round galls of the leaves, being almost as hard as bullets, but differing from the commercial Turkey galls in being smooth on the surface, and more resembling the inferior "white galls" of trade. These galls are either single, or two or three together, or in dense clusters on the young branches of oak, and are so persistent that they will still be

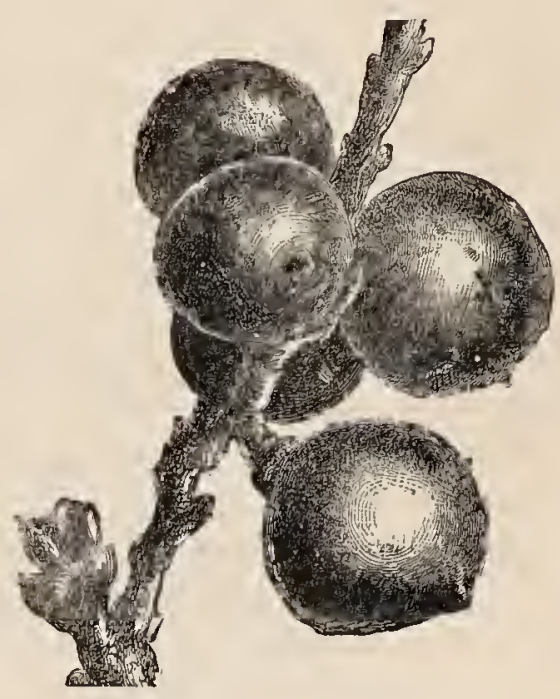

OAK GALLS. seen adhering to the tree when the leaves are all gone and the snow covers the ground. It was about twenty-five years ago that these galls were first noticed in the south of England, and until recently we had a specimen which we obtained about 1855 with the greatest difficulty, and at that time regarded as a rare prize. Their ap- 
pearance in Devon was first observed in 1848 and I 849 ; in Somerset in 1854 ; in Gloucester, west of the Severn, in 1855 ; east of the Severn in 1856 ; Worcester, 1857 ; in the neighbourhood of London, 1858; in North Wales, I859; Sussex, I860; Alice Holt Forest, I861; and Cirencester in 1862 . At the present time they may be regarded as almost as common as acorns all over the kingdom. It was prognosticated at the time that if these galls were permitted to spread they would entirely eradicate the oak from the country. Undoubtedly this gall has long been known upon the Continent, as there is an excellent figure of it in Rosel's work on insects, which is dated I750. The insect which produces it is a pretty little fat-bodied fly, which may be easily obtained by collecting a quantity of the galls and keeping them in a wide-mouthed bottle until the insects escape. They belong to the same genus, Cynips, ${ }^{1}$ as do so many other of the gall-fies.

BaLANiForm Galis are produced on the twigs of the common oak in this country, and on the Continent by a little fly, or Cynips, 2 and were so called by Mr. Curtis because they somewhat resembled the barnacles (Balani) found attached to oyster-shells. They yrow in dense masses, or clusters, surrounding the smaller branches, especially near the base; each gall is somewhat conical with an obtuse apex, and when cut transversely will be found to consist of a single chamber, or cell, containing the larva of the fly. We have met with similar galls on the branches of other 
trees and shrubs, but unfortunately not until after the insects had escaped. Doubtless they were produced by a similar fly.

OAK-Roo' GaLls. - Irregular excrescences, often as large as the fist, at the root of oaks, are a kind of gall produced by another species of Cynips. ${ }^{1}$ These may be easily mistaken for mere woody expansions or gouty swellings, without suspicion of insect work, but if they are cut into with a strong knife, their real character will soon be discovered, with the cells, and probably the larvæ inclosed within them. These excrescences are by no means uncommon, although they are rather difficult to remove, as they grow upon the thick roots, and are almost as hard as the timber itself. Another kind of gall, consisting of single cells, has been once or twice observed at the extremities of the rootlets of oak.

OAK Spangles. - Two kinds of flat discoid galls are very commonly produced on the under surface of oak-leares. One of these, called Oak Spangles, consists of a small lentil-shaped body, thickest in the middle, and attached beneath by a small point like the shank of a button. The upper surface of these galls is sprinkled with tufts of small hairs. It is often supposed that these are fungi by persons who are unacquainted with those polymorphic plants; but they are in reality the work of insects. Leaves bearing these galls fall from the tree in autumn, and lie on the ground through the winter, during which time the inclosed insect is being developed. If decaying oak-

1 Cynips radicis. 
leaves are turned over in spring, these galls will be found still adhering, but more swollen than in the preceding autumn. If then collected and placed in a wide-mouthed bottle, it is almost certain that in a few days the little imprisoned insects ${ }^{1}$ will make their escape from the galls, and be seen moving about in the bottle. We have collected them at the end of February, and in a warm room the lively little flies have been seen moving about in the bottle within a week. Any one who finds the male insect will do good service, for the males of these flies are by no means satisfactorily known, and some are not known at all.

Butron Galls are less in diameter than the Spangles, with the margin thickened so as to form a kind of shallow cup; the surface is silky, with closepressed fibrils, and it is attached to the leaf by the centre, in the same manner as the spangles. It is caused and inhabited by a different insect, although often found in company with the spangles. The name of the insect said to produce these galls is Neurobius Réaumuri. Hitherto we have not succeeded in rearing the insect from the button galls, and we have heard the same complaint from others. Probably they have not yet been collected in proper condition, or not been preserved with sufficient attention to the maintenance of a proper amount of moisture.

Another saucer-shaped gall has been described as occurring on oak-leaves, but this we do not remember to have met with. This is said to be larger than the button galls, and to have been found in November. 
It was recorded in the "Gardener's Chronicle" in I 843 (p. 52), and the insect was then named Cynips quercus tiara.

There is still another gall occurring on the underside of oak-leaves, which is globose, and often as large as a cherry, brightly coloured, and quite smooth. It is by no means an uncommon gall, and in most cases seems to arise from a puncture of the midrib. The insect which inhabits it is a Cynips, but that is often accompanied by one, if not two kinds of parasites. $^{l}$ It is a curious fact that these gall in-

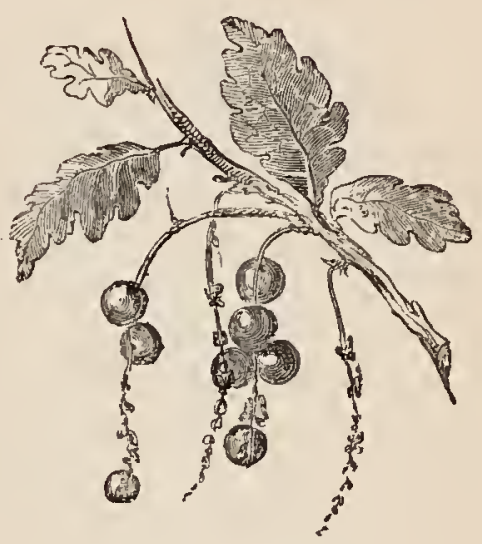

CURRANT GALL. sects, which are parasites upon the oak, have often other insects which are parasitic upon them.

CURRant OAK-Galls. - Small round galls are not uncommon in spring on the flower-stalks of the oak They are nearly of the size and resemble red-currants, the more so when several of them are growing together on the same peduncle. The Cynips, ${ }^{2}$ or little fly which produces this gall, has also two parasites, ${ }^{3}$ to the attacks of one or both of which it is subjected.

1 Decatoma Cooperi and a species of Callimone.

${ }^{2}$ Cynips pedunculi.

3 Callimone flavipes and Platymesopus tibialis. 
WOOLLy OAK-Gall. - Another gall is found on the flower-stalk of the oak. It occurs on the male catkins in May, forming a mass as large as a horse-chestnut, of a whitish colour, and woolly, something like a tuft of sheep's wool. It has only rarely been found in Britain, but has long been known on the Continent. The little fly which causes it belongs to the same genus, but is a different species from the foregoing. ${ }^{1}$

This does not exhaust the list of galls produced by insects on oaks of different species, but it includes the majority of those found in Britain. The Turkey Galls, as they are called, are never found here, the particular species of oak is not generally cultivated, and even the Turkey oak, which is not uncommon in our parks, does not produce here the Knoppern galls which are common upon it in Eastern Europe. So few entomologists devote themselves to the special study of galls that it is quite possible we may have others which have hitherto escaped notice. If galls are collected before the larwæ are well fed, the galls become dry and shrivel, the maggots die, and consequently the insect cannot be determined.

Elm Galls.-Rarely galls are found upon the branches of the elm, at the apex of the short lateral twigs, and these attain a size from that of a walnut to a large apple. These are hollow, and contain a considerable quantity of fluid. They inclose an entire colony of insects, of the aphis or plant-louse tribe, and should more properly be termed cases than galls, although they originate from a similar cause. The insects are said to be a species of Eriosoma, and the galls which they produce are common in Italy and 
France, where the liquid which they contain is called eau de l'Orme, and is recommended as a wash for wounds, contusions, and sore eyes. In the autumn, when the galls become dry, the residue has the form of a yellow balsam, when it is said to be employed for diseases of the chest.

ELII-Roor GALLS.-Other galls are found upon the roots of the elm, varying in size from that of a pea to a walnut, uniting together in irregular masses, and having a rough, reticulated exterior, so as to resemble truffles. These inclose insects of the Cynips ${ }^{1}$ kind, but both sexes are without wings. They are not common in Britain.

SPruce-Cone Galls. - The young twigs of spruce are liable to assume the appearance of small fircones, with part of a branch springing from the top, but they are in reality a peculiar form of gall, caused by aphides, ${ }^{2}$ and inclosing quite a colony. These galls are about an inch in length, and half as much in diameter. From their resemblance to small cones these curious malformations are liable to be overlooked.

Poplar-LEAF Gall.--It is a very common circumstance to find the petioles, or leaf-stalks of the poplar, especially of the common black poplar, swollen in a gouty manner into an oval or irregular-shaped gall, which occasionally occurs on the midrib of the leaf itself. This gall is not much larger than a pea, but it usually contains a large number of aphides ${ }^{3}$ without wings, together with four or five winged ones. As in the case of the elm galls, these are hollow; indeed, the structure of the galls, or cases, which are produced by aphides, is quite different from that

${ }^{1}$ Cynips aptera. ${ }^{2}$ Adelges abietis. ${ }^{3}$ Eriosona bursaria. 
produced by Cynips. Whereas the former inclose quite a colony, the latter only one or two.

Thistle Galls. - Of the many galls, or cases, found on herbaceous plants, one of the most common and most interesting is that which occurs on thistles. The stem is swollen in an unnatural manner for an inch or more to two or three times its proper size; and this swollen part contains several cells, in which the grubs of a fly may be found. In the spring following the autumn in which the galls are formed the insects make their escape about May or June as a pretty little two-winged fly. ${ }^{1}$ In former days these galls were considered an unfailing remedy against certain diseases, being carried about by the patients in little bags. It was believed that they were efficacious against the most powerful fevers. The insect which causes this gall is often accompanied by a Hymenopterous parasite.

The ground ivy, ragwort, tansy, thyme, speedwell, betony, burdock, mugwort, tansy, and other herbaceous plants are subject to galls. The Bedeguar, or Robin's pincushion, on the wild rose, is too well known to need description. Some are on the leaves, some on the stems, some on the roots, and each has a history which is worth the trouble of reading. But our end has come, and with it one more appeal for the studies introduced. Let this be spoken by one who has gone to his rest, but who never tired in bidding all to "look through Nature up to Nature's God."

"Believe me," he says," "you need not go far to

1 Mrusca (Tephritis) cardui. $\quad 2$ Kingsley's 'Miscellanies.' 
find more than you will ever understand. An hour's summer walk in the company of some one who knows what to look for, and how to look for it, by the side of one of those stagnant dykes in the meadows below, would furnish you with subjects for a month's investigation, in the form of plants, shells, and animalcules, on each of which a whole volume might be written. And even at this seemingly dead season of the year fancy not that nature is dead -not even that she sleeps awhile. Every leaf which drops from the bough, to return again into its gases and its dust, is working out chemical problems which have puzzled a Boyle and a Lavoisier, and about which a Liebig and a Faraday will now tell you that they have but some dim guess, and that they stand upon the threshold of knowledge, like (as Newton said of himself) children gathering a few pebbles upon the shore of an illimitable sea. In every woodland, too, innumerable fungi are at work, raising from the lower soil rich substances, which strewed on the surface by quick decay will form food for plants higher than themselves; while they, by their variety and beauty, both of form and colour, might well form studies for any painter, and, by the obscure laws of their reproduction, studies for any philosopher. Why, there is not a heap of dead leaves among which by picking it through carefully you might not find some twenty species of delicate and elegant land shells; hardly a tree at which, among the moss and mould, you might not find the chrysalides of beautiful moths, where caterpillars have crawled down the trunk in autumn, to lie there self-buried, and die to live again next spring in a new and fairer shape. And if you cannot 
reach even there, go to the water-butt in the nearest yard, and there, in one pinch of green scum, in one spoonful of water, behold a whole 'Divina Commedia' of living forms, more fantastic a thousand times than those with which Dante peopled his unseen world; and then feel, as you should feel, abashed at the ignorance and weakness of mortal man; abashed still more at that rash conceit of his, which makes him fancy himself the measure of all things; and say with me: 'O Lord, Thy works are manifold, Thy ways are very deep. In wisdom hast Thou made them all, the earth is full of Thy riches. Thou openest Thine hand, and fillest all things living with plenteousness; they continue this day according to Thine ordinance, for all things serve Thee. Thou hast made them fast for ever and ever, Thou hast given them a law which shall not be broken. Let them praise the name of the Lord; for He spake the word and they were made, He commanded, and they were created!'"

THE END. 


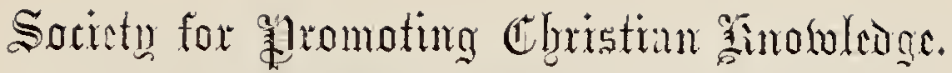

\section{NATURAL HISTORY RAMBLES,}

Fcap. Svo., Cloth boards, 2s. 6d. each.

\section{LANE AND FIELD.}

By the Rev. J. G. WooD, M.A., Author of "Homes without Hands," ic., \&c.

\section{LAKES AND RIVERS.}

Dy C. O. Groom Napier, F.G.S., Author of "The Food, Use, and the Beauty of British Birds," \&rc., \&rc.

\section{MOUNTAIN AND MOOR.}

By J. E. Taylor, Editor of "Science-Gossip."

\section{THE SEA-SH O R E.}

By Professor P. Martin Duncan, M.B. (London), F.R.S., IIonorary Fellow of King's College, London.

\section{U N D ERGROU N D.}

By J. E. TAylor, Editor of "Science-Gossip."

\section{WOODLANDS.}

\author{
By M. C. Cooke, M.A., LL.D.
}


Beauty in Common Things. Illustrated by 12 Drawings from Nature, by Mrs. J. W. Whymper, and printed in Colours, with descriptions by the Author of "Life Underground," \&c. 4to. ............Cloth boards io 6

Botanical Rambles. By the late Rev. C. A. Jonns, B.A., F.L.S. With illustrations and woodcuts. Royal I 6mo..........................................Cloth boards

Flowers of the Field. By the late Rev. C. A. Jouss, B.A., F.L.S. With numerous woodcuts. Fcap. Svo....................................... Cloth boarts

Wild Flowers. By Anne Pratt, Author of "Our Native Songsters," \&c. With 192 coloured plates, in two volumes. I6mo. ..........................Cloth boards I6 0

Forest Trees (The) of Great Britain. By the Rev. C. A. Jorns, B. A., F.L.S. New Edition. With I5O woodcuts. Post Svo. ............ Cloth boards

Natural History of the Bible (The). By the Rev.

Canon TRIstrair, Author of "The Land of Israel," \&.c.

With numerous illustrations. Crown Svo. Clotk boards

Animal Creation (The). A popular Introduction to Zoology. By Thomas Rruier Jones, F.R.S. With $48 S$ woodcuts. Post Svo. ............... Cloth boards

Lessons from the Animal World. By Charles and SARAII TOMLINSON. With 162 woodcuts, in two volumes. Fcap. Svo. .................... Cloth boarts

Birds' Nests and Eggrs. With 22 coloured plates of Eggss. Square I6mo. ................... Cloth board's

British Birds in thcir IIaunts. By the late Rev. C. A. Johns, B.A., F.L.S. With I9o engravings by Wolf and Whymper. I'ost Sro. ......... Cloth boards io o 
British Animals. With r 2 coloured plates. r6mo.

Birds of the Sea-shore. With $\mathrm{r} 2$ coloured plates. $16 \mathrm{mo}$.

Evenings at the Microscope; or, Researches among the Minuter Organs and Forms of Animal Life. By Philip Henry Gosse, F.R.S. A new Edition revised and annotated. With 112 woodcuts. Post Svo. Cloth boards

Familiar History of British Fishes. By Frank BUCKLand, Inspector of Salmon Fisheries for England and Wales. With a Frontispiece and I 34 woodcuts. Crown 8vo. ...................................... Cloth boards

Natural History (Illustrated Sketches of); consisting of Descriptions and Engravings of Animals. With numerous woodcuts, in 2 vols. Fcap. 8vo.

Series I. and II. .................. Cloth boards, cach Vol.

Our Natize Songsters. By Anne PRATT, Author of "Wild Flowers." With 72 coloured plates. $16 \mathrm{mn}$. Cloth boards \& 0

Selborne (The Natural History of). By the Rev. Gilbert White. With Frontispiece, Map, and 50 woodcuts. Post 8 vo. ............................Cloth boarls

Ocean (The). By Philip Henry Gosse, F.R.S,. Author of "Evenings at the Microscope." With 5 I illustrations and woodcuts. Post 8vo. Cloth boarts 46

Dezu-drop and the Mist (The): an Account of the Phenomena and Properties of Atmospheric Vapour in various parts of the World. By CIIARLES TOMLINSON, F.C.S.S. With woodcuts and diagrams. Fcap. 8vo. Clot/2 boards 26 
Frozen Stream (The): an Account of the Formation and Properties of Ice in various parts of the World. By Charles Tomlinson. With woodcuts and diagrams. Fcap. Svo. ..........................Cloth boards

$$
\text { grams. Fcap. Svo. }
$$

Rain-Cloud and Snozu-Storm: an Account of the Nature, Formation, Properties, Dangers, and Uses of Rain and Snow. By Charles Tomlinsox. With numerous woodcuts and diagrans. Fcap. Sro. Cloth boarts

Temfest (The): an Account of the Origin and Phenomena of Wind in various parts of the World. By Charles Tomlinson. With numerous woodcuts and diagrams. Fcap. Svo...........................Cloth boards

Thunder-Storm (The): an Account of the Properties of Lightning and of Atmospheric Electricity in various parts of the World. By Charles Tomlinsox. With numerous woodcuts and diagrams. Fcap. Svo. Cloth boards

Wnter in the Artic Regions and Summer in the Antarctic Regions. By Charles Tomlinson. With two maps, and several illustrations and woodcuts.

Crown Svo. ................................... Cloth bonrth

\section{国epositorics:}

77, GT. QUEEN STREET, LIACOLN'S INN FIELDS, W.C.; 4, ROYAL EXCHANGE, E.C. ; \& 48, PICCADILLY, W.,

\section{LONDON.}





\section{Date Due}

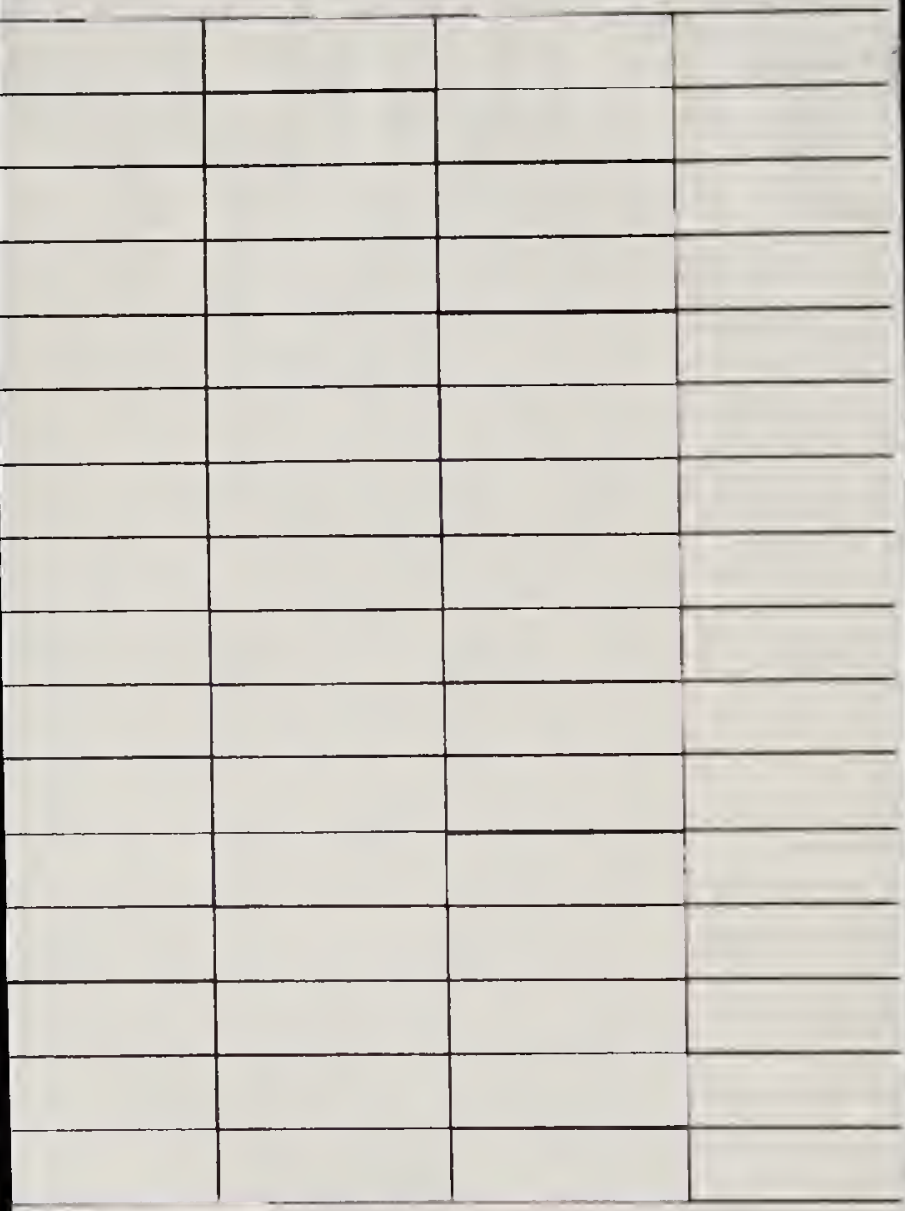




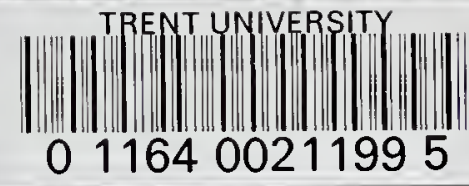

QH45 . C66

Cooke, Mordecai Cubitt.

The woodlands.

DATE

ISSUED TO26 C65\%

260658 

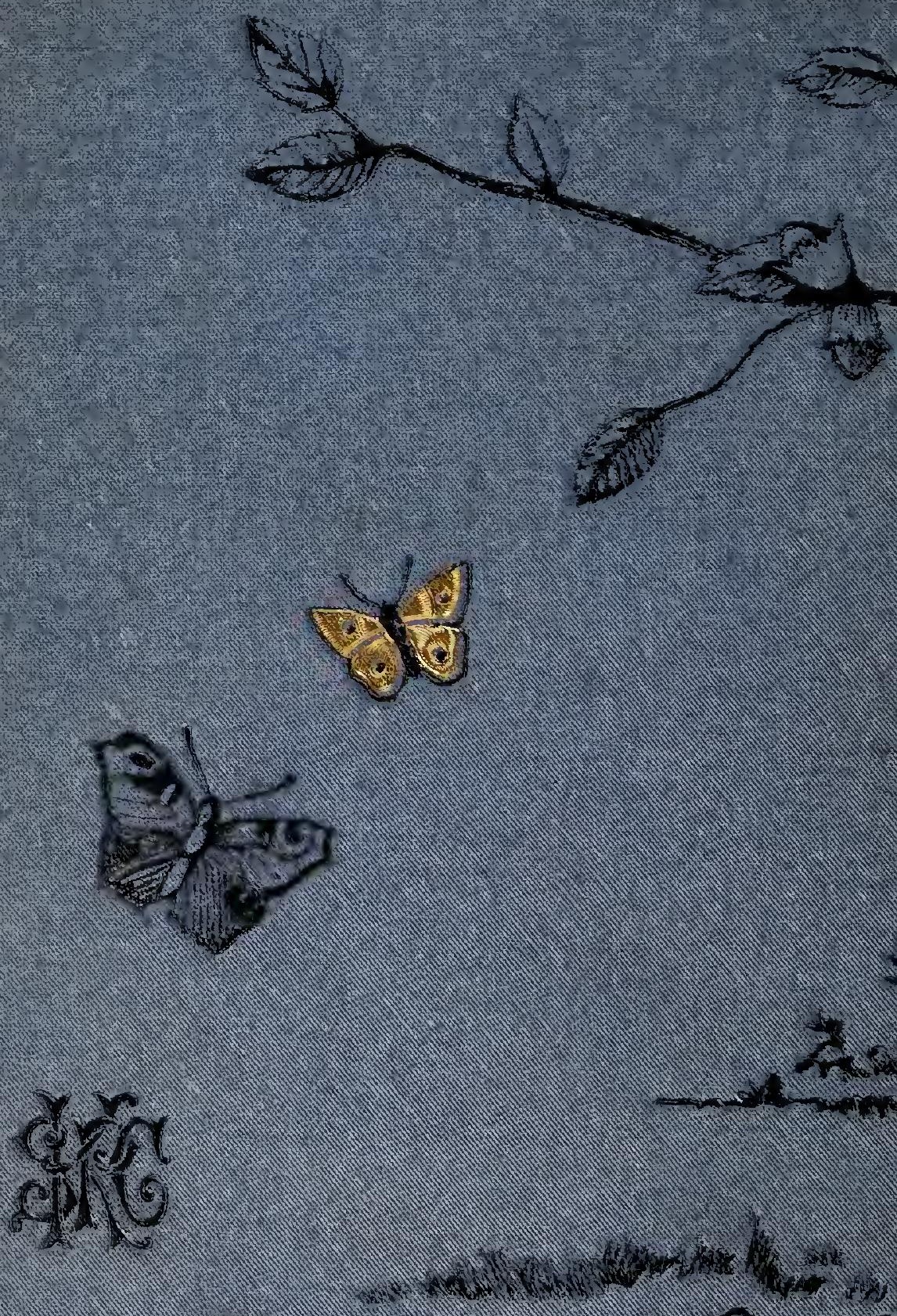